\title{
Performance Testing of Radiobioassay Laboratories: In Vivo Measurements, Final Report
}

\author{
J. A. MacLellan \\ R. J. Traub \\ P. C. Olsen
}

J. M. Selby, Program Manger

April 1990

Prepared for the U.S. Department of Energy under Contract DE-AC06-76RLO 1830

Pacific Northwest Laboratory

Operated for the U.S. Department of Energy by Battelle Memorial Institute 


\title{
DISCLAIMER
}

This report was prepared as an account of work sponsored by an agency of the United States Government. Neither the United States Government nor any agency thereof, nor Battelle Mernorial Institute, nor any of their employees, makes any warranty, expressed or implied, or assumes any legal liabillty or responsibility for the accuracy, completeness, or usefulness of any information, apparatus, product, or process disclosed, or represents that its use would not infringe privately owned rights. Reference herein to any specific commercial product, process, or service by trade name, trademark, manufacturer, or otherwise, does not necessarily constitute or imply its endorsement, recommendation, or favoring by the United States Government of any agency thereof, or Battelle Memorial Institute. The views and opinions of authors expressed herein do not necessarily state or reflect those of the United States Government or any agency thereot.

\author{
PACIFIC NORTHWEST LABORATORY \\ operated by \\ BATTELLE MEMORIAL INSTITUTE \\ for the \\ UNITED STATES DEPARTMENT OF ENERGY \\ under Contract DE-ACO6-76RLO 1830
}

Pristed in the United States of America

Availabie to DOE and DOE contractors from the

Otfice of Scientific and Technicai Information, P.O. Box 62, Oak Ridge, TN 37831; prices available from (615) 576-8401. FTS 626-8401.

Available to the public from the National Technical Information Service,

U.S. Department of Comrnerce, 5285 Port Royal Rd., Springfield, VA 22161.

NTIS Price Codes, Microfiche A0T

Printed Copy

\begin{tabular}{cr}
\hline Price Code & Page Range \\
\hline A02 & $1-10$ \\
A03 & $11-50$ \\
A04 & $51-75$ \\
A05 & $76-100$ \\
A06 & $101-125$ \\
A07 & $126-150$ \\
A08 & $151-175$ \\
A09 & $176-200$ \\
A10 & $201-225$ \\
A11 & $226-250$ \\
A12 & $251-275$ \\
A13 & $276-300$ \\
A14 & $301-325$
\end{tabular}

\begin{tabular}{cc}
\hline Price Code & Page Range \\
\hline A15 & $326-350$ \\
A16 & $351-375$ \\
A17 & $376-400$ \\
A18 & $401-425$ \\
A19 & $426-450$ \\
A20 & $451-475$ \\
A21 & $476-500$ \\
A22 & $501-525$ \\
A23 & $526-550$ \\
A24 & $551-575$ \\
A25 & $576-600$ \\
A99 & $601-U p$
\end{tabular}


PNL -7307

UC -607

PERFORMANCE TESTING OF RADIOBIOASSAY LABORATORIES: IN VIVO MEASUREMENTS, FINAL REPORT

J. A. MacLellan

R. J. Traub

P. C. Olsen

J. M. Selby, Progran Manager

April 1990

Prepared for

the U.S. Department of Energy

under Contract DE-AC06-76RLO 1830

Pacific Northwest Laboratory

Richland, Washington 99352 


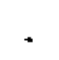

.

.

$+$

.

,

- 


\section{ABSTRACT}

A study of two rounds of in vivo laboratory performance testing was undertaken by Pacific Northwest Laboratory (PNL) to determine the appropriateness of the in vivo performance criteria of draft American National Standards Institute (ANSI) standard ANSI N13.30, "Performance Criteria for Bioassay." The draft standard provides guidance to in vivo counting facilities regarding the sensitivity, precision, and accuracy of measurements for certain categories of commonly assayed radionuclides and critical regions of the body.

This report concludes the testing program by presenting the results of the Round Two testing. The previous pilot round of testing was reported by Robinson et al. (1986). The two rounds of testing are compared in this report, which cites the gains made over the previous study.

Testing involved two types of measurements: chest counting for radionuclide detection in the lung, and whole body counting for detection of uniformly distributed material. Each type of measurement was further divided into radionuclide categories as defined in the draft standard.

The appropriateness of the draft standard criteria by measuring a laboratory's ability to attain them were judged by the results of both Round One and Round Two testing. The testing determined that performance criteria are set at attainable levels, and the majority of in vivo monitoring facilities passed the criteria when complete results were submitted. The single minimum detectable amount (MDA) calculation was determined to be unsatisfactory for use with an accreditation program because; 1) reporting a proper value of $\left(s_{b}\right)$ for appropriate blanks was not possible for some automated counting systems; 2) the MDA statistic must be tailored to the laboratory's particular system of measurement and data analysis in order for proper baseline determinations to be made; and 3) each laboratory's quality control data should be used in lieu of the small set of test background measurements to identify important blank spectra characteristics that will affect the MDA calculation. 


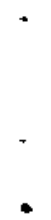

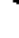
- 
This report concludes a series of documents based on a performance testing program that was developed for U.S. Department of Energy (DOE) bioassay testing laboratories (and other radiobioassay testing laboratories that participated) in order to evaluate their performance in analyzing and reporting in vivo radioactivity concentrations. The work was based on the DOE Laboratory Accreditation Program (DOELAP), whereby laboratories were tested to determine their conformance to the applicable standards in the proposed American National Standards Institute (ANSI) Standard N13.30, "Performance Criteria for Bioassay". (a) A pilot round of testing was performed and reported in 1986. The final (Round Two) testing results are reported here and compared with the pilot testing results of 1986; details of phantom preparation and testing radionuclide solution preparation are included, as is a sumnary of laboratory performance with recommendations for revisions to the draft ANSI N13.30.

of 23 separate facilities originally contacted for the study, 11 of them reported results to the testing program after changes in the scope of the program were concluded. Among these 11 facilities, several had multiple analys is laboratories or systems to test, which raised the total number of responses to 27 participating in one or more testing category.

One of the most critical elements determined by the testing program was the choice of valid formulae used to determine the minimum detectable amount (MDA) of a particular counting system. The results of Round Two testing have required the use of several methods of determining the MDA of a facility, based on the quality of the reported background and testing blank data that were furnished.

Results indicate that for the MDA criteria more than $50 \%$ of the reporting laboratories did not include information on blank results, and with few exceptions it was not possible to determine their MDAs in proper accordance with the draft standard. Thus, they were not included in the passing

(a) Copies of the published draft are available from the Office of the Health Physics Society Executive Secretary, 800 Westpark Drive, Suite 400, MCLean, VA 22101. 
statistic. It was determined that a calculation of the MDA based on results of non-blank samples gave an imprecise measure of each laboratories' performance capability. For those laboratories that had an MDA calculated in accordance with the draft standard there was only an $8 \%$ failure rate overall.

Bias and precision measurement results were dependent on the radionuclide and interferences present. Cerium-144 lung counting results showed improved performance when compared with the pilot round whole body counting of ${ }^{144} \mathrm{Ce}$, but overall only 7 of 21 facilities passed all of the criteria. Similar results were obtained for the second fission/activiation product testing nuclide, ${ }^{54} \mathrm{Mn}$, although a fair amount of respondents misidentified the radionuclide. For the uranium and $238 \mathrm{Pu}$ lung counting categories, all three facilities that sent results passed the precision criteria with a wide margin of success. However, $50 \%$ of $238 \mathrm{Pu}$ results exceeded the bias performance criterion. For $238_{U}$ all laboratories passed the bias criterion. A potential fault in the realistic phantom could have caused the low bias results in plutonium lung counting.

In the whole body counting categories, only 4 of 11 facilities passed all of the criteria for ${ }^{137} \mathrm{Cs}$, although the failure in achieving the MDA was only 9\% as compared with 38\% in the previous pilot test. Again, not reporting the blank counting data was the largest cause of not passing the MOA criterion. For ${ }^{134} \mathrm{Cs}$, only 2 of 10 facilities passed all of the performance criteria.

A large diversity in the performance of bioassay laboratories is still evident, in spite of the fact that there have been several gains since the previous testing round. Lung counting for fission products improved by a factor of about 3, and the results of transuranic and natural uranium counting continued to be very good. Gains were not made in whole body fission-product counting, but the difference in the radionuclide matrix of the Round Two test phantoms and the phantoms used in the pilot testing made this comparison less valid. The most significant observation of Round Two is the necessity for obtaining actual background and blank counting data from the analysis equipment, because without these data no valid MDA can be calculated. The attempt to use derived background counting data from phantoms with test radionuclides greater than the acceptable minimum detectable amount (AMDA), in lieu of blank counting data that were not submitted, consistently caused failure of the MDA 
criterion. All multi-channel counting systems should have the ability to manually remove count data in specified regions of interest.

Several concepts used in this report differ from the current draft ANSI N13.30. The determination of a confidence interval for the MDA statistic was introduced to characterize random and systematic errors that can cause uncertainty in the MDA estimate. This allowed for a comparison to be made of passing the MDA criterion using the MDA itself or using the lower $5 \%$ bound of the confidence limit of the MDA. The confidence limit of the MDA statistic was based on the use of a chi-square distribution for the standard deviation.

Due to the long duration of the testing program, some of the testing phantoms had radioactively decayed to less than 10 times the AMDA of activity before the testing program was complete. Thus, bias and precision results for some categories could not be evaluated in accordance with the draft standard. Even so, in many instances laboratory performance at activities below the specified AMDA itself was still well within limits. In only a few cases was it possible to conclude from the analyses of the data that a failure of precision or bias was due to excess random counting error from low-activity (less than 10 AMDA) phantoms.

Four reasons for laboratory failure of the MDA performance criterion were noted. Two reasons were due to improper or missing counting data for blank and background spectra. The inability to detect radioactivity at the specified AMDA was noted; and one due to failure to consider the uncertainty in the MDA estimate.

Recormendations from this testing round include: 1) the use of tailored MDA equations, based on the analysis and calculational methods of the procedure evaluated; 2) the use of a laboratory's own quality control data to determine baseline spectra in lieu of the small set of measurements received from performance testing; and 3) the use of procedures for revising the MDA calculation when Poisson statistics are rejected by appropriate statistical testing. 



\section{ACRONYMS}

ALI

AMDA

ANSI

BOMAB

$\mathrm{Br}_{\mathrm{r}}$

DOE

DOELAP

HPS

ICRP

LLNL

MDA

MDC

NCRP

NIST

NRC

PNL

QA

QC

$S_{A}$

$\mathrm{S}_{\mathrm{B}}$

TQ annual limit on intake

acceptable minimum detectable amount

American National Standards Institute

bottle-manikin-absorption (phantom)

relative bias

U.S. Department of Energy

Department of Energy Laboratory Accreditation Program

Health Physics Society

International Commission on Radiological Protection

Lawrence Livermore National Laboratory

minimum detectable amount

minimum detectable count

National Council on Radiation Protection and Measurements

National Institute of Standards and Technology

U.S. Nuclear Regulatory Commission

Pacific Northwest Laboratory

quality assurance

quality control

relative precision (formula $A$ )

relative precision (formula $B$ )

testing quantity 


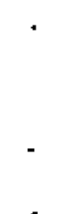




\section{ACKNOWLEDGMENTS}

The authors would like to express their thanks and appreciation to the internal dosimetrists who participated in these studies and the National Institute for Standards and Technology for having provided many of the radionuclide standard solutions that were used in the project. We would also like to acknowledge the skillful assistance of our editor, Susan K. Ennor, and our word processor, Marianna Cross. 


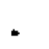




\section{CONTENTS}

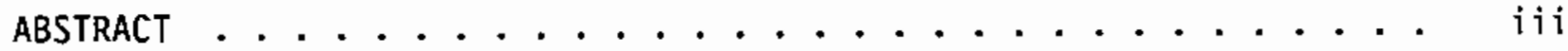

SUMMARY .............................. . . . . . .

ACRONYMS .......................... ix

ACKNOWLEDGMENTS ..................................

INTRODUCTION . . . . . . . . . . . . . . . . . . . . 1

PREPARATION OF DRAFT ANSI N13.30,................ 1

TECHNICAL EVALUATION OF DRAFT ANSI N13.30 . . . . . . . . 3

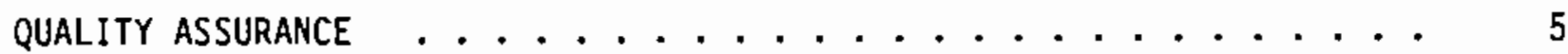

METHODS . . . . . . . . . . . . . . . . . . . . . . 7

LABORATORY PARTICIPATION . . . . . . . . . . . . . . 7

Round One Pilot Study ................ 7

Round Two Testing ................... . . 9

PREPARATION OF IN VIVO PHANTOMS ................. 10

Whole Body Phantom Preparation . . . . . . . . . . 12

Lung Phantom Preparation .............. 14

PHANTOM IDENTIFICATION AND SHIPMENT

TO PARTICIPATING LABORATORIES . . . . . . . . . . . . 20

DATA EVAlUATION . . . . . . . . . . . . . . . . . . . . 21

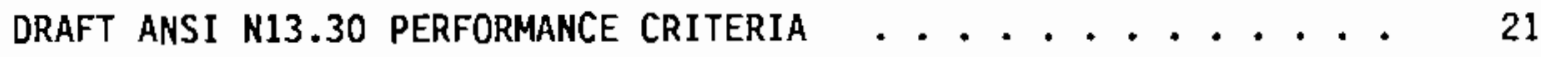

Relative Bias..................... 21

Relative Precision ................. . . . 22

Minimum Detectable Amount . . . . . . . . . . 22

CONFIDENCE INTERVALS FOR THE PERFORMANCE CRITERIA . . . . . . . 24

Confidence Interval for the Estimated
Minimum Detectable Amount .............. 26

Service Laboratory Estimated Minimum
Detectable Anount . . . . . . . . . . . . . 26 
LABORATORY PERFORMANCE SUMMARY . . . . . . . . . . . . 27

CONCLUSIONS AND RECOMAENDATIONS ................ 47

LABORATORY ATTAINMENT OF PERFORMANCE CRITERIA . . . . . . . 47

RECOMMENDED REVISIONS TO DRAFT ANSI N13.30 ......... 50

REFERENCES ............................. 53

APPENDIX A - IN VIVO MEASUREMENTS REPORT FORM . . . . . . . A.1

APPENDIX B - PROPAGATION OF ERROR IN SPIKED IN VIVO PHANTOMS . . . B.1

APPENDIX C - IN VIVO BIOASSAY CDUNTING RESULTS ......... C.1 


\section{FIGURES}

$1238 \mathrm{Pu}$ Bias Statistic $\left(\mathrm{B}_{\mathrm{r}}\right)$ Lung Counting Results . . . . . . . 29

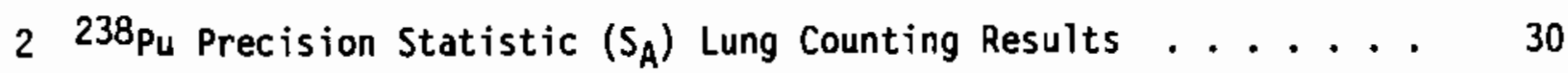

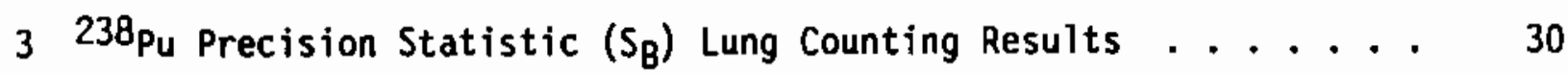

$4238_{\mathrm{U}}$ Bias Statistic $\left(B_{\mathrm{r}}\right)$ Lung Counting Results ......... 31

$5238_{U}$ Precision Statistic $\left(S_{A}\right)$ Lung Counting Results ...... 32

$6238_{U}$ Precision Statistic $\left(S_{B}\right)$ Lung Counting Results ...... 32

$7{ }^{54} M_{n}$ Bias Statistic $\left(B_{r}\right)$ Lung Counting Results ........ 34

$8{ }^{54} M n$ Precision Statistic $\left(S_{A}\right)$ Lung Counting Results ...... 34

$954_{M n}$ Precision Statistic $\left(S_{8}\right)$ Lung Counting Results ...... 35

$10{ }^{144}$ Ce Bias Statistic $\left(B_{r}\right)$ Lung Counting Results ........ 37

$11{ }^{144} \mathrm{Ce}$ Precision Statistic $\left(S_{A}\right)$ Lung Counting Results ...... 37

$12{ }^{144}$ Ce Precision Statistic $\left(S_{B}\right)$ Lung Counting Results ...... 38

$13{ }^{137}$ Cs Bias Statistic $\left(B_{r}\right)$ whole Body Counting Results . . . . . 39

$14{ }^{137} \mathrm{Cs}$ Precision Statistic $\left(S_{A}\right)$ Whole Body Counting Results .... 40

$15{ }^{137}$ Cs Precision Statistic $\left(S_{B}\right)$ Whole Body Counting Results .... 40

$16{ }^{134} \mathrm{Cs}$ Bias Statistic $\left(\mathrm{B}_{\mathrm{r}}\right)$ Whole Body Counting Results ...... 41

$17 \quad{ }^{134} \mathrm{Cs}$ Precision Statistic $\left(S_{A}\right)$ whole Body Counting Results . . . 42

$18{ }^{134}$ Cs Precision Statistic $\left(S_{B}\right)$ Whole Body Counting Results . . . 42 


\section{$\underline{\text { TABLES }}$}

1 Round One Test Radionuclides, Organs, and Activity Ranges for In Vivo Performance Testing ...........

2 Round Two Test Radionuclides, Organs, and Activity Ranges for In Vivo Performance Testing ........... 10

3 Acceptable Minimum Detectable Anounts for Nuclides Used in Round Two Testing ...............

4 Dimensions of Phantom Bottles Representing Human Body Parts ................

5 Total Activity of Test and Interference Radionuclides in the BOMAB whole Body Bottle Phantom ........... 14

6 Round Two Performance Test Lung Activities . . . . . . . . . . 19

7 Student's t Statistic at $90 \%$ Confidence Level . . . . . . . 25

8 Factors for MDA Confidence Interval Estimation ......... 26

9 Sumnary of In Vivo Performance Test Results -

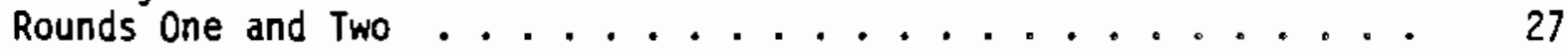

$10238 \mathrm{Pu}$ Lung In Vivo Intercomparison Testing Results ....... 29

$11238_{U}$ Lung In Vivo Intercomparison Testing Results ....... 31

$1254_{M n}$ Lung In Vivo Intercomparison Testing Results ....... 33

$13{ }^{144}$ Ce Lung In Vivo Intercomparison Testing Results ...... 36

$14{ }^{137}$ Cs whole Body In Vivo Intercomparison Testing Results ..... 39

$15{ }^{134}$ Cs whole Body In Vivo Intercomparison Testing Results ..... 41 


\section{INTRODUCTION}

In the early 1980s, the U.S. Department of Energy (DOE) embarked on a process of evaluating and upgrading performance at DOE and DOE contractor facilities to ensure that their measurements of occupational radiation exposure are accurate. DOE's approach has been to encourage the development of performance standards by national consensus standards organizations, to evaluate the feasibility and technical appropriateness of the standards for application in DOE operations, and to develop and implement a routine performance testing program. These steps were completed for personnel dosimetry with the establishment of the Department of Energy Laboratory Accreditation Program (DOELAP) in 1986. DOE is now focusing on programs for radiation protection radiobioassay, internal dosimetry, and instrumentation.

Radiobioassay procedures are used to estimate the amount of radionuclides inside the body. One type of bioassay procedure, in vitro analys is involves measuring radioactivity in samples of body excreta. Another type, in vivo analysis, involves measuring radioactive emissions from the body ( $x$ - or gamma rays) using radiation detectors positioned close to the body. Accurate bioassay measurements are necessary to assess a worker's internal dose following an intake of radioactivity.

Significant differences exist in the techniques and instrumentation used for bioassay. However, any effectively managed bioassay program will be concerned with quality control, so that accurate determinations are made without bias caused by the procedure used in making the measurement.

\section{PREPARATION OF DRAFT ANSI N13.30}

The Health Physics Society (HPS) Working Group 2.5(a) was formed in 1979 to address the concern about accurate measurements. This group prepared the draft American National Standards Institute (ANSI) Standard ANSI N13.30 (ANSI 1989), which defined the criteria for analytical measurement performance of radiobioassay laboratories. The primary concern of the working Group was that bioassay service laboratories, both commercial and institutional, must provide

(a) The current chairman of Health Physics Society Working Group 2.5 is Roscoe Hall, Savannah River Plant, Aiken, SC 29801. 
accurate results for the analyses performed. The following factors may contribute to internal dosimetry inaccuracies resulting from in vivo bioassay measurements (Traub and Robinson 1987):

- undetected dose from intake of radioactive material that is removed from the body prior to the radiobioassay

- random and systematic errors in the measurement process

- errors in the mathematical model used to estimate excretion and retention

- uncertainty in the date of the intake and the subsequent fraction of the intake excreted prior to the bioassay

- variation in organ mass among individuals

- variations in the fraction of energy emitted from a source organ and later deposited in a target organ due to relative positions, organ size, shape, etc.

- variations from assumptions in the metabolic model.

Estimation of internal dose is a two-step process. First, the quantity of radioactivity present in an organ or the whole body of an individual is estimated from a physical measurement. Next, the dose is estimated using mathematical models for the metabolism of the radionuclide and energy deposition of emitted radiations. The performance criteria of draft ANSI N13.30 and the measurements discussed in this report only address the random and systematic errors in the first step.

The draft standard specifies numerical values by nuclide for acceptable minimum detectable amount (AMDA), relative bias $\left(B_{r}\right)$, and relative precision $\left(S_{A}, S_{B}\right)$. The standard also includes guidelines to be used by accrediting laboratories to test whether bioassay service laboratories conform to the quantitative performance criteria as well as to standard quality control procedures, such as might be required in a test for laboratory accreditation. The current draft standard has been accepted by ANSI Comittee N13 for trial use, but has not been approved by ANSI as an accepted standard. 
TECHNICAL EVALUATION OF DRAFT ANSI N13.30

Occupational radiation protection is a major area of research at Pacific Northwest Laboratory (PNL) (a) and technical evaluation of draft ANSI N13.30 has been one aspect of PNL's research under a project titled "Technical Evaluation of Draft ANSI Standard N13.30, 'Performance Criteria for Radiobioassay'" (ANSI 1989). The purpose of this project was to evaluate the appropriateness of the draft standard by conducting a bioassay performance intercomparison study. At completion of the first draft standard, the following seven objectives of the project were formulated:

- Establish test procedures for evaluating bioassay laboratories in accordance with the draft standard.

- Set up the necessary laboratory equipment and facilities to conduct preliminary testing of bioassay laboratory performance.

- Conduct two rounds of intercomparison testing.

- Compile results and compare the performance of bioassay laboratories with the draft standard performance criteria.

- Analyze the data to determine sources of error.

- Recommend any necessary revisions to the draft standard.

- Prepare a procedures manual for a laboratory to follow in conducting an ongoing performance-testing program for bioassay laboratory accreditation.

This research project involved three major phases: 1) develop testing procedures and establish laboratory facilities for preparing test samples and in vivo phantoms, 2) conduct a pilot intercomparison study with a small number of voluntarily participating in vitro and in vivo laboratories, and 3 ) conduct a second-round intercomparison study with a larger number of participating laboratories. The development of a set of procedures manuals was included in the third phase.

In support of evaluation of the draft standard, PNL has conducted performance tests of bioassay laboratories at DOE facilities, DOE contractor facilities, and other facilities throughout the United States. The results of

(a) Pacific Northwest Laboratory is operated for the U.S. Department of Energy by Battelle Memorial Institute under Contract DE-ACO6-76RLO 1830. 
these studies were used to verify the appropriateness of the criteria selected by the HPS Committee.

The previous PNL studies evaluated bioassay laboratory performance as follows:

- two rounds of analysis of radjoactivity in an artificial urine matrix (Robinson, Fisher, and Hadley 1984; MacLellan, Fisher, and Traub 1988)

- a single round of testing using artificial fecal samples (MacLellan 1988)

- a pilot test of laboratories that perform direct measurements (in vivo bioassay) of radioactive material in occupationally exposed individuals (Robinson et al. 1986).

The project has also investigated the effect of using discrete versus uniform source distributions in testing phantoms (Scherpelz and MacLellan 1987), and it provided the recommended procedures manuals for the proposed DOE accreditation laboratory (Fenrick and MacLellan 1988a; Fenrick and MacLellan 1988b; MacLellan and Traub 1988).

This report, on the second round of in vivo testing, completes PNL's evaluation phase of the project. It includes a description of the two rounds of in vivo testing, a discussion of the results of those rounds, and recommendations for future revisions of draft ANSI N13.30. The results from this and previous PNL reports and future PNL work will greatly assist in the establishment and design of a bioassay laboratory accreditation program at the DOE Radiological and Environmental Sciences Laboratory at the Idaho National Engineering Laboratory in Idaho Falls, Idaho. 


\section{QUALITY ASSURANCE}

This research project conformed with PNL's internal quality assurance (QA) guidelines and with draft ANSI N13.30. As the testing laboratory, PNL was bound by the same $Q A$ requirements as the participating laboratories.

At PNL, all equipment and laboratory procedures or evaluations were documented in laboratory notebooks and records books. All radionuclide solutions used for spikes were obtained from the National Institute of Standards and Technology (NIST) or a supplier with calibrations traceable to NIST.

Participating laboratories were guided by $Q A$ instructions presented in Section 5 of the draft standard. 


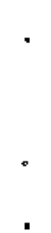

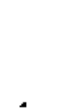

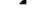




\section{METHODS}

Round One of in vivo testing was conducted by PNL using volunteer bioassay laboratories. Three types of phantoms (i.e., whole body bottle phantom, torso phantom with interchangeable lung sets, and thyroid phantom) were distributed in a round-robin fashion to the participating laboratories. Round Two involved a larger number of laboratories and different test radionuclides, but used only torso and whole body phantoms.

\section{LABORATORY PARTICIPATION}

Invitations to participate in the two-round intercomparison study were initially extended during the 27th Conference on Bioassay, Analytical, and Environmental Chemistry in 1981. Announcements about the opportunity to participate in the study were also published at various times in the HPS News letter. Invitations to participate and details of the Round One testing process were mailed to about 40 bioassay laboratories that had responded to the announcement and to other potential participants. With each invitation was a response form and this information:

- Participation would be entirely voluntary.

- All costs pertaining to the measurement of samples or phantoms would be borne by the participating laboratory.

- A11 laboratory names, categories of participation, and the identification of individual results would be strictly confidential to allow uninhibited participation.

In vivo counting facilities that indicated their desire to participate were then contacted by telephone. Further information and instructions regarding the study were sent to each interested participant.

For Round Two, letters of inquiry were sent to the previous participants and other facilities that had indicated interest in participating. The instructions and information provided were similar to Round One.

Round One Pilot Study

Five in vivo measurement categories with seven test radionuclides were offered during the first round of testing: 
- lung measurements for $241_{\text {Am }}$

- lung measurements for $235 y$

- lung measurements for ${ }^{60} \mathrm{Co}$

- whole body measurements for ${ }^{60} \mathrm{Co},{ }^{137} \mathrm{Cs},{ }^{144} \mathrm{Ce}$

- thyroid measurements for ${ }^{131} 1_{\mathrm{I}}$

Table 1 shows the test radionuclides and activity ranges for in vivo performance testing that were chosen for the first-round intercomparison study. The radionuclides were selected from a list provided in an early version of draft ANSI 13.30. Strontium-90 and/or $40 \mathrm{~K}$ were added to the phantom to provide an intentional background "interference" to more closely represent the actual counting of human subjects. The acceptable test ranges given in Table 1 were changed in later versions of draft ANSI N13.30.

TABLE 1. Round One Test Radionuclides, Organs, and Activity Ranges for In Vivo Performance Testing (from the $1982 \mathrm{draft}$ of ANSI N13.30)

\begin{tabular}{|c|c|c|c|}
\hline Category & Organ & Radionuclide(s) & $\begin{array}{l}\text { Activity Test } \\
\text { Ranges (nCi) } \\
\end{array}$ \\
\hline $\begin{array}{l}\text { Photons with } \\
\text { energy } \leq 60 \mathrm{keV}\end{array}$ & Lung & $241_{A m}(a)$ & $1.0-10.0$ \\
\hline $\begin{array}{l}\text { Photons with } \\
\text { energy } 100-200 \mathrm{keV}\end{array}$ & Lung & $235_{u}(a)$ & $0.75-7.5$ \\
\hline $\begin{array}{l}\text { Photons with } \\
\text { energy }>200 \mathrm{keV}\end{array}$ & Lung & ${ }^{60} \mathrm{Co}(\mathrm{a})$ & $40.0-400$ \\
\hline $\begin{array}{l}\text { Uniformly distributed } \\
\text { fission and products }\end{array}$ & Whole body & $\begin{array}{l}60 \mathrm{Co} \\
137 \mathrm{Cs} \\
144 \mathrm{Ce}^{(\mathrm{b})}\end{array}$ & $\begin{array}{l}200-2000 \\
250-2500 \\
300-3000\end{array}$ \\
\hline $\begin{array}{l}\text { Radionuclides in } \\
\text { the thyroid }\end{array}$ & Thyroid & $131_{I}$ & $40.0-400$ \\
\hline
\end{tabular}


Fifteen facilities participated in one or more of the five categories of lung and whole body counting. These included five national laboratories, one university, one fuel fabrication facility, and eight reactor sites. Each facility was given the option of performing measurements in any or all of the above categories, depending on their need and interest. In general, the DOE-contractor laboratories performed measurements in all categories, whereas facilities regulated by the U.S. Nuclear Regulatory Commission (NRC) were primarily interested in measurenents involving fission and activation products. Round Two Testing

Four different in vivo measurement categories were offered during Round Two testing:

- lung measurements for $238 \mathrm{Pu}$

- lung measurements for natural uranium

- lung, measurements for fission/activation products (i.e., ${ }^{54} \mathrm{Mn}$ and ${ }^{144} \mathrm{Ce}$ )

- whole body measurements for ${ }^{134} \mathrm{Cs}$ and ${ }^{137} \mathrm{Cs}$.

Table 2 shows the test radionuclides and activity ranges for in vivo performance testing that were chosen for the second-round intercomparison study. All phantoms contained ${ }^{40} \mathrm{~K}$ to provide an intentional background "interference" to more closely represent the actual counting of human subjects. The phantoms also contained specific interference radionuclides; the fission product lung phantom contained ${ }^{134} \mathrm{Cs}$ and ${ }^{137} \mathrm{Cs}$ and the whole body phantom contained ${ }^{54} \mathrm{Mn}$ and ${ }^{60} \mathrm{Co}$. In accordance with draft ANSI N13.30, these radionuclides were present for interference but were not used for testing. The acceptable test ranges given in Table 2 are from the latest version of the standard.

Twenty-seven facilities participated in one or more of the four lung and whole body counting categories. These included five national laboratories, one nuclear vendor, two DOE contractors, one non-DOE federal facility, and eleven commercial reactor sites. Each facility was given the option of performing measurements in any or all of the above categories, depending on their need and interest. Again, the DOE laboratories performed measurements 
IABLE 2. Round Two Test Radionuclides, Organs, and Activity Ranges for In Vivo Performance Testing (from August $1987 \mathrm{draft}$ of ANSI N13.30)

\begin{tabular}{|c|c|c|c|c|}
\hline $\begin{array}{l}\text { Category } \\
\text { Number }\end{array}$ & Category & Organ & Radionuclide $^{(a)}$ & $\begin{array}{c}\text { Testing } \\
\text { Activity } \\
\text { Ranges, } \\
\mu \mathrm{C} i\end{array}$ \\
\hline I & $\begin{array}{l}\text { Measurement of } \\
\text { transuranium elements } \\
\text { via } L \text { x-rays }\end{array}$ & Lung & $238 \mathrm{Pu}$ & 0.05 to 5 \\
\hline III & $\begin{array}{l}\text { Measurement } \\
\text { of } 234 \mathrm{Th}\end{array}$ & Lung & Natural uranium & 0.03 to 3 \\
\hline v & $\begin{array}{l}\text { Measurement } \\
\text { of fission and } \\
\text { activation products }\end{array}$ & Lung & $\begin{array}{l}54 \mathrm{Mn} \text { and } \\
144_{\mathrm{Ce}}(\mathrm{b})\end{array}$ & $\begin{array}{l}0.02 \text { to } 2 \\
0.2 \text { to } 20\end{array}$ \\
\hline VI & $\begin{array}{l}\text { Measurement } \\
\text { of fission and } \\
\text { activation products }\end{array}$ & Whole body & $\begin{array}{l}134 \mathrm{Cs} \text {, and } \\
137 \mathrm{Cs}(\mathrm{C})\end{array}$ & $\begin{array}{l}0.02 \text { to } 2 \\
0.02 \text { to } 2\end{array}$ \\
\hline
\end{tabular}

(a) In addition to the specified test radionuclide(s), $40_{\mathrm{K}}$ shall be present with an activity in the range of 0.05 to $0.10 \mu \mathrm{Ci}$ for lung categories, and in the range of 0.08 to $0.16 \mu \mathrm{Ci}$ for the total body

(b) $13{ }^{2} \mathrm{Cs}$ and $137 \mathrm{Cs}$ shall be present as interference nuclides

(c) $54_{\mathrm{Mn}}$ and ${ }_{60}{ }^{\mu \mathrm{Ci}} \mathrm{Co}$ each) shall be present as interference nuclides $(0.02$ to $2 \mu \mathrm{Ci}$ each).

in all categories, whereas NRC-regulated facilities were primarily interested in measurements involving fission and activation products. All participating facilities received an in vivo measurements report form (see sample in Appen$\operatorname{dix} A)$. Table 3 lists the AMDAs for the test radionuclides used in Round Two testing, as determined by the 1987 draft ANSI N13.30.

\section{PREPARATION OF IN VIVO PHANTOMS}

Phantom preparation procedures for Round One of this study were described by Robinson et al. (1986). For Round Two, all lung and BOMAB phantoms were prepared by PNL. The foaming polyurethane used in Round One for lung phantoms was not available in small batches from the original supplier, so a new 
TABLE 3. Acceptable Minimum Detectable Amounts for Nuclides Used in Round Two Testing (from the 1987 draft ANSI N13.30)

\begin{tabular}{|c|c|c|c|c|}
\hline $\begin{array}{l}\text { Category } \\
\text { Number }\end{array}$ & Category Description & Organ & Radionuclide & $\begin{array}{l}\text { AMDA } \\
(\mathrm{nCi})\end{array}$ \\
\hline I & $\begin{array}{l}\text { Measurement of trans- } \\
\text { uranium elements via } \\
L-x \text { rays }\end{array}$ & Lung & $238 \mathrm{Pu}$ & 46 \\
\hline III & Measurement of ${ }^{234} \mathrm{Th}$ & Lung & $U_{\text {nat }}$ & 3 \\
\hline$v$ & $\begin{array}{l}\text { Measurement of fission } \\
\text { and activation products }\end{array}$ & Lung & ${ }^{54} 4_{M n}$ & 20 \\
\hline$v$ & $\begin{array}{l}\text { Measurement of fission } \\
\text { and activation products }\end{array}$ & Lung & ${ }^{144} \mathrm{Ce}$ & 185 \\
\hline VI & $\begin{array}{l}\text { Measurement of fission } \\
\text { and activation products }\end{array}$ & Total body & $137 \mathrm{Cs}$ & 24 \\
\hline VI & $\begin{array}{l}\text { Measurement of fission } \\
\text { and activation products }\end{array}$ & Total body & ${ }^{134} \mathrm{Cs}$ & 21 \\
\hline
\end{tabular}

supplier was used, (a) which allowed pre-mixed batches of the identical lung material to be molded into lungs according to the original Lawrence Livermore National Laboratory (LLNL) lung formulation. All radionuclide solutions were obtained either directly from NIST or from suppliers with calibrations directly traceable to NIST. Propagation of error in radionuclides incorporated into the phantoms is detailed in Appendix B.

Two types of phantoms were prepared. The first type of phantom is an appropriate blank as described in draft ANSI N13.30. This phantom contained only ${ }^{40} \mathrm{~K}$. The second type of phantom, a test phantom, was identical to the blank phantom except for the addition of the test radionuclides. The purpose of the blank phantom was to allow for estimation of the minimum detectable amount (MDA) of the service laboratory. The test phantom was used to estimate the bias and precision of the service laboratory. Lung phantoms with activities less than 10 times the AMDA were also used to evaluate the performance of the service laboratory near the AMDA for the given procedure, and for verification of the MDA calculations. The service laboratory was requested to

(a) The new supplier of foaming polyurethane was Radiological Support Services, Long Beach, California. 
make five replicate analyses of each phantom, removing and repositioning the phantom after each analysis.

Whole Body Phantom Preparation

Draft ANSI N13.30 requires that the whole body phantom used for testing purposes be commercially available and that the activity be uniformly distributed throughout the phantom. A BOMAB (a) whole body bottle phantom, consisting of 10 sturdy polyethylene circular or elliptical right cylinders, was used for this study. Each cylinder was fitted with a screw-cap to accormodate filling. The bottles of the phantom were of various sizes and volumes that approximated the whole body proportions of an adult male of average stature. The dimensions and volumes of the phantom are given in Table 4.

Each of the bottles of the phantom were filled with a solution that contained the appropriate quantity of radionuclides and $40_{K}$ in a gelatin solution. The purpose of the gelatin was to stabilize the radionuclide solution and to reduce leakage if a segment was dropped and broken. The potassium included in the phantor approximated the potassium content of an adult, giving the approximate ${ }^{40} \mathrm{~K}$ body burden of $120 \mathrm{nCi}$.

\section{Preparation of Whole Body Phantom Spike Solutions}

The radionuclide spike solutions were prepared at PNL according to the methods developed in the previous pilot testing study (Robinson et al. 1986). According to the current ANSI $13.30 \mathrm{draft}$, the quantity of radionuclide placed in the whole body phantom for purposes of testing relative precision and relative bias must exceed 10 times the AMDA for the particular radionuclide. A solution containing $0.444 \mathrm{nCi} / \mathrm{g}$ of $54 \mathrm{Mn}, 0.352 \mathrm{nCi} / \mathrm{g}$ of ${ }^{134} \mathrm{Cs}$, $0.440 \mathrm{nCi} / \mathrm{g}$ of ${ }^{137} \mathrm{Cs}$, and $0.252 \mathrm{nCi} / \mathrm{g}$ of ${ }^{60} \mathrm{Co}$ was prepared to form a stock solution. During the preparation of the stock solution, the dilutions of individual radionuclides did not exceed a factor of about $1: 1000$. During dilution of the radionuclides, precautions were taken to ensure that the radionuclide did not adhere to the surface of the container; the radionuclide solution was diluted with nitric acid. Aliquants of the phantom

(a) The BOMAB (bottle-manikin-absorption) whole body bottle phantom is manufactured by Atlantech, Inc., Roswe 11, Georgia, and NE Tech, Inc., Mammouth Junction, New Jersey. 
TABLE 4. Dimensions of Phantom Bottles Representing Human Body Parts

\begin{tabular}{|c|c|c|c|c|c|}
\hline Part & Shape & $\begin{array}{c}\text { Cross } \\
\text { Section }(\mathrm{cm})\end{array}$ & Length $(\mathrm{cm})$ & $\begin{array}{c}\text { Volume } \\
\text { (mL) }\end{array}$ & $\begin{array}{l}\text { Percent } \\
\text { of Total }\end{array}$ \\
\hline Head & Ellipse & $19 \times 17$ & 20 & 3,244 & 5.8 \\
\hline Neck & Circle & 13 & 10 & 900 & 1.6 \\
\hline Thorax & Ellipse & $30 \times 20$ & 40 & 16,370 & 29.1 \\
\hline Abdomen & Ellipse & $36 \times 20$ & 20 & 9,118 & 16.2 \\
\hline Arms (2) & Circle & 10 & 60 & 7,305 & 13.0 \\
\hline Thighs (2) & Circle & 15 & 40 & 11,970 & 21.3 \\
\hline Legs (2) & Circle & 12 & 40 & 7,362 & 13.0 \\
\hline Total & & & & 56,269 & 100.0 \\
\hline
\end{tabular}

stock, in proportion to the "percent of total" column in Table 4, were preweighed into plastic containers; one for each phantom segment.

\section{Preparation of Whole Body Phantom Body Parts}

BOMAB phantom body parts were prepared at PNL according to the following procedure. A warm gelatin mixture was prepared by dissolving $300 \mathrm{~g}$ of gelatin in $2.5 \mathrm{~L}$ of water. The gelatin solution was poured into each phantom section until the section was about half full. The pre-weighed radionuclide solution was neutralized with an appropriate volume of $\mathrm{KOH}$ solution and poured into the phantom segment. The radionuclide bottle was rinsed several times and the rinse solution was poured into the body segment. Benzalkonium chloride ( $16 \mathrm{~mL} / \mathrm{L}$ of a $17 \%$ solution) was added to the phantom segment to inhibit the growth of microorganisms, and sodium metabisulfate $(5 \mathrm{~g} / \mathrm{L})$ was added to retard the oxidation of the gelatin. The phantom segments were tilted back and forth until the solution was completely mixed. Food coloring was added to the segment prior to the mixing process, and the distribution of the food coloring was used to gauge the degree of mixing achieved.

Draft ANSI $N 13.30$ states that the phantom shall contain $40 \mathrm{~K}$ in an amount equivalent to that contained in a person of average stature (0.08-0.16 $\mu \mathrm{Ci})$. Enriched $40_{K}$ was not available, so the requisite activity was obtained using $270 \mathrm{~g}$ of $\mathrm{KCl}$ (an isotopic abundance of $0.0118 \%$ for ${ }^{40} \mathrm{~K}$ in potassium was assumed). The $120 \mathrm{nCi}$ of ${ }^{40} \mathrm{~K}$ was distributed among the phantom segments in proportion to the "percent of total" column of Table 4. 
The phantom segments were filled by adding gelatin solution in smat1 increments, and the contents were mixed after each addition. When the segment was filled and well mixed, it was placed in a refrigerator to cool and solidify. The total activity of each radionuclide in the whole body phantom is shown in Table 5. Only the cesium isotopes were intended to be quantified by the participating laboratories.

A "blank" phantom was also prepared for use in estimating the MDA. This phantom was identical to the phantom that contained the test radionuclides, except that no spike solution or interference radionuclides were added. The $40 \mathrm{~K}$ content was the same as that of the test phantom. Different colors of food coloring were used to distinguish between the blank and test phantoms, but they were not identified as to which was which.

\section{Lung Phantom Preparation}

The Iung phantom specified by draft ANSI $N 13.30$ is a realistic simulation of the torso, skeleton, and lungs of a man of average stature. According to the 1987 draft ANSI N13.30, the phantom should have a chest wall over the lungs that simulates muscle tissue with a thickness in the range of 1.4 to $1.7 \mathrm{~cm}$. The simulated tissues of the phantom should have transmission and scatter characteristics for low-energy photons that closely approximate those for normal tissue. The torso phantom should have interchangeable pairs of simulated lungs in which the test radionuclide is uniformly distributed.

The torso phantom used during intercomparison testing was a "Realistic Phantom" developed at LLNL and marketed commercially by the Humanoid Systems,

TABLE 5. Total Activity of Test and Interference Radionuclides in the BOMAB Whole Body Bottle Phantom

\begin{tabular}{|c|c|}
\hline Radionuc Jide & Total Activity (nCi) \\
\hline${ }^{134}$ Cs & $299 \pm 8$ \\
\hline${ }^{137} \mathrm{Cs}$ & $374 \div 5$ \\
\hline${ }^{54} M_{n}$ & $377+10-8$ \\
\hline${ }^{60} \mathrm{Co}$ & $214 \pm 5$ \\
\hline
\end{tabular}


Inc. (now Radiological Support Services, in Long Beach, California). (a) The phantom was constructed of tissue-equivalent plastic materials and plastic bone. The phantom contains interchangeable pairs of simulated lungs with a density of $0.3 \mathrm{~g} / \mathrm{cm}^{3}$, which were produced at PNL from kits supplied by the manufacturer.

For the final round of the intercomparison study, kits were obtained from the phantom manufacturer that allowed custom fabrication of lung sets. The kit material consisted of two parts: a black urethane plastic and a catalyst. The radionuclide solution was mixed with the plastic component prior to polymerization. Addition of the catalyst causes polymerization and foaming of the urethane material. After the lungs were formed they were sealed with a polyurethane coating. The final product was a lung-shaped object that contained a uniform distribution of radioactivity, the total quantity of which was well characterized.

\section{Preparation of the Lung Spike Solutions}

Draft ANSI N13.30 states that for testing the bias and precision of the service laboratory, the radionuclides shall be in the lungs in a quantity that is at least 10 times the AMDA for the particular radionuclide and with in the range of activity listed in Table 3 of the current draft standard. The testing quantity can be any quantity chosen by the performance-testing laboratory within the range of 10 to 100 times the AMDA. In accordance with the performance testing procedures (MacLellan and Traub 1988), this quantity is called the TQ.

A solution containing the TQ of each radionuclide was prepared to form a phantom stock solution. During the preparation of the phantom stock solution the dilutions of individual radionuclides did not exceed a factor of about $1: 1000$. Nitric acid was added to the solution to ensure that the radionuclide did not adhere to the surface of the container.

(a) Reference to a company or product name does not imply approval, recommendation, or endorsement by Pacific Northwest Laboratory or the U.S. Department of Energy to the exclusion of other companies or products that may be suitable. 
The TQ was partitioned between the right and the left lung in proportion to the relative mass of each lung. These quantities will be referred to as $T Q-R$ and TQ-L, respectively, and are determined as follows:

$$
\begin{aligned}
& \mathrm{TQ}-\mathrm{R}=0.56 \mathrm{TQ} \\
& \mathrm{TQ}-\mathrm{L}=0.44 \mathrm{TQ} .
\end{aligned}
$$

The test solutions were prepared using gravimetric means rather than volumetric means, because Standard Reference Materials are calibrated for gravimetric dispensing and gravimetric methods avoid the necessity of temperature corrections for the volumes. The balances used were calibrated with weights traceable to NIST.

In addition to the test phantoms that contained 10 to 100 times the AMDA quantity, one set of blank lungs with only the added $\mathrm{KCl}$ and one set of lungs with added activity near the AMDA were also prepared for each category.

${ }^{238} \mathrm{Pu}$ Solutions. Standard Reference Materials solutions of ${ }^{238} \mathrm{Pu}$ were ordered from NIST. The solutions were packaged by NIST so that the desired quantity for each lung was in a separate vial. The vials were opened, weighed, emptied into the lung material, and then reweighed. The material dispensed into the lung material was assumed to equal the loss in mass of the vial.

Activation/Fission Product Solutions. The lungs for the activation/ fission product phantoms contained four radionuclides; two test radionuclides $\left({ }^{54} \mathrm{Mn}\right.$ and $\left.{ }^{144} \mathrm{Ce}\right)$ and two interference radionuclides $\left({ }^{134} \mathrm{Cs}\right.$ and $\left.{ }^{137} \mathrm{Cs}\right)$. Each radionuclide was diluted so that $T Q-L$ and $T Q-R$ were in a volume from $0.12 \mathrm{~mL}$ to no more than $1.2 \mathrm{~mL}$. The solutions were prepared so that the TQ was in the smallest possible volume. The ${ }^{54} \mathrm{Mn}$ and ${ }^{144} \mathrm{Ce}$ solutions were obtained from a commercial vendor with demonstrated traceability to NIST. The stock solutions contained $2.629 \mu \mathrm{Ci} / \mathrm{g}$ of ${ }^{54} \mathrm{Mn}$ and $4.373 \mu \mathrm{Ci} / \mathrm{g}$ of ${ }^{144} \mathrm{Ce}$.

Natural Uranium Solutions. Standard Reference Materials of natural uranium metal were obtained from the New Brunswick Laboratory, in Argonne, Illinois. To prepare the metal as a solution the metal chip was dipped in $1: 1 \mathrm{HNO}_{3}$ for about 10 minutes to remove the surface oxide on the metal, rinsed in distilled water, then etched in 1:3 HCl for 5 minutes. The metal was then 
rinsed thoroughly in distilled water, patted dry with a lint-free wiper, and placed in a vacuum desiccator for one-half hour to accelerate removal of surface moisture and retard re-oxidation of the metal. After about 30 minutes, the chip was periodically reweighed until a constant weight was achieved. Only clean stainless steel forceps were used to handle the metal and the weighing was done on a calibrated balance.

After a constant weight was achieved for the uranium metal it was placed in a tared Pyrex ${ }^{n}$ flask and enough $1: 1 \mathrm{HNO}_{3} / 3 \mathrm{~N} \mathrm{HCl}$ was added to dissolve the metal. After the metal was dissolved, the flask was reweighed. The formula for the concentration of the uranium solution (CUS) is:

$$
\text { CUS }=\frac{\text { mass of uranium chip }}{F^{2}-F 1}
$$

where $F 2$ is the mass of the flask including the uranium and dissolving solution and $\mathrm{Fl}$ is the flask tare weight. The solution activity was determined to be $0.0607 \mathrm{~g}-U(n a t) / g$. With an assay error of $\$ 0.017 \%$. The formula for the quantity of the solution placed into each lung was:

$$
\begin{aligned}
& \text { Mass of solution for left lung }=(T Q-L) / \text { CUS } \\
& \text { Mass of solution for right lung }=(T Q-R) / C U S \text {. }
\end{aligned}
$$

\section{Preparation of Lung Phantoms}

Lung phantoms are prepared using lung molds and plastic lung material. The lung molds were prepared by first cleaning them with acetone and then lubricating them with a silicone grease (Dow Corning \#4 silicone grease). The lung material used was obtained as a two-component kit. One component is a black plastic, the other is a clear catalyst (isocyanate) that promotes the reaction of the foam. Only a very small volume of the radionuclide solution can be incorporated into the plastic component. (The manufacturer recommends that the volume be less than $0.5 \mathrm{~mL}$, although PNL has incorporated up to $5 \mathrm{~mL}$ of radionuclide solution at PNL without significant loss of viscoelasticity of the plastic.)

Pyrex is a registered trademark of Dow-Corning Glass Works, Corning, New York. 
The first step in the preparation of the lung phantoms, was to record the mass of the black plastic material in the mixing container. Then, the radionuclide solution was added to the plastic component. Although human lung actually contain very little potassium, draft ANSI N13.30 specifies that KCI also be added to the lung material. The lungs themselves had a total of $3.8 \mathrm{~g}$ $\mathrm{KCl}$ added to them, with the remaining $152 \mathrm{~g}$ (which equates to approximately $70 \mathrm{nCi}$ of $40 \mathrm{~K}$ ) added to the phantom cavity. The phanton cavity contained $42 \mathrm{~g}$ located in the heart cavity and $110 \mathrm{~g}$ located in plugs throughout the abdominal block. This distribution was chosen as an approximation of the $K$ distribution in organs as noted in ICRP 23 . The plastic component was then thoroughly mixed with a paint stirrer attached to a hand-held power drill.

The catalyst component was mixed well, then drawn into two $50-\mathrm{mL}$ syringes with luer fittings. The luer fittings have a smaller orifice and produce more force for the catalyst injection than catheter fittings. After the syringes had been filled with catalyst material, their mass was recorded.

Next, one individual mixed the black plastic component using the handheld drill with its attached paint stirrer. The second person added the catalyst, emptying the two syringes simultaneously. The streams from the syringes were moved back and forth to aid in the mixing of the catalyst.

After the catalyst was injected into the black plastic, the mass of the catalyst syringes was recorded. The plastic and catalyst were mixed for about 10 seconds and then the mixture was poured into the bottom half of the lung mold. The remaining mixture was scraped from the mixing container into the bottom half of the lung mold with a tongue depressor. When all of the lung material was transferred, the top of the lung mold was clamped into place. The vent hole at the top of the lung mold was closed with a stopper when plastic material began to exude from the hole.

The lung phantom was then allowed to set for at least 1 hour before removing it from the mold. Once removed from the mold, the mold was cleaned with acetone. After triming off all of the material that leaked out between the two halves of the lung mold, the lung was weighed to determine its mass. Finally, the lung was painted with a polyurethane coating material (as a sealant) and identifying marks were applied using white model paint. 


\section{Test Lung Radionuclide Activity}

The radionuclide concentration (C) in the lung material was calculated using the following equation:

$$
C=\frac{A_{r}}{\left(M_{B}+M_{C}+M_{R}+M_{X}\right)}
$$

where $M_{B}=$ Mass of black plastic (the mass of the material placed into the mixing container)

$A_{r}=$ Activity of added test radionuclide solution in nanocuries

$M_{C}=$ Mass of catalyst (the mass of the full catalyst syringes minus the mass of the emptied catalyst syringes)

$M_{R}=$ Mass of the radionuclide solution

$M_{x}=$ Mass of $\mathrm{xCl}$.

The activity in the lung material (AL) was determined using the following equation:

$$
A_{L}=M_{L} \times C
$$

where $M_{L}$ equals the mass of the lungs after trimming off the excess material and before applying the sealant. The activities of each test radionuclide are shown in Table 6 .

\begin{tabular}{|c|c|c|c|c|c|}
\hline $\begin{array}{l}\text { Category } \\
\text { Number }\end{array}$ & Category & $\begin{array}{l}\text { Radio- } \\
\text { nuclide }\end{array}$ & $\begin{array}{c}\text { Calibration } \\
\text { Date }\end{array}$ & $\frac{\text { Phantom Ac }}{\text { Test Lungs }}$ & $\frac{\text { ivity (nCi) }}{\text { MDA Lungs }}$ \\
\hline I & $\begin{array}{l}\text { Measurement of } \\
\text { transuranics } \\
\text { via } L \text { x-rays }\end{array}$ & $238 \mathrm{Pu}$ & JuTy 21, 1986 & $374 \pm 8$ & $32 \pm 1$ \\
\hline III & $\begin{array}{l}\text { Measurement of } \\
{ }^{234} \mathrm{Th}\end{array}$ & $U_{\text {nat }}$ & June 30,1986 & $33 \pm 1$ & $3.5 \pm 0.1$ \\
\hline \multirow[t]{2}{*}{$v$} & \multirow{2}{*}{$\begin{array}{l}\text { Measurements } \\
\text { of fission } \\
\text { and activation } \\
\text { products }\end{array}$} & ${ }^{54} M n$ & June 27,1986 & $\begin{array}{r}663+18 \\
-14\end{array}$ & $65 \pm 1$ \\
\hline & & ${ }^{144} \mathrm{Ce}$ & June 27,1986 & $1926 \pm 60$ & $223 \pm 7$ \\
\hline
\end{tabular}

TABLE 6. Round Two Performance Test Lung Activities 


\section{PHANTOM IDENTIFICATION AND SHIPMENT TO PARTICIPATING LABORATORIES}

The primary marking on the Iung phantoms was of the type "nnnnn-xx," where nnnnn was the laboratory notebook number and $x x$ was the page number of the notebook that contained the data recorded during the manufacture of the lung material. The lungs were coded with a nuclide identifier and a random number designation (1 through 3) for the spike level (i.e., test level, MDA level, or blank).

The test radionuclide activity levels qualified under the "limited quantity" designation of 49 CFR 173. The sample containers were packaged and labeled in compliance with federal regulations for packaging and shipping and they were shipped by surface carrier. The shipping of "limited quantity" activity levels does not require any external radiation labeling on the box. 


\section{DATA EVALUATION}

Following the receipt of analysis data for all samples sent to the service laboratories, the test statistics for the performance report were calculated in accordance with draft ANSI N13.30 and the recomended procedures for the performance testing (MacLellan and Traub 1988). The performance criteria included the relative bias $\left(B_{r}\right)$, relative precision $\left(S_{A}\right.$ and $\left.S_{B}\right)$, and the MDA for each test nuclide analyzed by the service laboratory. Additional confidence intervals were calculated for these criteria according to methods described in the section "Confidence Intervals for the Performance Criteria."

\section{DRAFT ANSI $N 13.30$ PERFORMANCE CRITERIA}

The performance criteria as they are currently specified in the latest (August 1987) draft of ANSI N13.30 were used in the analyses of the in vivo counting data. Additionally, methods of introducing confidence intervals based on Poisson statistics were developed and introduced to determine the outer bounds of the various performance criteria statistics. A discussion of the current criteria and the basis for them is provided here.

Relative Bias

The relative bias $\left(B_{r}\right)$ was calculated from the analysis data reported by the service laboratory using the following equations:

$$
\begin{aligned}
B_{r i} & =\frac{A_{i}-A_{a i}}{A_{a i}} \\
B_{r} & =\sum_{i=1}^{N} B_{r i} / N
\end{aligned}
$$

where $B_{r j}=$ the relative bias of the $i$ th sample in the activity category $B_{r}=$ the mean relative bias of all replicates in the activity category

$A_{i}=$ the reported result in the $i$ th activity category

$A_{a j}=$ the true activity for the ith activity category

$$
N=\text { the number of samples or replicates per activity category. }
$$




\section{Relative Precision}

The relative precision estimators $\left(S_{A}\right.$ and $S_{B}$ ) were also calculated from the analysis data reported by the service laboratory using the following equations:

$$
\begin{aligned}
& S_{A}=\left[\sum_{i=1}^{N}\left[\left(A_{i} / \bar{A}\right)-1\right]^{2} /(N-1)\right]^{\frac{1}{k}} \\
& S_{B}=\left[\sum_{i=1}^{N}\left(B_{r i}-B_{r}\right)^{2} /(N-1)\right]^{\frac{1}{2}}
\end{aligned}
$$

where $\bar{A}$ is the mean reported result for all $N$ samples or replicates in the $i^{\text {th }}$ activity category, and the rest of the terms are the same as those defined above for the Equations ( 8 ) and (9). The above equations for relative precision $\left(S_{A}\right.$ and $\left.S_{B}\right)$ are analogous to equations used in the August $1987 \mathrm{draft}$ ANSI 113.30. The rationale for using two different relative precision equations is provided in Appendix B of the August 1987 draft standard.

Minimum Detectable Amount

Estimation of the MDA requires the evaluation of the variability observed in the measurement of the appropriate blanks. The specific form of the MDA equation will depend on the assumptions made about the count distribution. If the performance test identifies a relative bias for the reported analysis data, the calculated MDA should be multiplied by $1 /\left(1+B_{r}\right)$ to obtain the bias-corrected MDA, for purposes of comparison with the AMDA.

When each sample measurement is paired with an appropriate blank, the non-Poisson errors may be considered to cancel out and a Poisson distribution may be assumed. The measurement procedures tested in this performance test may be considered to be paired observations because the baseline of the gamma spectrum is subtracted from the peak to obtain the net counts. The MDA was therefore calculated using the following equation, which is equivalent to the equation in Section 3.4.1.2 of draft ANSI N13.30. 


$$
M D A=\frac{\left[3.29 s_{0}+2 \Delta_{B} B+3\right]}{K T\left(1+4_{K}\right)}
$$

where $K=$ the calibration factor supplied by the service laboratory for the measurement process in counts per minute per nanocurie

$\Delta_{K}=$ the estimated fractional systematic error in the calibration factor $k$. The upper $95 \%$ bound of the perfornance test estimate of $\mathrm{Br}$ should be used for this factor (Brodsky 1986)

$B=$ the baseline count for the spectrum in the region of interest, including any interference nuclide counts

$\Delta_{B}=$ the estimated fractional systematic error in determining the baseline count $B$ (assumed to have an upper bound of $\pm 5 \%$ when no higher energy interference nuclides are present and $\pm 1 \%$ when higher energy nuclides are present)

$s_{0}=s_{b}(h)=(\bar{x})^{\frac{1}{2}}(h)$, the standard deviation of the net blank count $T=$ the sample count time.

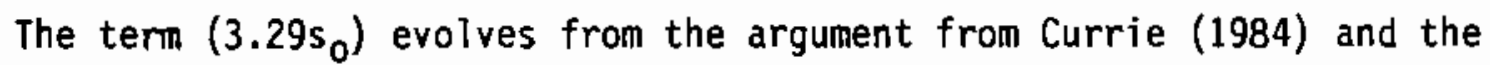
equation deviation is explained by MacLellan (1989). When the standard deviation of the sample measurement is known and constant up to the MDA value, the a priori minimum detectable count (MDC) is just twice the minimum count that will be considered significantly greater than a blank count with $95 \%$ probability. Assuming a normal distribution for the blank data, the MDC is $2(1.645) \mathrm{s}_{0}$ or $3.29 \mathrm{~s}_{0}$ and the MDA would be determined by dividing the result by the appropriate calibration factors. For most measurement systems, the baseline standard deviation is not constant and additional terms are required in the MDA equation numerator. The " $2 \Delta_{B} B$ " term estimates the upper bound for systematic (non-random) errors in the baseline estimate and the " 3 " term accounts for the Poisson-related increase in the standard deviation at the MDA value.

The value of $s_{0}$ may be calculated from the product of the background standard deviation $\left(s_{b}\right)$ multiplied by a factor $(h)$, where $(h)$ equals the square root of $(1+1 / b)$ and $(b)$ is the ratio of the background to sample counting times. The MDA equations then reduce to

$$
M D A=\left(3.29(h) s_{b}+0.10 B+3\right) / K T\left(1+\Delta_{K}\right)
$$


when no interference nuclides are present and the use of a "well-known blank" is used to compare the background and net count spectra, and

$$
M D A=\left(3.29(h) s_{b}+0.02 B+3\right) / K T\left(1+\Delta_{K}\right)
$$

when interference nuclides are present. For paired observations (each sample compared with a single not "well-known blank"), the respective equations reduce further to

$$
M D A=\left(4.65 s_{b}+0.10 B+3\right) / K T\left(1+\Delta_{K}\right)
$$

and

$$
M D A=\left(4.65 s_{b}+0.02 B+3\right) / K T\left(1+\Delta_{K}\right)
$$

The calibration factor, $K$, is equal to the product of the detector counting efficiency, sample volume, and the physical conversion factor for nuclear transformations in the region of interest per unit activity (i.e., decays per minute per nanocurie). This value should be supplied by the service laboratory.

\section{CONFIDENCE INTERVALS FOR THE PERFORMANCE CRITERIA}

Because the performance criteria results were based on a small sample size, it is important to calculate their confidence intervals. The bias is assumed to be normally distributed so that its estimated value follows the $t$-distribution. The confidence interval will therefore be

$$
B_{r} \cdot t\left(S_{B} / \sqrt{ } n\right)
$$

where $n$ is the performance test sample size, $S_{B}$ is the relative precision estimator, and $t$ is listed in Table 7 for the $90 \%$ confidence level. 
TABLE 7. Student's $t$ Statistic at $90 \%$

Confidence Level ( $n \leq 30)$

$\begin{array}{cc}\begin{array}{c}\text { Sample } \\ \text { Size }(n)\end{array} & t \\ 1 & - \\ 2 & 6.314 \\ 3 & 2.920 \\ 4 & 2.353 \\ 5 & 2.132 \\ 6 & 2.015 \\ 7 & 1.943 \\ 8 & 1.895 \\ 9 & 1.860 \\ 10 & 1.833 \\ 15 & 1.751 \\ 20 & 1.729\end{array}$

Since the performance criteria estimates may be based on as few as five replicates, it is important to calculate their confidence intervals. The random variable $(n-1) s^{2} / \sigma^{2}$ follows the chi-square distribution with $n-1$ degrees of freedom (Remington and Schork 1970). To obtain the 5\% lower bound and $95 \%$ upper bound for any standard deviation related term, the $\left(s_{b}\right)$ term should be divided by the value from the third and fifth columns of Table 8 , respectively. These boundary values should then be used in the appropriate MDA equation to obtain the $90 \%$ confidence interval.

The null hypothes is (that the true MDA is less than or equal to the acceptable MDA) should be accepted if the lower $5 \%$ bound for the interval is less than or equal to the acceptable MDA of draft ANSI N13.3D. If the null hypothes is is accepted, the service laboratory should not be failed in the MDA criterion. The acceptable values for bias and precision were established with testing variability in mind and therefore have a built-in confidence interval. 
TABLE 8. Factors for MDA Confidence Interval Estimation

\begin{tabular}{|c|c|c|c|c|}
\hline $\begin{array}{c}\text { Replicates, } \\
n\end{array}$ & $\begin{array}{l}x^{2} \\
0.95 \\
\end{array}$ & {$\left[x^{2} /(n-1)\right]$} & $\begin{array}{l}x^{2} \\
0.05 \\
\end{array}$ & {$\left[x^{2} /(n-1)\right]$} \\
\hline 2 & 3.841 & 1.96 & 0.0393 & 0.063 \\
\hline 3 & 5.991 & 1.73 & 0.103 & 0.227 \\
\hline 4 & 7.815 & 1.61 & 0.352 & 0.343 \\
\hline 5 & 9.488 & 1.54 & 0.711 & 0.422 \\
\hline 6 & 11.070 & 1.49 & 1.145 & 0.479 \\
\hline 7 & 12.592 & 1.45 & 1.635 & 0.522 \\
\hline 8 & 14.067 & 1.42 & 2.167 & 0.556 \\
\hline 9 & 15.507 & 1.39 & 2.733 & 0.584 \\
\hline 10 & 16.919 & 1.37 & 3.325 & 0.608 \\
\hline
\end{tabular}

Source: Remington and Schork (1970).

Confidence Interval for the Estimated Minimum Detectable Amount

Since the estimate of the sample population was assumed to be Poisson distributed, both the mean and variance of the net count were assumed to follow the Poisson distribution, which approximates the nomal distribution for mean values greater than 20 . The $5 \%$ lower bound for the $s_{b}$ term was calculated using the following equation:

$$
s_{b .05}=\sqrt{ }(B-1.645 \sqrt{B})
$$

The lower 5\% bound for the confidence interval of the true MDA value was obtained by substituting $s_{b} .05$ for $s_{b}$ in Equation (13).

Service Laboratory Estimated Minimum Detectable Amount

Each service laboratory was asked to furnish their estimate of the MDA of each radiobioassay procedure it completed. This estimate was compared with the testing laboratory (PNL) results to identify laboratories that may be underestimating the precision of their analyses. 


\section{LABORATORY PERFORMANCE SUMMARY}

The laboratory performance criteria results for both Round One and Round Two testing are sumnarized in Table 9. They are included together in order to more easily contrast the results of each testing round. It should be remembered that the formulae that were used for MDA are not the same in Round Two as those used in Round One. The $S_{A}$ criterion was not added to the standard until after Round One testing was complete. The comparison of the two differently formulated results is only done to judge how changes have affected the performance of the service laboratories.

TABLE 9. Surmary of In Vivo Performance Test Results - Rounds One and Two Round One

\begin{tabular}{|c|c|c|c|c|c|c|}
\hline \multirow[b]{2}{*}{ Category } & \multirow[b]{2}{*}{$\begin{array}{l}\text { Radio- } \\
\text { nuclide }\end{array}$} & \multirow[b]{2}{*}{$\begin{array}{c}\text { Number of } \\
\text { Respondents }\end{array}$} & Number of & Respondent & ts Fajlina & \multirow{2}{*}{$\begin{array}{l}\text { Criterion } \\
\text { Not } \\
\text { Reported (a) }\end{array}$} \\
\hline & & & Bias & $\frac{\text { Precision }}{S_{8}}$ & MDA & \\
\hline $\begin{array}{l}\text { Lung } \\
\text { Lung } \\
\text { Lung } \\
\text { Whole body } \\
\text { Whole body } \\
\text { Subtotal }\end{array}$ & $\begin{array}{l}241_{\mathrm{Am}} \\
235_{\mathrm{U}} \\
60 \mathrm{Co} \\
60 \mathrm{Co} \\
137 \mathrm{Cs}\end{array}$ & $\begin{array}{r}4 \\
5 \\
13 \\
13 \\
13 \\
48\end{array}$ & $\begin{array}{l}0 \\
1(20 \%) \\
8(62 \%) \\
5(38 \%) \\
2(15 \%) \\
16(33 \%)\end{array}$ & $\begin{array}{l}0 \\
0 \\
0 \\
1(8 \%) \\
0 \\
1(2 \%)\end{array}$ & $\begin{array}{l}2(50 \%) \\
2(40 \%) \\
2(15 \%) \\
5(38 \%) \\
5(38 \%) \\
16(33 \%)\end{array}$ & $\begin{array}{l}1(25 \%) \\
2(40 \%) \\
3(23 \%) \\
3(23 \%) \\
2(15 \%) \\
11(23 \%)\end{array}$ \\
\hline $\begin{array}{c}\text { Whole body } \\
\text { Total }\end{array}$ & ${ }^{144} \mathrm{Ce}$ & $\frac{13}{60}$ & $\frac{7(58 \%)}{23(38 \%)}$ & $\frac{5(42 \%)}{6(10 \%)}$ & $\frac{4(33 \%)}{20(33 \%)}$ & $\frac{3(25 \%)}{14(23 \%)}$ \\
\hline
\end{tabular}

Round Two

Radio- Number of $\frac{\text { Number of Respondents Failing Criterion }}{\text { Precision }}$ Category nuclide Respondents

\section{Lung}

Lung

Lung

Lung

Whole body

Whole body Total $238 \mathrm{Pu}$ $238_{\mathrm{U}}$ $54 \mathrm{Mn}$ $144 \mathrm{Ce}$ $137 \mathrm{Cs}$ ${ }^{134} \mathrm{Cs}$

(a) Facilities failing to provide replicate background counts. 
Performance test results are arranged by radionuclide category and sumarized in Tables 10 through 15. Companion Figures 1 through 18 are graphs of the results of testing in each radionuclide category. These scatter diagrams include the limits of the performance criteria as the solid vertical line(s), and any results that lie outside of the limits are considered to have failed the criteria. Horizontal lines are included at the true activity levels for AMDA and 10 times the AMDA to reference laboratory response to the suggested testing level for 10 times the AMDA. The graphs do not show the confidence intervals for the performance criteria estimates. There were only two instances where applying $\mathrm{MOA}_{0.05}$ instead of MDA resulted in additional laboratories passing the MDA criterion. The performance criteria results with respective confidence intervals are listed for each nuclide and laboratory code in Appendix C.

The performance of the three laboratories that reported results for $238 \mathrm{pu}$ is detailed in Table 10 and diagrammed in Figures 1 through 3. Two of the three passed the relative bias criterion, all three passed the relative precision criteria $\left(S_{A}\right)$ and $\left(S_{B}\right)$, and all three passed the MDA criterion. Two of the three facilities had noticeably low bias (negative), which prompted an investigation of the chest wall thickness of the phantom used in the study. It should be noted that the TQ of the AMOA lung set for $238 \mathrm{Pu}$ was below the specified AMDA.

While the Humanoid test phantom was at the PNL whole body counter, PNL personnel compared the transmission properties of $238 \mathrm{Pu} x$-rays through the phantom with those transmission properties through an original LLNL torso phantom. Based on the ratio of counts between the two phantoms and assuming the specified chest wall thickness of the LLNL phantom is correct, the Humanoid test phantom chest wall thickness was calculated to be closer to $1.6 \mathrm{~cm}$ rather than the $1.42 \mathrm{~cm}$ given in the technical specification from the manufacturer. The physical thickness of the chest wall was subsequently measured with calipers and by computerized tomography. The estimates showed some differences in physical thickness from the manufacturer's specification but do not provide information on the density of the phantom material. Therefore, we can only presume at this point that the physical thickness specified by the manufacturer for the Humanoid phantom chest wall may be incorrect, and 
TABLE 10. 238 Pu Lung In Vivo Intercomparison Testing Results (AMDA $=46 \mathrm{nCi}$ )

\begin{tabular}{|c|c|c|c|c|c|c|c|c|c|}
\hline $\begin{array}{l}\text { Laboratory } \\
\text { Code }\end{array}$ & $\frac{(n C}{\text { Activity }}$ & & $\begin{array}{c}\text { Relative } \\
\text { Bias }\end{array}$ & Prec & ion & & Activity & System & \\
\hline A & $\begin{array}{r}31.94 \\
367.66\end{array}$ & $\begin{array}{r}23.0 \\
245.3\end{array}$ & $\begin{array}{l}-0.28 \\
-0.33\end{array}$ & $\begin{array}{l}0.08 \\
0.02\end{array}$ & $\begin{array}{l}0.06 \\
0.01\end{array}$ & 8.2 & $\begin{array}{l}\text { No } \\
\text { No }\end{array}$ & $\begin{array}{l}\text { Phoswich/ } \\
\text { Vault }\end{array}$ & $\begin{array}{l}\text { No } \\
\text { No }\end{array}$ \\
\hline $\begin{array}{l}k \\
k\end{array}$ & $\begin{array}{r}32.38 \\
372.71\end{array}$ & $\begin{array}{r}20.5 \\
289.1\end{array}$ & $\begin{array}{l}-0.37 \\
-0.22\end{array}$ & $\begin{array}{l}0.16 \\
0.04\end{array}$ & $\begin{array}{l}0.10 \\
0.03\end{array}$ & 24 & $\begin{array}{l}\text { No } \\
\text { No }\end{array}$ & $\begin{array}{l}\text { Multi.HPGe } \\
\text { Vault }\end{array}$ & $\begin{array}{l}\text { No } \\
\text { Yes }\end{array}$ \\
\hline N & $\begin{array}{r}31.82 \\
366.31\end{array}$ & $\begin{array}{r}29.0 \\
376.0\end{array}$ & $\begin{array}{r}-0.09 \\
0.03\end{array}$ & $\begin{array}{l}0.28 \\
0.05\end{array}$ & $\begin{array}{l}0.26 \\
0.05\end{array}$ & 26 & $\begin{array}{l}\text { No } \\
\text { No }\end{array}$ & $\begin{array}{l}\text { Mult..HPGe } \\
\text { Vault }\end{array}$ & $\begin{array}{l}\text { Yes } \\
\text { Yes }\end{array}$ \\
\hline
\end{tabular}

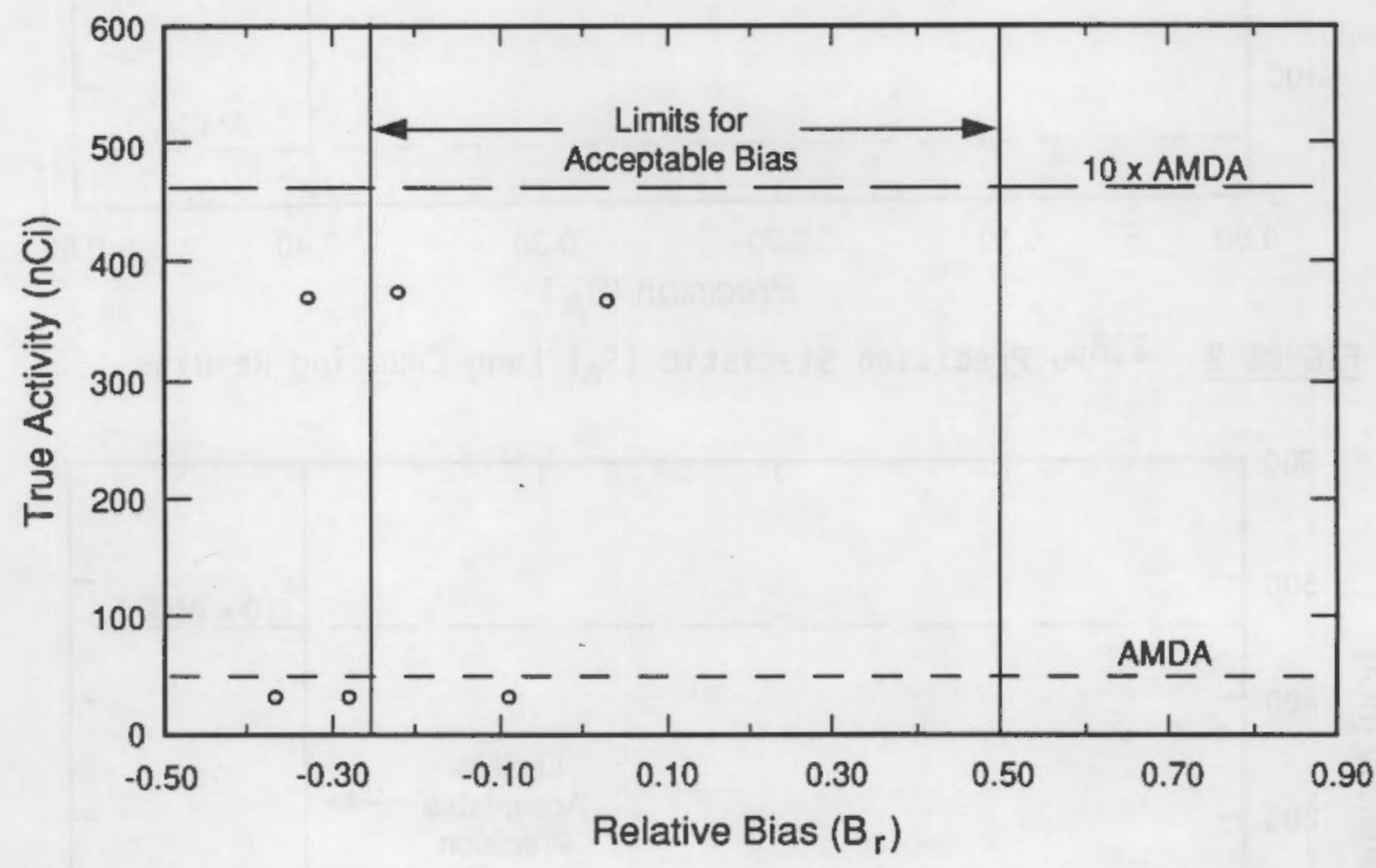

FIGURE 1. 238 Pu Bias Statistic $\left(\mathrm{B}_{r}\right)$ Lung Counting Results 


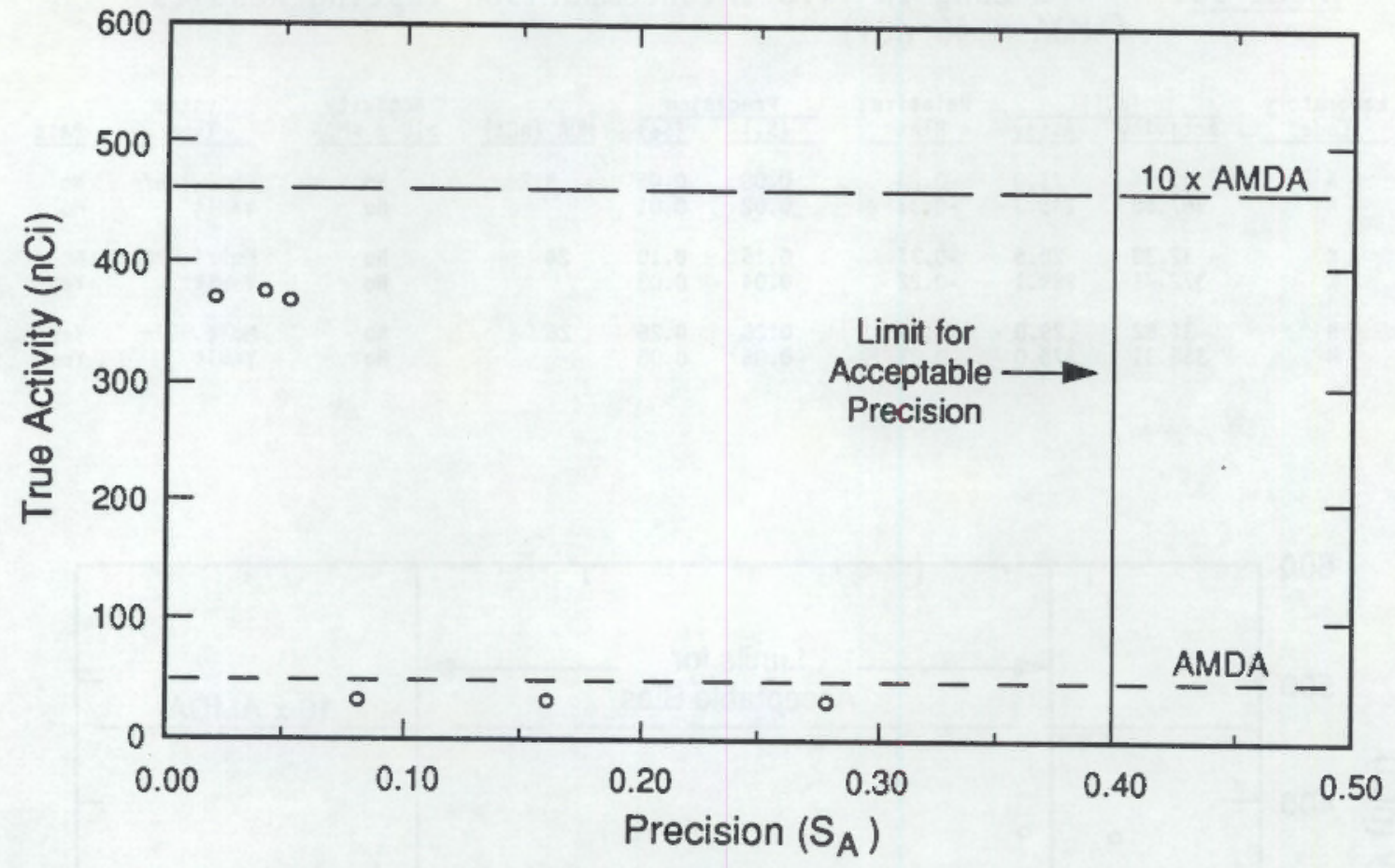

FIGURE 2. ${ }^{238} \mathrm{Pu}$ Precision Statistic $\left(\mathrm{S}_{\mathrm{A}}\right)$ Lung Counting Results

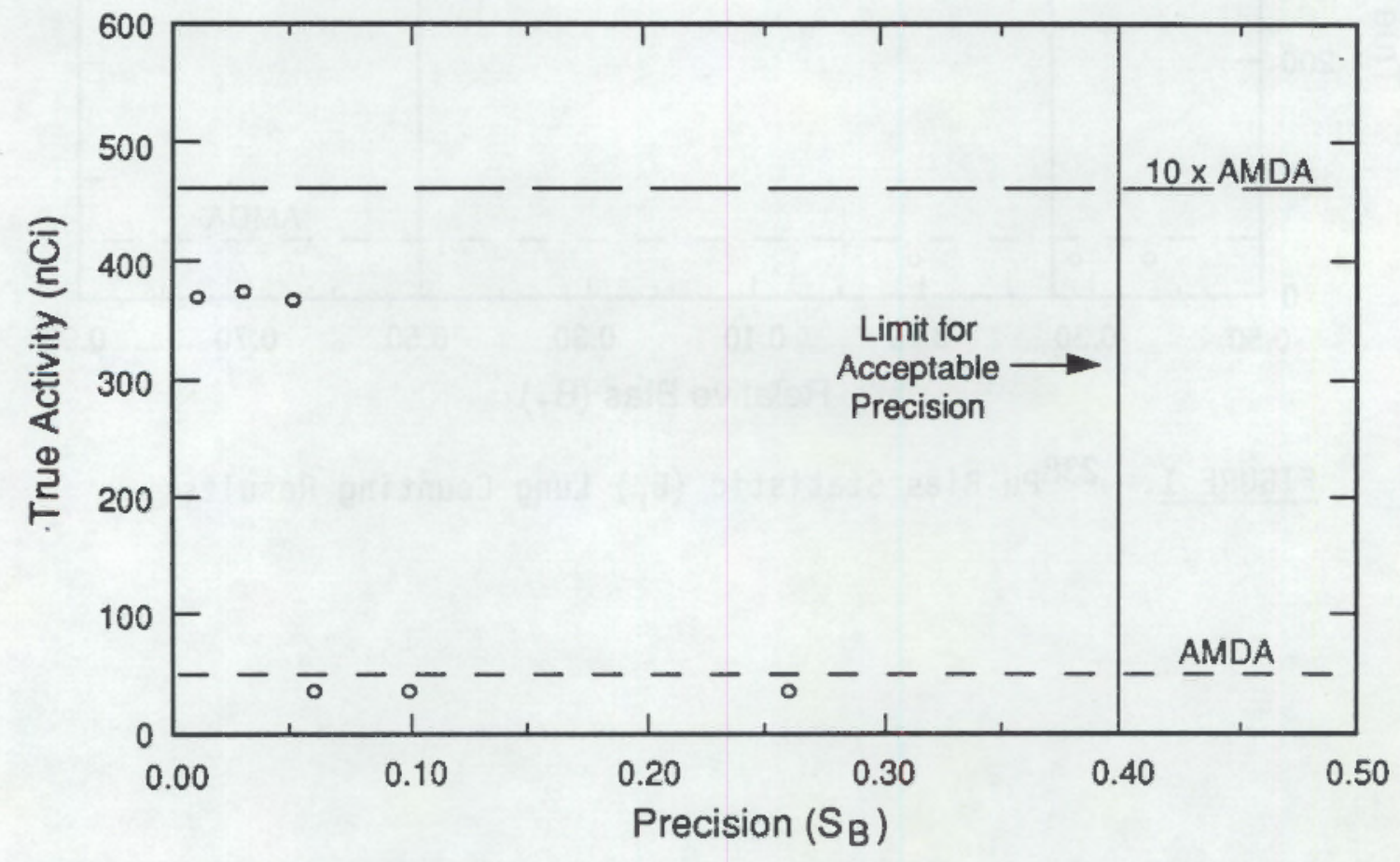

FIGURE 3. $238 \mathrm{pu}$ Precision Statistic $\left(S_{B}\right)$ Lung Counting Results 
TABLE 11. 238 $U$ Lung In Vivo Intercomparison Testing Results (AMAD $=3 \mathrm{nCi}$ )

\begin{tabular}{|c|c|c|c|c|c|c|c|c|c|}
\hline $\begin{array}{c}\text { Laboratory } \\
\text { Code } \\
\end{array}$ & Activity & Assay & $\begin{array}{c}\text { Relative } \\
\text { Bias } \\
\end{array}$ & $\begin{array}{l}\text { Prects } \\
\text { SSN }\end{array}$ & $\frac{10 n}{158}$ & MDA (nCi) & $\begin{array}{r}\text { Activity } \\
\geq 10 \times \text { AMOA } \\
\end{array}$ & $\begin{array}{c}\text { System } \\
\text { Type }\end{array}$ & Pass \\
\hline$\stackrel{A}{A}$ & $\begin{array}{r}3.51 \\
33.07\end{array}$ & $\begin{array}{r}5.0 \\
33.7\end{array}$ & $\begin{array}{l}0.42 \\
0.02\end{array}$ & $\begin{array}{l}0.03 \\
0.02\end{array}$ & $\begin{array}{l}0.04 \\
0.02\end{array}$ & 0.97 & $\begin{array}{l}\text { No } \\
\text { Yes }\end{array}$ & $\begin{array}{l}\text { Phoswich/ } \\
\text { Vault }\end{array}$ & $\begin{array}{l}\text { Yes } \\
\text { Yes }\end{array}$ \\
\hline $\begin{array}{l}\mathbf{K} \\
\mathbf{K}\end{array}$ & $\begin{array}{r}3.51 \\
33.07\end{array}$ & $\begin{array}{c}2.65 \\
29.8\end{array}$ & $\begin{array}{l}-0.24 \\
-0.10\end{array}$ & $\begin{array}{l}0.17 \\
0.04\end{array}$ & $\begin{array}{l}0.13 \\
0.03\end{array}$ & 1.5 & $\begin{array}{l}\text { No } \\
\text { Yes }\end{array}$ & $\begin{array}{l}\text { Mult..HPGe/ } \\
\text { Vault }\end{array}$ & $\begin{array}{l}\text { Yes } \\
\text { Yes }\end{array}$ \\
\hline$N$ & $\begin{array}{r}3.51 \\
33.07\end{array}$ & $\begin{array}{r}3.7 \\
32.0\end{array}$ & $\begin{array}{r}0.05 \\
-0.03\end{array}$ & $\begin{array}{l}0.13 \\
0.00 \text { (a) }\end{array}$ & $\begin{array}{l}0.14 \\
0.07\end{array}$ & 0.90 & $\begin{array}{l}\text { No } \\
\text { Yes }\end{array}$ & $\begin{array}{l}\text { Mult. HPGe/ } \\
\text { Vault }\end{array}$ & $\begin{array}{l}\text { Yes } \\
\text { Yes }\end{array}$ \\
\hline
\end{tabular}

(a) Actual result 0.002 , chi-sequre test passed.

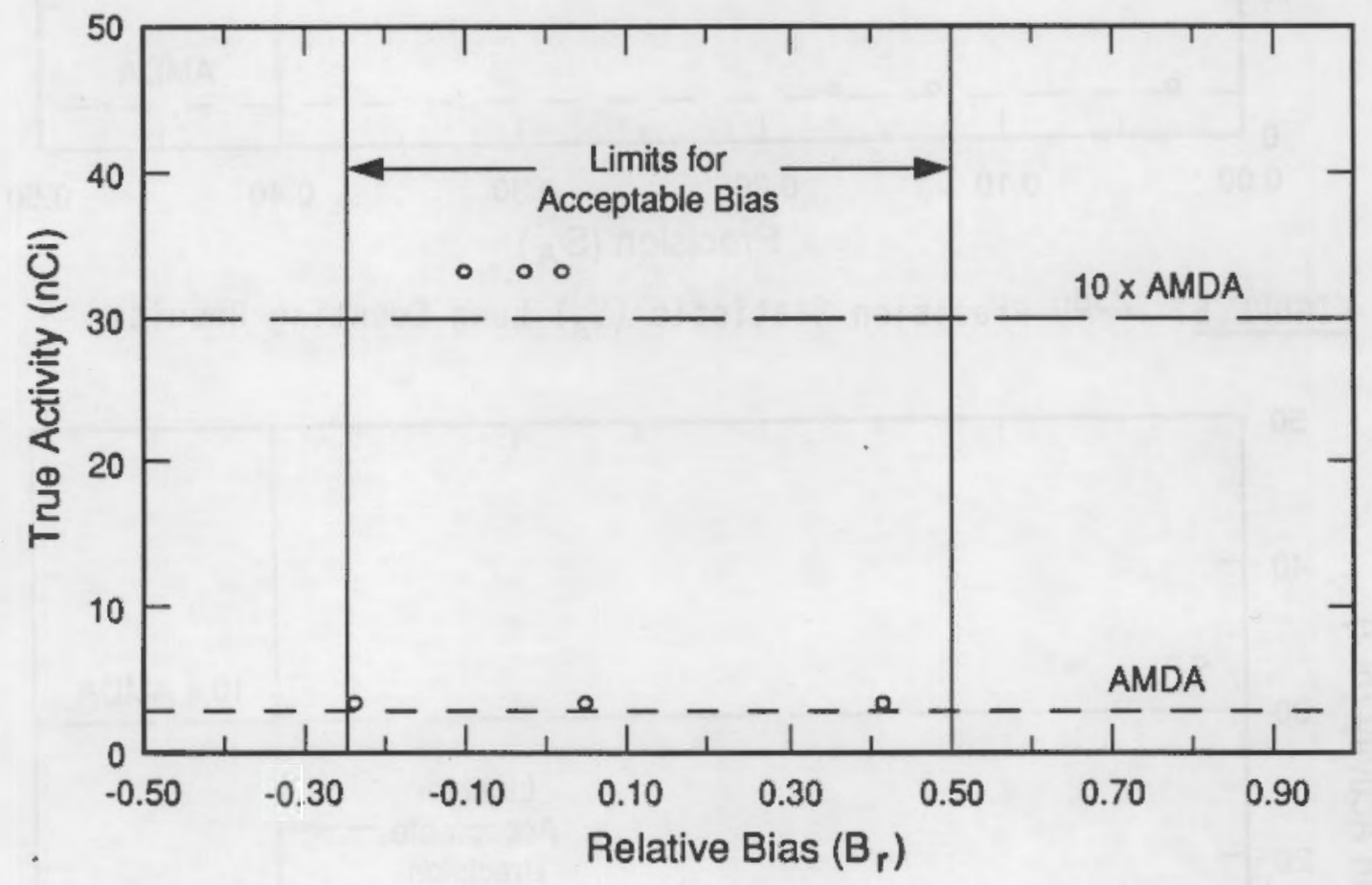

FIGURE 4. $238_{U}$ Bias Statistic $\left(B_{r}\right)$ Lung Counting Results 


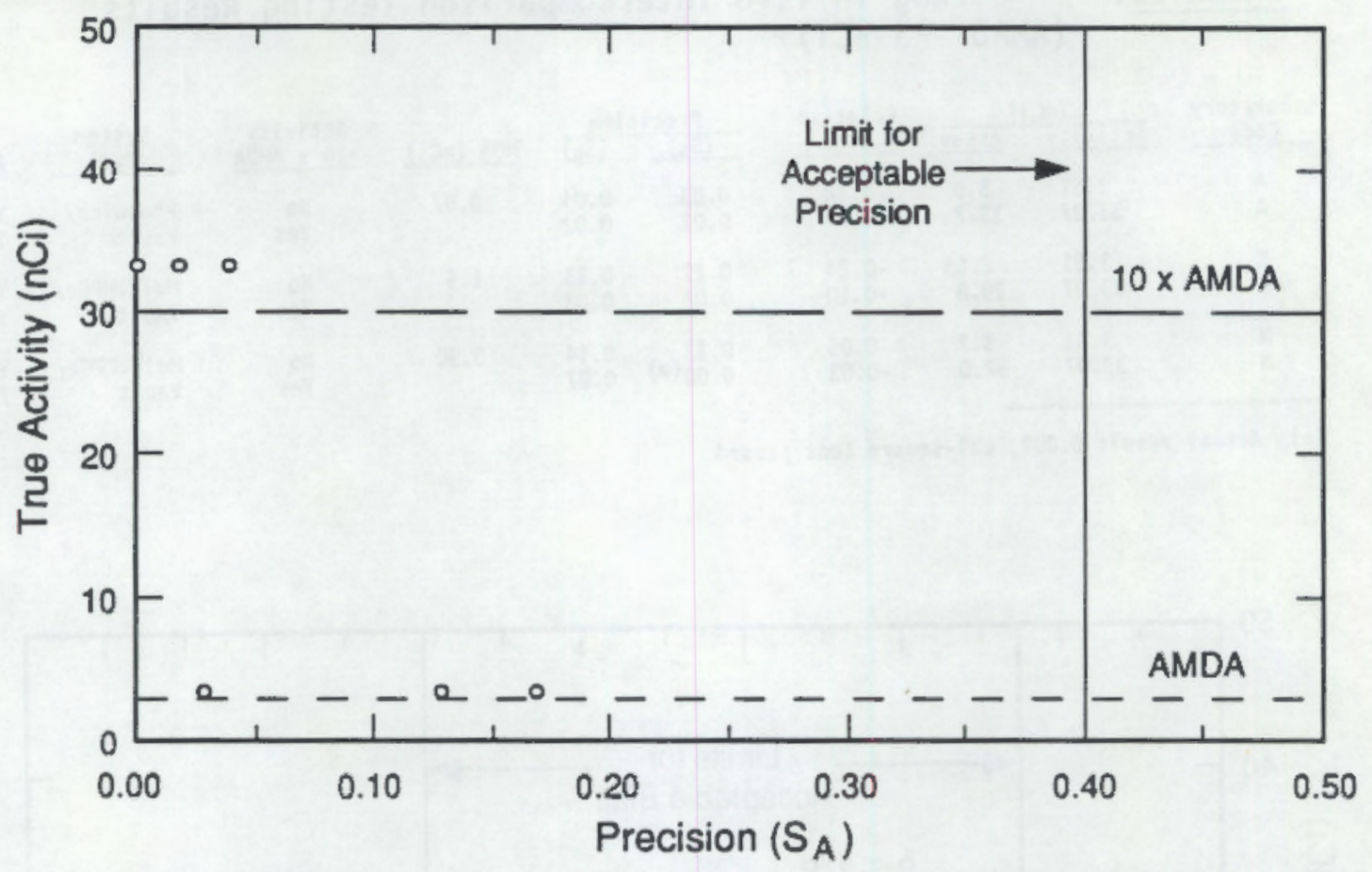

FIGURE 5. $238_{U}$ Precision Statistic $\left(S_{A}\right)$ Lung Counting Results

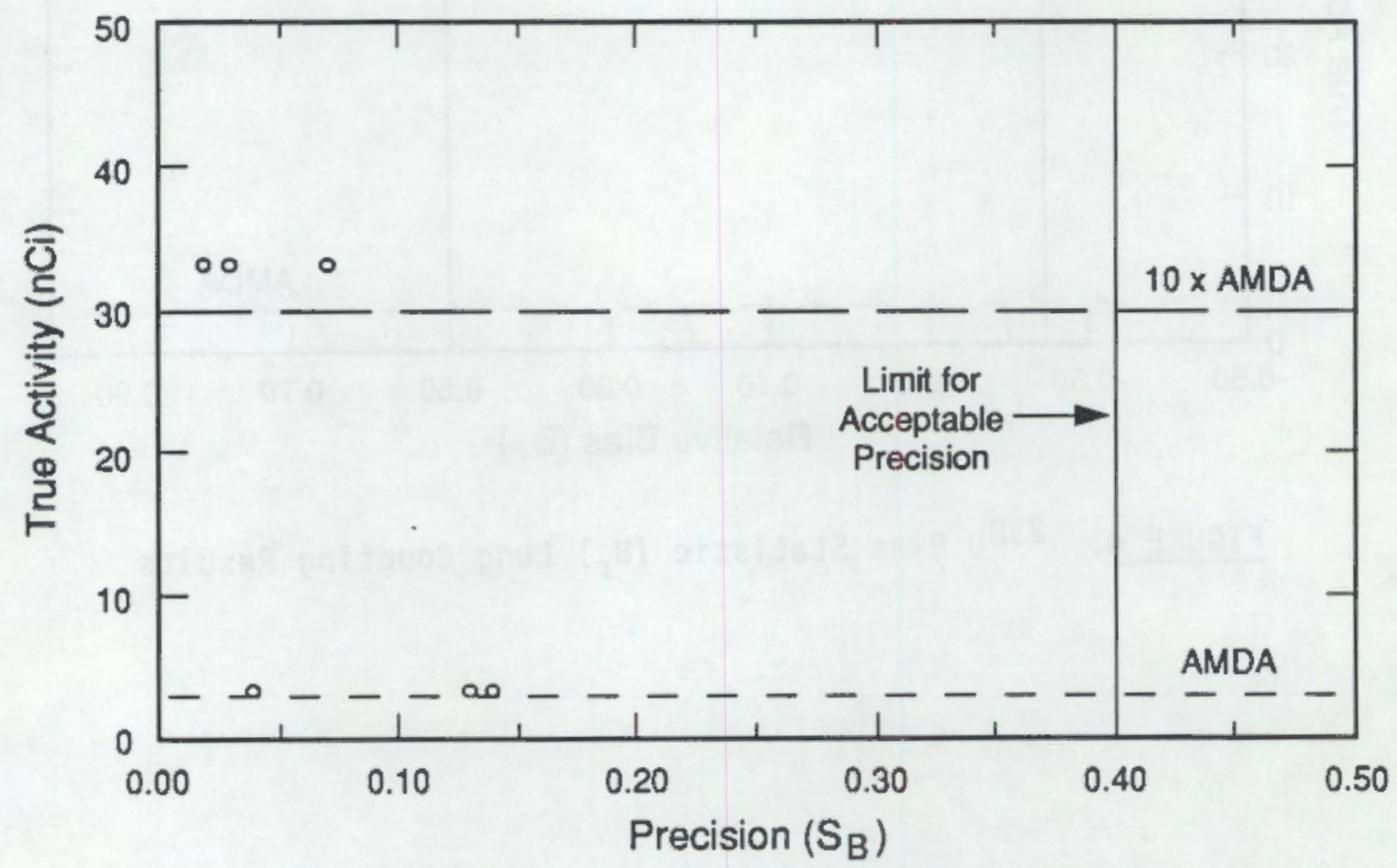

FIGURE 6. ${ }^{238}{ }_{U}$ Precision Statistic $\left(S_{B}\right)$ Lung Counting Results 


\section{TABLE 12. ${ }^{54}$ Mn Lung In Vivo Intercomparison Testing Results (AMDA $=20 \mathrm{nCi}$ )}

\begin{tabular}{|c|c|c|c|c|c|c|c|c|c|}
\hline Laboratory & (nC & & Relative & & & & Activity & System & \\
\hline$A$ & $\begin{array}{r}10.6 \\
107.7\end{array}$ & $\begin{array}{r}7.0 \\
121.7\end{array}$ & $\begin{array}{r}-0.34 \\
0.13\end{array}$ & $\begin{array}{l}0.12 \\
0.00\end{array}$ & $\begin{array}{l}0.08 \\
0.01\end{array}$ & $\begin{array}{l}\text { NC(a) } \\
\text { MC }\end{array}$ & $\begin{array}{l}\text { No } \\
\text { No }\end{array}$ & $\begin{array}{l}\text { Phoswich/ } \\
\text { Vault }\end{array}$ & $\begin{array}{l}\text { No } \\
\text { No }\end{array}$ \\
\hline B2 & 247.8 & 499.8 & 1.02 & 0.23 & 0.47 & $9.9^{(b)}$ & Yes & $\begin{array}{l}\text { (2)MAl/ } \\
\text { Chair }\end{array}$ & No \\
\hline 81 & 247.8 & 316.5 & 0.28 & 0.09 & 0.11 & $7.9(b)$ & Yes & $\mathrm{MAl} / \mathrm{Bed}$ & Yes \\
\hline $\begin{array}{l}c \\
c\end{array}$ & $\begin{array}{l}185.7 \\
226.2\end{array}$ & $\begin{array}{l}108.4 \\
196.6\end{array}$ & $\begin{array}{l}-0.42 \\
-0.13\end{array}$ & $\begin{array}{l}0.23 \\
0.08\end{array}$ & $\begin{array}{l}0.13 \\
0.07\end{array}$ & 3.0 & $\begin{array}{l}\text { Mo } \\
\text { Yes }\end{array}$ & MAI/Bed & $\begin{array}{l}\text { Yes } \\
\text { Yes }\end{array}$ \\
\hline $\begin{array}{l}\text { D1 } \\
D 1 \\
02 \\
D 2 \\
D 3 \\
D 3 \\
D 4 \\
D 4 \\
D 5 \\
D 5 \\
D 6 \\
D 6\end{array}$ & $\begin{array}{r}23.6 \\
240.2 \\
23.5 \\
238.2 \\
23.3 \\
236.6 \\
23.0 \\
234.0 \\
23.0 \\
233.9 \\
22.9 \\
232.9\end{array}$ & $\begin{array}{r}15.4 \\
230.0 \\
134.2 \\
336.2 \\
144.7 \\
370.3 \\
25.6 \\
218.1 \\
26.7 \\
256.8 \\
126.3 \\
304.8\end{array}$ & $\begin{array}{r}-0.35 \\
-0.04 \\
4.71 \\
0.41 \\
5.21 \\
0.57 \\
0.11 \\
-0.07 \\
0.16 \\
0.10 \\
4.51 \\
0.31\end{array}$ & $\begin{array}{l}0.13 \\
0.02 \\
0.01 \\
0.02 \\
0.02 \\
0.02 \\
0.16 \\
0.03 \\
0.20 \\
0.03 \\
0.03 \\
0.03\end{array}$ & $\begin{array}{l}0.09 \\
0.02 \\
0.06 \\
0.02 \\
0.14 \\
0.04 \\
0.18 \\
0.03 \\
0.24 \\
0.03 \\
0.18 \\
0.04\end{array}$ & $\begin{array}{l}M C \\
M C \\
M C \\
M C \\
N C \\
M C \\
13^{(b)} \\
33^{(b)} \\
5.3^{(b)}\end{array}$ & $\begin{array}{l}\text { No } \\
\text { Yes } \\
\text { No } \\
\text { Yes } \\
\text { Ho } \\
\text { Yes } \\
\text { No } \\
\text { Yes } \\
\text { Ho } \\
\text { Yes } \\
\text { No } \\
\text { Yes }\end{array}$ & $\begin{array}{l}\text { MAI/Bed } \\
\text { (2)MAI/ } \\
\text { Chair } \\
\text { (2) MAI/ } \\
\text { Chair } \\
\text { HPGe } \\
\text { HPGe } \\
\text { HPGe } \\
\text { HPGe } \\
\text { MAI/ } \\
\text { Chair }\end{array}$ & $\begin{array}{l}\text { No } \\
\text { Yes } \\
\text { Mo }(d) \\
\text { No } \\
\text { Mo (d) } \\
\text { Mo } \\
\text { Yes } \\
\text { Yes } \\
\text { Yes } \\
\text { Yes } \\
\text { Mo } \\
\text { Yes }\end{array}$ \\
\hline I & $\begin{array}{r}27.9 \\
283.7\end{array}$ & $\begin{array}{r}45.1 \\
453.1\end{array}$ & $\begin{array}{l}0.65 \\
0.60\end{array}$ & $\begin{array}{l}0.13 \\
0.01\end{array}$ & $\begin{array}{l}0.21 \\
0.02\end{array}$ & $\begin{array}{l}\text { NC } \\
\text { NC }\end{array}$ & $\begin{array}{l}\text { No } \\
\text { Yes }\end{array}$ & $\begin{array}{l}\text { MAI/ } \\
\text { Chair }\end{array}$ & $\begin{array}{l}\text { No } \\
\text { No }\end{array}$ \\
\hline $\begin{array}{l}\mathrm{J1} \\
\mathrm{J} 2 \\
\mathrm{J3} \\
\mathrm{J3}\end{array}$ & $\begin{array}{l}246.0 \\
246.0 \\
202.0 \\
246.0\end{array}$ & $\begin{array}{l}445.3 \\
583.1 \\
569.5 \\
705.0\end{array}$ & $\begin{array}{l}0.81 \\
1.37 \\
0.87 \\
1.86\end{array}$ & $\begin{array}{l}0.13 \\
0.10 \\
0.09 \\
0.23\end{array}$ & $\begin{array}{l}0.24 \\
0.36 \\
0.25 \\
0.65\end{array}$ & $\begin{array}{l}7.4 \\
5.1 \\
6.7\end{array}$ & $\begin{array}{l}\text { Yes } \\
\text { Yes } \\
\text { Yes } \\
\text { Yes }\end{array}$ & $\begin{array}{l}\text { (2) MAI/ } \\
\text { Chair } \\
\vdots\end{array}$ & $\begin{array}{l}\text { No } \\
\text { No } \\
\text { No } \\
\text { No }\end{array}$ \\
\hline $\begin{array}{l}K \\
K\end{array}$ & $\begin{array}{l}255.5 \\
209.7\end{array}$ & $\begin{array}{l}210.2 \\
100.2\end{array}$ & $\begin{array}{l}-0.18 \\
-0.52\end{array}$ & $\begin{array}{l}0.05 \\
0.02\end{array}$ & $\begin{array}{l}0.04 \\
0.01\end{array}$ & 0.66 & $\begin{array}{l}\text { Yes } \\
\text { Yes }\end{array}$ & $\begin{array}{l}\text { (2) GeLi/ } \\
\text { ShadowSh }\end{array}$ & $\begin{array}{l}\text { Yes } \\
\text { No }\end{array}$ \\
\hline M1 & 263.1 & 319.1 & 0.21 & 0.05 & 0.06 & HC & Yes & $\mathrm{MAI} / \mathrm{Bed}$ & Yes \\
\hline $\begin{array}{l}\text { M2 } \\
M 2\end{array}$ & $\begin{array}{r}25.8 \\
262.5\end{array}$ & $\begin{array}{l}125.4 \\
329.0\end{array}$ & 0.25 & 0.01 & 0.01 & MC & $\begin{array}{l}\text { No } \\
\text { Yes }\end{array}$ & $\begin{array}{l}\text { Mult.NAI/ } \\
\text { Chair }\end{array}$ & $\begin{array}{l}\mathrm{No}(d) \\
\text { Yes }\end{array}$ \\
\hline $\begin{array}{l}M 3 \\
M 3\end{array}$ & $\begin{array}{r}25.8 \\
262.5\end{array}$ & $\begin{array}{l}130.8 \\
367.4\end{array}$ & 0.4 & 0.01 & 0.02 & NC. & $\begin{array}{l}\text { No } \\
\text { Yes }\end{array}$ & $\begin{array}{l}\text { Mult.MAI/ } \\
\text { Chair }\end{array}$ & $\begin{array}{l}\mathrm{Ho}_{0}(d) \\
\text { Yes }\end{array}$ \\
\hline $\begin{array}{l}M 4 \\
M 4\end{array}$ & $\begin{array}{r}25.5 \\
259.1\end{array}$ & $\begin{array}{l}140.0 \\
366.6\end{array}$ & 0.41 & 0.01 & 0.01 & NC & $\begin{array}{l}\text { Mo } \\
\text { Yes }\end{array}$ & $\begin{array}{l}\text { Multimal/ } \\
\text { Chair }\end{array}$ & $\begin{array}{l}\text { Mo (d) } \\
\text { Yes }\end{array}$ \\
\hline $\begin{array}{l}\text { M5 } \\
\text { M5 }\end{array}$ & $\begin{array}{r}25.5 \\
259.1\end{array}$ & $\begin{array}{l}133.4 \\
265.6\end{array}$ & 0.03 & 0.29 & 0.30 & NC & $\begin{array}{l}\text { No } \\
\text { Yes }\end{array}$ & $\begin{array}{l}\text { Mult1.MAI/ } \\
\text { Chair }\end{array}$ & $\begin{array}{l}\text { No (d) } \\
\text { Yes }\end{array}$ \\
\hline $\begin{array}{l}M 6 \\
M 6\end{array}$ & $\begin{array}{r}25.7 \\
261.9\end{array}$ & $\begin{array}{l}123.0 \\
330.2\end{array}$ & 0.26 & 0.01 & 0.02 & NC & $\begin{array}{l}\text { Mo } \\
\text { Yes }\end{array}$ & $\begin{array}{l}\text { Mult1.MAI/ } \\
\text { Chair }\end{array}$ & $\begin{array}{l}\text { No }(d) \\
\text { Yes }\end{array}$ \\
\hline $\begin{array}{l}\text { M7 } \\
M 7\end{array}$ & $\begin{array}{r}25.7 \\
261.9\end{array}$ & $\begin{array}{l}125.0 \\
351.6\end{array}$ & 0.34 & 0.01 & 0.01 & NC & $\begin{array}{l}\text { Mo } \\
\text { Yes }\end{array}$ & $\begin{array}{l}\text { Multi.NAI/ } \\
\text { Chair }\end{array}$ & $\begin{array}{l}\text { No (d) } \\
\text { Yes }\end{array}$ \\
\hline
\end{tabular}

\footnotetext{
(a) NC = not calculated due to insufficient data.

(b) No blank counting data returned; MDA calculated from AMDA-level phantom.

(c) Lung detector viewing from back.
(d) Misidentified as 58 Co.
} 


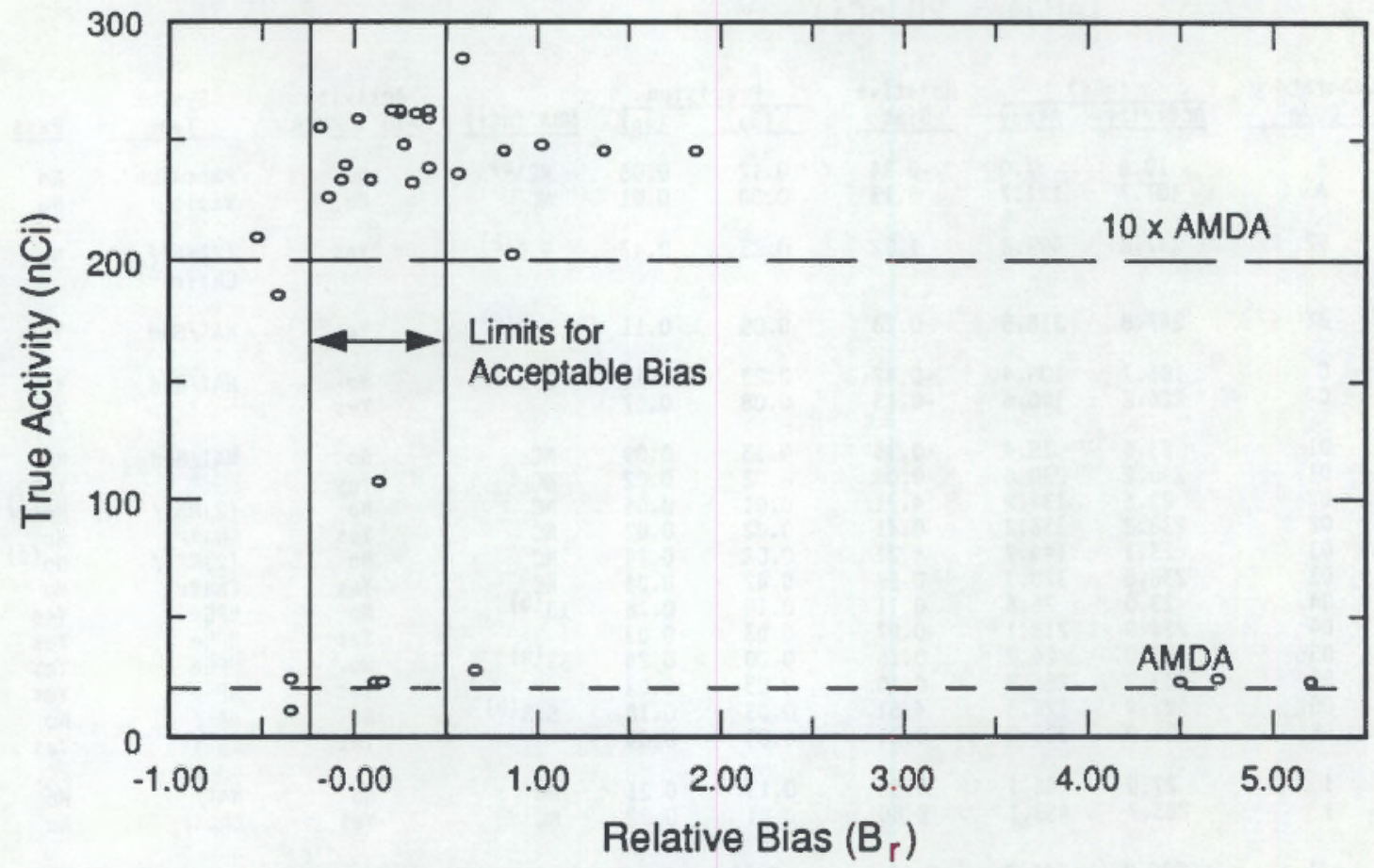

FIGURE 7. ${ }^{54}$ Mn Bias Statistic $\left(B_{r}\right)$ Lung Counting Results

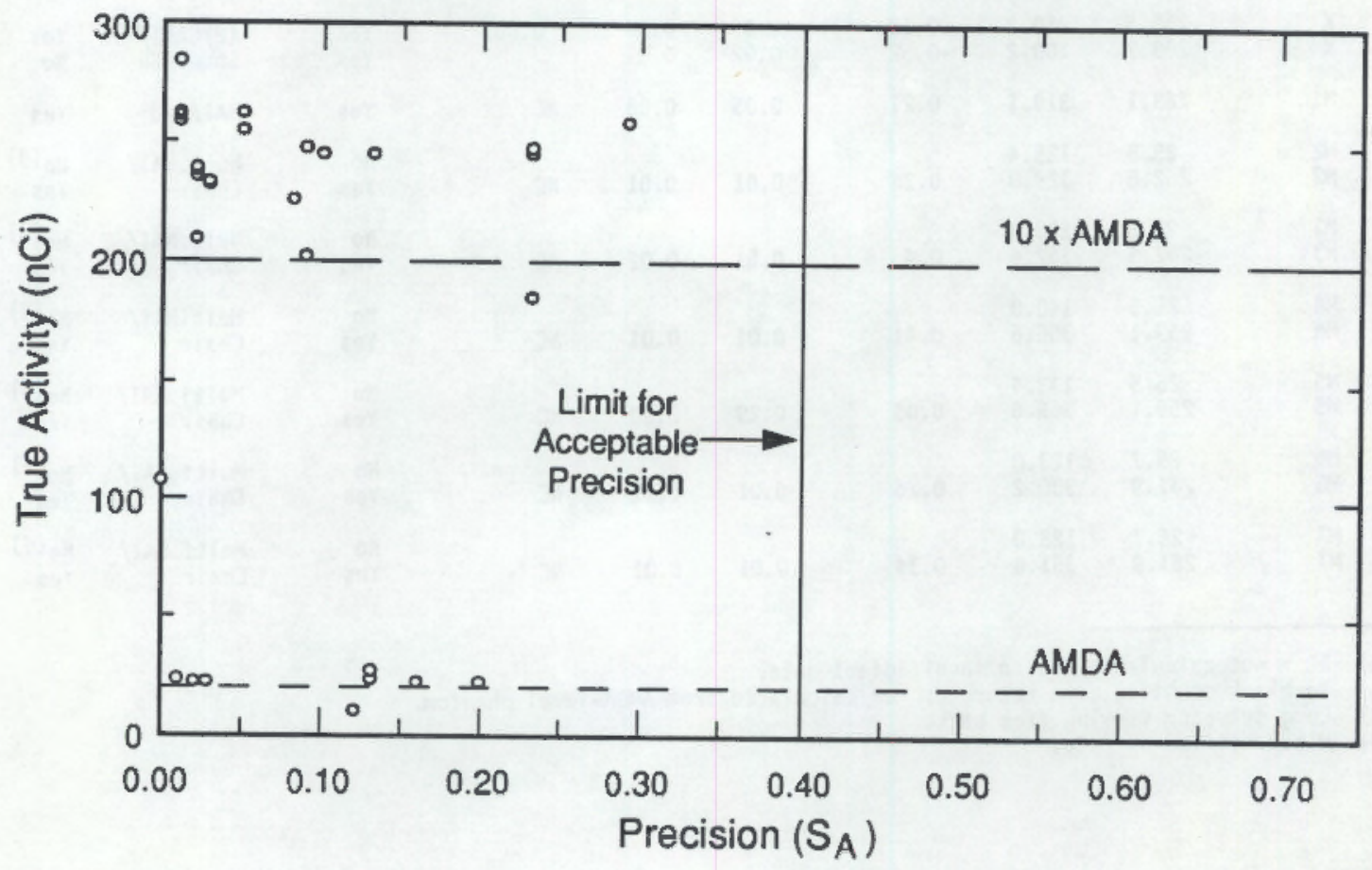

FIGURE 8. ${ }^{54} \mathrm{Mn}$ Precision Statistic $\left(S_{A}\right)$ Lung Counting Results 


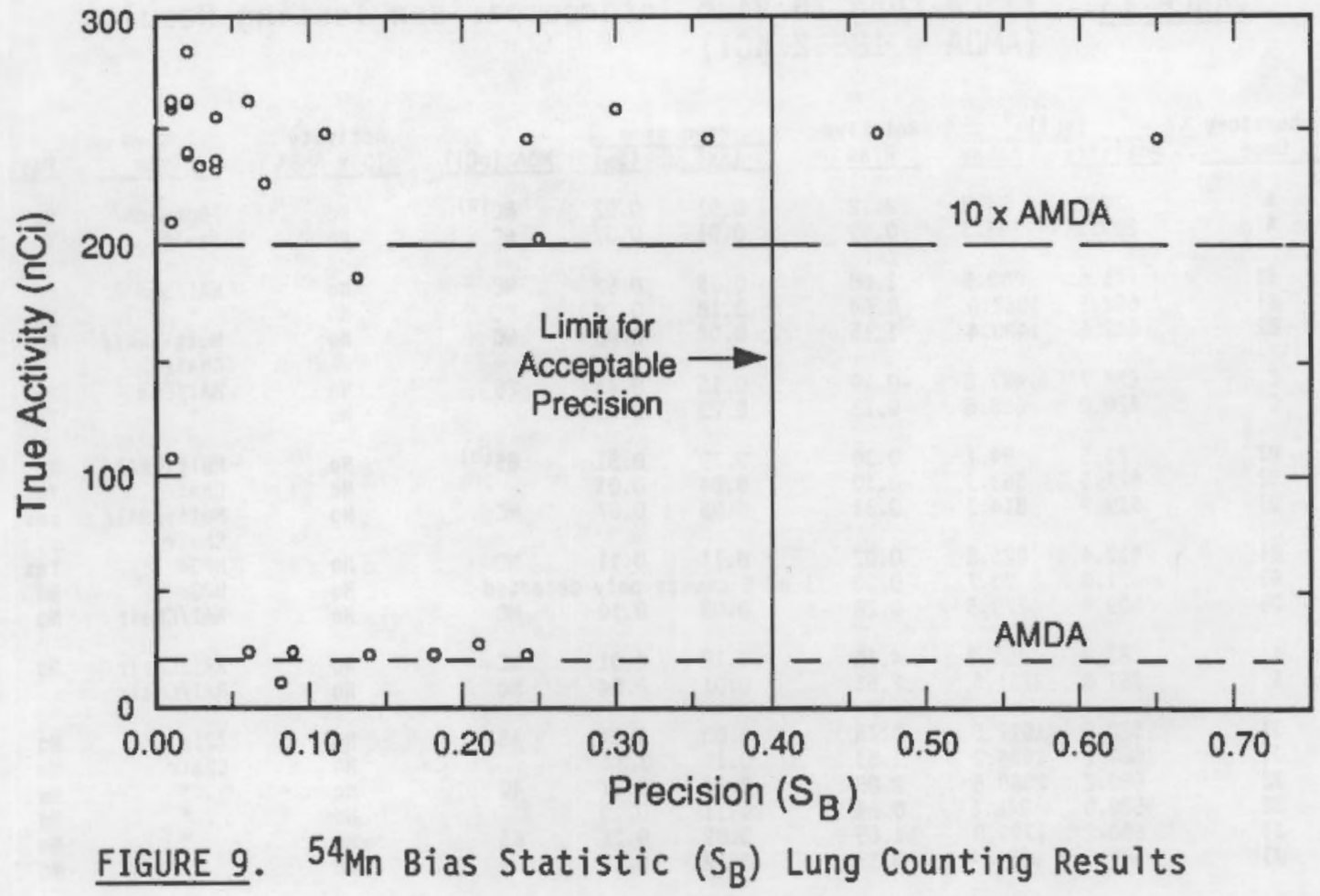




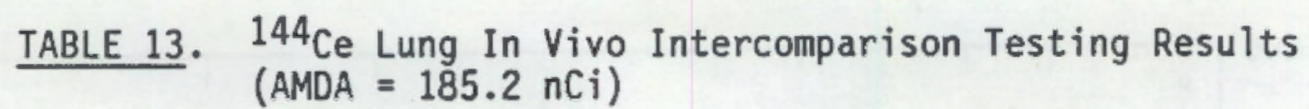

\begin{tabular}{|c|c|c|c|c|c|c|c|c|c|}
\hline $\begin{array}{c}\text { Laboratory } \\
\text { Code }\end{array}$ & $\frac{\operatorname{lnC}}{\text { Activity }}$ & i) & $\begin{array}{c}\text { Relative } \\
\text { Bias }\end{array}$ & $\frac{\text { Precisi }}{\left(S_{A}\right)}$ & $\frac{10 n}{\left(S_{B}\right)}$ & MDA (nCi) & $\begin{array}{c}\text { Activity } \\
>10 \times \text { AMDA }\end{array}$ & $\begin{array}{l}\text { System } \\
\text { Type }\end{array}$ & Pass \\
\hline A & $\begin{array}{r}30.2 \\
260.9\end{array}$ & $\begin{array}{r}94.3 \\
388.3\end{array}$ & $\begin{array}{l}2.12 \\
0.49\end{array}$ & $\begin{array}{l}0.01 \\
0.01\end{array}$ & $\begin{array}{l}0.02 \\
0.02\end{array}$ & $\begin{array}{l}\mathrm{NC}(\mathrm{a}) \\
\mathrm{NC}\end{array}$ & $\begin{array}{l}\text { No } \\
\text { No }\end{array}$ & $\begin{array}{l}\text { Phoswich/ } \\
\text { Vault }\end{array}$ & $\begin{array}{l}\text { No } \\
\text { Yes }\end{array}$ \\
\hline $\begin{array}{l}81 \\
B 1 \\
B 2\end{array}$ & $\begin{array}{r}75.6 \\
652.5 \\
652.5\end{array}$ & $\begin{array}{r}202.5 \\
1067.0 \\
1400.4\end{array}$ & $\begin{array}{l}1.68 \\
0.64 \\
1.15\end{array}$ & $\begin{array}{l}0.35 \\
0.18 \\
0.04\end{array}$ & $\begin{array}{l}0.92 \\
0.29 \\
0.08\end{array}$ & $\begin{array}{l}\text { MC } \\
\text { NC } \\
\text { MC }\end{array}$ & $\begin{array}{l}\text { No } \\
\text { No } \\
\text { No }\end{array}$ & $\begin{array}{l}\text { MAI/Bed } \\
\text { Multi.MAI/ } \\
\text { Chair }\end{array}$ & $\begin{array}{l}\text { No } \\
\text { No } \\
\text { No }\end{array}$ \\
\hline $\begin{array}{l}C \\
C\end{array}$ & $\begin{array}{l}528.7 \\
620.0\end{array}$ & $\begin{array}{l}427.6 \\
698.6\end{array}$ & $\begin{array}{r}-0.19 \\
0.13\end{array}$ & $\begin{array}{l}0.16 \\
0.20\end{array}$ & $\begin{array}{l}0.13 \\
0.23\end{array}$ & 26 & $\begin{array}{l}\text { No } \\
\text { No }\end{array}$ & MAI/Bed & $\begin{array}{l}\text { Yes } \\
\text { Yes }\end{array}$ \\
\hline $\begin{array}{l}\text { D2 } \\
\text { D2 } \\
\text { D3 }\end{array}$ & $\begin{array}{r}75.5 \\
624.5 \\
619.9\end{array}$ & $\begin{array}{r}94.1 \\
563.3 \\
814.3\end{array}$ & $\begin{array}{r}0.30 \\
-0.10 \\
0.31\end{array}$ & $\begin{array}{l}0.39 \\
0.04 \\
0.05\end{array}$ & $\begin{array}{l}0.51 \\
0.03 \\
0.07\end{array}$ & $\begin{array}{l}65 \text { (b) } \\
\text { NC }\end{array}$ & $\begin{array}{l}\text { No } \\
\text { No } \\
\text { No }\end{array}$ & $\begin{array}{l}\text { Multi.NAI/ } \\
\text { Chair } \\
\text { Multi.NAI/ } \\
\text { Chair }\end{array}$ & $\begin{array}{l}\text { No } \\
\text { Yes } \\
\text { Yes }\end{array}$ \\
\hline $\begin{array}{l}\text { D4 } \\
\text { D5 } \\
\text { D6 }\end{array}$ & $\begin{array}{r}612.4 \\
71.0 \\
609.4\end{array}$ & $\begin{array}{r}625.8 \\
70.7 \\
779.5\end{array}$ & $\begin{array}{l}0.02 \\
0.00 \\
0.28\end{array}$ & 1 of $\begin{array}{l}0.11 \\
5 \text { counts } \\
0.08\end{array}$ & $\begin{array}{l}0.11 \\
\text { only } \\
0.10\end{array}$ & $\begin{array}{c}\text { NC } \\
\text { detected } \\
\text { NC }\end{array}$ & $\begin{array}{l}\text { No } \\
\text { No } \\
\text { No }\end{array}$ & $\begin{array}{l}\text { HPGe } \\
\text { HPGe } \\
\text { NAI/Chair }\end{array}$ & $\begin{array}{l}\text { Yes } \\
\text { No } \\
\text { No }\end{array}$ \\
\hline I & $\begin{array}{r}87.9 \\
757.8\end{array}$ & $\begin{array}{r}456.2 \\
2731.6\end{array}$ & $\begin{array}{l}4.18 \\
2.61\end{array}$ & $\begin{array}{l}0.18 \\
0.01\end{array}$ & $\begin{array}{l}0.91 \\
0.04\end{array}$ & $\begin{array}{l}\text { NC } \\
\text { NC }\end{array}$ & $\begin{array}{l}\text { No } \\
\text { No }\end{array}$ & $\begin{array}{l}\text { MAI/Chair } \\
\text { MAI/Chair }\end{array}$ & No \\
\hline $\begin{array}{l}\mathrm{J} 1 \\
\mathrm{~J} 1 \\
\mathrm{~J} 2 \\
\mathrm{~J} 2 \\
\mathrm{J3} \\
\mathrm{J} 3\end{array}$ & $\begin{array}{l}580.0 \\
680.2 \\
680.2 \\
580.0 \\
680.2 \\
580.0\end{array}$ & $\begin{array}{r}1017.6 \\
1924.2 \\
2080.6 \\
948.6 \\
1799.8 \\
881.4\end{array}$ & $\begin{array}{l}0.75 \\
1.83 \\
2.06 \\
0.64 \\
1.65 \\
0.52\end{array}$ & $\begin{array}{l}0.08 \\
0.11 \\
0.12 \\
0.11 \\
0.09 \\
0.12\end{array}$ & $\begin{array}{l}0.14 \\
0.32 \\
0.37 \\
0.19 \\
0.25 \\
0.18\end{array}$ & $\begin{array}{l}48 \\
40\end{array}$ & $\begin{array}{l}\text { No } \\
\text { No } \\
\text { No } \\
\text { No } \\
\text { No } \\
\text { No }\end{array}$ & $\begin{array}{l}\text { (2)NAI/ } \\
\text { Chair }\end{array}$ & $\begin{array}{l}\text { No } \\
\text { No } \\
\text { No } \\
\text { No } \\
\text { No } \\
\text { No }\end{array}$ \\
\hline $\begin{array}{l}x \\
K\end{array}$ & $\begin{array}{l}604.57 \\
709.07\end{array}$ & $\begin{array}{l}312.8 \\
570.8\end{array}$ & $\begin{array}{l}-0.48 \\
-0.20\end{array}$ & $\begin{array}{l}0.02 \\
0.07\end{array}$ & $\begin{array}{l}0.01 \\
0.05\end{array}$ & 7.9 & $\begin{array}{l}\text { No } \\
\text { No }\end{array}$ & $\begin{array}{l}\text { (2)GeLi/ } \\
\text { ShadowSh }\end{array}$ & $\begin{array}{l}\text { No } \\
\text { Yes }\end{array}$ \\
\hline $\begin{array}{l}\text { M1 } \\
\text { MI }\end{array}$ & $\begin{array}{r}80.79 \\
696.95\end{array}$ & $\begin{array}{r}226.3 \\
1565.2\end{array}$ & $\begin{array}{l}1.80 \\
1.25\end{array}$ & $\begin{array}{l}0.25 \\
0.03\end{array}$ & $\begin{array}{l}0.71 \\
0.08\end{array}$ & $\begin{array}{l}\text { NC } \\
\text { NC }\end{array}$ & $\begin{array}{l}\text { No } \\
\text { No }\end{array}$ & $\mathrm{MAI} / \mathrm{Bed}$ & $\begin{array}{l}\text { No } \\
\text { No }\end{array}$ \\
\hline $\begin{array}{l}\text { MR } \\
M 2\end{array}$ & $\begin{array}{c}80.5 \\
695.25\end{array}$ & $\begin{array}{l}110.3 \\
790.6\end{array}$ & $\begin{array}{l}0.37 \\
0.14\end{array}$ & $\begin{array}{l}0.51 \\
0.08\end{array}$ & $\begin{array}{l}0.69 \\
0.09\end{array}$ & ${ }_{43}(\mathrm{~b})$ & $\begin{array}{l}\text { No } \\
\text { No }\end{array}$ & $\begin{array}{l}\text { Multi.MAI/ } \\
\text { Chair }\end{array}$ & $\begin{array}{l}\text { No } \\
\text { Yes }\end{array}$ \\
\hline $\begin{array}{l}M 3 \\
M 3\end{array}$ & $\begin{array}{l}80.59 \\
695.25\end{array}$ & $\begin{array}{r}87.3 \\
531.8\end{array}$ & $\begin{array}{r}0.08 \\
-0.24\end{array}$ & $\begin{array}{l}0.59 \\
0.06\end{array}$ & $\begin{array}{l}0.64 \\
0.04\end{array}$ & $45^{\text {(b) }}$ & $\begin{array}{l}\text { No } \\
\text { No }\end{array}$ & $\begin{array}{l}\text { Multi.MAI/ } \\
\text { Chair }\end{array}$ & $\begin{array}{l}\text { No } \\
\text { Yes }\end{array}$ \\
\hline M4 & 685.15 & 864.4 & 0.26 & 0.36 & 0.46 & NC & No & " & No \\
\hline $\begin{array}{l}\text { M5 } \\
\text { M5 }\end{array}$ & $\begin{array}{r}79.42 \\
685.15\end{array}$ & $\begin{array}{r}70.7 \\
668.0\end{array}$ & $\begin{array}{l}-0.11 \\
-0.03\end{array}$ & $\begin{array}{l}0.17 \\
0.07\end{array}$ & $\begin{array}{l}0.15 \\
0.07\end{array}$ & 66 (b) & $\begin{array}{l}\text { No } \\
\text { No }\end{array}$ & $\begin{array}{l}\text { MultiMAI/ } \\
\text { Chair }\end{array}$ & $\begin{array}{l}\text { Yes } \\
\text { Yes }\end{array}$ \\
\hline $\begin{array}{l}\text { M6 } \\
146\end{array}$ & $\begin{array}{r}80.40 \\
693.56\end{array}$ & $\begin{array}{r}97.7 \\
487.8\end{array}$ & $\begin{array}{r}0.21 \\
-0.30\end{array}$ & $\begin{array}{l}0.39 \\
0.08\end{array}$ & $\begin{array}{l}0.47 \\
0.05\end{array}$ & $46^{\text {(b) }}$ & $\begin{array}{l}\text { No } \\
\text { No }\end{array}$ & $\begin{array}{l}\text { MultiNAI/ } \\
\text { Chair }\end{array}$ & $\begin{array}{l}\text { No } \\
\text { No }\end{array}$ \\
\hline $\begin{array}{l}\text { M7 } \\
\text { M7 }\end{array}$ & $\begin{array}{r}80.40 \\
693.56\end{array}$ & $\begin{array}{r}63.0 \\
654.8\end{array}$ & $\begin{array}{l}-0.22 \\
-0.06\end{array}$ & $\begin{array}{l}0.26 \\
0.10\end{array}$ & $\begin{array}{l}0.21 \\
0.10\end{array}$ & 55 & $\begin{array}{l}\text { No } \\
\text { No }\end{array}$ & $\begin{array}{l}\text { MultikAI/ } \\
\text { Chair }\end{array}$ & $\begin{array}{l}\text { Yes } \\
\text { Yes }\end{array}$ \\
\hline
\end{tabular}

(a) $N C=$ Not calculated due to insufficient data.

(b) No blank count information given, MDA calculated from low spike lung set. 


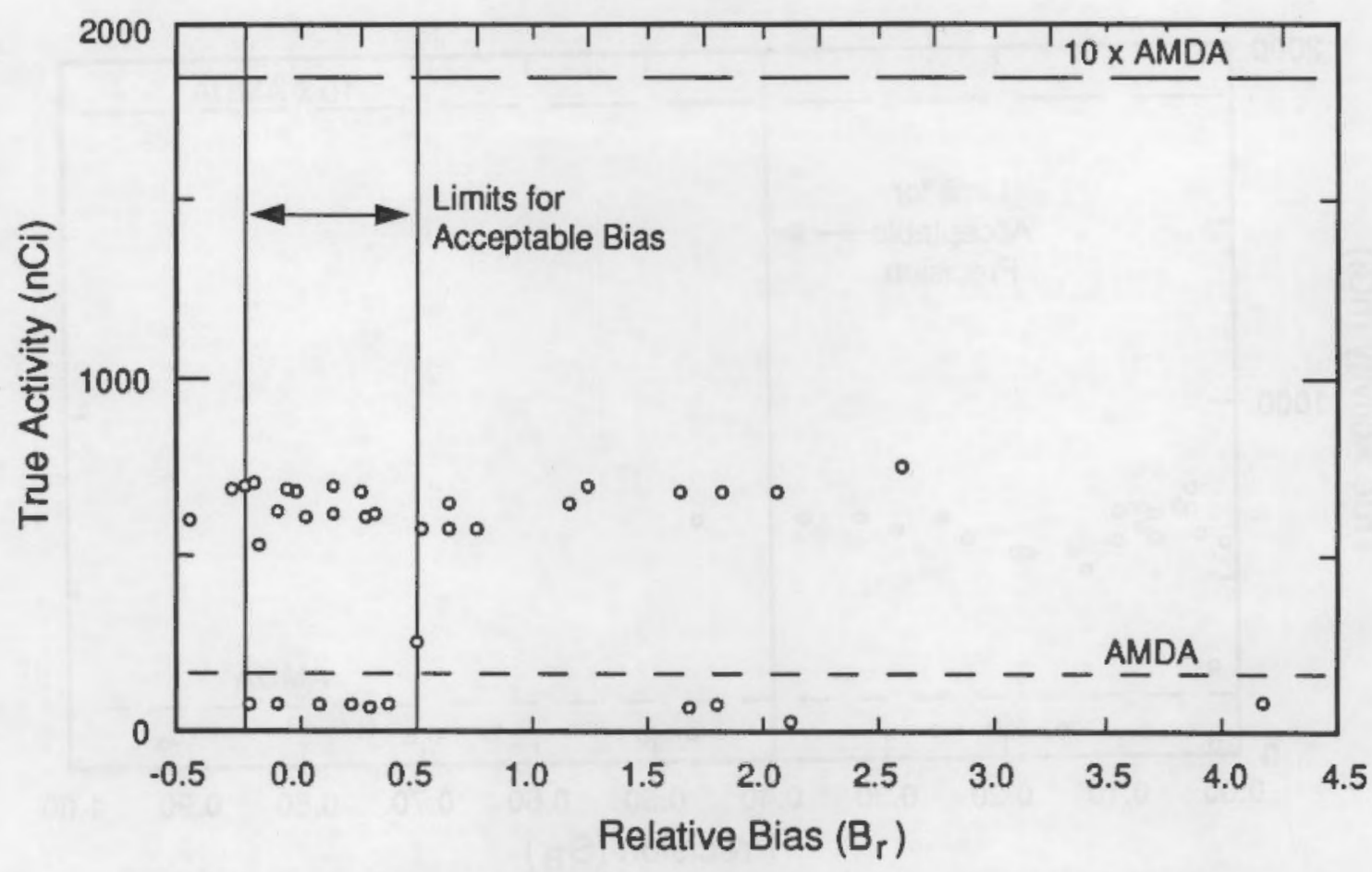

FIGURE 10. ${ }^{144} \mathrm{Ce}$ Bias Statistic $\left(B_{r}\right)$ Lung Counting Results

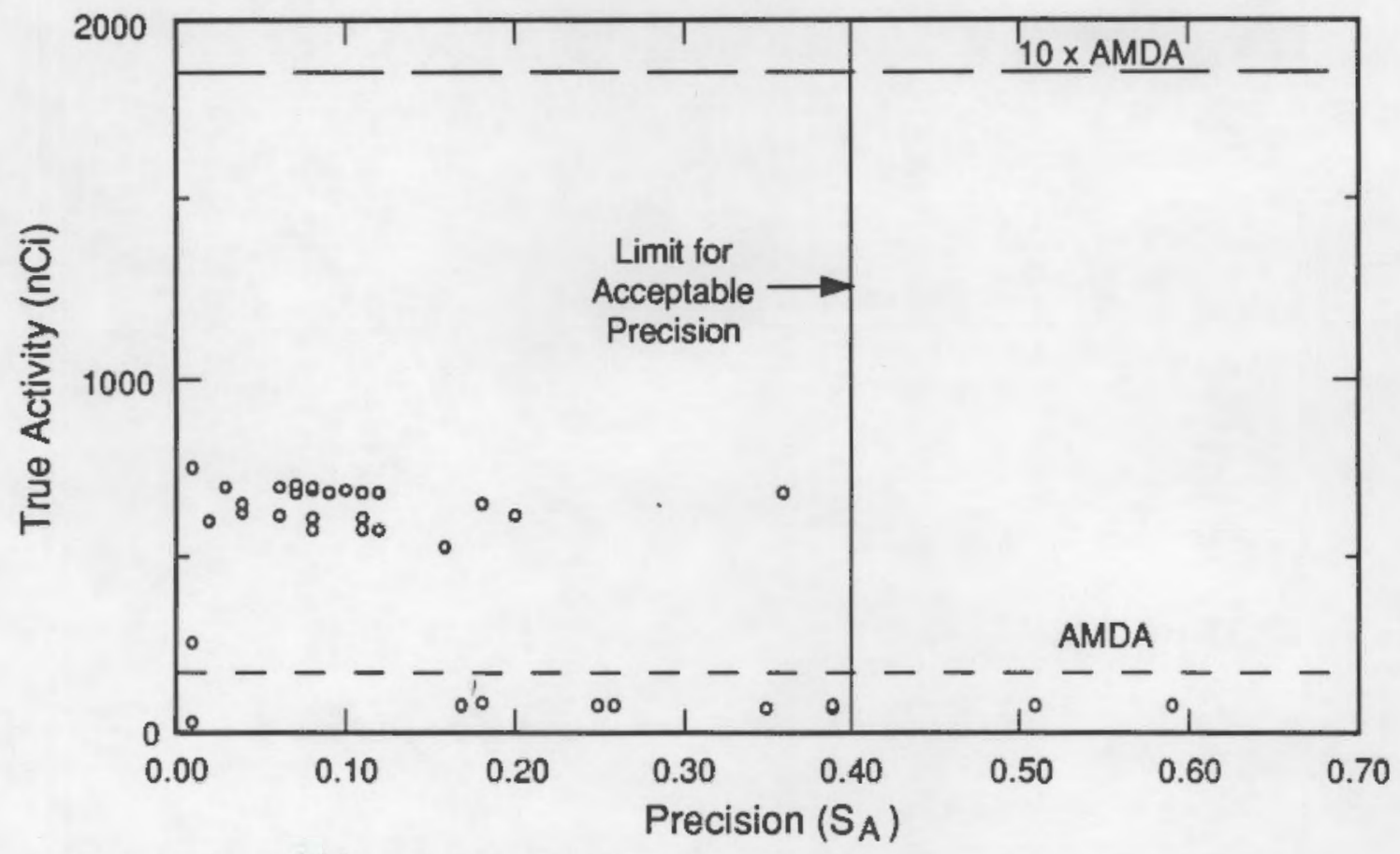

FIGURE 11. ${ }^{144}$ Ce Precision Statistic $\left(S_{A}\right)$ Lung Counting Results 


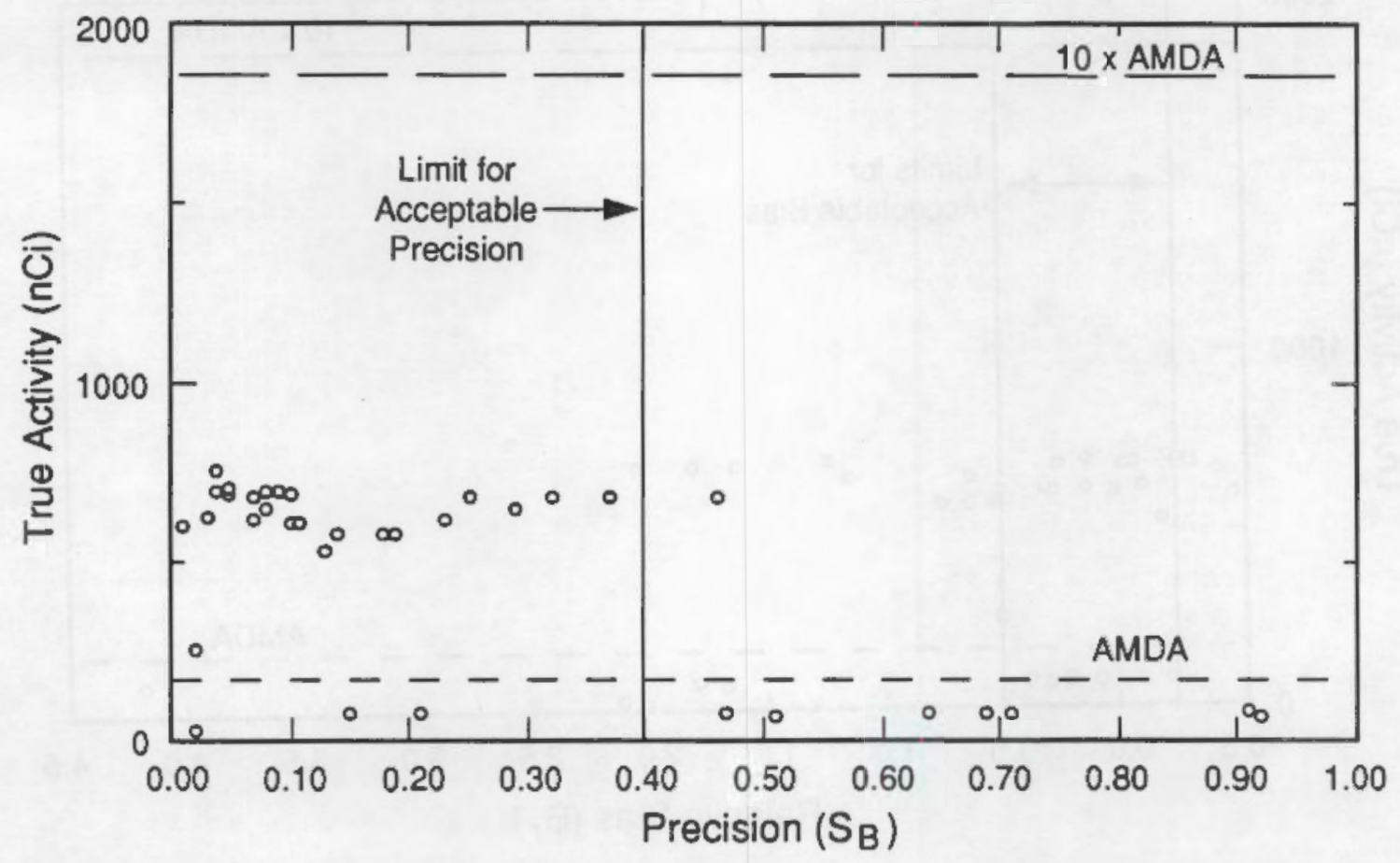

FIGURE $12 .{ }^{144} \mathrm{Ce}$ Precision Statistic $\left(S_{B}\right)$ Lung Counting Results 
TABLE 14. ${ }^{137}$ Cs Whole Body In Vivo Intercomparison Testing Results (AMDA $=24 \mathrm{nCi}$ )

\begin{tabular}{|c|c|c|c|c|c|c|c|c|c|}
\hline Laboratory & $\operatorname{lnc}$ & & Relative & Preci & ion & & $\begin{array}{l}\text { Activity } \\
>10 \times A M D A\end{array}$ & $\begin{array}{c}\text { System } \\
\text { Type }\end{array}$ & Pass \\
\hline & Activity & Assay & Bias & $\left(S_{A}\right)$ & $\underline{\left(S_{B}\right)}$ & MOA (nCi) & & & pass \\
\hline $\begin{array}{l}\text { A } \\
81 \\
B 2\end{array}$ & $\begin{array}{l}343.77 \\
354.56 \\
354.56\end{array}$ & $\begin{array}{l}261.8 \\
412.6 \\
238.8\end{array}$ & $\begin{array}{r}-0.24 \\
0.16 \\
-0.33\end{array}$ & $\begin{array}{l}0.06 \\
0.08 \\
0.07\end{array}$ & $\begin{array}{l}0.04 \\
0.10 \\
0.11\end{array}$ & $\begin{array}{l}M C(a) \\
N C \\
M C\end{array}$ & $\begin{array}{l}\text { Yes } \\
\text { Yes } \\
\text { Yes }\end{array}$ & $\begin{array}{l}\text { (2)NAI } \\
\text { NAI/bed } \\
\text { (3)NAI/ } \\
\text { Chair }\end{array}$ & $\begin{array}{l}\text { Yes } \\
\text { Yes } \\
\text { Ho }\end{array}$ \\
\hline $\begin{array}{l}G \\
\text { G1 }\end{array}$ & $\begin{array}{l}350.67 \\
350.67\end{array}$ & $\begin{array}{l}349.0 \\
336.8\end{array}$ & $\begin{array}{l}-0.00 \\
-0.04\end{array}$ & $\begin{array}{l}0.01 \\
0.01\end{array}$ & $\begin{array}{l}0.01 \\
0.01\end{array}$ & $M C^{4.5}$ & $\begin{array}{l}\text { Yes } \\
\text { Yes }\end{array}$ & NAI/Chair & $\begin{array}{l}\text { Yes } \\
\text { Yes }\end{array}$ \\
\hline I & 355.20 & 454.2 & 0.28 & 0.08 & 0.10 & NC & Yes & NAI/Chair & Yes \\
\hline J1 & 358.5 & 417.2 & 0.16 & 0.04 & 0.05 & 14 & Yes & $\begin{array}{l}\text { (2) MAII/ } \\
\text { Chair }\end{array}$ & Yes \\
\hline $\begin{array}{l}\mathrm{J} 2 \\
\mathrm{j} 3\end{array}$ & $\begin{array}{l}358.5 \\
358.5\end{array}$ & $\begin{array}{l}284.0 \\
233.7\end{array}$ & $\begin{array}{l}-0.21 \\
-0.35\end{array}$ & $\begin{array}{l}0.41 \\
0.11\end{array}$ & $\begin{array}{l}0.32 \\
0.07\end{array}$ & $\begin{array}{l}21 \\
29\end{array}$ & $\begin{array}{l}\text { Yes } \\
\text { Yes }\end{array}$ & " & $\begin{array}{l}\text { No } \\
\text { Ho }\end{array}$ \\
\hline L & 340.71 & 348.0 & 0.02 & 0.09 & 0.09 & 14. & Yes & $\begin{array}{l}\text { CoaxGeLi/ } \\
\text { Chair }\end{array}$ & Yes \\
\hline M1 & 354.18 & 386.3 & 0.08 & 0.03 & 0.04 & MC & Yes & MAI/Bed & Yes \\
\hline
\end{tabular}

(a) NC = Not calculated due to insufficient data.

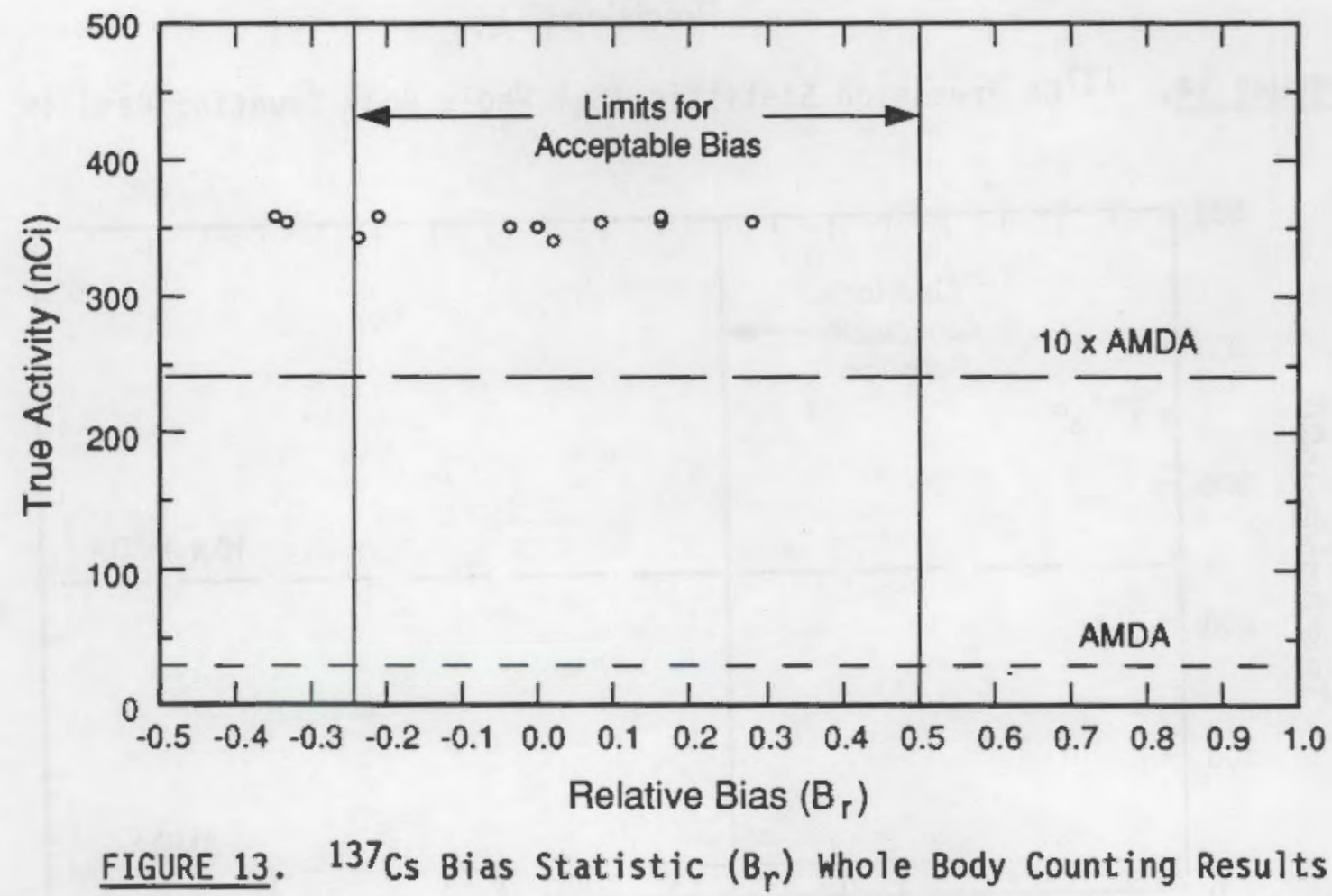




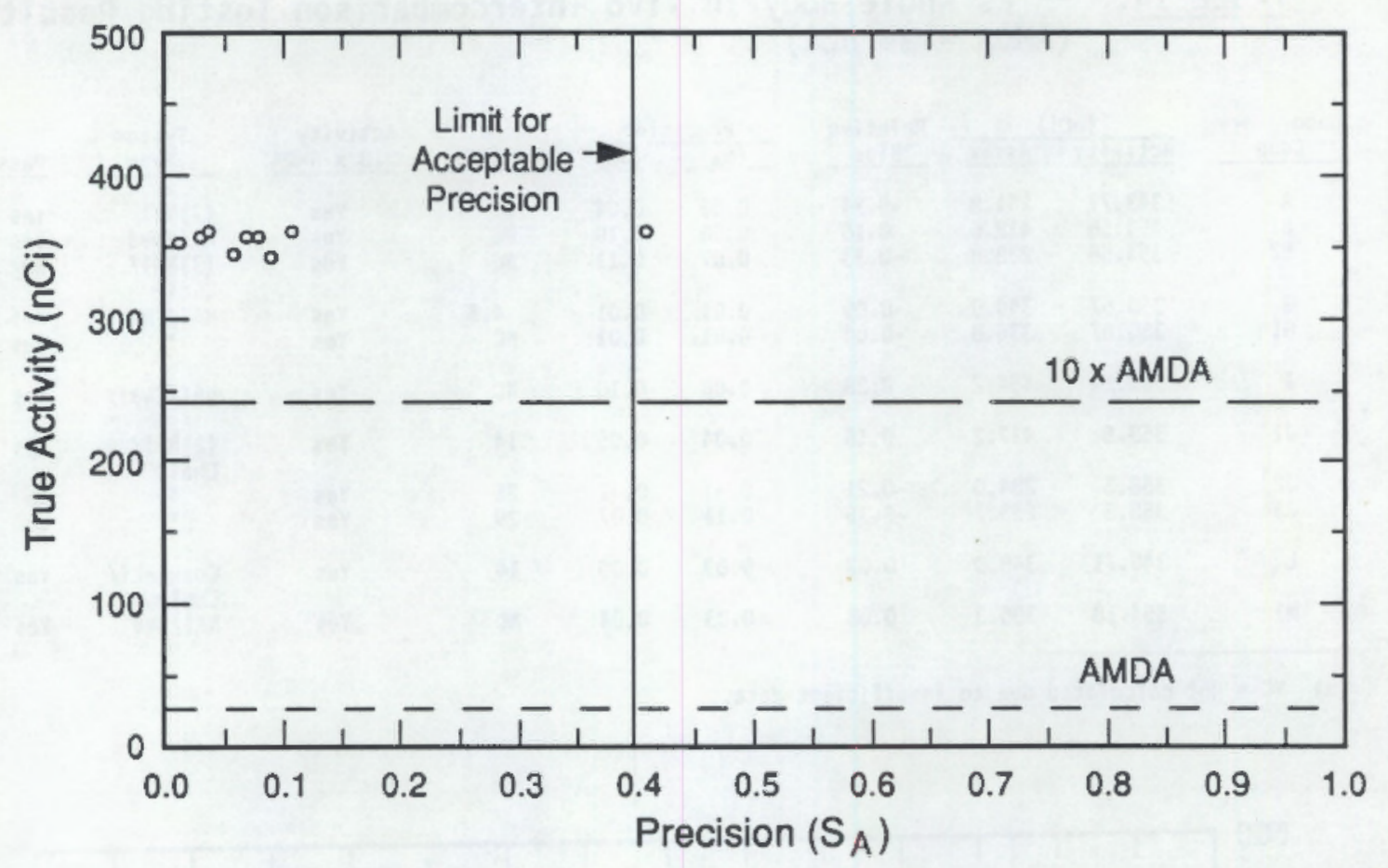

FIGURE $14 .{ }^{137}$ Cs Precision Statistic $\left(S_{A}\right)$ Whole Body Counting Results

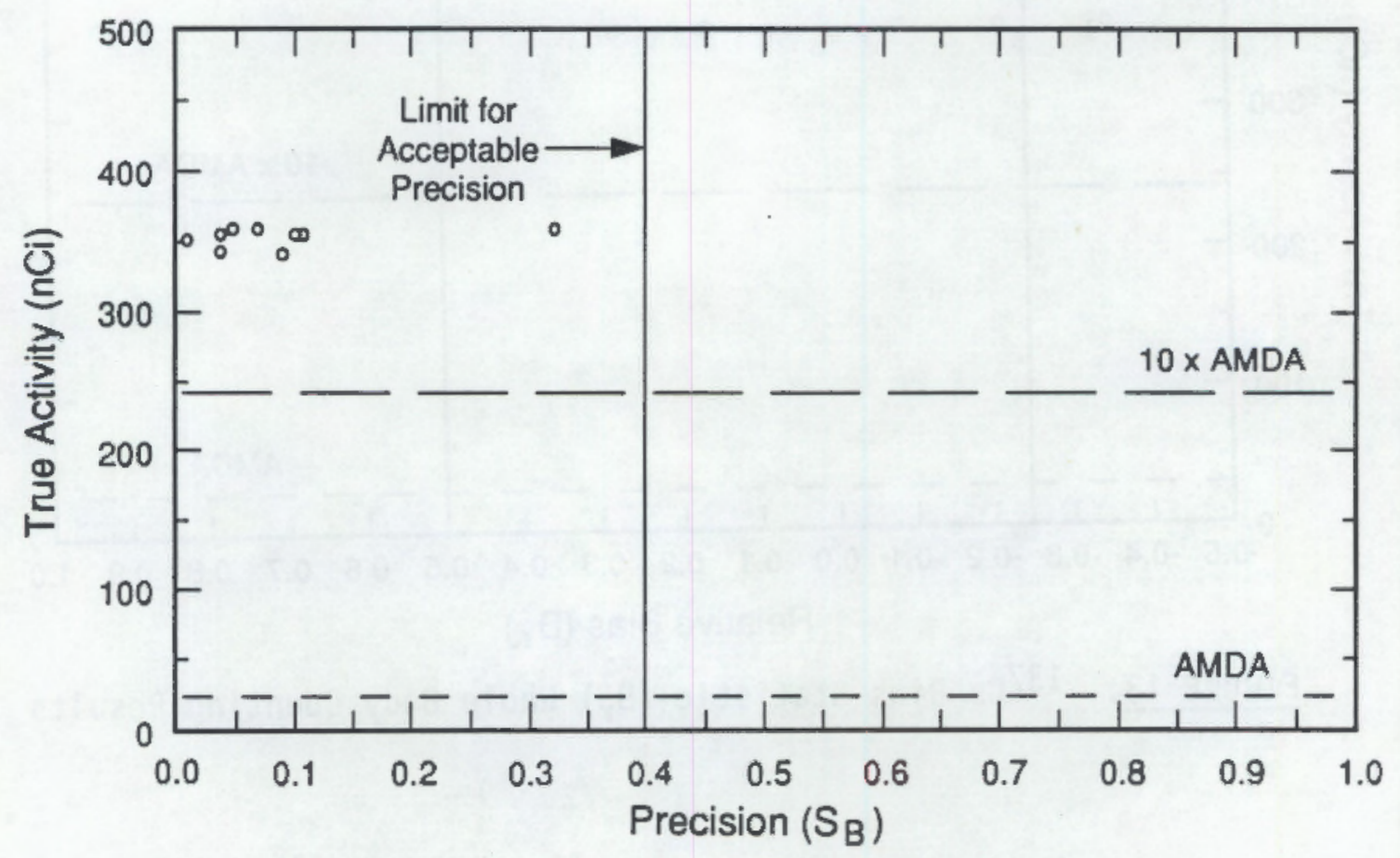

FIGURE $15 .{ }^{137} \mathrm{Cs}$ Precision Statistic $\left(S_{B}\right)$ whole Body Counting Results 
TABLE 15. ${ }^{134}$ Cs Whole Body In Vivo Intercomparison Testing Results (AMDA $=21 \mathrm{nCi}$ )

\begin{tabular}{|c|c|c|c|c|c|c|c|c|c|}
\hline $\begin{array}{c}\text { Laboratory } \\
\text { Code } \\
\end{array}$ & $\frac{\operatorname{lnc}}{\text { Activity }}$ & Assay & $\begin{array}{c}\text { Relative } \\
\text { Bias } \\
\end{array}$ & $\frac{\text { Preci }}{\left(S_{A}\right)}$ & $\frac{\text { fon }}{\left(S_{B}\right)}$ & MDA (nCi) & $\begin{array}{c}\text { Activity } \\
>10 \times \text { AMDA } \\
\end{array}$ & $\begin{array}{c}\text { Systen } \\
\text { Type }\end{array}$ & Pass \\
\hline$A$ & 147.59 & 118.0 & -0.20 & 0.04 & 0.04 & $\operatorname{MC}(a)$ & Ho & (2) MAI & Yes \\
\hline $\begin{array}{l}\text { B1 } \\
\text { B2 }\end{array}$ & $\begin{array}{l}231.99 \\
231.99\end{array}$ & $\begin{array}{l}254.8 \\
143.6\end{array}$ & $\begin{array}{r}0.10 \\
-0.38\end{array}$ & $\begin{array}{l}0.08 \\
0.17\end{array}$ & $\begin{array}{l}0.09 \\
0.11\end{array}$ & $\begin{array}{l}\text { NC } \\
\text { NC }\end{array}$ & $\begin{array}{l}\text { Yes } \\
\text { Yes }\end{array}$ & \multirow{2}{*}{$\begin{array}{l}\mathrm{NAI} / \mathrm{Bed} \\
\text { (3) MAI/ } \\
\text { Chair } \\
\text { MAI/Chair }\end{array}$} & $\begin{array}{l}\text { Yes } \\
\text { No }\end{array}$ \\
\hline G & 197.45 & 143.2 & -0.27 & 0.02 & 0.01 & 4.4 & No & & No \\
\hline I & 238.27 & 248.8 & 0.04 & 0.10 & 0.10 & NC & Yes & MAI/Chair & Yes \\
\hline $\begin{array}{l}\mathrm{J1} \\
\mathrm{J} 2\end{array}$ & 272.81 & 352.5 & 0.29 & 0.26 & 0.34 & $\begin{array}{l}12 \\
20\end{array}$ & Yes & \multirow{2}{*}{$\begin{array}{l}\text { (2)NAI/ } \\
\text { Chair }\end{array}$} & $\begin{array}{l}\text { Yes } \\
\text { No }\end{array}$ \\
\hline$\sqrt{3}$ & 272.81 & 177.7 & -0.35 & 0.18 & 0.11 & 26 & Yes & & No \\
\hline L & 129.38 & 134.0 & 0.04 & 0.09 & 0.09 & 11 & No & \multirow{2}{*}{$\begin{array}{l}\text { CoaxGeLi/ } \\
\text { Chair } \\
\text { MAI/Bed }\end{array}$} & Yes \\
\hline M1 & 228.38 & 209.9 & -0.08 & 0.03 & 0.03 & NC & Yes & & Yes \\
\hline
\end{tabular}

(a) NC = Not calculated due to insufficient data.

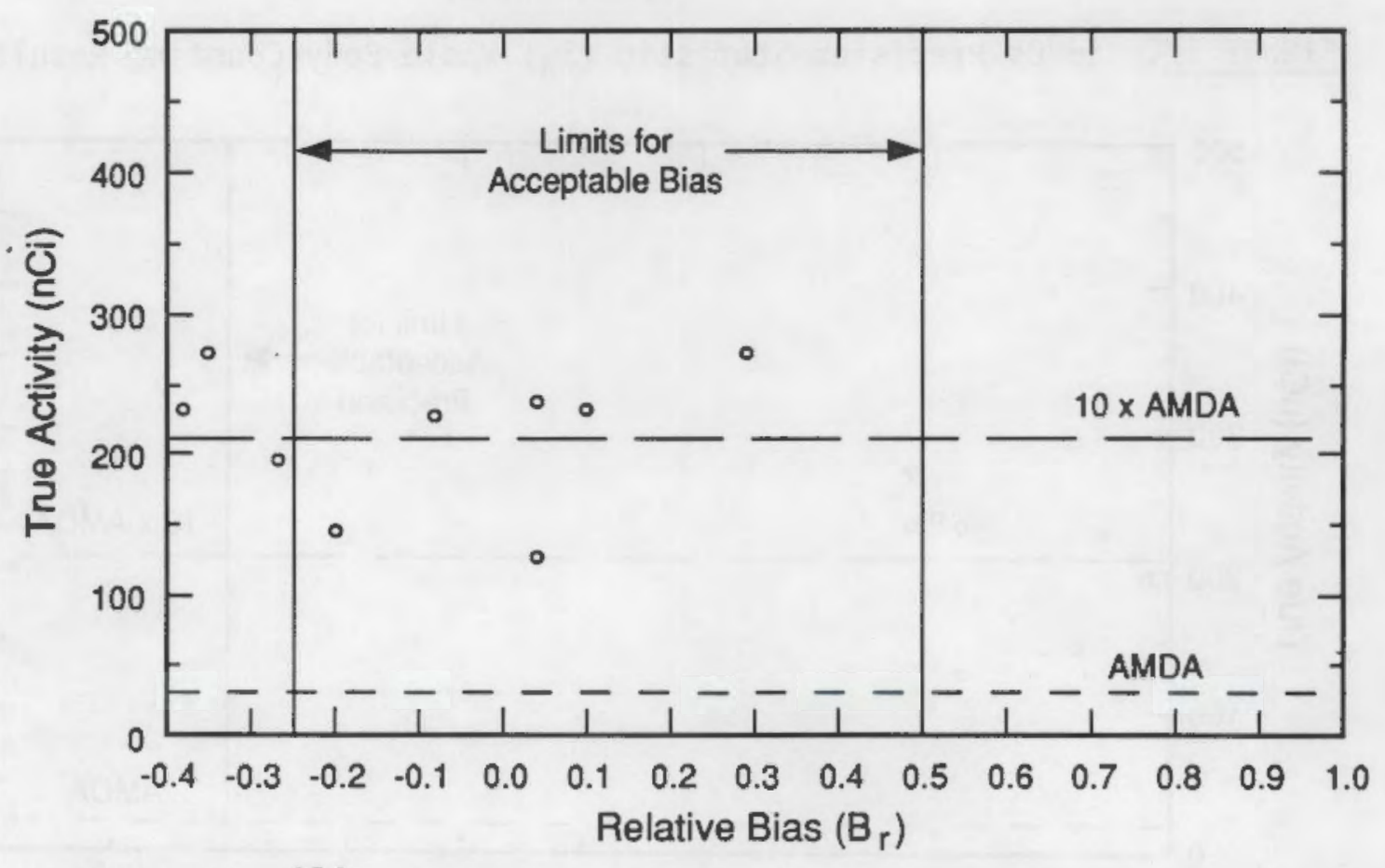

FIGURE $16 .{ }^{134} \mathrm{Cs}$ Bias Statistic $\left(B_{r}\right)$ Whole Body Counting Results 


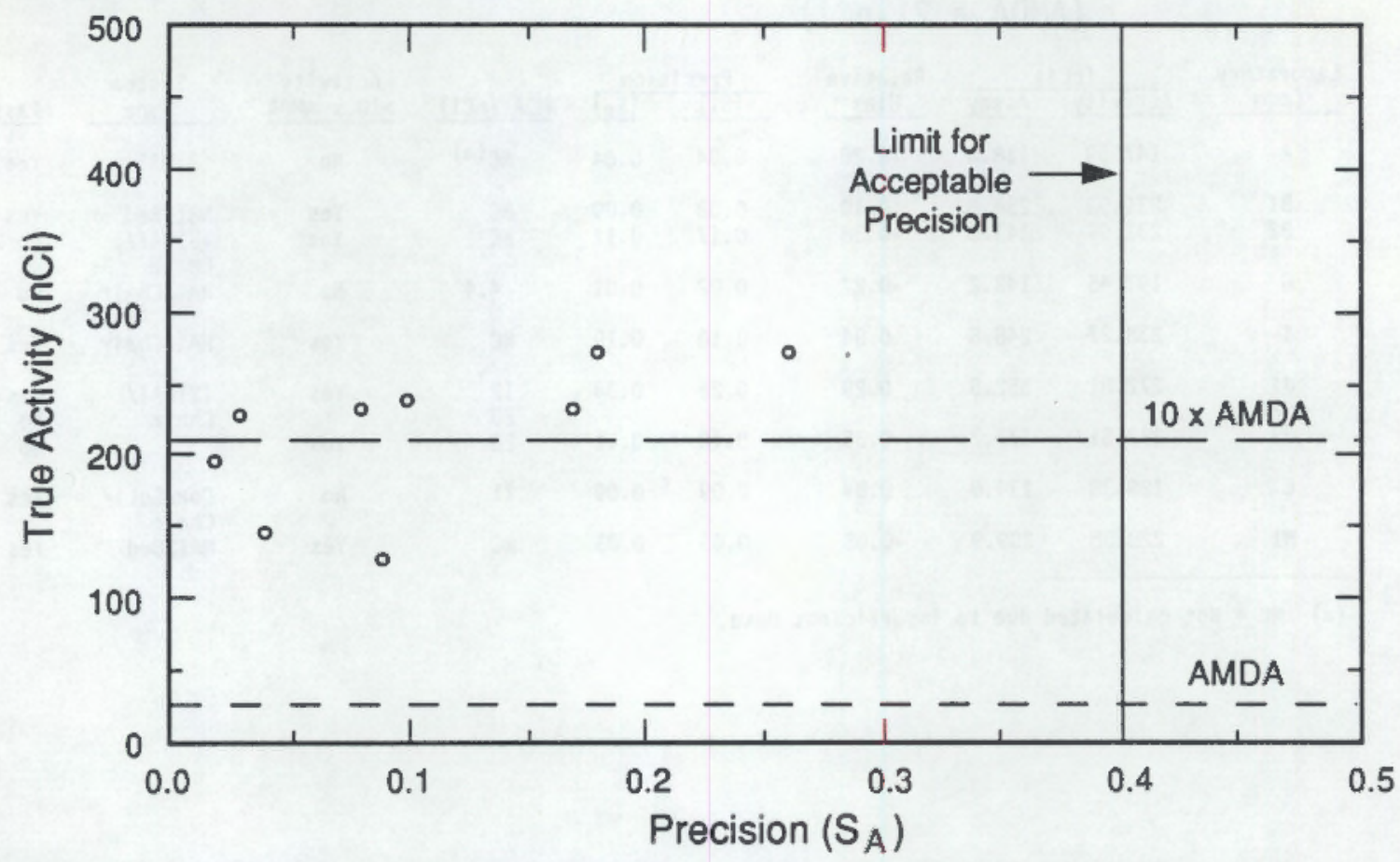

FIGURE $17 .{ }^{134} \mathrm{Cs}$ Precision Statistic $\left(S_{A}\right)$ whole Body Counting Results

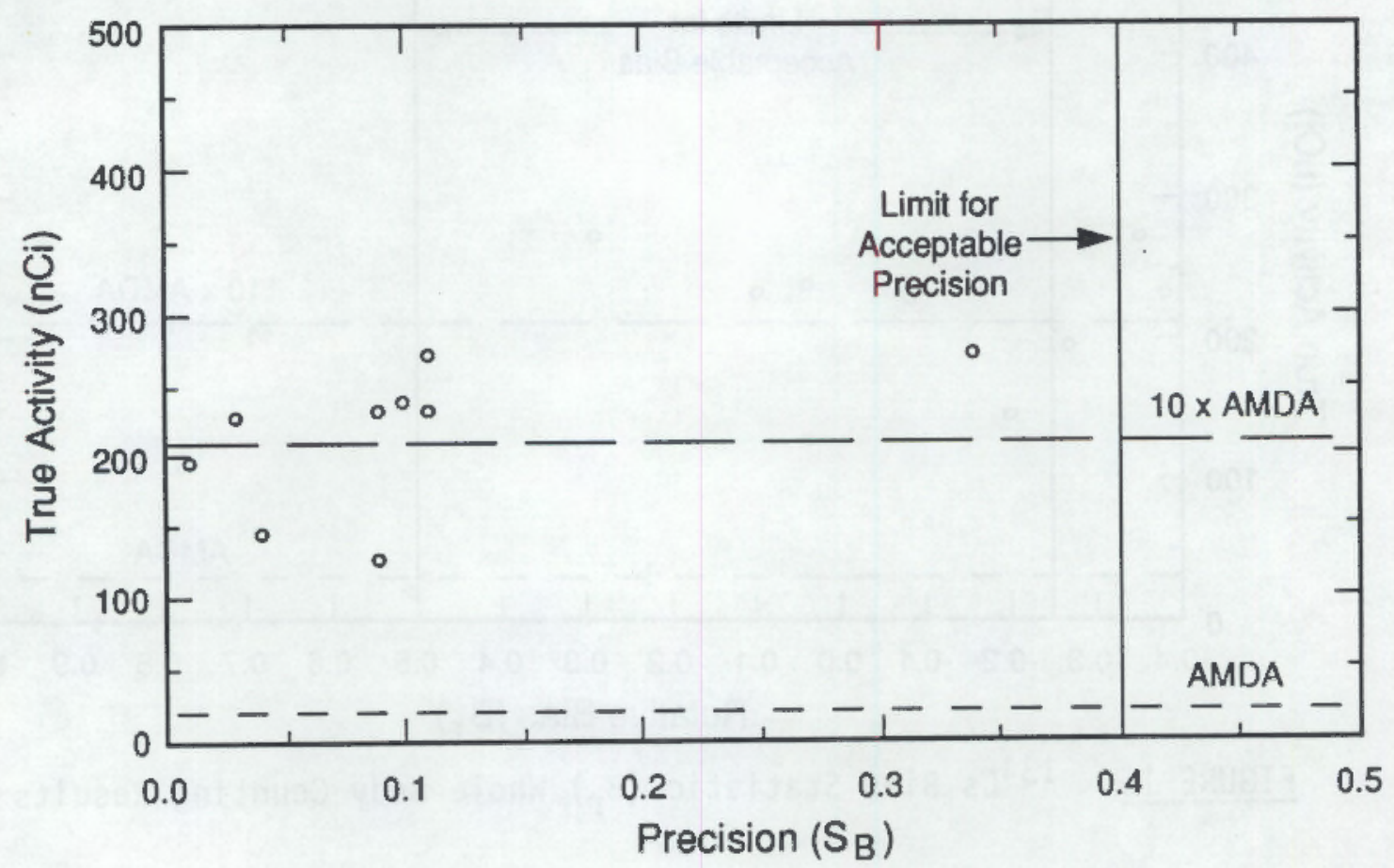

FIGURE $18 .{ }^{134} \mathrm{Cs}$ Precision Statistic $\left(\mathrm{S}_{\mathrm{B}}\right)$ Whole Body Counting Results 
the effective attenuation for the two phantoms is different. The inconsistencies in phantoms was assumed to be the cause of the negative $238 \mathrm{pu}_{\mathrm{u}}$ measurements bias for two laboratories.

The measurement of $238_{\mathrm{U}}$ (by ${ }^{234} \mathrm{Th}$ ) in lungs was successfully passed by all three participating labs for all performance criteria. The MDAs of the facilities were in the range of $30 \%$ to $50 \%$ of the AMDA listed in the current draft ANSI N13.30. As in the previous round of testing, laboratories that need to detect transuranic radionuclides and uranium had analytical facilities, which included custom-built detector systems in shielded vaults. This allowed for substantially lower backgrounds and increased detection capabilities for low-energy, low-level sources. Based on the observed MDAs, the current state-of-the-art detection capability is below the AMDA, thus they are set at an attainable level.

It is not within the scope of this report to determine whether the AMDA is set appropriately with respect to the MDA required to detect a certain effective dose equivalent. The variability of the parameters of intake form, duration of intake, and frequency of bioassay monitoring all combine to make judgment on a single acceptable AMDA value difficult. If a $1.0 \mathrm{nCi} \mathrm{MDA}$ of natural uranium is consistently attainable (as two of the three results determined), then, based on ICRP 30 (1978) methodology, an acute exposure of $15 \%$ of an annual limit on intake (ALI) of class $Y$ natural uranium would be detectable 30 days after intake. This may be satisfactory for some facilities but could potentially cause substantial missed dose in other situations, . especially those with annual or biannual lung counting frequencies.

The lung measurements of ${ }^{54} \mathrm{Mn}$ in the fission product lung sets were less successful. The fission product lung sets included two test radionuclides, ${ }^{54} \mathrm{Mn}$ and ${ }^{144} \mathrm{Ce}$, and two interference nuclides that were not meant to be quantitatively measured, ${ }^{134} \mathrm{Cs}$ and ${ }^{137} \mathrm{Cs}$. For many of the NaI(TI)-based detection systems, the resolution was not sufficient for accurate determinations of the test radionuclides to be made in the presence of the interferences. Several facilities misidentified the nuclide as ${ }^{58} \mathrm{Co}$ and, as mentioned previously, only 5 of 22 facilities returned data on the blank lung set. This meant no MDA could be calculated. However, in the specific case of ${ }^{54} \mathrm{Mn}$, an estimated MDA was calculated for several facilities on the basis of background data returned from the low-level test lung set, because 
the amount of radionuclide in this set of lungs had decayed to the AMDA Ievel. This allowed an estimate of $\left(s_{b}\right)$, the standard deviation of the sample near the MDA, to be made with a fair degree of accuracy. Notably, four of the five facilities passed the MDA criterion by this method. The failure percentage for the bias criteria, the precision statistics, and the MDA values are given in the Round Two section of Table 9.

For the measurement of ${ }^{144} \mathrm{Ce}$, the interference nuclides seemed to reduce the passing rate again. In the case of ${ }^{144} \mathrm{Ce}$, neither lung set at the time of initial shipment had a TQ of radionuclide greater than 10 times the AMDA, so the requirements of draft ANSI N13.30 were not met in testing precision and bias. In spite of this, only one facility failed the precision criterion $S_{B}$, and none failed the $S_{A}$ criterion. However, due to improper quantitative determinations of the interference nuclides large errors were noted in the activity and the bias statistic for ${ }^{144} \mathrm{Ce}$.

The whole body test phantom (BOMAB) results are listed in Tables 14 and 15 for ${ }^{137} \mathrm{Cs}$ and ${ }^{134} \mathrm{Cs}$, respectively. The TQ was above 10 times the AMDA for both radionuclides, but in the case of ${ }^{134} \mathrm{Cs}$ the bias results agajn show a failure rate that resulted from poor quantification or identification of the interference radionuclides ${ }^{54} \mathrm{Mn}$ and ${ }^{60} \mathrm{Co}$.

The passing rate for the bias and precision criteria for the ${ }^{137} \mathrm{Cs}$ whole body category was similar to Round One testing, with the significant exception that many more laboratories did not report background spectral data--55\% for Round Two versus $15 \%$ for Round One. Nevertheless, overall passing of the MDA criterion had increased. Cesium-134 was not included as a whole body test radionuclide in Round One, but the increase in passing both the bias statistic and the precision statistic is dramatic when compared with the other Round One test radionuclide, ${ }^{144} \mathrm{Ce}$. Results for both rounds of in vivo testing are summarized in Table 9 . The test radionuclide, ${ }^{144} \mathrm{Ce}$, was deleted from the whole body category following Round one testing because it was determined to be more appropriately placed in the lung-counting category. When these results are similarly deleted from Round one data, the overall percentage of respondents failing the criteria in Round One and Round Two are similar for both relative bias and relative precision. However, the number of laboratories failing the MDA criterion decreased significantly. 
The decrease in the percentage of laboratories failing the MDA criterion was due to a change in methods used to calculate the MDA. In Round One, the MDA was calculated using a replicate-based estimate of the baseline standard deviation (Robinson et a1. 1986). But, the baseline count in a spectrum is assumed to be a continuum and the baseline under a peak is estimated by the baseline count near the peak. Any between-measurement changes in the baseline will therefore affect the peak baseline and its near-peak estimate equally. The use of a replicate-based estimate of the baseline standard deviation will therefore overestimate the true value of the baseline standard deviation. A Poisson-based estimate of the standard deviation was therefore thought to be more appropriate and Round One estimates are thought to be biased high.

Another complication in the MDA calculation is the critical level $\left(L_{c}\right)$ used by the bioassay laboratory to determine a positive result. For our calculations we have assumed a $5 \%$ level for false identification (i.e., a error). When an automated peak search program scans a spectrum, assuming a $5 \%$ a error for each region of interest results in a large cumulative probability for at least one false identification for each analysis. Many in vivo laboratories compensate for this by decreasing the sensitivity factor of the detection criterion. If a critical level of $3 \sigma_{0}$ is used instead of the assumed $1.645 \sigma_{0}$, the MDA may be increased up to $41 \%$. The participating laboratories were not requested to provide their critical level and the calculated MDA may therefore underestimate the true MDA that a 1aboratory will have when the use of an automated peak search program is wholly depended upon. This may explain why some laboratories failed to detect activity near their calculated MDA. (See Table 13 and Appendix C.)

Some mention must be made of the different participatory status of some of the laboratories that returned results to the testing program. Not all of the equipment that was used to count the various phantoms was in a calibrated and cross-checked operational status. Some members of the study found it useful to attempt calibration of new or unused in vivo counting systems or intercomparisons between instrument systems at the same facility. These results are also listed in the section "Attainability of Performance Criteria." These "experimental" data were many times reported along with data from operational and well-calibrated in vivo counting systems, although they were removed from the calculations upon which conclusions were based. Because 
an objective of these intercomparison studies was to survey the overall capabilities of the industry and DOE in particular, these data were determined to be of value and were included in the resuits. 


\section{CONCLUSIONS AND RECOMMENDATIONS}

The conclusions of this study are based on the type and quality of reported results and the ability of an in vivo testing laboratory to perform measurements within the guidelines specified by the current draft standard. This study attempted to minimize errors that might affect one type of counting system more than another, but, with the variability of in vivo counting systems throughout the United States, some reported results were due to reasons other than inability to repeatedly detect and accurately quantify the test radionuclides.

The increases in performance from Round One to Round Two are somewhat due to the large changes in both the calculation of the performance criteria and the relaxed limits for passing. The appropriateness of the current limits and recomended revisions to draft ANS1 N13.3D are discussed below.

\section{LABORATORY ATTAINMENT OF PERFORMANCE CRITERIA}

The performance criteria of draft ANSI N13.30, as they have been set in the latest version (August 1987), are discussed here in light of the ability of each criterion to be used to identify satisfactory bioassay laboratory performance. The conclusions are based solely on the results reported to PNL and permutations of the data that were undertaken by PNL to test the results.

The bias statistic criterion, which measures a laboratory's overall tendency of deviation from the true known activity of a sample or phantom, is discussed first.

Using the $K$ factor test for tolerance intervals from Report No. 58 of the National Council on Radiation Protection and Measurements (NCRP 1978), the service laboratories results for the relative bias criterion were tested to determine a population passing rate. Using only results from greaterthan-10-AMDA-level test lungs, a population of normally distributed bias results would have a mean of $B_{r}=0.18$ with a standard deviation of \pm 0.45 . Based on the current boundaries of the relative bias statistic of -0.25 to +0.5 , approximately $60 \%$ of service laboratories would be expected to pass.

The assumption of normality may not be appropriate here due to factors in some laboratories' bias results from interferences and calculational errors. 
Because several laboratories misidentified nuclides, this tolerance level statistic is not appropriate in determining whether the bias criterion is set at an appropriate or attainable level.

However, when outlying data are removed that were due to 1) misidentification of nuclide, 2) miscalculations of either activity or interference, or 3) uncalibrated counting systems, the change in overall performance is dramatic. The mean bias of all laboratory results is now 0.084 with a standard deviation of \pm 0.308 . Thus, the current bias range of -0.25 to +0.50 would include approximately $80 \%$ of a population of laboratory results.

It can therefore be said that the bias statistic is set at a satisfactory level and that failures are due to gross forms of error that can be corrected for by training and upgrading laboratory $Q C$ ability.

The relative precision criteria were surpassed in only three results from the population of laboratories tested in Round Two. The use of a one-sided $t$-factor table results in more than $95 \%$ of a population of tested facilities being expected to pass the current criteria of relative precision, $\left(S_{B}\right)$ or $\left(S_{A}\right)$, assuming a nomal distribution with a mean of 0.102 and a standard deviation of 0.128 . By itself, it can be concluded that the relative precision statistic is set at an attainable level.

AIthough the performance criteria could be lowered without significantly increasing the number of failures, the cumulative probability of passing all criteria must be considered. The apparent looseness of the criteria is discussed in Appendix $C$ of draft ANSI N13.30. The criteria were set so that a good laboratory could expect to pass all three criteria with a reasonably high probability. If the criteria are independent, the probability of passing all three is the product of the probabilities of passing each criterion. If a laboratory had a $95 \%$ probability of passing each criterion, its overall probability of passing a test category would be $(0.95) \cdot(0.95) \cdot(0.95)$ or 0.86 . Therefore, the laboratory would need better than a $98 \%$ probability of passing each category in order to have an overall 95\% probability of passing a complete test category. Considering the cumulative effect of multiple test criteria, none of the criteria is overly restrictive. 
The MDA criterion was the most prevalent cause of failure for participating laboratories. There are four possible causes for the large number of laboratories failing the MDA criterion:

- The measurement systems for these laboratories were truly incapable of detecting radioactivity at the level specified in draft ANSI N13.30.

- The MDA was calculated using an improper estimate of the standard deviation of the net blank count.

- The evaluation of the calculated MDA failed to consider the uncertainty in the MDA estimate.

- The analysis laboratory's automated counting system did not have the capability of giving blank or background counting information, and none was submitted to the testing laboratory (PNL).

The first three of these causes are discussed in detail by MacLellan (1989).

Analysis procedures that are incapable of detecting radioactivity at the required level should fail the performance test, but the second and third causes of failure are related to the procedures used by the testing laboratory to evaluate the performance test data. The final reason, by far the most frequent reason for failure in this study, should be noted for future efforts in developing computer software for automated counting systems. The inability of many systems to allow for the removal of raw counting data or manual options that can quantify regions of interest of multi-channel spectra will severely inhibit any standardization of laboratories. The current trend of only allowing identification of spectral peaks above certain confidence intervals and not allowing user-set regions of interest to be quantified for background and blank spectrai data will inhibit the ability of a testing laboratory to adequately perform accreditation testing. The use of a facility's QC data, which may include calculated MDAs generated by software packages, should be treated with caution. The necessary confidence must first be obtained in both the software analys is system that the laboratory has chosen and the proper input of information by the user of the software. Any analysis software packages used in an accredited program should have mandatory manual capabilities, and all algorithms used in calculational steps should be documented precisely. 


\section{RECOMMENDED REVISIONS TO DRAFT ANSI N13.30}

The MDA criteria were based on previously published criteria from other standards and advisory groups and the capabilities of bioassay laboratories reported in their procedures manuals. Primary sources were the derived investigation levels from publications such as Publication 10 of the International Cammission of Radiological Protection (ICRP 1960). In the future, regulations will be based on dose calculations done with ICRP 30 (1978) methodology.

The AMOA values were established with the sometimes conflicting objectives of: 1) adequate worker protection from radionuclides, 2) reasonable levels attainable without expending unnecessary resources, and 3) state-ofthe-art detection limits; thus, it is often difficult to detemine where an AMDA should be set. Current AMDA values are in some cases too high to enable detection of internal radioactivity at desired levels. In these cases, new AMDA levels should be set each time it becomes obvious that the state of the art allows for further reductions and worker protection requires further reductions.

The current settings of the tested AMDAs (for Round Two) were attainable by most of the tested service laboratories, and in some instances $10 \%$ of the AMDA was the norm. Other service laboratories with poorly calibrated and inexpensive detection systems failed bias and precision criteria, but still passed the AMOA.

Attempting to relate AMDA performance of Round One to Round Two is clouded by the use of an entirely different set radionuclides. If comparison is made of similar radionuclides in the same nuclide category, then it is obvious that advances were made. Overall only $9 \%$ of service laboratories failed the AMDA criteria, compared with $38 \%$ in Round One.

The calculations of MOA used in draft ANSI N13.30 should take into account the potential errors involved in a facility's analysis system and apply confidence intervals to the calculated MOA. The most accurate method of determining this criteria would be from a laboratory's own QC data.

The statistics for simple counting systems are reasonably well defined, but some comercial in vivo counting systems do not allow for inspection of the raw spectral data and often report only "less than" values when they are 
less than the MOA calculated by the software. It is impossible to verify compliance of these systems with the draft standard MDA criterion.

It is often necessary to examine the QC data to identify important characteristics of the blank distribution that will affect the MOA calculation (Maclellan 1989). Characteristics such as unequal variances of detectors, unstable electronics, and paired samples must all be considered. The MDA equation must be based on the analysis and calculational methods of the procedure evaluated. No single MOA equation will be appropriate for all analyses.

Even when the correct MDA equation is applied, the MDA calculated may have a relatively large confidence interval when relatively few replicates are used to estimate the standard deviation. At least 13 replicates are needed to limit the ratio of the upper-to-lower bound of the $90 \%$ confidence interval to 2 (Currie 1984). For this reason, a relatively precise estimate of the MDA is generally only available when Poisson statistics may be applied.

With the above performance test limitations in mind, the following recomendations are made for determination of the MOA in conjunction with draft ANSI N13.30 performance testing:

- The bioassay laboratory's own QC data should be used for the MDA calculation in preference to the small data set available from performance testing.

- The MDA equation should be designed specificaliy for the measurement process being evaluated. If generic MDA equations are developed, the assumptions used should be verified whenever one is applied.

- Poisson statistics should be assumed for the MDA calculation whenever the Poisson distribution is not rejected for the available data.

- If Poisson statistics are rejected, the standard deviation should be estimated from replicates and a confidence interval should be calculated for the MDA. The laboratory should not be failed if the lower 5\% bound of the confidence interval is less than the MOA criterion of draft ANSI N13.30. This approach is recommended because of the inherent uncertainty of the replicate-based MDA estimate.

The premise common to all the above recommendations is that performance testing alone cannot provide all of the information necessary to make an accurate estimate of the measurement process MDA. Review of the laboratory's QC data and the entire measurement procedure will be necessary. 


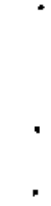




\section{REFERENCES}

American National Standards Institute (ANSI). 1989. Performance Criteria for Radiobioassay. Draft ANSI N13.30, New York, New York.

Brodsky, A. 1986. Accuracy and Detection Limits on Radiation Protection-Statistical Considerations. NUREG-1156, Office of Nuclear Regulatory Research, U.S. Nuclear Regulatory Commission, Washington, D.C.

Currie, L. A. 1984. Lower Limit of Detection: Definition and Elaboration of a Proposed Position for Radiological Effluent and Environmental Measurements. NUREG/CR-4007, National Bureau of Standards, Washington, D.C.

Fenrick, H. W., and J. A. MacLellan. 1988a. Recommended Procedures for Performance Testing of Radiobioassay Laboratories: Volume 1: Quality Assurance. PNL-6067 Vol.1, Pacific Northwest Laboratory, Richland, Washington.

Fenrick, H. W., and J. A. MacLellan. 1988b. Recommended Procedures for Performance Testing of Radiobioassay Laboratories: Volume 2: In Vitro Samples. PNL-6067 Vol.2, Pacific Northwest Laboratory, Richland, Washington.

International Commission on Radiological Protection (ICRP). 1978. Limits for Intakes of Radionuclides by Workers. ICRP 30, Pergamon Press, Fairview Park, Elmsford, New York.

International Comission on Radiological Protection (ICRP). 1960. Report by Cominittee 4 - Evaluation of Radiation Doses to Body Tissues from Internal Contamination Due to Occupational Exposure. ICRP 10, Permagon Press, Fairview Park, Elinsford, New York.

MacLellan, J. A. 1988. Performance Testing of Radiobioassay Laboratories: In Vitro Measurements, Fecal Study Report. PNL-6601, Pacific Northwest Laboratory, Richland, Washington.

MacLellan, J. A. 1989. Causes of Failing the Draft ANSI Standard N13.30, "Performance Criteria for Bioassay, "Criteria for the Minimum Detectable Amount. NUREG/CR-5516, U.S. Nuclear Regulatory Comission, Washington, D.C.

MacLellan, J, A., and R. J. Traub. 1988. Recommended Procedures for Performance Testing of Radiobioassay Laboratories: Volume 3 In Vivo Samples. PNL-6067, Pacific Northwest Laboratory, Richland, Washington.

Maclellan, J. A., R. J. Traub, and D. R. Fisher. 1988. Performance Testing of Radiobioassay Laboratories: In Vitro Measurements (Urinalysis), Final Report. PNL-6490, Pacific Northwest Laboratory, Richland, Washington.

National Council on Radiation Protection and Measurements (NCRP). 1978. A Handbook of Radioactivity Measurement Procedures. Report No. 58, Washington, D.C. 
Remington, R. D., and M. A. Schork. 1970. Statistics with Applications for the Biological and Health Sciences. Prentice-Hall, Inc., Englewood Cliffs, New Jersey.

Robinson, A. V., D. R. Fisher, and R. T. Hadley, 1984. Performance Testing of Radiobioassay Laboratories: In-Vitro Measurements, Pilot Study Report. NUREG/CR-3809, DOE/NBM 1071, PNL-5348, Vol, 1, Pacific Northwest Laboratory, Richland, Washington.

Robinson, A. V., D. R. Fisher, W. D. Reece, and J. A. MacLellan. 1986. Performance Testing of Radiobioassay Laboratories: In-Vivo Measurements, Pjlot Study Report. PKL-5840, Pacific Northwest Laboratory, Richland, Washington.

Scherpe12, R. I., and J. A. MacLellan. 1987. Comparison of Uniform and Discrete Source Distributions for Use in Bioassay Laboratory Performance Testing. PNL-6303, Pacific Northwest Laboratory, Richland, Washington.

Traub, R. J., and A. V. Robinson. 1987. "The Sources of Uncertainties Associated with Internal Dose Calculations." In: Proceedings of the Department of Energy Workshop on Radiobioassay and Internal Dosimetry, PNL-SA-14043, Pacific Northwest Laboratory, Richland, Washington.

49 CFR 173. 1985. U.S. Department of Transportation, "Shipper-General Requirements for Shipments and Packagings." Section 173.421, U.S. Code of Federal Regulations. 
APPENDIX A

IN VIVO MEASUREMENTS REPORT FORM 
Laboratory Name:

Phantom Type: Lung Whole Body

Address:

Contact Person:

Nuclide (s):

Date of Phantom Receipt:

Phone:

Brief description of counting equipment (shielding. detection. geometry):

Type of appropriate blank used for the Analysis:

\begin{tabular}{|c|c|c|c|c|}
\hline $\begin{array}{l}\text { Count a Total }(b) \\
\text { No. Counts }\end{array}$ & $\begin{array}{l}\text { Counting } \\
\text { Time (min) }\end{array}$ & $\begin{array}{l}\text { Background }(c) \\
\text { Count Rate }\end{array}$ & $\begin{array}{l}\text { Counting(d) } \\
\text { Efficiency }\end{array}$ & $\begin{array}{l}\text { Assay }(e) \\
\text { (nCi) }\end{array}$ \\
\hline
\end{tabular}

1

2

3

4

5

(a) Remove and reposition phantom after each count.

(b) Region of interest, total counts.

(c) Region of interest, count rate.

(d) Count rate per unit activity in the phantom $(\mathrm{cpm} / \mathrm{nCi})$.

(e) Report calculated assay, including negative values and values < MDA.

Estimated Minimum Detectable Activity (MDA); nCi

Please return this form to: Jay MacLellan

Pacific Northwest Laboratory

P.0. Box 999

Richland, Washington 99352

(509) $375-2626$ 


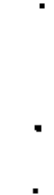




\section{APPENDIX B}

PROPAGATION OF ERROR IN SPIKED IN VIVO PHANTOMS 


\section{APPENDIX B}

\section{PROPAGATION OF ERROR IN SPIKED IN VIVO PHANTOMS}

The sources of error in the preparation of the whole body and lung phantoms used in this study are documented Table B.1 below. These include a quantification of the potential measurement errors in the various gravimetric and volumetric procedures that were followed to develop the spiked phantoms.

Al1 the errors in the development of lung phantoms are common to every phantom with the exception of the calibration uncertainty of each radionuclide standard incorporated into the lungs. This source of error has aiso been included in the overall errors listed in Tables 5 and 6 in the text.

The standard deviations used in Table 5 and 6 assume linear propagation of errors in the various that are traceable to NIST standards and the above volumetric and gravimetric errors. A11 propagated error was less than a maximum of $3.5 \%$.

TABLE B.1. Errors Associated with Phantom Preparation

\begin{tabular}{|c|c|c|}
\hline Errors & $\begin{array}{l}\text { Whole Body } \\
\text { Phantom }\end{array}$ & $\begin{array}{c}\text { Lung } \\
\text { Phantom } \\
\end{array}$ \\
\hline Weighing & $=0.15 \%$ & $=0.5 \%$ \\
\hline Volumetric & $\pm 0.20 \%$ & NA \\
\hline Stock solution preparation & $\pm 1 \frac{q}{6}$ & $=1 \%$ \\
\hline Radionuclide calibration & $\pm 0.5-2 \%$ & $+0.5-2 \%$ \\
\hline
\end{tabular}




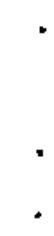


APPENDIX C

IN VIVO BIOASSAY COUNTING RESULTS 
IN VIVO BIOASSAY COUNTING RESULTS

TABLE C.1. In Vivo Bioassay Counting Results

\begin{tabular}{|c|c|c|c|c|c|c|}
\hline $\begin{array}{l}\text { LAB } \\
\text { CODE } \\
A \\
A \\
A \\
A \\
A \\
A\end{array}$ & $\begin{array}{l}\text { PHANTO1M } \\
\text { TYPE (a) } \\
W 1-C S 134 \\
W 1-C S 134 \\
W 1-C S 134 \\
W 1-C S 134 \\
W 1-C S 134 \\
W 1-C S 134\end{array}$ & $\begin{array}{c}\text { COUNT } \\
\text { NO. } \\
1 \\
2 \\
3 \\
4 \\
5 \\
6\end{array}$ & $\begin{array}{c}\text { DATE } \\
\text { COUNTED } \\
8-20=88 \\
8=20=88 \\
8=20=88 \\
8=20=88 \\
8=20=88 \\
8-20=88\end{array}$ & $\begin{array}{c}\text { LAB ASSAY } \\
\text { (nCi) } \\
120.00 \\
119.00 \\
123.00 \\
120.00 \\
108.00 \\
118.00\end{array}$ & $\begin{array}{l}\text { ERROR( }(8) \text { (b) } \\
4.00 \\
4.00 \\
4.00 \\
4.00 \\
4.00 \\
4.00\end{array}$ & $\begin{array}{c}\text { TRUE } \\
\text { SPIKE } \\
147.59 \\
147.59 \\
147.59 \\
147.59 \\
147.59 \\
147.59\end{array}$ \\
\hline
\end{tabular}

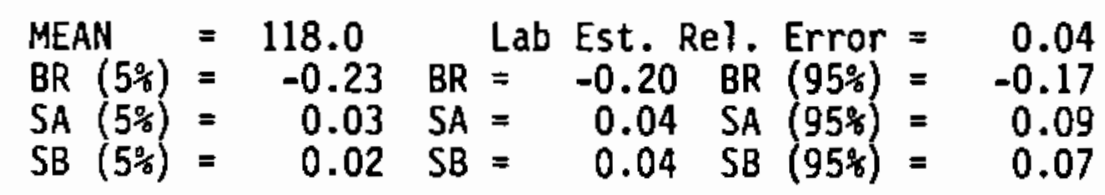

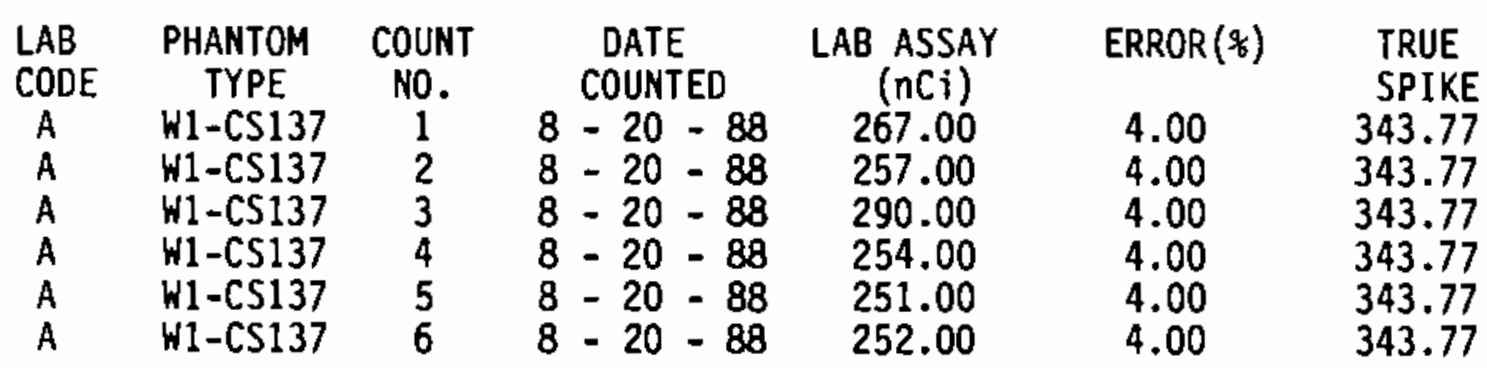

MEAN $=261.8 \quad$ Lab Est. Rel. Error $=0.04$
BR (5\%) $=-0.27$ BR $=-0.24$ BR $(95 \%)=-0.20$
SA (5\%) $=0.04$ SA $=0.06$ SA $(95 \%)=0.12$
SB (5\%) $=0.03$ SB $=0.04$ SB $(95 \%)=0.09$

\begin{tabular}{|c|c|c|c|c|c|}
\hline $\begin{array}{l}\text { LAB } \\
\text { CODE } \\
A \\
A \\
A\end{array}$ & $\begin{array}{l}\text { PHANTOM } \\
\text { TYPE } \\
\text { M2-MN54 } \\
\text { M2-MN54 } \\
\text { M2-MN54 }\end{array}$ & $\begin{array}{c}\text { COUNT } \\
\text { NO. } \\
1 \\
2 \\
3\end{array}$ & \begin{tabular}{c} 
DATE \\
\multicolumn{1}{c}{ COUNTED } \\
$9-24-88$ \\
$9-24-88$ \\
$9-24-88$
\end{tabular} & $\begin{array}{c}\text { LAB ASSAY } \\
\text { (nCi) } \\
6.20 \\
6.90 \\
7.80\end{array}$ & $\begin{array}{c}\text { ERROR(\%) } \\
1.00 \\
1.00 \\
1.00\end{array}$ \\
\hline
\end{tabular}

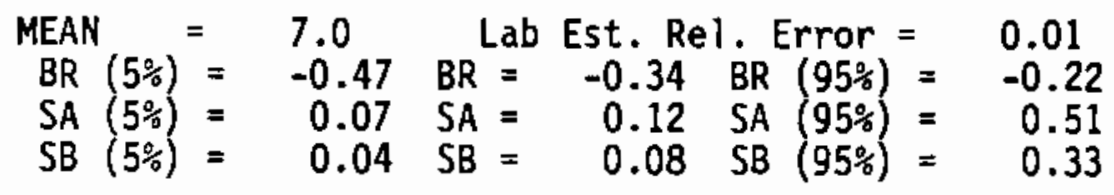

(a) Phantom type: $W=$ Whole body $M=$ lung/mixed fission product, $u=$ lung/uranium, $P=$ lung/ $238 \mathrm{Pu}, 1-3=$ coded activity level's.

(b) \% error reported by laboratory as estimated error on reporting form. 


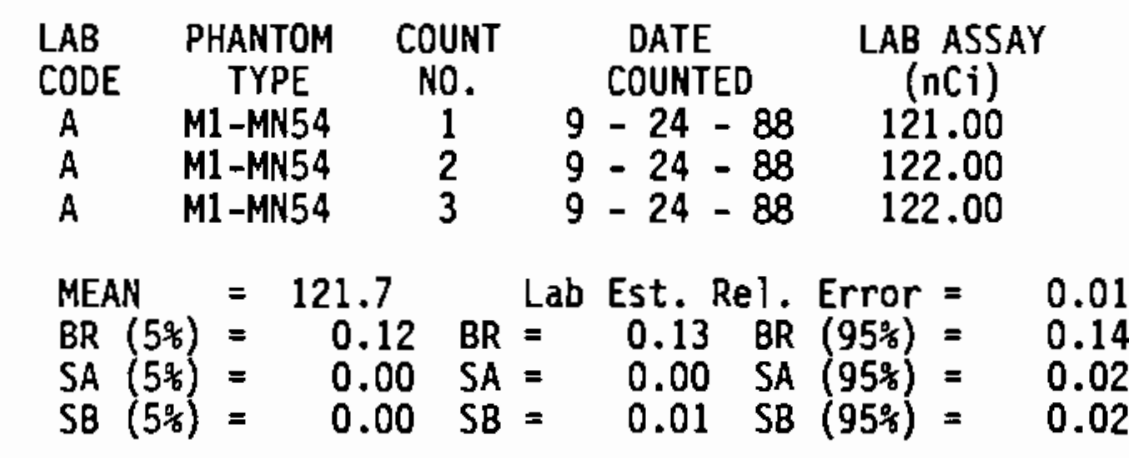

$\begin{array}{ccccccc}\text { LAB } & \text { PHANTOM } & \text { COUNT } & \text { DATE } & \text { LAB ASSAY } & \text { ERROR(\%) } & \text { TRUE } \\ \text { CODE } & \text { TYPE } & \text { NO. } & \text { COUNTED } & \text { (nCi) } & & \text { SPIKE } \\ \text { A } & \text { M2-CE144 } & 1 & 9-24-88 & 95.00 & 30.00 & 30.25 \\ \text { A } & \text { M2-CE144 } & 2 & 9-24-88 & 94.00 & 29.00 & 30.25 \\ \text { A } & \text { M2-CE144 } & 3 & 9-24-88 & 94.00 & 29.00 & 30.25\end{array}$

\begin{tabular}{|c|c|c|c|c|c|c|c|c|}
\hline $\begin{array}{l}\text { MEAN } \\
\text { BR } \quad(5 \%) \\
\text { SA } \quad(5 \%) \\
\text { SB } \quad(5 \%)\end{array}$ & $\begin{array}{l}= \\
= \\
= \\
=\end{array}$ & $\begin{array}{c}94.3 \\
2.09 \\
0.00 \\
0.01\end{array}$ & $\begin{array}{l}\text { BR } \\
\text { SA } \\
\text { SB }\end{array}$ & $\begin{array}{l}\text { Lab } \\
= \\
= \\
=\end{array}$ & $\begin{array}{l}\text { Est. } \\
2.12 \\
0.01 \\
0.02\end{array}$ & $\begin{array}{l}\text { Rel } \\
\text { BR } \\
\text { SA } \\
\text { SB }\end{array}$ & $\begin{array}{l}\text { Error } \\
(95 \%) \\
(95 \%) \\
(95 \%)\end{array}$ & \\
\hline
\end{tabular}

$\begin{array}{lcccccr}\text { LAB } & \text { PHANTOM } & \text { COUNT } & \text { DATE } & \text { LAB ASSAY } & \text { ERROR(\%) } & \text { TRUE } \\ \text { CODE } & \text { TYPE } & \text { NO. } & \text { COUNTED } & \text { (nCi) } & & \text { SPIKE } \\ \text { A } & \text { M1-CE144 } & 1 & 9-24-88 & 385.00 & 13.00 & 260.92 \\ \text { A } & \text { M1-CE144 } & 2 & 9-24-88 & 395.00 & 11.00 & 260.92 \\ \text { A } & \text { M1-CE144 } & 3 & 9-24-88 & 385.00 & 11.00 & 260.92\end{array}$

\begin{tabular}{|c|c|c|c|c|c|c|c|c|}
\hline $\begin{array}{l}\text { MEAN } \\
\text { BR }(5 \%) \\
\text { SA (5\%) } \\
\text { SB (5\%) }\end{array}$ & $\begin{array}{l}= \\
= \\
= \\
=\end{array}$ & $\begin{array}{r}388.3 \\
0.45 \\
0.01 \\
0.01\end{array}$ & $\begin{array}{l}\text { BR } \\
\text { SA } \\
\text { SB }\end{array}$ & $\begin{array}{l}\text { Lab } \\
= \\
= \\
=\end{array}$ & $\begin{array}{c}\text { Est. } \\
0.49 \\
0.01 \\
0.02\end{array}$ & $\begin{array}{l}\text { Rel. } \\
\text { BR } \\
\text { SA } \\
\text { SB }\end{array}$ & $\begin{array}{l}\text { Error } \\
(95 \%) \\
(95 \%) \\
(95 \%)\end{array}$ & \\
\hline
\end{tabular}

$\begin{array}{ccccccr}\text { LAB } & \text { PHANTOM } & \text { COUNT } & \text { DATE } & \text { LAB ASSAY } & \text { ERROR(q) } & \text { TRUE } \\ \text { CODE } & \text { TYPE } & \text { NO. } & \text { COUNTED } & \text { (nCi) } & & \text { SPIKE } \\ \text { A } & \text { U3-U238 } & 1 & 10-1-88 & 5.10 & 1.00 & 3.51 \\ \text { A } & \text { U3-U238 } & 2 & 10-1-88 & 4.90 & 1.00 & 3.51\end{array}$

$\begin{array}{llllll}\text { MEAN } & =5.0 & \text { Lab Est. Re1. Error }= & 0.01 \\ \text { BR }(5 \%)= & 0.24 & \text { BR }= & 0.42 & \text { BR }(95 \%)= & 0.60 \\ \text { SA }(5 \%)= & 0.01 & \text { SA }= & 0.03 & \text { SA }(95 \%)= & 0.45 \\ \text { SB }(5 \%) & =0.02 & \text { SB }= & 0.04 & \text { SB }(95 \%)= & 0.64\end{array}$




$\begin{array}{ccccccc}\text { LAB } & \text { PHANTOM } & \text { COUNT } & \text { DATE } & \text { LAB ASSAY } & \text { ERROR }(\%) & \text { TRUE } \\ \text { COOE } & \text { TYPE } & \text { NO. } & \text { COUNTEO } & (n C i) & & \text { SPIKE } \\ \text { A } & \text { U1-U238 } & 1 & 10-1-88 & 33.00 & 1.00 & 33.07 \\ \text { A } & \text { U1-U238 } & 2 & 10-1-88 & 34.00 & 1.00 & 33.07 \\ \text { A } & \text { U1-U238 } & 3 & 10-1-88 & 34.00 & 1.00 & 33.07\end{array}$

\begin{tabular}{|c|c|c|c|c|c|c|c|c|c|}
\hline $\begin{array}{l}\text { MEAN } \\
\text { BR } \quad(5 \%) \\
\text { SA }(5 \%) \\
\text { SB }(5 \%)\end{array}$ & $\begin{array}{l}= \\
=\end{array}$ & $\begin{array}{l}33.7 \\
-0.01 \\
0.01 \\
0.01\end{array}$ & $\begin{array}{l}B R \\
S A \\
S B\end{array}$ & $\begin{array}{l}\text { Lab } \\
= \\
= \\
=\end{array}$ & $\begin{array}{c}\text { Est. } \\
0.02 \\
0.02 \\
0.02\end{array}$ & $\begin{array}{l}\text { Rel } \\
\text { BR } \\
\text { SA } \\
\text { SB }\end{array}$ & $\begin{array}{l}\text { Error } \\
(95 \%) \\
(95 \%) \\
(95 \%)\end{array}$ & & $\begin{array}{l}0.01 \\
0.05 \\
0.08 \\
0.08\end{array}$ \\
\hline
\end{tabular}

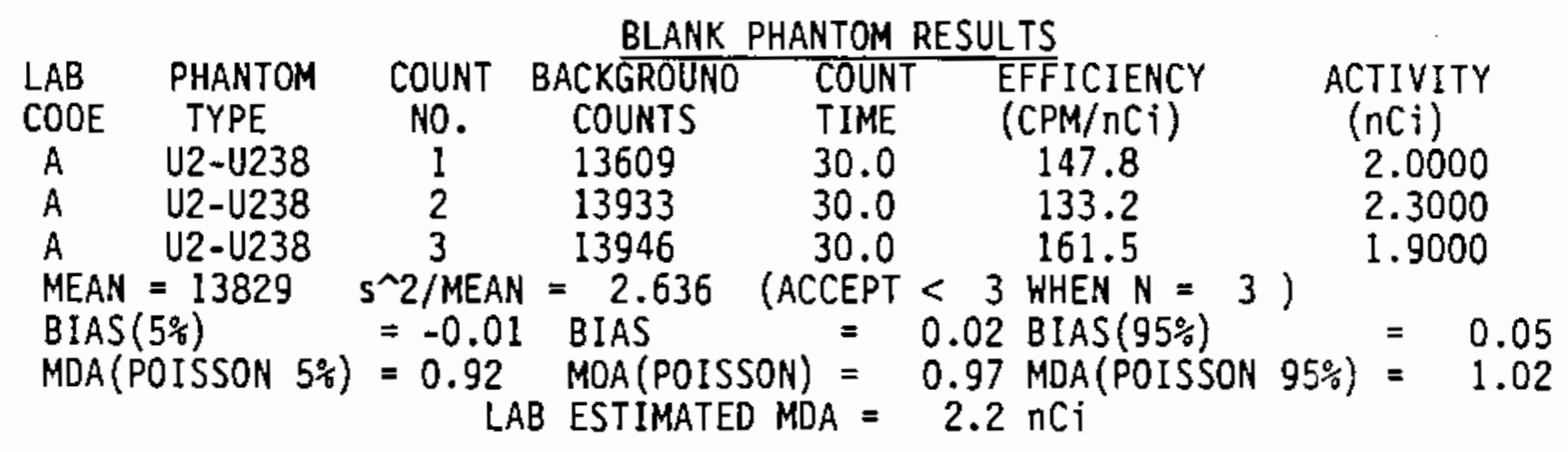

$\begin{array}{ccccccc}\text { LAB } & \text { PHANTOM } & \text { COUNT } & \text { DATE } & \text { LAB ASSAY } & \text { ERROR(\%) } & \text { TRUE } \\ \text { COOE } & \text { TYPE } & \text { NO. } & \text { COUNTEO } & \text { (nCi) } & & \text { SPIKE } \\ \text { A } & \text { P2-PU238 } & 1 & 9-30-88 & 24.00 & 1.00 & 31.94 \\ \text { A } & \text { P2-PU238 } & 2 & 9-30-88 & 25.00 & 1.00 & 31.94 \\ \text { A } & \text { P2-PU238 } & 3 & 9-30-88 & 22.00 & 1.00 & 31.94 \\ \text { A } & \text { P2-PU238 } & 4 & 9-30-88 & 21.00 & 1.00 & 31.94\end{array}$

$\begin{array}{llll}\text { MEAN }= & 23.0 & \text { Lab Est. Rel. Error }= & 0.01 \\ \text { BR }(5 \%)= & -0.35 \text { BR }= & -0.28 \text { BR }(95 \%)= & -0.21 \\ \text { SA }(5 \%)= & 0.05 \text { SA }= & 0.08 \text { SA }(95 \%)= & 0.23 \\ \text { SB }(5 \%)= & 0.04 \text { SB }=0.06 \mathrm{SB}(95 \%)= & 0.17\end{array}$

\begin{tabular}{|c|c|c|c|c|c|c|}
\hline $\begin{array}{l}\text { LAB } \\
\text { CODE } \\
A \\
A \\
A \\
A\end{array}$ & $\begin{array}{l}\text { PHANTOM } \\
\text { TYPE } \\
\text { P3-PU238 } \\
\text { P3-PU238 } \\
\text { P3-PU238 } \\
\text { P3-PU238 }\end{array}$ & $\begin{array}{c}\text { COUNT } \\
\text { NO. } \\
1 \\
2 \\
3 \\
4\end{array}$ & $\begin{array}{c}\text { DATE } \\
\text { COUNTED } \\
9-30=88 \\
9-30=88 \\
9-30=88 \\
9-30-88\end{array}$ & $\begin{array}{c}\text { LAB ASSAY } \\
(\mathrm{nCi}) \\
245.00 \\
245.00 \\
250.00 \\
241.00\end{array}$ & $\begin{array}{l}1.00 \\
1.00 \\
1.00 \\
1.00\end{array}$ & $\begin{array}{c}\text { TRUE } \\
\text { SPIKE } \\
367.66 \\
367.66 \\
367.66 \\
367.66\end{array}$ \\
\hline
\end{tabular}

MEAN $=245.3 \quad$ Lab Est. Rel. Error $=0.01$

$B R(5 \%)=-0.34$ BR $=-0.33$ BR $(95 \%)=-0.32$

$\mathrm{SA}(5 \%)=0.01 \mathrm{SA}=0.02 \mathrm{SA}(95 \%)=0.04$

$\mathrm{SB}(5 \%)=0.01 \mathrm{SB}=0.01 \mathrm{SB}(95 \%)=0.03$ 
BLANK PHANTOM RESULTS

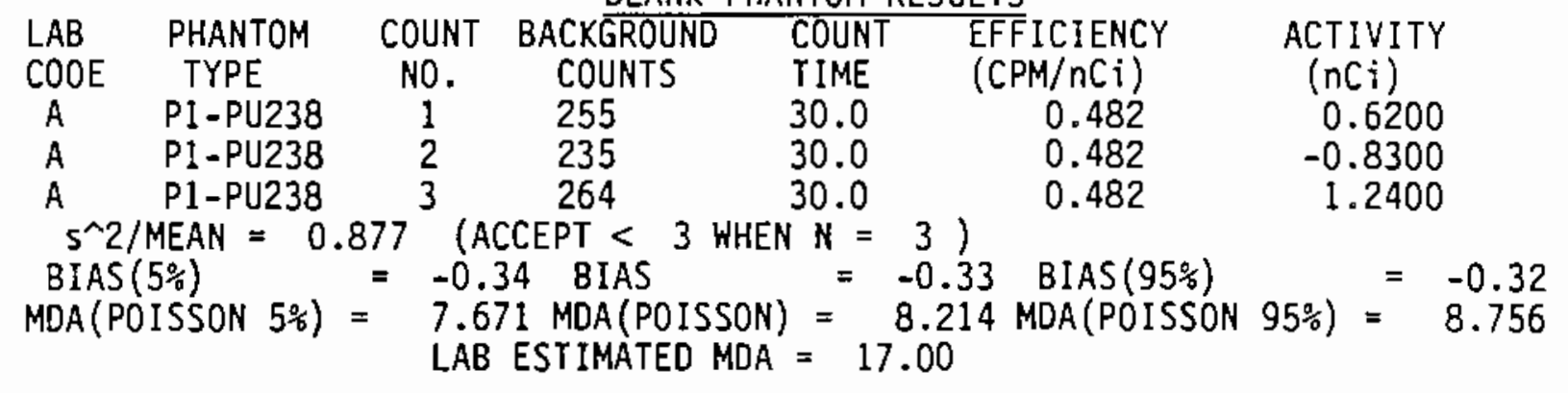

$\begin{array}{lccccc}\text { LAB } & \text { PHANTOM } & \text { COUNT } & \begin{array}{c}\text { DATE } \\ \text { COUNTED }\end{array} & \begin{array}{c}\text { LAB ASSAY } \\ \text { (nCi) }\end{array} \\ \text { CO0E } & \text { TYPE } & \text { NO. } & \text { ERR } \\ \text { B2 } & \text { M1-CE144 } & 1 & 9-14-87 & 1411.00 \\ \text { B2 } & \text { M1-CE144 } & 2 & 9=14-87 & 1424.00 \\ \text { B2 } & \text { M1-CE144 } & 3 & 9-14-87 & 1466.00 \\ \text { B2 } & \text { M1-CE144 } & 4 & 9-14-87 & 1363.00 \\ \text { B2 } & \text { M1-CE144 } & 5 & 9-14-87 & 1338.00 \\ \text { MEAN }=1400.4 & \text { Lab Est. Re1. Error }= & 0.05 \\ \text { BR }(5 \%)= & 1.07 & \text { BR }= & 1.15 & \text { BR }(95 \%)= & 1.22 \\ \text { SA }(5 \%)= & 0.02 & \text { SA }= & 0.04 & \text { SA }(95 \%)= & 0.09 \\ \text { SB }(5 \%)= & 0.05 & \text { SB }= & 0.08 & \text { SB }(95 \%)= & 0.18\end{array}$

\begin{tabular}{|c|c|c|c|c|c|c|}
\hline $\begin{array}{l}\text { LAB } \\
\text { CODE } \\
\text { B1 } \\
\text { B1 } \\
\text { B1 } \\
\text { B1 } \\
\text { B1 }\end{array}$ & $\begin{array}{l}\text { PHANTOM } \\
\text { TYPE } \\
W 1-C S 134 \\
W 1-C S 134 \\
W 1-C S 134 \\
W 1-C S 134 \\
W 1-C S 134\end{array}$ & $\begin{array}{c}\text { COUNT } \\
\text { NO. } \\
1 \\
2 \\
3 \\
4 \\
5\end{array}$ & $\begin{array}{c}\text { DATE } \\
\text { COUNTEO } \\
4-17=87 \\
4-17=87 \\
4-17=87 \\
4-17=87 \\
4-17=87\end{array}$ & $\begin{array}{c}\text { LAB ASSAY } \\
(n C i) \\
289.00 \\
229.00 \\
249.00 \\
254.00 \\
253.00\end{array}$ & $\begin{array}{l}\text { ERROR }(\%) \\
5.40 \\
5.00 \\
5.70 \\
5.40 \\
5.60\end{array}$ & $\begin{array}{l}\text { TRUE } \\
\text { SPIKE } \\
231.99\end{array}$ \\
\hline
\end{tabular}

MEAN $=254.8 \quad$ Lab Est. Rel. Error $=0.05$
BR $(5 \%)=0.01$ BR $=0.10 \mathrm{BR}(95 \%)=0.19$
SA $5 \%)=0.06$ SA $=0.08 \mathrm{SA}(95 \%)=0.20$
SB $(5 \%)=0.06 \mathrm{SB}=0.09 \mathrm{SB}(95 \%)=0.22$

$\begin{array}{ccccccc}\text { LAB } & \text { PHANTOM } & \text { COUNT } & \text { DATE } & \text { LAB ASSAY } & \text { ERROR }(\%) & \text { TRUE } \\ \text { CODE } & \text { TYPE } & \text { NO. } & \text { COUNTED } & \text { (nCi) } & & \text { SPIKE } \\ \text { B1 } & \text { W1-CS137 } & 1 & 4-17-87 & 369.00 & 3.80 & 354.56 \\ \text { B1 } & W 1-C S 137 & 2 & 4-17-87 & 466.00 & 3.30 & 354.56 \\ \text { B1 } & W 1-C S 137 & 3 & 4-17-87 & 415.00 & 3.70 & 354.56 \\ \text { B1 } & W 1-C S 137 & 4 & 4-17-87 & 403.00 & 4.10 & 354.56 \\ \text { B1 } & W 1-C S 137 & 5 & 4-17-87 & 410.00 & 3.60 & 354.56\end{array}$

MEAN $=412.6 \quad$ Lab Est. Re. Error $=0.04$
BR $(5 \%)=0.07$ BR $=0.16$ BR $(95 \%)=0.26$
SA $(5 \%)=0.05$ SA $=0.08$ SA $(95 \%)=0.20$
SB $(5 \%)=0.06$ SB $=0.10 \mathrm{SB}(95 \%)=0.23$




$\begin{array}{ccccccc}\text { LAB } & \text { PHANTOM } & \text { COUNT } & \text { DATE } & \text { LAB ASSAY } & \text { ERROR(\%) } & \text { TRUE } \\ \text { COOE } & \begin{array}{c}\text { TYPE } \\ \text { NOC }\end{array} & \text { NO. } & \text { COUNTED } & \text { SPIKE } \\ \text { B2 } & \text { W1-CS134 } & 1 & 4-17-87 & 42.00 & 6.60 & 231.99 \\ \text { B2 } & \text { W1-CS134 } & 2 & 4-17-87 & 74.00 & 5.80 & 231.99 \\ \text { B2 } & \text { W1-CS134 } & 3 & 4-17-87 & 63.00 & 5.40 & 231.99 \\ \text { B2 } & \text { W1-CS134 } & 4 & 4-17-87 & 79.00 & 5.30 & 231.99 \\ \text { B2 } & \text { W1-CS134 } & 5 & 4-17-87 & 59.00 & 6.30 & 231.99\end{array}$

\begin{tabular}{|c|c|c|c|c|c|c|c|c|}
\hline $\begin{array}{l}\text { MEAN } \\
\text { BR (5\%) } \\
\text { SA (5\%) } \\
\text { SB (5\%) }\end{array}$ & $\begin{array}{l}= \\
= \\
= \\
=\end{array}$ & $\begin{array}{r}63.4 \\
-0.79 \\
0.15 \\
0.04\end{array}$ & $\begin{array}{l}B R \\
S A \\
S B\end{array}$ & $\begin{array}{l}\text { Lab } \\
= \\
= \\
=\end{array}$ & $\begin{array}{r}\text { Est. } \\
-0.73 \\
0.23 \\
0.06\end{array}$ & $\begin{array}{l}\text { Rel. } \\
\text { BR } \\
\text { SA } \\
\text { SB }\end{array}$ & $\begin{array}{l}\text { Error } \\
\left(95^{\circ}\right) \\
\left(95^{\circ}\right) \\
\left(95^{\circ}\right)\end{array}$ & \\
\hline
\end{tabular}

\begin{tabular}{|c|c|c|c|c|c|c|}
\hline $\begin{array}{l}\mathrm{LAB} \\
\mathrm{CODE} \\
\mathrm{B} 2 \\
\mathrm{~B} 2 \\
\mathrm{~B} 2 \\
\mathrm{~B} 2 \\
\mathrm{~B} 2\end{array}$ & $\begin{array}{l}\text { PHANTOM } \\
\text { TYPE } \\
\text { W1-CS137 } \\
W 1-C S 137 \\
W 1-C S 137 \\
W 1-C S 137 \\
W 1-C S 137\end{array}$ & $\begin{array}{c}\text { COUNT } \\
\text { NO. } \\
1 \\
2 \\
3 \\
4 \\
5\end{array}$ & $\begin{array}{c}\text { DATE } \\
\text { COUNTED } \\
4-17-87 \\
4-17-87 \\
4-17-87 \\
4-17-87 \\
4-17-87\end{array}$ & $\begin{array}{c}\text { LAB ASSAY } \\
(\mathrm{nCi}) \\
77.00 \\
89.00 \\
108.00 \\
76.00 \\
110.00\end{array}$ & $\begin{array}{l}4.50 \\
4.90 \\
4.20 \\
5.30 \\
3.80\end{array}$ & $\begin{array}{c}\text { TRUE } \\
\text { SPIKE } \\
354.56 \\
354.56 \\
354.56 \\
354.56 \\
354.56\end{array}$ \\
\hline
\end{tabular}

\begin{tabular}{|c|c|c|c|c|c|c|c|c|c|}
\hline $\begin{array}{l}\text { MEAN } \\
\text { BR } \quad(5 \%) \\
\text { SA } \quad(5 \%) \\
\text { SB } \quad(5 \%)\end{array}$ & $\begin{array}{l}= \\
=\end{array}$ & $\begin{array}{c}92.0 \\
-0.78 \\
0.12 \\
0.03\end{array}$ & $\begin{array}{l}B R \\
S A \\
S B\end{array}$ & $\begin{array}{l}\text { Lab } \\
= \\
= \\
=\end{array}$ & $\begin{array}{r}\text { Est. } \\
-0.74 \\
0.18 \\
0.05\end{array}$ & $\begin{array}{l}\mathrm{Re} T \text {. } \\
\text { BR } \\
\text { SA } \\
\text { SB }\end{array}$ & $\begin{array}{l}\text { Error } \\
(95 \%) \\
(95 \%) \\
(95 \%)\end{array}$ & $\begin{array}{l}= \\
=\end{array}$ & $\begin{array}{r}0.05 \\
-0.70 \\
0.42 \\
0.11\end{array}$ \\
\hline
\end{tabular}

$\begin{array}{ccccccc}\text { LAB } & \text { PHANTOM } & \text { COUNT } & \text { DATE } & \text { LAB ASSAY } & \text { ERROR }(\%) & \text { TRUE } \\ \text { CODE } & \text { TYPE } & \text { NO. } & \text { COUNTED } & (\mathrm{nCi}) & & \text { SPIKE } \\ \text { B2 } & \text { W1-CS134 } & 1 & 4-17-87 & 70.00 & 4.40 & 231.99 \\ \text { B2 } & \text { W1-CS134 } & 2 & 4-17-87 & 108.00 & 5.00 & 231.99 \\ \text { B2 } & \text { W1-CS134 } & 3 & 4-17-87 & 78.00 & 5.20 & 231.99 \\ \text { B2 } & \text { W1-CS134 } & 4 & 4-17-87 & 68.00 & 4.90 & 231.99 \\ \text { B2 } & \text { W1-CS134 } & 5 & 4-17-87 & 77.00 & 5.20 & 231.99\end{array}$

\begin{tabular}{|c|c|c|c|c|c|c|c|c|}
\hline $\begin{array}{l}\text { MEAN } \\
\text { BR }(5 \%) \\
\text { SA } \quad(5 \%) \\
\text { SB }(5 \%)\end{array}$ & $=$ & $\begin{array}{r}80.2 \\
-0.72 \\
0.13 \\
0.05\end{array}$ & $\begin{array}{l}\text { BR } \\
\text { SA } \\
\text { SB }\end{array}$ & $\begin{array}{l}\text { Lab } \\
= \\
= \\
=\end{array}$ & $\begin{array}{l}\text { Est. } \\
-0.65 \\
0.20 \\
0.07\end{array}$ & $\begin{array}{r}\text { Rel. } \\
\text { BR } \\
\text { SA } \\
\text { SB }\end{array}$ & $\begin{array}{l}\text { Error } \\
(95 \%) \\
(95 \%) \\
(95 \%)\end{array}$ & \\
\hline
\end{tabular}

$\begin{array}{ccccccr}\text { LAB } & \text { PHANTOM } & \text { COUNT } & \text { DATE } & \text { LAB ASSAY } & \text { ERROR }(\%) & \text { TRUE } \\ \text { CODE } & \text { TYPE } & \text { NO. } & \text { COUNTED } & \text { (nCi) } & & \text { SPIKE } \\ \text { B2 } & \text { W1-CS137 } & 1 & 4-17-87 & 130.00 & 3.70 & 354.56 \\ \text { B2 } & \text { W1-CS137 } & 2 & 4-17-87 & 119.00 & 4.40 & 354.56 \\ \text { B2 } & \text { W1-CS137 } & 3 & 4-17-87 & 150.00 & 3.60 & 354.56 \\ \text { B2 } & \text { W1-CS137 } & 4 & 4-17-87 & 170.00 & 3.50 & 354.56 \\ \text { B2 } & \text { W1-CS137 } & 5 & 4-17-87 & 155.00 & 3.40 & 354.56\end{array}$

$\begin{array}{lllll}\text { MEAN }= & 144.8 & \text { Lab Est. ReT. Error }= & 0.04 \\ \text { BR }(5 \%)= & -0.65 \text { BR }= & -0.59 \text { BR }(95 \%)= & -0.54 \\ \text { SA }(5 \%)= & 0.09 & \text { SA }= & 0.14 \text { SA }(95 \%)= & 0.33 \\ \text { SB }(5 \%)= & 0.04 & \text { SB }= & 0.06 \text { SB }(95 \%)= & 0.14\end{array}$




$\begin{array}{ccccccc}\text { LAB } & \text { PHANTOM } & \text { COUNT } & \text { DATE } & \text { LAB ASSAY } & \text { ERROR(\%) } & \text { TRUE } \\ \text { COOE } & \text { TYPE } & \text { N0. } & \text { COUNTED } & \text { (nCi) } & & \text { SPIKE } \\ \text { B1 } & \text { M2-CE144 } & 1 & 9-14-87 & 159.00 & 20.30 & 75.64 \\ \text { B1 } & \text { M2-CE144 } & 2 & 9-14-87 & 305.00 & 14.50 & 75.64 \\ \text { B1 } & \text { M2-CE144 } & 3 & 9-14-87 & 157.00 & 22.70 & 75.64 \\ \text { B1 } & \text { M2-CE144 } & 4 & 9-14-87 & 189.00 & 22.00 & 75.64\end{array}$

\begin{tabular}{|c|c|c|c|c|c|c|c|c|}
\hline $\begin{array}{l}\text { MEAN } \\
\text { BR }(5 \%) \\
\text { SA }(5 \%) \\
\text { SB }(5 \%)\end{array}$ & $\begin{array}{l}= \\
= \\
=\end{array}$ & $\begin{array}{r}202.5 \\
0.59 \\
0.21 \\
0.57\end{array}$ & $\begin{array}{l}\text { BR } \\
\text { SA } \\
\text { SB }\end{array}$ & $\begin{array}{l}\text { Lab } \\
= \\
= \\
=\end{array}$ & $\begin{array}{c}\text { Est. } \\
1.68 \\
0.35 \\
0.92\end{array}$ & $\begin{array}{l}\text { Rel. } \\
\text { BR } \\
\text { SA } \\
\text { SB }\end{array}$ & $\begin{array}{l}\text { Error } \\
(95 \%) \\
(95 \%) \\
(95 \%)\end{array}$ & \\
\hline
\end{tabular}

\begin{tabular}{|c|c|c|c|c|c|}
\hline $\begin{array}{l}\text { LAB } \\
\text { COOE } \\
\text { B1 } \\
\text { B1 } \\
\text { B1 } \\
\text { B1 } \\
\text { B1 }\end{array}$ & $\begin{array}{l}\text { PHANTOM } \\
\text { TYPE } \\
\text { M1-CE144 } \\
\text { M1-CE144 } \\
\text { M1-CE144 } \\
\text { M1-CE144 } \\
\text { M1-CE144 }\end{array}$ & $\begin{array}{c}\text { COUNT } \\
\text { NO. } \\
1 \\
2 \\
3 \\
4 \\
5\end{array}$ & $\begin{array}{c}\text { DATE } \\
\text { COUNTED } \\
9-14=87 \\
9-14=87 \\
9-14=87 \\
9-14-87 \\
9-14=87\end{array}$ & $\begin{array}{c}\text { LAB ASSAY } \\
\text { (nCi) } \\
1219.00 \\
793.00 \\
967.00 \\
1091.00 \\
1265.00\end{array}$ & $\begin{array}{c}\text { ERROR }(\%) \\
8.90 \\
14.50 \\
9.80 \\
8.90 \\
8.60\end{array}$ \\
\hline
\end{tabular}

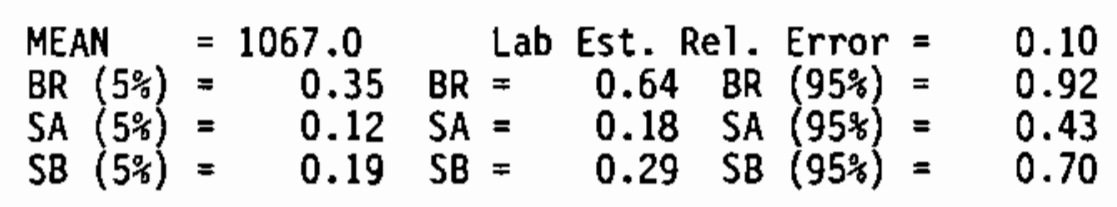

\begin{tabular}{ccccccr} 
LAB & PHANTOM & COUNT & OATE & LAB ASSAY & ERROR(\%) & \multicolumn{1}{c}{ TRUE } \\
CODE & TYPE & N0. & COUNTED & $($ nCi) & & SPIKE \\
B2 & M1-CE144 & 1 & $9-14-87$ & 1411.00 & 4.30 & 652.55 \\
B2 & M1-CE144 & 2 & $9-14-87$ & 1424.00 & 4.60 & 652.55 \\
B2 & M1-CE144 & 3 & $9-14-87$ & 1466.00 & 4.30 & 652.55 \\
B2 & M1-CE144 & 4 & $9-14-87$ & 1363.00 & 5.10 & 652.55 \\
B2 & M1-CE144 & 5 & $9-14-87$ & 1338.00 & 4.60 & 652.55
\end{tabular}

\begin{tabular}{|c|c|c|c|c|c|c|c|}
\hline $\begin{array}{l}\text { MEAN } \\
\text { BR } \quad(5 \%) \\
\text { SA } \quad(5 \%) \\
\text { SB }(5 \%)\end{array}$ & $\begin{array}{lr}= & 1400.4 \\
= & 1.07 \\
= & 0.02 \\
= & 0.05\end{array}$ & $\begin{array}{l}\text { BR } \\
\text { SA } \\
\text { SB }\end{array}$ & $\begin{array}{l}\text { Lab } \\
= \\
= \\
=\end{array}$ & $\begin{array}{ll}\text { Est. } & \text { Re } . \\
1.15 & \text { BR } \\
0.04 & \text { SA } \\
0.08 & \text { SB }\end{array}$ & $\begin{array}{l}\text { Error } \\
(95 \%) \\
(95 \%) \\
(95 \%)\end{array}$ & $\begin{array}{l}= \\
= \\
=\end{array}$ & $\begin{array}{l}0.05 \\
1.22 \\
0.09 \\
0.18\end{array}$ \\
\hline
\end{tabular}

$\begin{array}{lcccccc}\text { LAB } & \text { PHANTOM } & \text { COUNT } & \text { DATE } & \text { LAB ASSAY } & \text { ERROR }(\%) & \text { TRUE } \\ \text { CODE } & \begin{array}{c}\text { TYPE } \\ \text { NOPI }\end{array} & \text { N0. } & \text { COUNTED } & \text { (nCi) } & & \text { SPIKE } \\ \text { B2 } & \text { M1-MN54 } & 1 & 9-14-87 & 575.00 & 1.10 & 247.86 \\ \text { B2 } & \text { M1-MN54 } & 2 & 9-14-87 & 362.00 & 1.30 & 247.86 \\ \text { B2 } & \text { M1-MN54 } & 3 & 9-14-87 & 382.00 & 1.40 & 247.86 \\ \text { B2 } & \text { M1-MN54 } & 4 & 9-14-87 & 595.00 & 1.00 & 247.86 \\ \text { B2 } & \text { M1-MN54 } & 5 & 9-14-87 & 585.00 & 1.00 & 247.86\end{array}$

\begin{tabular}{|c|c|c|c|c|c|c|c|}
\hline $\begin{array}{l}\text { MEAN } \\
\text { BR }(5 \%) \\
\text { SA }(5 \%) \\
\text { SB }(5 \%)\end{array}$ & $\begin{array}{l}= \\
= \\
= \\
=\end{array}$ & $\begin{array}{r}499.8 \\
0.57 \\
0.15 \\
0.31\end{array}$ & $\begin{array}{l}B R \\
\text { SA } \\
\text { SB }\end{array}$ & $\begin{array}{l}\text { Lab } \\
= \\
= \\
=\end{array}$ & $\begin{array}{c}\text { Est. } \\
1.02 \\
0.23 \\
0.47\end{array}$ & $\begin{array}{l}\text { Rel } \\
\mathrm{BF} \\
\mathrm{SA} \\
\mathrm{SE}\end{array}$ & $\begin{array}{l}\text { Error } \\
(95 \%) \\
(95 \%) \\
(95 \%)\end{array}$ \\
\hline
\end{tabular}




\begin{tabular}{|c|c|c|c|c|c|c|c|}
\hline $\begin{array}{l}\text { LAB } \\
\text { CODE } \\
\text { B1 } \\
\text { B1 } \\
\text { B1 } \\
\text { B1 }\end{array}$ & $\begin{array}{c}\text { PHANTOM } \\
\text { TYPE } \\
\text { M1-MN54 } \\
\text { M1-MN54 } \\
\text { M1-MN54 } \\
\text { M1-MN54 }\end{array}$ & $\begin{array}{c}\text { COUNT } \\
\text { NO. } \\
1 \\
2 \\
3 \\
4\end{array}$ & $\begin{array}{l}9 \\
9 \\
9 \\
9\end{array}$ & $\begin{array}{l}\text { DATE } \\
\text { COUNTEO } \\
=14-87 \\
-14-87 \\
-14-87 \\
=14-87\end{array}$ & $\begin{array}{c}\text { LAB ASSAY } \\
(n C i) \\
333.00 \\
348.00 \\
294.00 \\
291.00\end{array}$ & $\begin{array}{l}2.40 \\
2.40 \\
3.00 \\
2.90\end{array}$ & $\begin{array}{l}\text { TRUE } \\
\text { SPIKE } \\
247.86 \\
247.86 \\
247.86 \\
247.86\end{array}$ \\
\hline
\end{tabular}

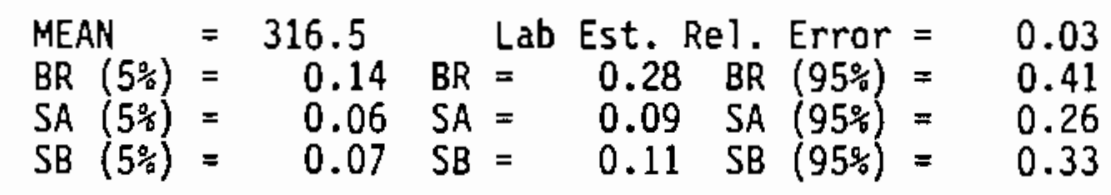

\begin{tabular}{|c|c|c|c|c|c|c|}
\hline $\begin{array}{l}\text { LAB } \\
\text { CODE } \\
C \\
C \\
C \\
C \\
C\end{array}$ & $\begin{array}{l}\text { PHANTOM } \\
\text { TYPE } \\
\text { MI-CE144 } \\
\text { M1-CE144 } \\
\text { M1-CE144 } \\
\text { M1-CE144 } \\
\text { M1-CE144 }\end{array}$ & $\begin{array}{c}\text { COUNT } \\
\text { NO. } \\
1 \\
2 \\
3 \\
4 \\
5\end{array}$ & $\begin{array}{c}\text { DATE } \\
\text { COUNTED } \\
\begin{aligned} 3-17-87 \\
3-17-87 \\
3-17=87 \\
3-17-87 \\
3-17=87\end{aligned}\end{array}$ & $\begin{array}{c}\text { LAB ASSAY } \\
(n C i) \\
383.00 \\
402.00 \\
507.00 \\
356.00 \\
490.00\end{array}$ & $\begin{array}{l}\text { ERROR }(\%) \\
25.00 \\
25.00 \\
25.00 \\
25.00 \\
25.00\end{array}$ & $\begin{array}{c}\text { TRUE } \\
\text { SPIKE } \\
528.71 \\
528.71 \\
528.71 \\
521.03 \\
521.03\end{array}$ \\
\hline
\end{tabular}

\begin{tabular}{|c|c|c|c|c|c|c|c|c|}
\hline $\begin{array}{l}\text { MEAN } \\
\text { BR } \quad(5 \%) \\
\text { SA } \quad(5 \%) \\
\text { SB }(5 \%)\end{array}$ & $\begin{array}{l}= \\
= \\
=\end{array}$ & $\begin{array}{r}427.6 \\
-0.31 \\
0.10 \\
0.08\end{array}$ & $\begin{array}{l}\text { BR } \\
\text { SA } \\
\text { SB }\end{array}$ & $\begin{array}{l}\text { Lab } \\
= \\
= \\
=\end{array}$ & $\begin{array}{r}\text { Est. } \\
-0.19 \\
0.16 \\
0.13\end{array}$ & $\begin{array}{l}\text { Rel. } \\
\text { BR } \\
\text { SA } \\
\text { SB }\end{array}$ & $\begin{array}{l}\text { Error } \\
(95 \%) \\
(95 \%) \\
(95 \%)\end{array}$ & \\
\hline
\end{tabular}

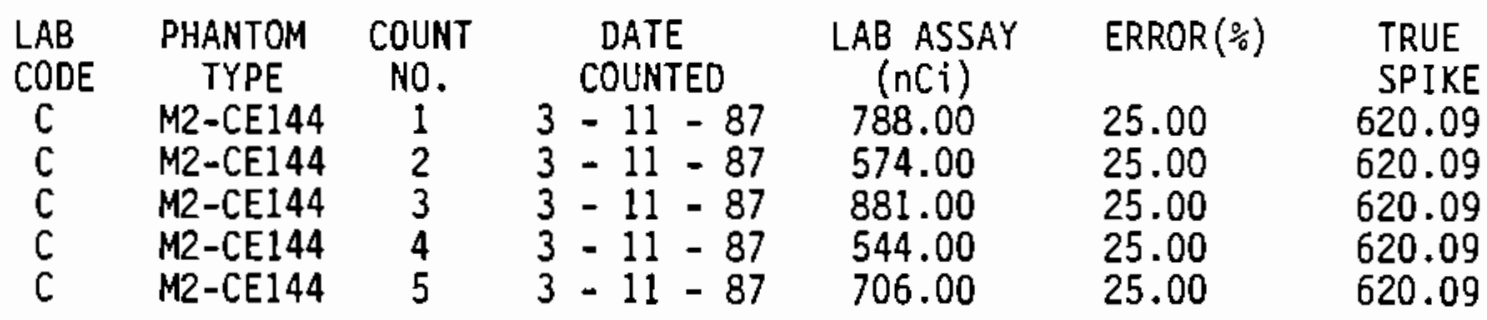

\begin{tabular}{|c|c|c|c|c|c|c|c|}
\hline $\begin{array}{l}\text { MEAN } \\
\text { BR } \quad(5 \%) \\
\text { SA } \quad(5 \%) \\
\text { SB }(5 \%)\end{array}$ & $\begin{array}{lr}= & 698.6 \\
= & -0.09 \\
= & 0.13 \\
= & 0.15\end{array}$ & $\begin{array}{l}\text { BR } \\
\text { SA } \\
\text { SB }\end{array}$ & $\begin{array}{l}\text { Lab } \\
= \\
= \\
=\end{array}$ & $\begin{array}{c}\text { Est. } \\
0.13 \\
0.20 \\
0.23\end{array}$ & $\begin{array}{r}\text { Rel. } \\
\text { BR } \\
\text { SA } \\
\text { SB }\end{array}$ & $\begin{array}{l}\text { Error } \\
(95 \%) \\
(95 \%) \\
(95 \%)\end{array}$ & \\
\hline
\end{tabular}

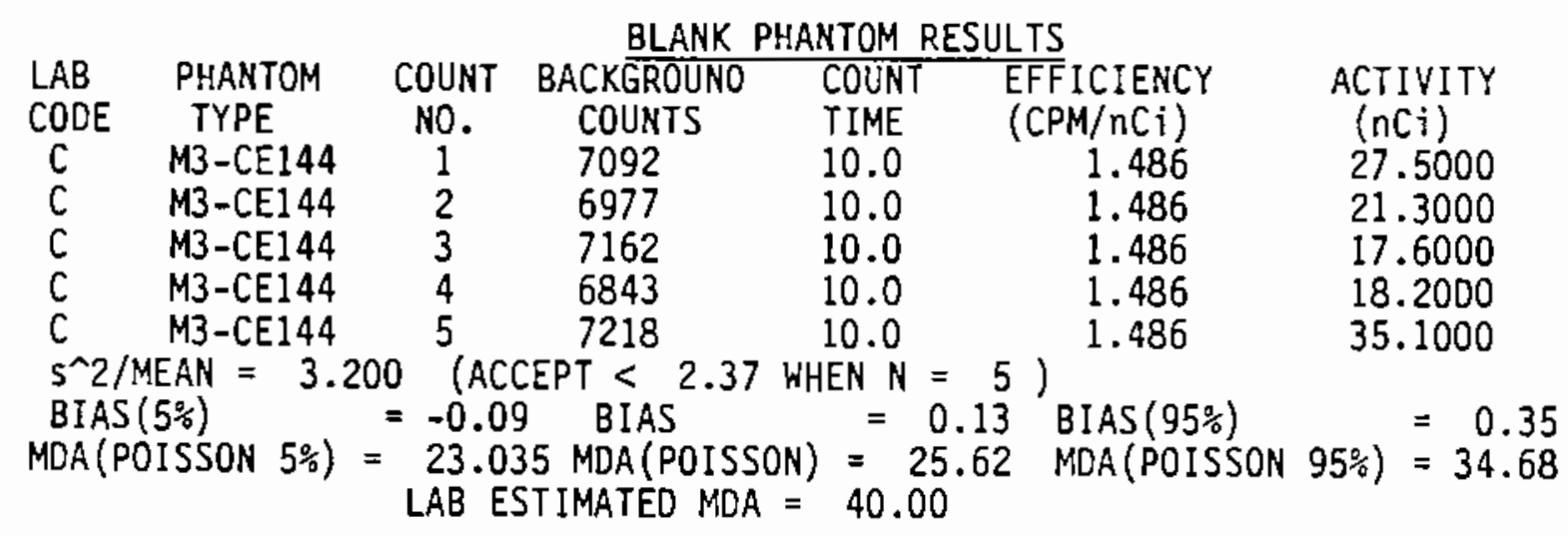




$\begin{array}{lcccccc}\text { LAB } & \text { PHANTOM } & \text { COUNT } & \text { DATE } & \text { LAB ASSAY } & \text { ERROR }(\%) & \text { TRUE } \\ \text { CODE } & \text { TYPE } & \text { NO. } & \text { COUNTED } & \text { (nCi) } & & \text { SPIKE } \\ \text { C } & \text { M1-MN54 } & 1 & 3-11-87 & 107.00 & 15.00 & 185.70 \\ \text { C } & \text { M1-MN54 } & 2 & 3-11-87 & 114.00 & 15.00 & 185.70 \\ \text { C } & \text { M1-MN54 } & 3 & 3-11-87 & 120.00 & 15.00 & 185.70 \\ \text { C } & \text { M1-MN54 } & 4 & 3-11-87 & 68.00 & 15.00 & 185.70 \\ C & \text { M1-MN54 } & 5 & 3-11-87 & 133.00 & 15.00 & 185.70\end{array}$

\begin{tabular}{|c|c|c|c|c|c|c|c|c|}
\hline $\begin{array}{l}\text { MEAN } \\
\text { BR }(5 \%) \\
\text { SA }(5 \%) \\
\text { SB (5\%) }\end{array}$ & $\begin{array}{l}= \\
= \\
=\end{array}$ & $\begin{array}{r}108.4 \\
-0.54 \\
0.15 \\
0.09\end{array}$ & $\begin{array}{l}\text { BR } \\
S A \\
S B\end{array}$ & $\begin{array}{l}\text { Lab } \\
= \\
= \\
=\end{array}$ & $\begin{array}{l}\text { Est. } \\
-0.42 \\
0.23 \\
0.13\end{array}$ & $\begin{array}{ll}\text { Rel } & \text { BR } \\
2 & \text { BR } \\
3 & \text { SA } \\
3 & \text { SB }\end{array}$ & $\begin{array}{l}\text { Error } \\
(95 \%) \\
(95 \%) \\
(95 \%)\end{array}$ & \\
\hline
\end{tabular}

$\begin{array}{ccccccc}\text { LAB } & \text { PHANTOM } & \text { COUNT } & \text { DATE } & \text { LAB ASSAY } & \text { ERROR } \% \text { ( }) & \text { TRUE } \\ \text { CODE } & \begin{array}{c}\text { TYPE } \\ \text { NO. }\end{array} & \text { COUNTED } & \text { (nCi) } & & \text { SPIKE } \\ \text { C } & \text { M2-MN54 } & 1 & 3-11-87 & 198.00 & 15.00 & 226.21 \\ \text { C } & \text { M2-MN54 } & 2 & 3-11-87 & 202.00 & 15.00 & 226.21 \\ \text { C } & \text { M2-MN54 } & 3 & 3-11-87 & 218.00 & 15.00 & 226.21 \\ \text { C } & \text { M2-MN54 } & 4 & 3-11-87 & 183.00 & 15.00 & 226.21 \\ \text { C } & \text { M2-MN54 } & 5 & 3-11-87 & 182.00 & 15.00 & 226.21\end{array}$

$\begin{array}{lrrrrr}\text { MEAN }= & 196.6 & \text { Lab Est. Re1. Error }= & 0.15 \\ \text { BR }(5 \%)= & -0.19 & \text { BR }= & -0.13 & \text { BR }(95 \%)= & -0.07 \\ \text { SA }(5 \%)= & 0.05 & \text { SA }= & 0.08 & \text { SA }(95 \%)= & 0.18 \\ \text { SB }(5 \%)= & 0.04 & \text { SB }= & 0.07 & \text { SB }(95 \%)= & 0.16\end{array}$

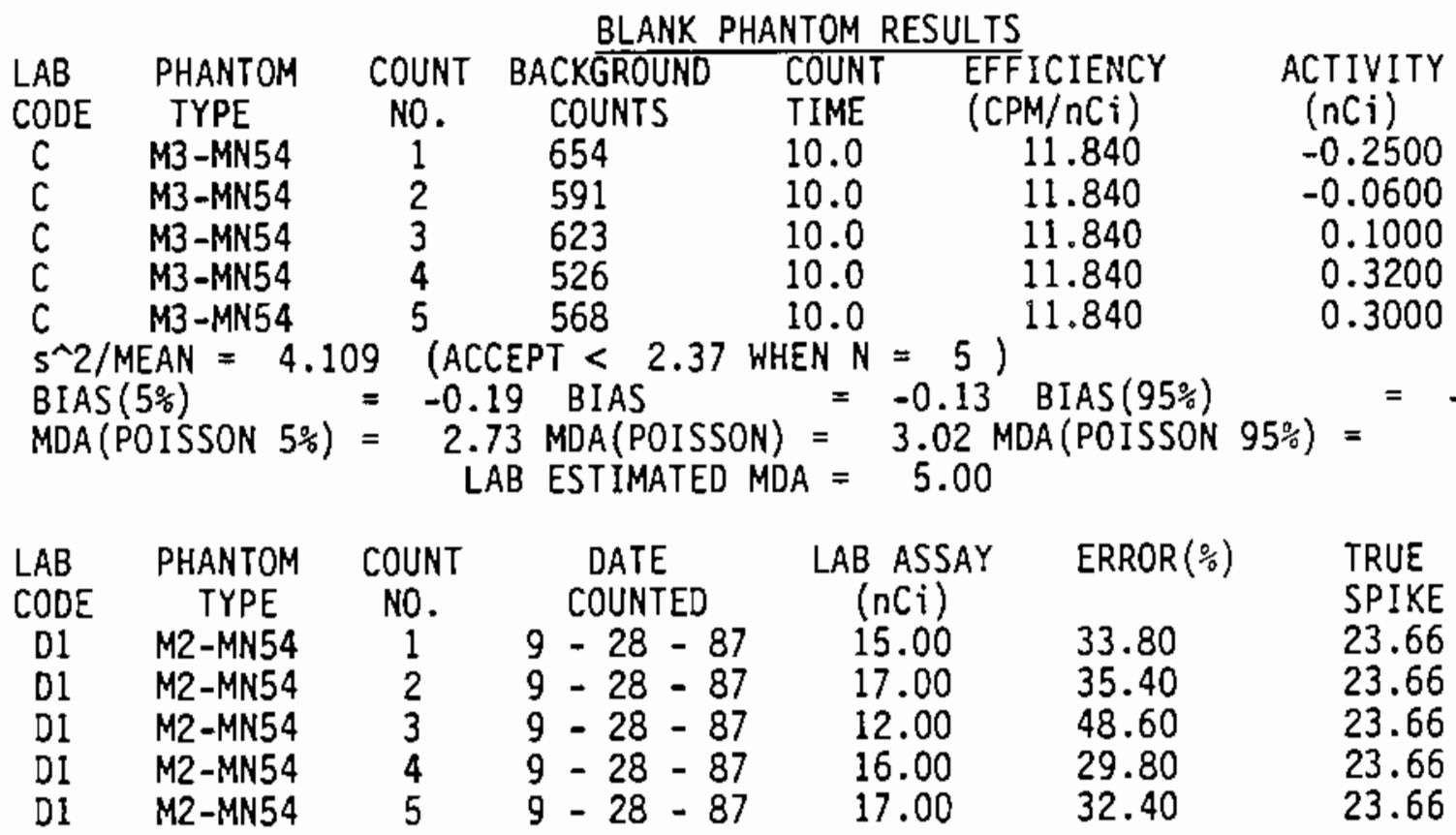

$\begin{array}{lrlll}\text { MEAN }= & 15.4 & \text { Lab Est. Rel. Error }= & 0.36 \\ \text { BR }(5 \%)= & -0.43 \text { BR }= & -0.35 \text { BR }(95 \%)= & -0.27 \\ \text { SA }(5 \%)= & 0.09 & \text { SA }= & 0.13 \text { SA }(95 \%)= & 0.32 \\ \text { SB }(5 \%)= & 0.06 \text { SB }= & 0.09 \text { SB }(95 \%)= & 0.21\end{array}$




$\begin{array}{lcccccc}\text { LAB } & \text { PHANT0M } & \text { COUNT } & \text { DATE } & \text { LAB ASSAY } & \text { ERROR }(\%) & \text { TRUE } \\ \text { CODE } & \text { TYPE } & \text { NO. } & \text { COUNTED } & (\mathrm{nCi}) & & \text { SPIKE } \\ \text { D1 } & \text { M1-MN54 } & 1 & 9-28-87 & 230.00 & 9.00 & 240.29 \\ \text { D1 } & \text { M1-MN54 } & 2 & 9-28-87 & 237.00 & 9.00 & 240.29 \\ \text { D1 } & \text { M1-MN54 } & 3 & 9-28-87 & 230.00 & 8.90 & 240.29 \\ \text { D1 } & \text { M1-MN54 } & 4 & 9-28-87 & 226.00 & 9.00 & 240.29 \\ \text { D1 } & \text { M1-MN54 } & 5 & 9-28-87 & 227.00 & 9.00 & 240.29\end{array}$

\begin{tabular}{|c|c|c|c|c|c|c|c|c|}
\hline $\begin{array}{l}\text { MEAN } \\
\text { BR } \quad(5 \%) \\
\text { SA } \quad(5 \%) \\
\text { SB } \quad(5 \%)\end{array}$ & $\begin{array}{l}= \\
= \\
=\end{array}$ & $\begin{array}{r}230.0 \\
=0.06 \\
0.01 \\
0.01\end{array}$ & $\begin{array}{l}\text { BR } \\
S A \\
S B\end{array}$ & $\begin{array}{l}\text { Lab } \\
= \\
= \\
=\end{array}$ & $\begin{array}{r}\text { Est. } \\
-0.04 \\
0.02 \\
0.02\end{array}$ & $\begin{array}{l}\text { Rel. } \\
\text { BR } \\
\text { SA } \\
\text { SE }\end{array}$ & $\begin{array}{l}\text { Error } \\
(95 \%) \\
(95 \%) \\
(95 \%)\end{array}$ & \\
\hline
\end{tabular}

$\begin{array}{lcccccc}\text { LAB } & \text { PHANTOM } & \text { COUNT } & \text { DATE } & \text { LAB ASSAY } & \text { ERROR(\%) } & \text { TRUE } \\ \text { CODE } & \text { TYPE } & \text { NO. } & \text { COUNTED } & (\mathrm{nCi}) & & \text { SPIKE } \\ \text { D2 } & \text { M2-CE144 } & 1 & 10-1-87 & 50.12 & 27.80 & 72.57 \\ \text { D2 } & \text { M2-CE144 } & 2 & 10-1-87 & 76.42 & 18.50 & 72.57 \\ \text { D2 } & \text { M2-CE144 } & 3 & 10-1-87 & 117.30 & 14.20 & 72.57 \\ \text { D2 } & \text { M2-CE144 } & 4 & 10-1-87 & 144.50 & 12.60 & 72.57 \\ \text { D2 } & \text { M2-CE144 } & 5 & 10-1-87 & 82.14 & 17.20 & 72.57\end{array}$

$\begin{array}{llllll}\text { MEAN } & =94.1 & \text { Lab Est. Re1. Error }= & 0.18 \\ \operatorname{BR}(5 \%)= & -0.19 & \mathrm{BR}= & 0.30 \mathrm{BR}(95 \%)= & 0.78 \\ \text { SA }(5 \%) & =0.26 \mathrm{SA}= & 0.39 \mathrm{SA}(95 \%)= & 0.93 \\ \text { SB }(5 \%)= & 0.33 \mathrm{SB}= & 0.51 \mathrm{SB}(95 \%)= & 1.21\end{array}$

\begin{tabular}{|c|c|c|c|c|c|c|}
\hline $\begin{array}{l}\angle A B \\
\text { CODE } \\
\text { D2 } \\
D 2 \\
D 2 \\
D 2 \\
D 2\end{array}$ & $\begin{array}{l}\text { PHANTOM } \\
\text { TYPE } \\
\text { M1-CE144 } \\
\text { M1-CE144 } \\
\text { M1-CE144 } \\
\text { M1-CE144 } \\
\text { M1-CE144 }\end{array}$ & $\begin{array}{c}\text { COUNT } \\
\text { NO. } \\
1 \\
2 \\
3 \\
4 \\
5\end{array}$ & $\begin{array}{c}\text { DATE } \\
\text { COUNTED } \\
10-2=87 \\
10-2=87 \\
10-2=87 \\
10=2-87 \\
10-2-87\end{array}$ & $\begin{array}{c}\text { LAB ASSAY } \\
\text { (nCi) } \\
534.00 \\
572.60 \\
570.10 \\
547.50 \\
587.20\end{array}$ & $\begin{array}{l}\text { ERROR }(\%) \\
5.50 \\
3.70 \\
5.10 \\
4.40 \\
3.60\end{array}$ & $\begin{array}{c}\text { TRUE } \\
\text { SPIXE } \\
624.53 \\
624.53 \\
624.53 \\
624.53 \\
624.53\end{array}$ \\
\hline
\end{tabular}

\begin{tabular}{|c|c|c|c|c|c|c|c|c|c|}
\hline $\begin{array}{l}\text { MEAN } \\
\text { BR } \quad(5 \%) \\
\text { SA } \quad(5 \%) \\
\text { SB } \quad(5 \%)\end{array}$ & $\begin{array}{l}= \\
=\end{array}$ & $\begin{array}{r}562.3 \\
-0.13 \\
0.02 \\
0.02\end{array}$ & $\begin{array}{l}B R \\
S A \\
S B\end{array}$ & $\begin{array}{l}\text { Lab } \\
= \\
= \\
=\end{array}$ & $\begin{array}{l}\text { Est. } \\
-0.10 \\
0.04 \\
0.03\end{array}$ & $\begin{array}{l}\text { Rel. } \\
\text { BR } \\
\text { SA } \\
\text { SB }\end{array}$ & $\begin{array}{l}\text { Error } \\
(95 \%) \\
(95 \%) \\
(95 \%)\end{array}$ & $\begin{array}{l}= \\
= \\
=\end{array}$ & $\begin{array}{r}0.04 \\
-0.07 \\
0.09\end{array}$ \\
\hline
\end{tabular}

\begin{tabular}{|c|c|c|c|c|c|}
\hline $\begin{array}{l}\mathrm{LAB} \\
\mathrm{CODE} \\
\mathrm{D} 2 \\
\mathrm{D} 2 \\
\mathrm{D} 2 \\
\mathrm{D} 2 \\
\mathrm{D} 2\end{array}$ & $\begin{array}{c}\text { PHANTOM } \\
\text { TYPE } \\
\text { M2-MN54 } \\
\text { M2-MN54 } \\
\text { M2-MN54 } \\
\text { M2-MN54 } \\
\text { M2-MN54 }\end{array}$ & $\begin{array}{c}\text { COUNT } \\
\text { NO. } \\
1 \\
2 \\
3 \\
4 \\
5\end{array}$ & $\begin{array}{c}\text { DATE } \\
\text { COUNTED } \\
10-1-87 \\
10-1-87 \\
10-1-87 \\
10-1-87 \\
10-1-87\end{array}$ & $\begin{array}{c}\text { LAB ASSAY } \\
(n C i) \\
134.20 \\
133.00 \\
136.60 \\
133.00 \\
134.30\end{array}$ & $\begin{array}{l}1.60 \\
1.40 \\
1.40 \\
1.60 \\
1.60\end{array}$ \\
\hline
\end{tabular}

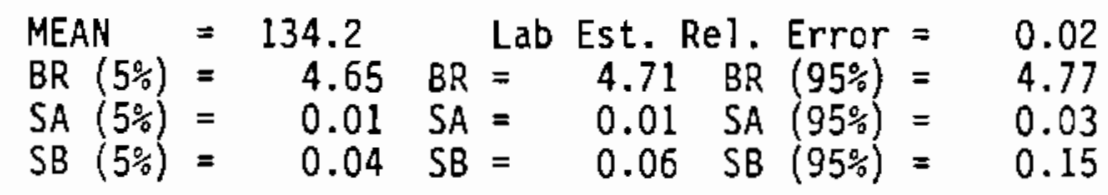




\begin{tabular}{|c|c|c|c|c|c|c|}
\hline $\begin{array}{l}\mathrm{LAB} \\
\mathrm{CODE} \\
\mathrm{D} 2 \\
\mathrm{D} 2 \\
\mathrm{D} 2 \\
\mathrm{D} 2 \\
\mathrm{D} 2\end{array}$ & $\begin{array}{c}\text { PHANTOM } \\
\text { TYPE } \\
\text { MI-MN54 } \\
\text { M1-MN54 } \\
\text { M1-MN54 } \\
\text { M1-MN54 } \\
\text { M1-MN54 }\end{array}$ & $\begin{array}{c}\text { COUNT } \\
\text { NO. } \\
1 \\
2 \\
3 \\
4 \\
5\end{array}$ & $\begin{array}{c}\text { OATE } \\
\text { COUNTED } \\
10=2-87 \\
10=2-87 \\
10-2-87 \\
10-2-87 \\
10-2=87\end{array}$ & $\begin{array}{c}\text { LAB ASSAY } \\
(\mathrm{nC} i) \\
345.10 \\
333.30 \\
334.00 \\
330.90 \\
337.50\end{array}$ & $\begin{array}{l}1.00 \\
1.00 \\
1.00 \\
1.00 \\
1.00\end{array}$ & $\begin{array}{c}\text { TRUE } \\
\text { SPIKE } \\
238.17 \\
238.17 \\
238.17 \\
238.17 \\
238.17\end{array}$ \\
\hline
\end{tabular}

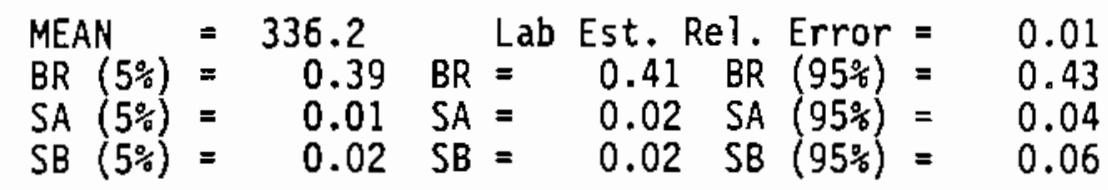

$\begin{array}{lcccccc}\text { LAB } & \text { PHANTOM } & \text { COUNT } & \text { DATE } & \text { LAB ASSAY } & \text { ERROR }(\%) & \text { TRUE } \\ \text { CODE } & \begin{array}{c}\text { TYPE } \\ \text { NO }\end{array} & \text { NO. } & \text { COUNTED } & \text { (nCi) } & & \text { SPIKE } \\ \text { D3 } & \text { M2-MN54 } & 1 & 10-5-87 & 142.90 & 0.60 & 23.29 \\ \text { D3 } & \text { M2-MN54 } & 2 & 10-5-87 & 146.20 & 0.60 & 23.29 \\ \text { D3 } & \text { M2-MN54 } & 3 & 10-5-87 & 147.50 & 0.60 & 23.29 \\ \text { D3 } & \text { M2-MN54 } & 4 & 10-5-87 & 147.40 & 0.60 & 23.29 \\ \text { D3 } & \text { M2-MN54 } & 5 & 10-5-87 & 139.70 & 0.60 & 23.29\end{array}$

\begin{tabular}{|c|c|c|c|c|c|c|c|}
\hline $\begin{array}{l}\text { MEAN } \\
\text { BR } \quad(5 \%) \\
\text { SA } \quad(5 \%) \\
\text { SB } \quad(5 \%)\end{array}$ & $\begin{array}{l}= \\
= \\
= \\
=\end{array}$ & $\begin{array}{r}144.7 \\
5.08 \\
0.02 \\
0.09\end{array}$ & $\begin{array}{l}B R \\
S A \\
S B\end{array}$ & $\begin{array}{l}\text { Lab } \\
= \\
= \\
=\end{array}$ & $\begin{array}{c}\text { Est. } \\
5.21 \\
0.02 \\
0.14\end{array}$ & $\begin{array}{l}\text { Rel } \\
\text { BR } \\
\text { SA } \\
\text { SB }\end{array}$ & $\begin{array}{l}\text { Error } \\
(95 \%) \\
(95 \%) \\
(95 \%)\end{array}$ \\
\hline
\end{tabular}

\begin{tabular}{|c|c|c|c|c|c|c|}
\hline $\begin{array}{l}\angle A B \\
\text { CODE } \\
\text { D3 } \\
\text { D3 } \\
\text { D3 } \\
\text { D3 } \\
\text { D3 }\end{array}$ & $\begin{array}{l}\text { PHANTOM } \\
\text { TYPE } \\
\text { M1-MN54 } \\
\text { M1-MN54 } \\
\text { M1-MN54 } \\
\text { M1-MN54 } \\
\text { M1-MN54 }\end{array}$ & $\begin{array}{c}\text { COUNT } \\
\text { NO. } \\
1 \\
2 \\
3 \\
4 \\
5\end{array}$ & $\begin{array}{c}\text { DATE } \\
\text { COUNTED } \\
10-5-87 \\
10-5=87 \\
10-5-87 \\
10-5=87 \\
10-5-87\end{array}$ & $\begin{array}{c}\text { LAB ASSAY } \\
(\mathrm{nC} \mathrm{i}) \\
374.00 \\
364.50 \\
383.20 \\
362.90 \\
367.00\end{array}$ & $\begin{array}{l}\text { ERROR }(\%) \\
1.00 \\
1.00 \\
1.00 \\
1.00 \\
1.00\end{array}$ & $\begin{array}{l}\text { TRUE } \\
\text { SPIKE } \\
236.59 \\
236.59 \\
236.59 \\
236.59 \\
236.59\end{array}$ \\
\hline
\end{tabular}

$\begin{array}{lllll}\text { MEAN } & =370.3 & \text { Lab Est. Rel. Error }= & 0.01 \\ \text { BR }(5 \%) & =0.53 \text { BR }= & 0.57 \text { BR }(95 \%)= & 0.60 \\ \text { SA }(5 \%)= & 0.01 \text { SA }= & 0.02 & \text { SA }(95 \%)= & 0.05 \\ \text { SB }(5 \%)= & 0.02 \text { SB }= & 0.04 & \text { SB }(95 \%)= & 0.08\end{array}$

\begin{tabular}{|c|c|c|c|c|c|c|}
\hline $\begin{array}{l}\text { LAB } \\
\text { CODE } \\
\text { D3 } \\
\text { D3 } \\
\text { D3 } \\
\text { D3 } \\
\text { D3 }\end{array}$ & $\begin{array}{l}\text { PHANTOM } \\
\text { TYPE } \\
\text { M1-CE144 } \\
\text { M1-CE144 } \\
\text { M1-CE144 } \\
\text { M1-CE144 } \\
\text { M1-CE144 }\end{array}$ & $\begin{array}{c}\text { COUNT } \\
\text { NO. } \\
1 \\
2 \\
3 \\
4 \\
5\end{array}$ & $\begin{array}{c}\text { DATE } \\
\text { COUNTED } \\
10-5-87 \\
10-5-87 \\
10-5=87 \\
10-5-87 \\
10-5-87\end{array}$ & $\begin{array}{c}\text { LAB ASSAY } \\
(\mathrm{nCi}) \\
737.90 \\
831.60 \\
815.80 \\
861.50 \\
824.80\end{array}$ & $\begin{array}{l}6.50 \\
5.60 \\
6.50 \\
6.80 \\
6.50\end{array}$ & $\begin{array}{c}\text { TRUE } \\
\text { SPIKE } \\
619.98 \\
619.98 \\
619.98 \\
619.98 \\
619.98\end{array}$ \\
\hline
\end{tabular}

\begin{tabular}{|c|c|c|c|c|c|c|c|c|}
\hline $\begin{array}{l}\text { MEAN } \\
\text { BR } \quad(5 \%) \\
\text { SA } \quad(5 \%) \\
\text { SB } \quad(5 \%)\end{array}$ & $\begin{array}{l}= \\
= \\
= \\
=\end{array}$ & $\begin{array}{r}814.3 \\
0.24 \\
0.04 \\
0.05\end{array}$ & $\begin{array}{l}B R \\
S A \\
S B\end{array}$ & $\begin{array}{l}\text { Lab } \\
= \\
= \\
=\end{array}$ & $\begin{array}{c}\text { Est. } \\
0.31 \\
0.06 \\
0.07\end{array}$ & \begin{tabular}{ll}
\multicolumn{2}{c}{$\operatorname{Re} 1}$. \\
1 & $\mathrm{BR}$ \\
5 & $\mathrm{SA}$ \\
7 & $\mathrm{SB}$
\end{tabular} & $\begin{array}{l}\text { Error } \\
(95 \%) \\
(95 \%) \\
(95 \%)\end{array}$ & \\
\hline
\end{tabular}




\begin{tabular}{|c|c|c|c|c|c|c|}
\hline $\begin{array}{l}\text { LAB } \\
\text { CODE } \\
\text { D4 } \\
\text { D4 } \\
\text { D4 } \\
\text { D4 } \\
\text { D4 }\end{array}$ & $\begin{array}{c}\text { PHANTOM } \\
\text { TYPE } \\
\text { M2-MN54 } \\
\text { M2-MN54 } \\
\text { M2-MN54 } \\
\text { M2-MN54 } \\
\text { M2-MN54 }\end{array}$ & $\begin{array}{c}\text { COUNT } \\
\text { NO. } \\
1 \\
2 \\
3 \\
4 \\
5\end{array}$ & $\begin{array}{c}\text { DATE } \\
\text { COUNTED } \\
10-10-87 \\
10=10=87 \\
10-10-87 \\
10=10=87 \\
10=10-87\end{array}$ & $\begin{array}{c}\text { LAB ASSAY } \\
(\mathrm{nCi}) \\
29.30 \\
27.00 \\
25.60 \\
27.30 \\
18.70\end{array}$ & $\begin{array}{l}6.00 \\
4.00 \\
3.00 \\
4.00 \\
4.00\end{array}$ & $\begin{array}{l}\text { TRUE } \\
\text { SPIKE } \\
23.03 \\
23.03 \\
23.03 \\
23.03 \\
23.03\end{array}$ \\
\hline
\end{tabular}

\begin{tabular}{|c|c|c|c|c|c|c|c|c|}
\hline $\begin{array}{l}\text { MEAN } \\
\text { BR } \quad(5 \%) \\
\text { SA } \quad(5 \%) \\
\text { SB } \quad(5 \%)\end{array}$ & & $\begin{array}{c}25.6 \\
-0.06 \\
0.10 \\
0.11\end{array}$ & $\begin{array}{l}\text { BR } \\
\text { SA } \\
\text { SB }\end{array}$ & $\begin{array}{l}\text { Lab } \\
= \\
= \\
=\end{array}$ & $\begin{array}{c}\text { Est. } \\
0.11 \\
0.16 \\
0.18\end{array}$ & $\begin{array}{r}\text { Rel. } \\
\text { BR } \\
\text { SA } \\
\text { SB }\end{array}$ & $\begin{array}{l}\text { Error } \\
(95 \%) \\
(95 \%) \\
(95 \%)\end{array}$ & \\
\hline
\end{tabular}

\begin{tabular}{ccccccc} 
LAB & PHANTOM & COUNT & $\begin{array}{c}\text { DATE } \\
\text { COUNTED }\end{array}$ & $\begin{array}{c}\text { LAB ASSAY } \\
(\mathrm{nCi})\end{array}$ & ERROR $(\%)$ & \multicolumn{1}{c}{ TRUE } \\
CODE & TYPE & NO. & COUNE & SPIKE \\
D4 & M1-MN54 & 1 & $10-10-87$ & 216.50 & 8.70 & 233.98 \\
D4 & M1-MN54 & 2 & $10-10-87$ & 212.70 & 8.70 & 233.98 \\
D4 & M1-MN54 & 3 & $10-10-87$ & 227.50 & 9.00 & 233.98 \\
D4 & M1-MN54 & 4 & $10-10-87$ & 209.90 & 9.20 & 233.98 \\
D4 & M1-MN54 & 5 & $10-10-87$ & 223.90 & 8.40 & 233.98
\end{tabular}

$\begin{array}{lllll}\operatorname{MEAN} & =218.1 & \text { Lab Est. Rel. Error }= & 0.09 \\ \mathrm{BR}(5 \%)= & -0.10 & \mathrm{BR}= & -0.07 \text { BR }(95 \%)= & -0.04 \\ \text { SA }(5 \%)= & 0.02 \text { SA }= & 0.03 \text { SA }(95 \%)= & 0.08 \\ \text { SB }(5 \%)= & 0.02 \text { SB }=0.03 \text { SB }(95 \%)= & 0.08\end{array}$

\begin{tabular}{ccccccr} 
LAB & PHANTOM & COUNT & $\begin{array}{c}\text { DATE } \\
\text { COUNTED }\end{array}$ & $\begin{array}{c}\text { LAB ASSAY } \\
(\pi \mathrm{n} \mathrm{j})\end{array}$ & ERROR $\%)$ & \multicolumn{1}{c}{ TRUE } \\
CODE & TYPE & NO. & COUNTE & SPIKE \\
D4 & M1-CE144 & 1 & $10-10-87$ & 707.00 & 10.30 & 612.47 \\
D4 & M1-CE144 & 2 & $10-10-87$ & 558.00 & 10.80 & 612.47 \\
D4 & M1-CE144 & 3 & $10-10-87$ & 569.00 & 10.50 & 612.47 \\
D4 & M1-CE144 & 4 & $10-10-87$ & 687.00 & 8.90 & 612.47 \\
D4 & M1-CE144 & 5 & $10-10-87$ & 608.00 & 9.70 & 612.47
\end{tabular}

$\begin{array}{llllll}\text { MEAN } & =625.8 & \text { Lab Est. Rel. Error }= & 0.10 \\ \text { BR }(5 \%)= & -0.08 & \text { BR }= & 0.02 & \text { BR }(95 \%)= & 0.13 \\ \text { SA }(5 \%)= & 0.07 & \text { SA }= & 0.11 & \text { SA }(95 \%)= & 0.26 \\ \text { SB }(5 \%)= & 0.07 & \mathrm{SB}= & 0.11 & \mathrm{SB}(95 \%)= & 0.26\end{array}$

$\begin{array}{lcccccc}\text { LAB } & \text { PHANTOM } & \text { COUNT } & \text { DATE } & \text { LAB ASSAY } & \text { ERROR(\%) } & \text { TRUE } \\ \text { CODE } & \text { TYPE } & \text { NO. } & \text { COUNTED } & \text { (nCi) } & & \text { SPIKE } \\ \text { D5 } & \text { M2-MN54 } & 1 & 10-10-87 & 19.20 & 18.20 & 23.03 \\ \text { D5 } & \text { M2-MN54 } & 2 & 10-10-87 & 32.80 & 10.40 & 23.03 \\ \text { D5 } & \text { M2-MN54 } & 3 & 10-10-87 & 28.40 & 12.30 & 23.03 \\ \text { D5 } & \text { M2-MN54 } & 4 & 10-10-87 & 23.30 & 17.20 & 23.03 \\ \text { D5 } & \text { M2-MN54 } & 5 & 10-10-87 & 30.00 & 12.70 & 23.03\end{array}$

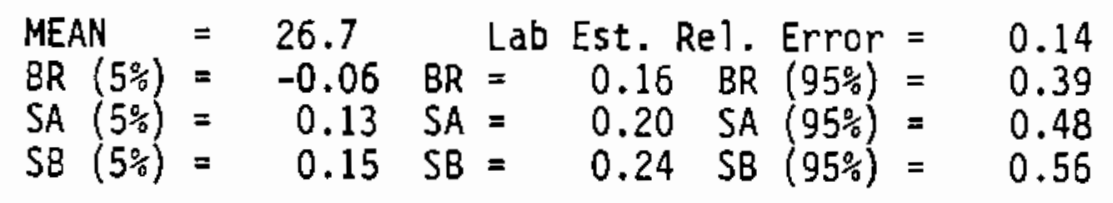




\begin{tabular}{|c|c|c|c|c|c|c|}
\hline $\begin{array}{l}\text { LAB } \\
\text { CODE } \\
\text { D5 } \\
\text { D5 } \\
\text { D5 } \\
\text { D5 } \\
\text { D5 }\end{array}$ & $\begin{array}{c}\text { PHANTOM } \\
\text { TYPE } \\
\text { M1-MN54 } \\
\text { M1-MN54 } \\
\text { M1-MN54 } \\
\text { MI-MN54 } \\
\text { MI-MN54 }\end{array}$ & $\begin{array}{l}\text { COUNT } \\
\text { NO. } \\
1 \\
2 \\
3 \\
4 \\
5\end{array}$ & $\begin{array}{c}\text { DATE } \\
\text { COUNTED } \\
10=10-87 \\
10=10=87 \\
10-10=87 \\
10-10=87 \\
10-10=87\end{array}$ & $\begin{array}{c}\text { LAB ASSAY } \\
(\mathrm{nCi}) \\
247.00 \\
250.00 \\
260.00 \\
260.00 \\
267.00\end{array}$ & $\begin{array}{l}3.90 \\
3.90 \\
3.80 \\
3.80 \\
3.70\end{array}$ & $\begin{array}{c}\text { TRUE } \\
\text { SPIKE } \\
233.98 \\
233.98 \\
233.98\end{array}$ \\
\hline
\end{tabular}

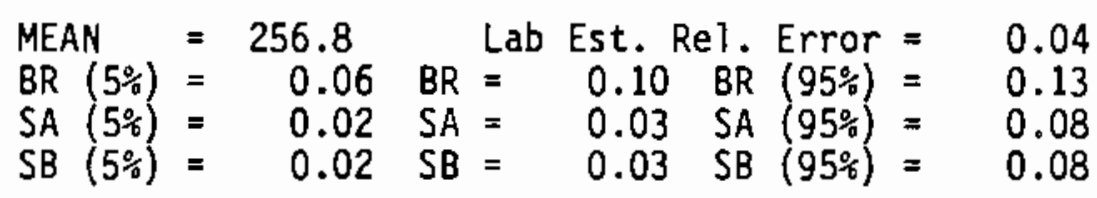

$\begin{array}{llccccc}\text { LAB } & \text { PHANTOM } & \text { COUNT } & \text { DATE } & \text { LAB ASSAY } & \text { ERROR }(\%) & \text { TRUE } \\ \text { CODE } & \text { TYPE } & \text { NO. } & \text { COUNTED } & (n C i) & & \text { SPIKE } \\ \text { D5 } & \text { M2-CE144 } & 1 & 10-10-87 & 71.00 & 36.62 & 71.00 \\ \text { MEAN } & =71.0 & \text { Lab Est. Rel. Error }=0.37 & & \end{array}$

$\begin{array}{ccccccr}\text { LAB } & \text { PHANTOM } & \text { COUNT } & \text { DATE } & \text { LAB ASSAY } & \text { ERROR }(\%) & \text { TRUE } \\ \text { CODE } & \text { TYPE } & \text { NO. } & \text { COUNTED } & \text { (nCi) } & & \text { SPIKE } \\ \text { D5 } & \text { M1-CE144 } & 1 & 10-10-87 & 688.00 & 9.70 & 612.47 \\ \text { D5 } & \text { M1-CE144 } & 2 & 10-10-87 & 679.00 & 13.10 & 612.47 \\ \text { D5 } & \text { M1-CE144 } & 3 & 10-10-87 & 775.00 & 8.50 & 612.47 \\ \text { D5 } & \text { M1-CE144 } & 4 & 10-10-87 & 602.00 & 17.90 & 612.47 \\ \text { D5 } & \text { M1-CE144 } & 5 & 10-10-87 & 741.00 & 9.00 & 612.47\end{array}$

MEAN $=697.0 \quad$ Lab Est. Rel. Error $=0.12$
BR $(5 \%)=0.04$ BR $=0.14$ BR $(95 \%)=0.24$
SA $(5 \%)=0.06$ SA $=0.09$ SA $(95 \%)=0.22$
SB $(5 \%)=0.07$ SB $=0.11$ SB $(95 \%)=0.26$

\begin{tabular}{|c|c|c|c|c|c|}
\hline $\begin{array}{l}\text { LA.B } \\
\text { CODE } \\
\text { D6 } \\
D 6 \\
D 6 \\
D 6 \\
D 6\end{array}$ & $\begin{array}{c}\text { PHANTOM } \\
\text { TYPE } \\
\text { M2-MN54 } \\
\text { M2-MN54 } \\
\text { M2-MN54 } \\
\text { M2-MN55 } \\
\text { M2-MN54 }\end{array}$ & $\begin{array}{c}\text { COUNT } \\
\text { NO. } \\
1 \\
2 \\
3 \\
4 \\
5\end{array}$ & $\begin{array}{c}\text { DATE } \\
\text { COUNTED } \\
10=12-87 \\
10=12=87 \\
10-12=87 \\
10-12-87 \\
10=12=87\end{array}$ & $\begin{array}{c}\text { LAB ASSAY } \\
(n C i) \\
124.10 \\
129.40 \\
130.10 \\
127.70 \\
120.20\end{array}$ & $\begin{array}{l}\text { ERROR(\%) } \\
4.00 \\
3.90 \\
3.80 \\
3.90 \\
4.20\end{array}$ \\
\hline
\end{tabular}

MEAN $=126.3 \quad$ Lab Est. Rel. Error $=0.04$
BR $(5 \%)=4.34$ BR $=4.51$ BR $(95 \%)=4.68$
SA $(5 \%)=0.02$ SA $=0.03$ SA $(95 \%)=0.08$
SB (5\%) $=0.12$ SB $=0.18$ SB $(95 \%)=0.43$




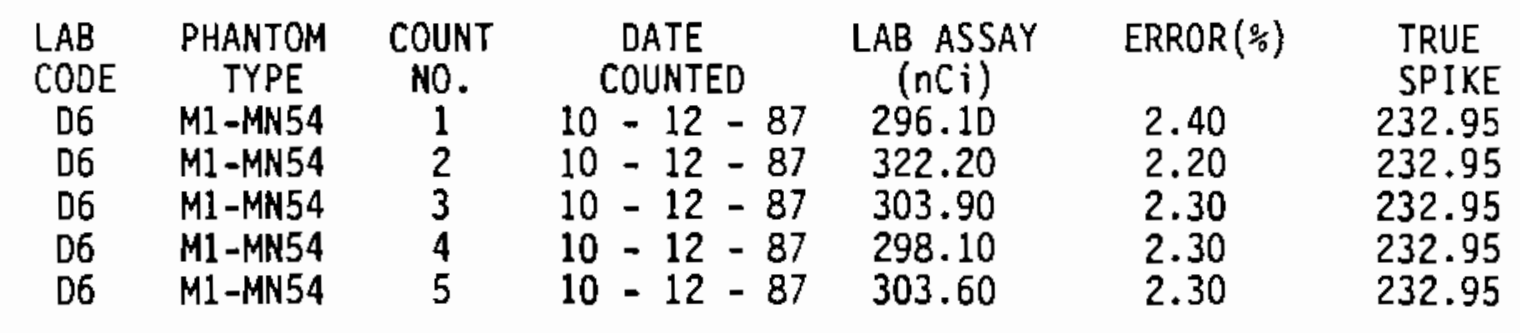

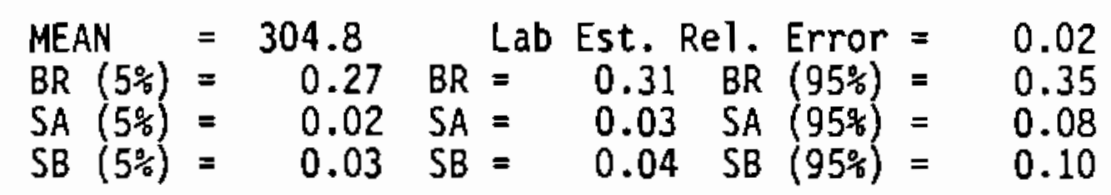

\begin{tabular}{|c|c|c|c|c|c|c|c|}
\hline $\begin{array}{l}\text { LAB } \\
\text { CODE } \\
\text { D6 } \\
\text { D6 } \\
\text { D6 } \\
\text { D6 } \\
\text { D6 }\end{array}$ & $\begin{array}{l}\text { PHANTOM } \\
\text { TYPE } \\
\text { M1-CE144 } \\
\text { M1-CE144 } \\
\text { M1-CE144 } \\
\text { M1-CE144 } \\
\text { M1-CE144 }\end{array}$ & $\begin{array}{c}\text { COUNT } \\
\text { NO. } \\
1 \\
2 \\
3 \\
4 \\
5\end{array}$ & $\begin{array}{c}\text { DATE } \\
\text { COUNTEL } \\
10=12 \\
10-12 \\
10=12 \\
10-12- \\
10=12\end{array}$ & $\begin{array}{l}\text { D } \\
-87 \\
-87 \\
-87 \\
-87 \\
-87\end{array}$ & $\begin{array}{c}\text { LAB ASSAY } \\
(\mathrm{nCi}) \\
826.70 \\
773.30 \\
823.30 \\
794.20 \\
680.00\end{array}$ & $\begin{array}{l}6.40 \\
6.50 \\
6.40 \\
5.20 \\
7.90\end{array}$ & $\begin{array}{c}\text { TRUE } \\
\text { SPIKE } \\
609.49 \\
609.49 \\
609.49 \\
609.49 \\
609.49\end{array}$ \\
\hline
\end{tabular}

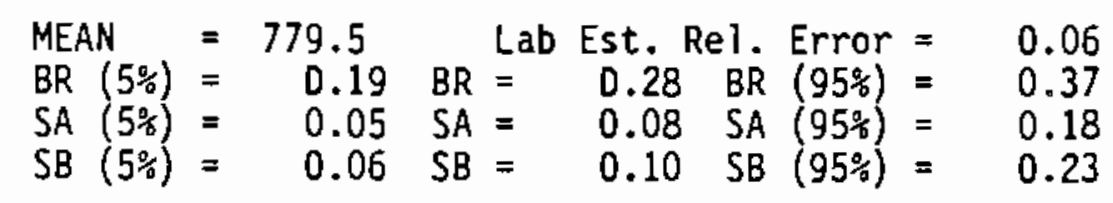

$\begin{array}{ccccccc}\text { LAB } & \text { PHANTOM } & \text { COUNT } & \text { DATE } & \text { LAB ASSAY } & \text { ERROR }(\%) & \text { TRUE } \\ \text { CODE } & \text { TYPE } & \text { NO. } & \text { COUNTE0 } & \text { (nCi) } & & \text { SPIKE } \\ \text { G } & \text { W1-CS134 } & 1 & 10-9-87 & 147.00 & 5.00 & 197.45 \\ \text { G } & \text { W1-CS134 } & 2 & 10-9-87 & 141.00 & 5.00 & 197.45 \\ \text { G } & \text { W1-CS134 } & 3 & 10-9-87 & 144.00 & 5.00 & 197.45 \\ \text { G } & \text { W1-CS134 } & 4 & 10-9-87 & 140.00 & 5.00 & 197.45 \\ \text { G } & \text { W1-CS134 } & 5 & 10-9-87 & 144.00 & 5.00 & 197.45\end{array}$

\begin{tabular}{|c|c|c|c|c|c|c|c|c|}
\hline $\begin{array}{l}\text { MEAN } \\
\text { BR }(5 \%) \\
\text { SA }(5 \%) \\
\text { SB }(5 \%)\end{array}$ & $\begin{array}{l}= \\
= \\
= \\
=\end{array}$ & $\begin{array}{r}143.2 \\
-0.29 \\
0.01 \\
0.01\end{array}$ & $\begin{array}{l}\text { BR } \\
\text { SA } \\
S B\end{array}$ & $\begin{array}{l}\text { Lab } \\
= \\
= \\
=\end{array}$ & $\begin{array}{l}\text { Est. } \\
-0.27 \\
0.02 \\
0.01\end{array}$ & $\begin{array}{r}\mathrm{Re} \mathrm{T}_{\mathrm{BR}} \\
\mathrm{SA} \\
\mathrm{SB}\end{array}$ & $\begin{array}{l}\text { Error } \\
(95 \%) \\
(95 \%) \\
(95 \%)\end{array}$ & \\
\hline
\end{tabular}

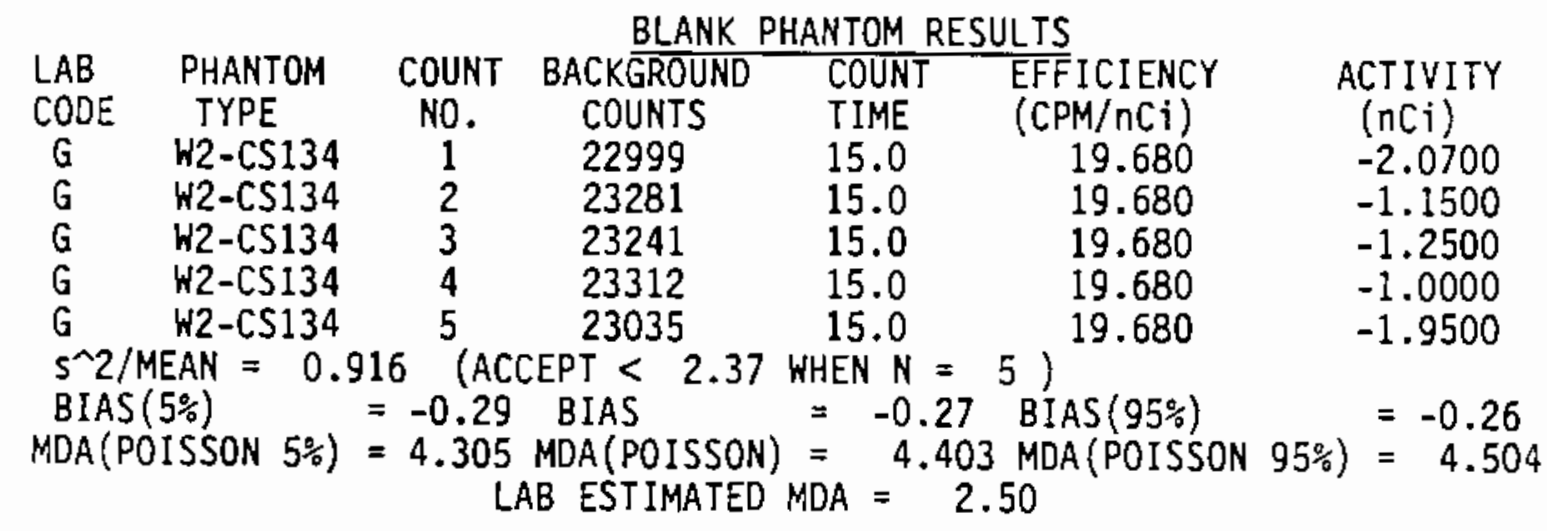




\begin{tabular}{ccccccc} 
LAB & PHANTOM & COUNT & DATE & LAB ASSAY & ERROR $(\%)$ & \multicolumn{1}{c}{ TRUE } \\
CODE & TYPE & NO. & COUNTED & $(\mathrm{nCi})$ & & SPIKE \\
G & W1-CS137 & 1 & $10-9-87$ & 348.00 & 5.00 & 350.67 \\
G & W1-CS137 & 2 & $10-9-87$ & 343.00 & 5.00 & 350.67 \\
G & W1-CS137 & 3 & $10-9-87$ & 355.00 & 5.00 & 350.67 \\
$G$ & $W 1-C S 137$ & 4 & $10-9-87$ & 352.00 & 5.00 & 350.67 \\
$G$ & W1-CS137 & 5 & $10-9-87$ & 347.00 & 5.00 & 350.67
\end{tabular}

$\begin{array}{lllll}\text { MEAN } & =349.0 & \text { Lab Est. Rel. Error }= & 0.05 \\ \mathrm{BR}(5 \%) & =-0.02 & \mathrm{BR}= & =0.00 \mathrm{BR}(95 \%)= & 0.01 \\ \mathrm{SA}(5 \%) & =0.01 \mathrm{SA}=0.01 \mathrm{SA}(95 \%)= & 0.03 \\ \mathrm{SB}(5 \%)= & 0.01 \mathrm{SB}=0.01 \mathrm{SB}(95 \%)= & 0.03\end{array}$

\begin{tabular}{|c|c|c|c|c|c|c|}
\hline $\begin{array}{l}\text { LAB } \\
\text { CODE } \\
\text { GI } \\
\text { G1 } \\
\text { G1 } \\
\text { GI } \\
\text { G1 }\end{array}$ & $\begin{array}{l}\text { PHANTOM } \\
\text { TYPE } \\
\text { W1-CS137 } \\
W 1-C S 137 \\
W 1-C S 137 \\
W 1-C S 137 \\
W 1-C S 137\end{array}$ & $\begin{array}{c}\text { COUNT } \\
\text { NO. } \\
1 \\
2 \\
3 \\
4 \\
5\end{array}$ & $\begin{array}{c}\text { DATE } \\
\text { COUNTED } \\
10-9-87 \\
10-9-87 \\
10-9=87 \\
10-9-87 \\
10-9-87\end{array}$ & $\begin{array}{c}\text { LAB ASSAY } \\
(\mathrm{nC} \mathrm{i}) \\
338.0 \\
335.0 \\
337.0 \\
339.0 \\
335.0\end{array}$ & $\begin{array}{l}1.8 \\
1.8 \\
1.8 \\
1.8 \\
1.8\end{array}$ & $\begin{array}{c}\text { TRUE } \\
\text { SPIKE } \\
350.67 \\
350.67 \\
350.67 \\
350\end{array}$ \\
\hline
\end{tabular}

MEAN $=336.8 \quad$ Lab. Est. Rel. Error $=0.02$

No Data $S A=0.01 \quad$ No Data

$S B=0.01$

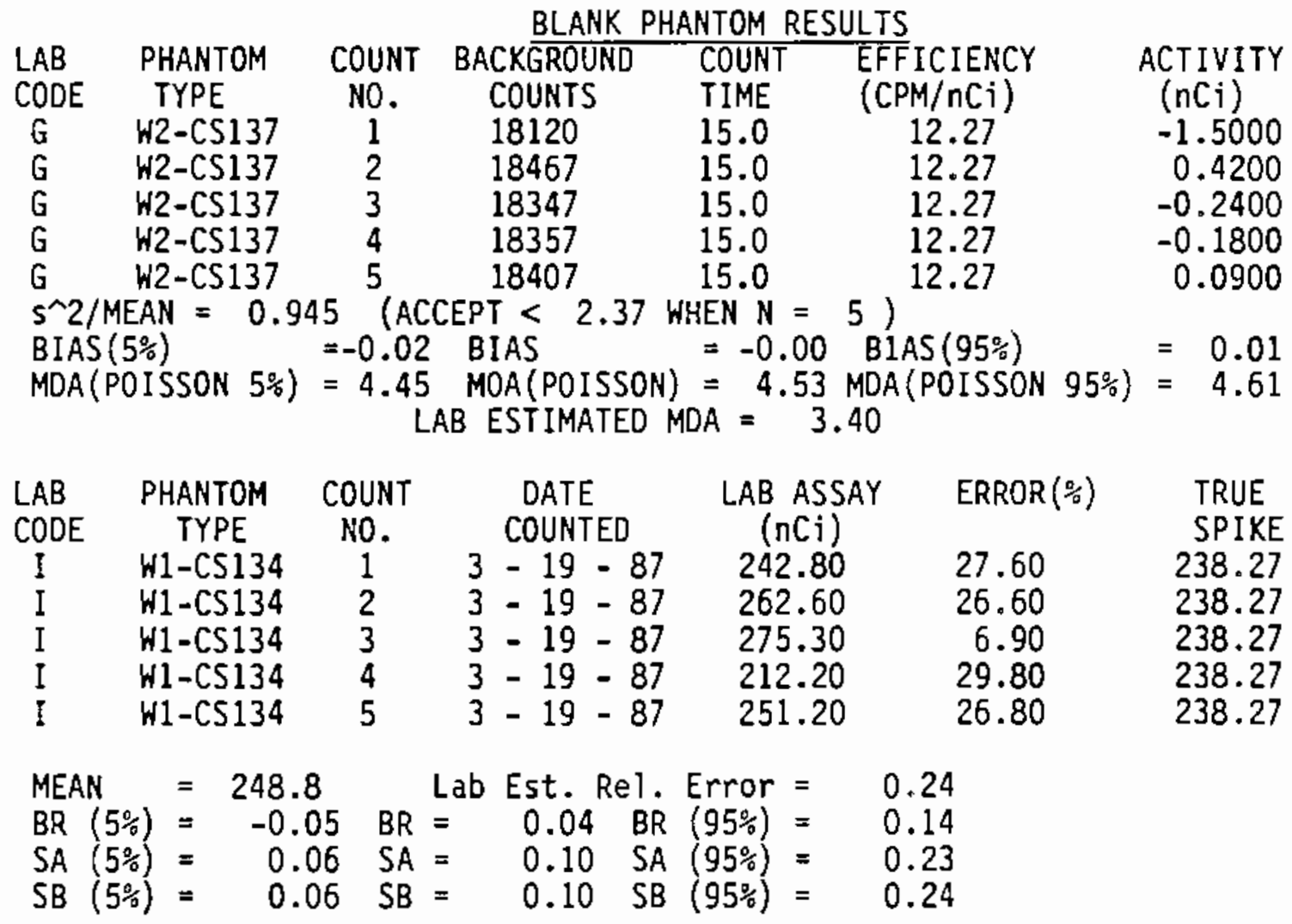




\begin{tabular}{|c|c|c|c|c|c|c|}
\hline $\begin{array}{l}\mathrm{LAB} \\
\mathrm{COOE} \\
\mathrm{I} \\
\mathrm{I} \\
\mathrm{I} \\
\mathrm{I} \\
\mathrm{I}\end{array}$ & $\begin{array}{l}\text { PHANTOM } \\
\text { TYPE } \\
W 1-C S 137 \\
W 1-C S 137 \\
W 1-C S 137 \\
W 1-C S 137 \\
W 1-C S 137\end{array}$ & $\begin{array}{c}\text { COUNT } \\
\text { NO. } \\
1 \\
2 \\
3 \\
4 \\
5\end{array}$ & $\begin{array}{c}\text { DATE } \\
\text { COUNTED } \\
3-19-87 \\
3-19-87 \\
3-19-87 \\
3-19-87 \\
3-19-87\end{array}$ & $\begin{array}{c}\text { LAB ASSAY } \\
\text { (nCi) } \\
450.20 \\
450.10 \\
509.00 \\
405.00 \\
456.90\end{array}$ & $\begin{array}{l}8.70 \\
9.10 \\
8.20 \\
9.90 \\
9.80\end{array}$ & $\begin{array}{c}\text { TRUE } \\
\text { SPIKE } \\
355.20 \\
355.20 \\
355.20 \\
355.20 \\
355.20\end{array}$ \\
\hline
\end{tabular}

MEAN $=454.2 \quad$ Lab Est. Rel. Error $=0.09$
BR $(5 \%)=0.18$ BR $=0.28$ BR $(95 \%)=0.38$
SA $(5 \%)=0.05$ SA $=0.08$ SA $(95 \%)=0.19$
SB $(5 \%)=0.07$ SB $=0.10$ SB $(95 \%)=0.25$

$\begin{array}{lcccccc}\text { LAB } & \text { PHANTOM } & \text { COUNT } & \text { OATE } & \text { LAB ASSAY } & \text { ERROR }(\%) & \text { TRUE } \\ \text { COOE } & \text { TYPE } & \text { NO. } & \text { COUNTED } & (n C i) & & \text { SPIKE } \\ \text { I } & \text { M2-CE144 } & 1 & 7-14-87 & 524.90 & 39.80 & 87.99 \\ \text { I } & \text { M2-CE144 } & 2 & 7-14-87 & 355.00 & 33.20 & 87.99 \\ \text { I } & \text { M2-CE144 } & 3 & 7-14-87 & 487.70 & 22.70 & 87.99 \\ \text { I } & \text { M2-CE144 } & 4 & 7-14-87 & 387.10 & 28.60 & 87.99 \\ \text { I } & \text { M2-CE144 } & 5 & 7-14-87 & 526.30 & 25.60 & 87.99\end{array}$

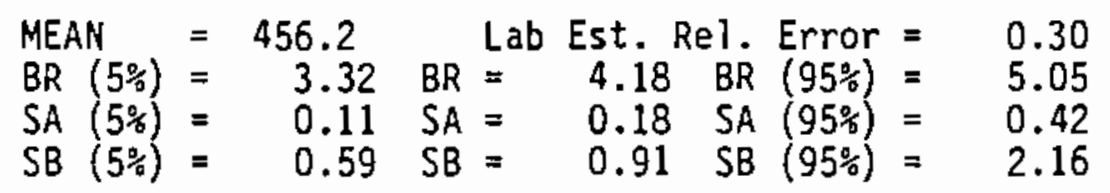

\begin{tabular}{llccccr} 
LAB & PHANTOM & COUNT & OATE & LAB ASSAY & ERROR(\%) & \multicolumn{1}{c}{ TRUE } \\
COOE & TYPE & NO. & COUNTED & (nCi) & & SPIKE \\
I & M1-CE144 & 1 & $7-15-87$ & 2731.00 & 5.50 & 757.18 \\
I & M1-CE144 & 2 & $7-15-87$ & 2713.00 & 5.50 & 757.18 \\
I & M1-CE144 & 3 & $7-15-87$ & 2698.00 & 5.50 & 757.18 \\
I & M1-CE144 & 4 & $7-15-87$ & 2765.00 & 5.50 & 757.18 \\
I & M1-CE144 & 5 & $7-15-87$ & 2751.00 & 5.50 & 757.18
\end{tabular}

\begin{tabular}{|c|c|c|c|c|c|c|}
\hline $\begin{array}{l}\text { MEAN } \\
\text { BR } \quad(5 \%) \\
\text { SA } \quad(5 \%) \\
\text { SB }(5 \%)\end{array}$ & $\begin{array}{lr}= & 2731.6 \\
= & 2.57 \\
= & 0.01 \\
= & 0.02\end{array}$ & $\begin{array}{l}\text { BR } \\
\text { SA } \\
\text { SB }\end{array}$ & $\begin{array}{l}\text { Lab } \\
= \\
= \\
=\end{array}$ & $\begin{array}{cc}\text { Est. } & \text { Rel. } \\
2.61 & \text { BR } \\
0.01 & \text { SA } \\
0.04 & \text { SB }\end{array}$ & $\begin{array}{l}\text { Error } \\
(95 \%) \\
(95 \%) \\
(95 \%)\end{array}$ & \\
\hline
\end{tabular}

$\begin{array}{llccccc}\text { LAB } & \text { PHANTOM } & \text { COUNT } & \text { DATE } & \text { LAB ASSAY } & \text { ERROR }(\%) & \text { TRUE } \\ \text { CODE } & \text { TYPE } & \text { NO. } & \text { COUNTED } & (\mathrm{nC} \text { i }) & & \text { SPIKE } \\ \text { I } & \text { M2-MN54 } & 1 & 7-15-87 & 42.00 & 11.00 & 27.94 \\ \text { I } & \text { M2-MN54 } & 2 & 7-15-87 & 50.25 & 21.00 & 27.94\end{array}$

$\begin{array}{llll}\text { MEAN } & =46.1 & \text { Lab Est. Re 1. Error }= & 0.16 \\ \text { BR }(5 \%)= & -0.28 \text { BR }=0.65 \text { BR }(95 \%)=1.58 \\ \text { SA }(5 \%)=0.06 \text { SA }=0.13 \text { SA }(95 \%)= & 2.01 \\ \text { SB }(5 \%)=0.11 \text { SB }=0.21 \text { SB }(95 \%)=3.31\end{array}$




\begin{tabular}{|c|c|c|c|c|c|c|c|c|}
\hline \multicolumn{2}{|r|}{$\begin{array}{l}P \\
M \\
M \\
M \\
M \\
M\end{array}$} & $\begin{array}{l}\text { PHANTOM } \\
\text { TYPE } \\
\text { M1-MN54 } \\
\text { M1-MN54 } \\
\text { M1-MN54 } \\
\text { M1-MN54 } \\
\text { M1-MN54 }\end{array}$ & $\begin{array}{l}\text { COUNT } \\
\text { NO. } \\
1 \\
2 \\
3 \\
4 \\
5\end{array}$ & \multicolumn{2}{|c|}{$\begin{array}{c}\text { DATE } \\
\text { COUNTED } \\
7=15-87 \\
7=15=87 \\
7-15-87 \\
7=15-87 \\
7-15-87\end{array}$} & \multicolumn{3}{|c|}{$\begin{array}{c}\text { LAB ASSAY } \\
\text { (nCi) } \\
456.70 \\
456.90 \\
451.80 \\
455.70 \\
444.20\end{array}$} \\
\hline $\begin{array}{l}\text { MEAN } \\
\text { BR } \quad(5 \% \\
\text { SA } \quad(5 \% \\
\text { SB } \quad(5 \%\end{array}$ & & $\begin{array}{c}453.1 \\
0.58 \\
0.01 \\
0.01\end{array}$ & $\begin{array}{l}\text { BR } \\
\text { SA } \\
\text { SB }\end{array}$ & $\begin{array}{l}\text { Lab } \\
= \\
= \\
=\end{array}$ & $\begin{array}{cc}\text { Est. } & \text { Rel. } \\
0.60 & \text { BR } \\
0.01 & \text { SA } \\
0.02 & \text { SB }\end{array}$ & $\begin{array}{l}\text { Error }= \\
(95 \%)= \\
(95 \%)= \\
(95 \%)=\end{array}$ & $\begin{array}{l}= \\
= \\
= \\
=\end{array}$ & $\begin{array}{l}0.0 \\
0.6 \\
0.0 \\
0.0\end{array}$ \\
\hline
\end{tabular}

\begin{tabular}{|c|c|c|c|c|c|c|}
\hline $\begin{array}{l}\text { LAB } \\
\text { CODE } \\
\text { J1 } \\
\text { J1 } \\
\text { J1 } \\
\text { J1 } \\
\text { J1 }\end{array}$ & $\begin{array}{l}\text { PHANTOM } \\
\text { TYPE } \\
\text { M2-CE144 } \\
\text { M2-CE144 } \\
\text { M2-CE144 } \\
\text { M2-CE144 } \\
\text { M2-CE144 }\end{array}$ & $\begin{array}{c}\text { COUNT } \\
\text { NO. } \\
1 \\
2 \\
3 \\
4 \\
5\end{array}$ & $\begin{array}{c}\text { DATE } \\
\text { COUNTED } \\
\begin{array}{c}2-1=87 \\
2-1=87 \\
2-1=87 \\
2-1-87 \\
2-1-87\end{array}\end{array}$ & $\begin{array}{c}\text { LAB ASSAY } \\
(\mathrm{nCi}) \\
2095.00 \\
2164.00 \\
1910.00 \\
1616.00 \\
1836.00\end{array}$ & $\begin{array}{l}5.70 \\
5.70 \\
6.40 \\
6.70 \\
5.90\end{array}$ & $\begin{array}{l}\text { TRUE } \\
\text { SPIKE } \\
680.29 \\
680.29 \\
680.29 \\
680.29 \\
680.29\end{array}$ \\
\hline
\end{tabular}

$\begin{array}{llll}\text { MEAN } & =1924.2 & \text { Lab Est. Rel. Error }= & 0.06 \\ \mathrm{BR}(5 \%)= & 1.52 \mathrm{BR}= & 1.83 \mathrm{BR}(95 \%)= & 2.13 \\ \mathrm{SA}(5 \%)= & 0.07 \mathrm{SA}= & 0.11 \mathrm{SA}(95 \%)= & 0.27 \\ \mathrm{SB}(5 \%)= & 0.21 \mathrm{SB}= & 0.32 \mathrm{SB}(95 \%)= & 0.76\end{array}$

\begin{tabular}{|c|c|c|c|c|c|c|}
\hline $\begin{array}{l}\text { LAB } \\
\text { CODE } \\
\mathrm{J1} \\
\mathrm{J} 1 \\
\mathrm{~J} 1 \\
\mathrm{~J} 1 \\
\mathrm{~J} 1\end{array}$ & $\begin{array}{l}\text { PHANTOM } \\
\text { TYPE } \\
\text { M1-CE144 } \\
M 1-C E 144 \\
\text { M1-CE144 } \\
\text { M1-CE144 } \\
\text { M1-CE144 }\end{array}$ & $\begin{array}{c}\text { COUNT } \\
\text { NO. } \\
1 \\
2 \\
3 \\
4 \\
5\end{array}$ & $\begin{array}{c}\text { DATE } \\
\text { COUNTED } \\
2-1=87 \\
2-1-87 \\
2-1-87 \\
2-1-87 \\
2-1-87\end{array}$ & $\begin{array}{c}\text { LAB ASSAY } \\
(\mathrm{nCj}) \\
1108.00 \\
885.00 \\
1040.00 \\
1023.00 \\
1032.00\end{array}$ & $\begin{array}{r}10.00 \\
11.40 \\
9.70 \\
10.50 \\
9.70\end{array}$ & $\begin{array}{l}\text { TRUE } \\
\text { SPIKE } \\
580.03 \\
580.03 \\
580.03 \\
580.03 \\
580.03\end{array}$ \\
\hline
\end{tabular}

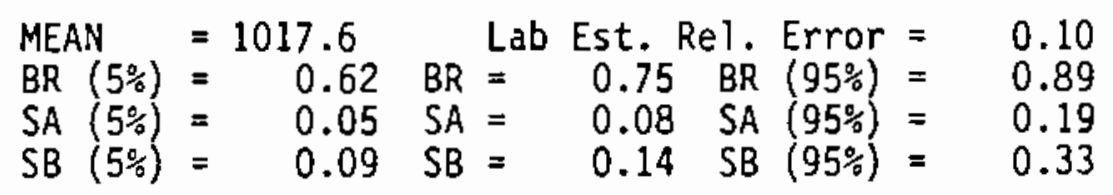

BLANK PHANTOM RESULTS

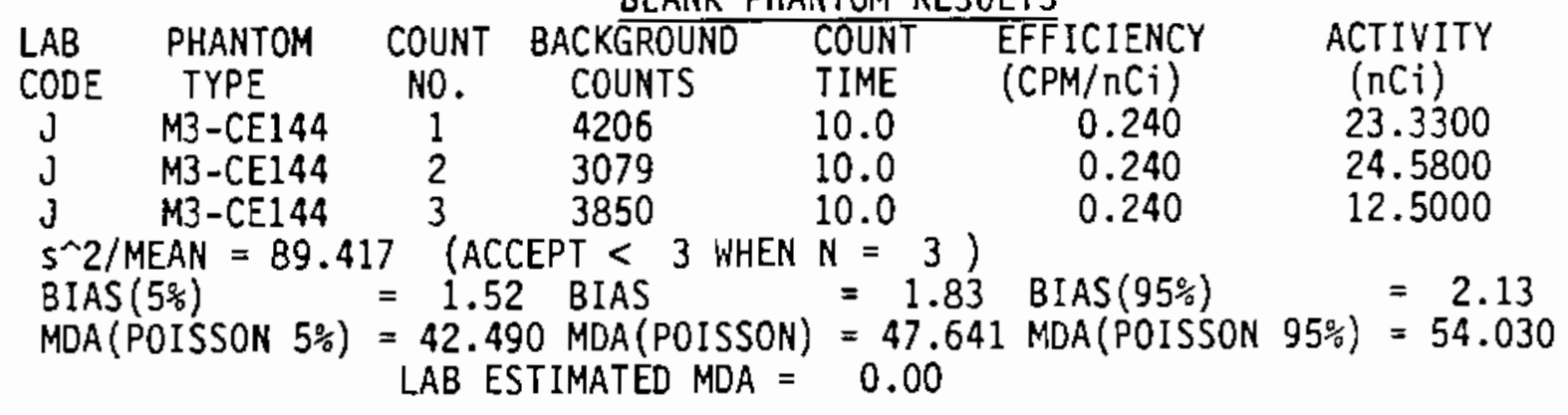




$\begin{array}{ccccccc}\text { LAB } & \text { PHANTOM } & \text { COUNT } & \text { DATE } & \text { LAB ASSAY } & \text { ERROR }(\%) & \text { TRUE } \\ \text { COOE } & \text { TYPE } & \text { NO. } & \text { COUNTEO } & \text { (nCi) } & & \text { SPIKE } \\ \text { J1 } & \text { M2-MN54 } & 1 & 2-1-87 & 512.00 & 2.30 & 246.09 \\ \text { J1 } & \text { M2-MN54 } & 2 & 2-1-87 & 424.00 & 2.50 & 246.09 \\ \text { J1 } & \text { M2-MN54 } & 3 & 2-1-87 & 400.00 & 2.00 & 246.09\end{array}$

MEAN $=445.3 \quad$ Lab Est. Rel. Error $=0.02$
BR $(5 \%)=0.41$ BR $=0.81$ BR $(95 \%)=1.21$
SA $(5 \%)=0.08$ SA $=0.13$ SA $(95 \%)=0.58$
SB $(5 \%)=0.14$ SB $=0.24$ SB $(95 \%)=1.06$

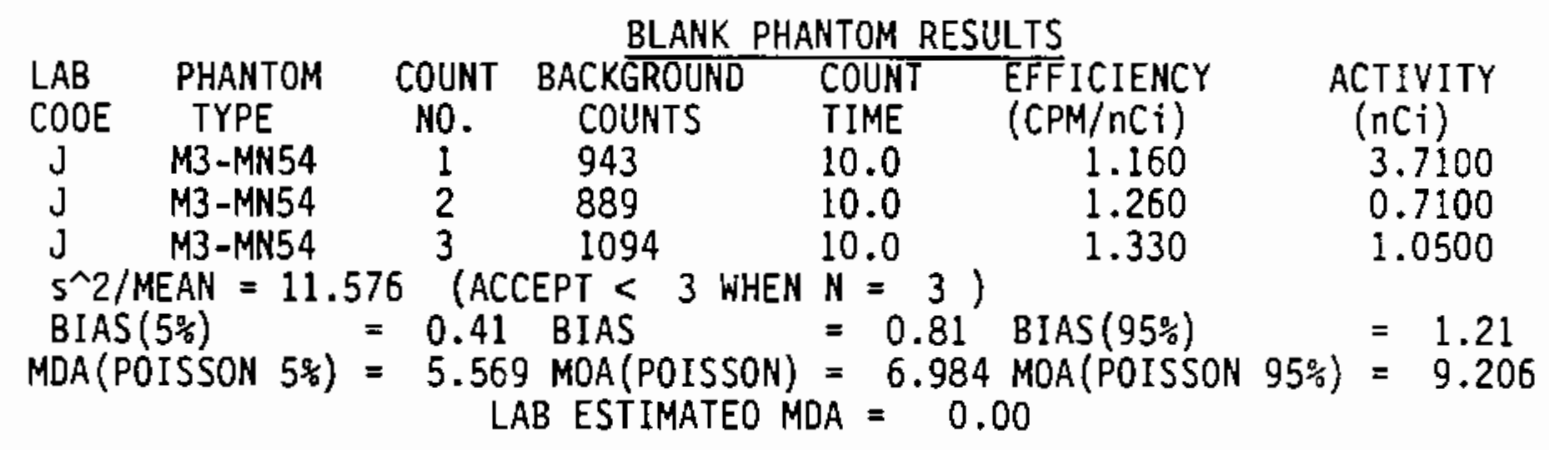

$\begin{array}{llccccc}\text { LAB } & \text { PHANTOM } & \text { COUNT } & \text { OATE } & \text { LAB ASSAY } & \text { ERROR }(\%) & \text { TRUE } \\ \text { COOE } & \begin{array}{c}\text { TYPE } \\ \text { J2 }\end{array} & \text { NO. } & \text { COUNTED } & \text { (nCi) } & & \text { SPIKE } \\ \text { J2 } & \text { M2-MN54 } & 1 & 2-1-87 & 944.00 & 1.50 & 246.09 \\ \text { J2 } & \text { M2-MN54 } & 2 & 2-1-87 & 942.00 & 2.20 & 246.09 \\ \text { J2 } & \text { M2-MN54 } & 4 & 2-1-87 & 788.00 & 1.70 & 246.09 \\ \text { J2 } & \text { M2-MN54 } & 5 & 2-1-87 & 793.00 & 2.60 & 246.09 \\ & \text { M2-MN5 } & & & 770.00 & 1.70 & 246.09\end{array}$

MEAN $=847.4 \quad$ Lab Est. Rel. Error $=0.02$
BR $(5 \%)=2.10 \mathrm{BR}=2.44 \mathrm{BR}(95 \%)=2.78$
SA $(5 \%)=0.07 \mathrm{SA}=0.10 \mathrm{SA}(95 \%)=0.25$
SB $(5 \%)=0.23 \mathrm{SB}=0.36 \mathrm{SB}(95 \%)=0.84$

$\begin{array}{ccccccc}\text { LAB } & \text { PHANTOM } & \text { COUNT } & \text { OATE } & \text { LAB ASSAY } & \text { ERROR }(\%) & \text { TRUE } \\ \text { CODE } & \text { TYPE } & \text { NO. } & \text { COUNTED } & \text { (nCi) } & & \text { SPIKE } \\ \text { J2 } & \text { M1-MN54 } & 1 & 2-1-87 & 628.00 & 1.80 & 202.03 \\ \text { J2 } & \text { M1-MN54 } & 2 & 2-1-87 & 593.00 & 2.00 & 202.03 \\ \text { J2 } & \text { M1-MN54 } & 3 & 2-1-87 & 540.00 & 2.80 & 202.03 \\ \text { J2 } & \text { M1-MN54 } & 4 & 2-1-87 & 517.00 & 2.10 & 202.03\end{array}$

MEAN $=569.5 \quad$ Lab Est. Rel. Error $=0.02$
BR $(5 \%)=1.53 \mathrm{BR}=1.82 \mathrm{BR}(95 \%)=2.11$
SA $(5 \%)=0.05 \mathrm{SA}=0.09 \mathrm{SA}(95 \%)=0.26$
SB $(5 \%)=0.15 \mathrm{SB}=0.25 \mathrm{SB}(95 \%)=0.73$




$\begin{array}{llccccc}\text { LAB } & \text { PHANTOM } & \text { COUNT } & \text { DATE } & \text { LAB ASSAY } & \text { ERROR(\%) } & \text { TRUE } \\ \text { CODE } & \text { TYPE } & \text { NO. } & \text { COUNTE0 } & (n C j) & & \text { SPIKE } \\ \text { J2 } & \text { M2-CE144 } & 1 & 2-1-87 & 2341.00 & 5.30 & 680.29 \\ \text { J2 } & \text { M2-CE144 } & 2 & 2-1-87 & 2375.00 & 5.30 & 680.29 \\ \text { J2 } & \text { M2-CE144 } & 3 & 2-1-87 & 1898.00 & 5.30 & 680.29 \\ \text { J2 } & \text { M2-CE144 } & 4 & 2-1-87 & 1909.00 & 6.10 & 680.29 \\ \text { J2 } & \text { M2-CE144 } & 5 & 2-1-87 & 1880.00 & 6.20 & 680.29\end{array}$

$\begin{array}{lllll}\operatorname{MEAN} & =2080.6 \quad \text { Lab Est. Rel. Error }= & 0.06 \\ \mathrm{BR}(5 \%) & =1.70 \mathrm{BR}= & 2.06 \mathrm{BR}(95 \%)= & 2.41 \\ \mathrm{SA}(5 \%) & =0.08 \mathrm{SA}= & 0.12 \mathrm{SA}(95 \%)= & 0.29 \\ \mathrm{SB}(5 \%) & =0.24 \mathrm{SB}= & 0.37 \mathrm{SB}(95 \%)= & 0.88\end{array}$

$\begin{array}{llccccc}\text { LAB } & \text { PHANTOM } & \text { COUNT } & \text { DATE } & \text { LAB ASSAY } & \text { ERROR }(\%) & \text { TRUE } \\ \text { CODE } & \text { TYPE } & \text { NO. } & \text { COUNTED } & (\mathrm{nCi}) & & \text { SPIKE } \\ \mathrm{J} 2 & \text { M1-CE144 } & 1 & 2-1-87 & 1093.00 & 10.60 & 580.03 \\ \mathrm{~J} 2 & \text { M1-CE144 } & 2 & 2-1-87 & 811.00 & 11.20 & 580.03 \\ \mathrm{~J} 2 & \text { M1-CE144 } & 3 & 2-1-87 & 938.00 & 11.90 & 580.03 \\ \mathrm{~J} 2 & \text { M1-CE144 } & 4 & 2-1-87 & 1009.00 & 10.90 & 580.03 \\ \mathrm{~J} 2 & \text { M1-CE144 } & 5 & 2-1-87 & 892.00 & 11.50 & 580.03\end{array}$

\begin{tabular}{|c|c|c|c|c|c|c|c|c|}
\hline $\begin{array}{l}\text { MEAN } \\
\text { BR } \quad(5 \%) \\
\text { SA } \quad(5 \%) \\
\text { SB } \quad(5 \%)\end{array}$ & $\begin{array}{l}= \\
= \\
= \\
=\end{array}$ & $\begin{array}{r}948.6 \\
0.46 \\
0.07 \\
0.12\end{array}$ & $\begin{array}{l}\text { BR } \\
\text { SA } \\
\text { SB }\end{array}$ & $\begin{array}{l}\text { Lab } \\
= \\
= \\
=\end{array}$ & $\begin{array}{c}\text { Est. } \\
0.64 \\
0.11 \\
0.19\end{array}$ & $\begin{array}{r}\text { Rel. } \\
\text { BR } \\
\text { SA } \\
\text { SB }\end{array}$ & $\begin{array}{l}\text { Error } \\
(95 \%) \\
(95 \%) \\
(95 \%)\end{array}$ & \\
\hline
\end{tabular}

\begin{tabular}{lcccccr} 
LAB & PHANTOM & COUNT & DATE & LAB ASSAY & ERROR $\%)$ & \multicolumn{1}{c}{ TRUE } \\
CODE & TYPE & NO. & COUNTED & (nCi) & & SPIKE \\
J3 & M2-MN54 & 1 & $2-1-87$ & 850.00 & 1.60 & 246.09 \\
J3 & M2-MN54 & 2 & $2-1-87$ & 561.00 & 1.60 & 246.09 \\
J3 & M2-MN54 & 3 & $2-1-87$ & 806.00 & 1.60 & 246.09 \\
J3 & M2-MN54 & 4 & $2-1-87$ & 804.00 & 1.60 & 246.09 \\
J3 & M2-MN54 & 5 & $2-1-87$ & 504.00 & 1.70 & 246.09
\end{tabular}

$\begin{array}{llllll}\operatorname{MEAN} & =705.0 & \text { Lab Est. Rel. Error }= & 0.02 \\ \mathrm{BR}(5 \%) & =1.25 \mathrm{BR}= & 1.86 \mathrm{BR}(95 \%)= & 2.48 \\ \mathrm{SA}(5 \%) & =0.15 \mathrm{SA}= & 0.23 \mathrm{SA}(95 \%)= & 0.54 \\ \mathrm{SB}(5 \%)= & 0.42 \mathrm{SB}= & 0.65 \mathrm{SB}(95 \%)= & 1.54\end{array}$

$\begin{array}{lcccccc}\text { LAB } & \text { PHANTOM } & \text { COUNT } & \text { OATE } & \text { LAB ASSAY } & \text { ERROR }(\%) & \text { TRUE } \\ \text { CODE } & \text { TYPE } & \text { NO. } & \text { COUNTED } & (\mathrm{nCi}) & & \text { SPIKE } \\ \text { J3 } & \text { M1-MN54 } & 1 & 2-1-87 & 628.00 & 1.80 & 202.03 \\ \text { J3 } & \text { M1-MN54 } & 2 & 2-1-87 & 593.00 & 2.00 & 202.03 \\ \text { J3 } & \text { M1-MN54 } & 3 & 2-1-87 & 540.00 & 2.80 & 202.03 \\ \text { J3 } & \text { M1-MN54 } & 4 & 2-1-87 & 517.00 & 2.10 & 202.03\end{array}$

$\begin{array}{lllll}\operatorname{MEAN} & =569.5 & \text { Lab Est. Rel. Error }= & 0.02 \\ \mathrm{BR}(5 \%) & =1.53 \mathrm{BR}= & 1.82 \mathrm{BR}(95 \%)= & 2.11 \\ \text { SA }(5 \%)= & 0.05 \mathrm{SA}= & 0.09 \mathrm{SA}(95 \%)= & 0.26 \\ \mathrm{SB}(5 \%)= & 0.15 \mathrm{SB}= & 0.25 \mathrm{SB}(95 \%)= & 0.73\end{array}$




\begin{tabular}{lcccccc} 
LAB & PHANTOM & COUNT & DATE & LA8 ASSAY & ERROR $(\%)$ & \multicolumn{1}{c}{ TRUE } \\
CODE & TYPE & NO. & COUNTED & (nCi) & & SPIKE \\
J3 & M2-CE144 & 1 & $2-1-87$ & 2058.00 & 5.70 & 680.29 \\
J3 & M2-CE144 & 2 & $2-1-87$ & 1806.00 & 5.60 & 680.29 \\
J3 & M2-CE144 & 3 & $2-1-87$ & 1841.00 & 5.90 & 680.29 \\
J3 & M2-CE144 & 4 & $2-1-87$ & 1654.00 & 5.30 & 680.29 \\
J3 & M2-CE144 & 5 & $2-1-87$ & 1640.00 & 5.60 & 680.29
\end{tabular}

$$
\begin{aligned}
& \text { MEAN }=1799.8 \quad \text { Lab Est. Rel. Error }=0.06 \\
& B R(5 \%)=1.41 \quad B R=1.65 \quad B R(95 \%)=1.88 \\
& S A(5 \%)=0.06 \mathrm{SA}=0.09 \mathrm{SA}(95 \%)=0.22 \\
& \mathrm{SB}(5 \%)=0.16 \mathrm{SB}=0.25 \mathrm{SB}(95 \%)=0.59
\end{aligned}
$$

$\begin{array}{ccccccc}\text { LAB } & \text { PHANTOM } & \text { COUNT } & \text { DATE } & \text { LAB ASSAY } & \text { ERROR }(\%) & \text { TRUE } \\ \text { COOE } & \text { TYPE } & \text { NO. } & \text { COUNTED } & (n C i) & & \text { SPIKE } \\ \text { J3 } & \text { M1-CE144 } & 1 & 2-1-87 & 852.00 & 9.80 & 580.03 \\ \text { J3 } & \text { M1-CE144 } & 2 & 2-1-87 & 1041.00 & 9.30 & 580.03 \\ \text { J3 } & \text { M1-CE144 } & 3 & 2-1-87 & 869.00 & 9.30 & 580.03 \\ \text { J3 } & \text { M1-CE144 } & 4 & 2-1-87 & 901.00 & 9.80 & 580.03 \\ \text { J3 } & \text { M1-CE144 } & 5 & 2-1-87 & 744.00 & 11.20 & 580.03\end{array}$

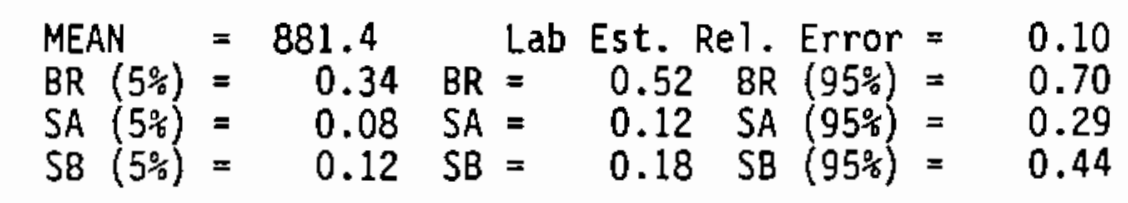

$\begin{array}{llccccc}\text { LAB } & \text { PHANTOM } & \text { COUNT } & \text { DATE } & \text { LAB ASSAY } & \text { ERROR(\%) } & \text { TRUE } \\ \text { COOE } & \text { TYPE } & \text { NO. } & \text { COUNTED } & \text { (nCi) } & & \text { SPIKE } \\ \text { J3 } & \text { W1-CS134 } & 1 & 10-23-86 & 206.00 & 6.70 & 272.81 \\ \text { J3 } & \text { W1-CS134 } & 2 & 10-23-86 & 183.00 & 6.50 & 272.81 \\ \text { J3 } & \text { W1-CS134 } & 3 & 10-23-86 & 144.00 & 6.90 & 272.81\end{array}$

$\begin{array}{lrrrrr}\operatorname{MEAN} & = & 177.7 & \text { Lab Est. Rel. Error }= & 0.07 \\ \mathrm{BR}(5 \%)= & -0.54 \text { BR }= & -0.35 & \text { BR }(95 \%)= & -0.16 \\ \text { SA }(5 \%)= & 0.10 & \text { SA }= & 0.18 & \text { SA }(95 \%)= & 0.78 \\ \text { SB }(5 \%)= & 0.07 \text { SB }= & 0.11 & \text { SB }(95 \%)= & 0.51\end{array}$

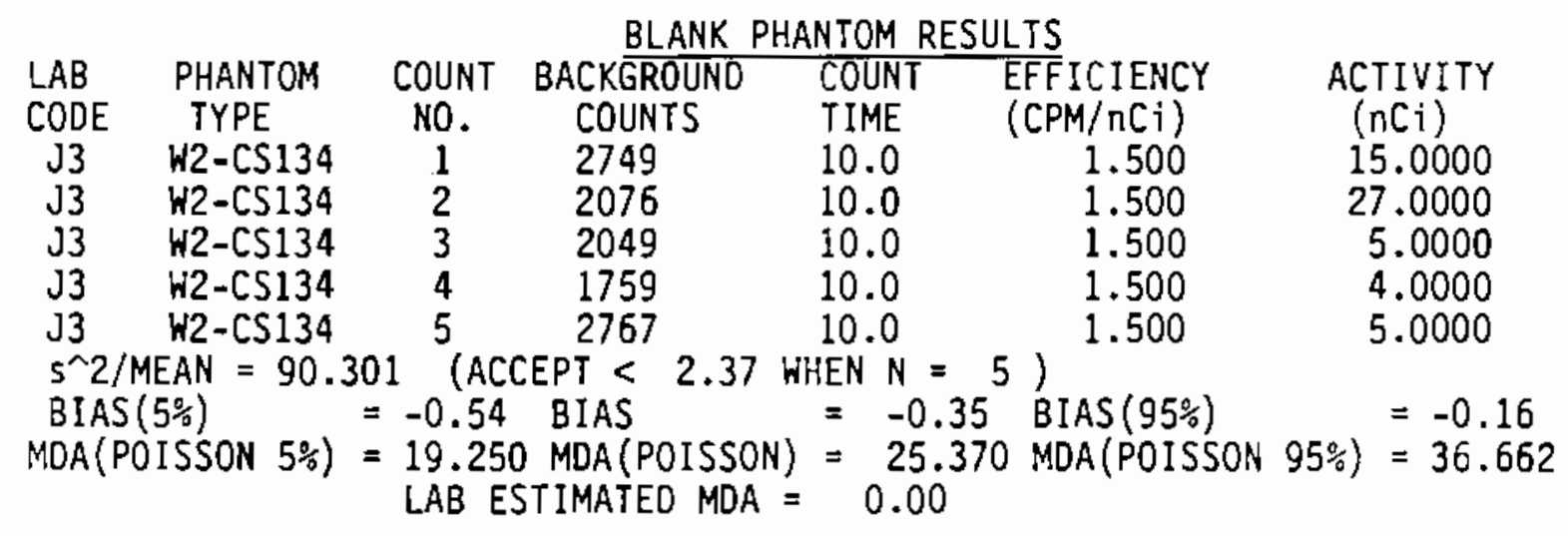




$\begin{array}{llccrcr}\text { LAB } & \text { PHANTOM } & \text { COUNT } & \text { DATE } & \text { LAB ASSAY } & \text { ERROR(\%) } & \text { TRUE } \\ \text { COOE } & \text { TYPE } & \text { NO. } & \text { COUNTED } & \text { (nCi) } & & \text { SPIKE } \\ \text { J3 } & \text { W1-CS137 } & 1 & 10-23-86 & 213.00 & 5.70 & 358.50 \\ \text { J3 } & \text { W1-CS137 } & 2 & 10-23-86 & 226.00 & 5.30 & 358.50 \\ \text { J3 } & \text { W1-CS137 } & 3 & 10-23-86 & 262.00 & 5.00 & 358.50\end{array}$

$\begin{array}{lllll}\text { MEAN }= & 233.7 & \text { Lab Est, Rel. Error }= & 0.05 \\ \text { BR }(5 \%)= & -0.47 \text { BR }= & -0.35 \text { BR }(95 \%)= & -0.23 \\ \text { SA }(5 \%)= & 0.06 \text { SA }= & 0.11 \text { SA }(95 \%)= & 0.48 \\ \text { SB }(5 \%)= & 0.04 & \text { SB }= & 0.07 \text { SB }(95 \%)= & 0.31\end{array}$

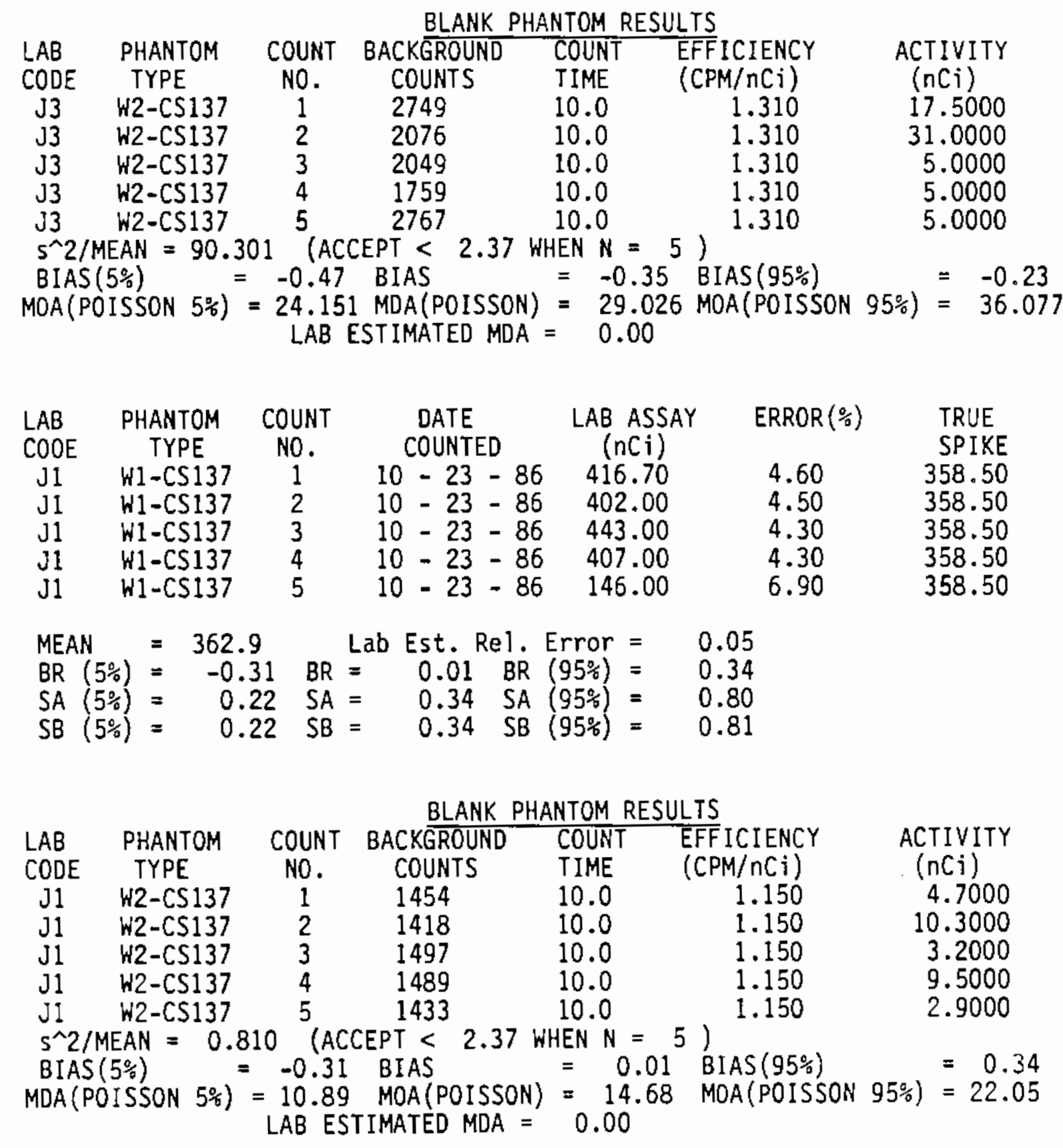




$\begin{array}{llccccc}\text { LAB } & \text { PHANTOM } & \text { COUNT } & \text { DATE } & \text { LAB ASSAY } & \text { ERROR }(\%) & \text { TRUE } \\ \text { CODE } & \text { TYPE } & \text { NO. } & \text { COUNTED } & \text { (nCi) } & & \text { SPIKE } \\ \text { J1 } & \text { W1-CS134 } & 1 & 10-23-86 & 287.00 & 6.30 & 272.81 \\ \text { J1 } & \text { W1-CS134 } & 2 & 10-23-86 & 418.00 & 4.70 & 272.81\end{array}$

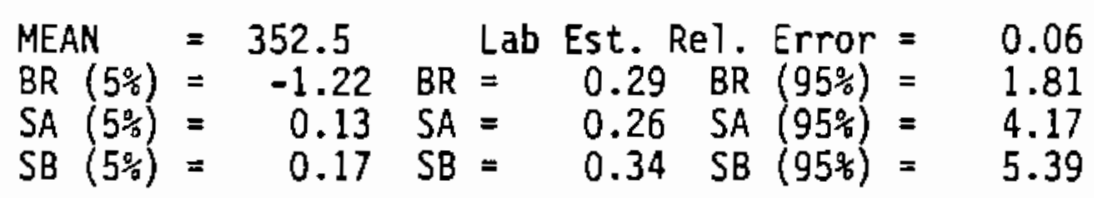

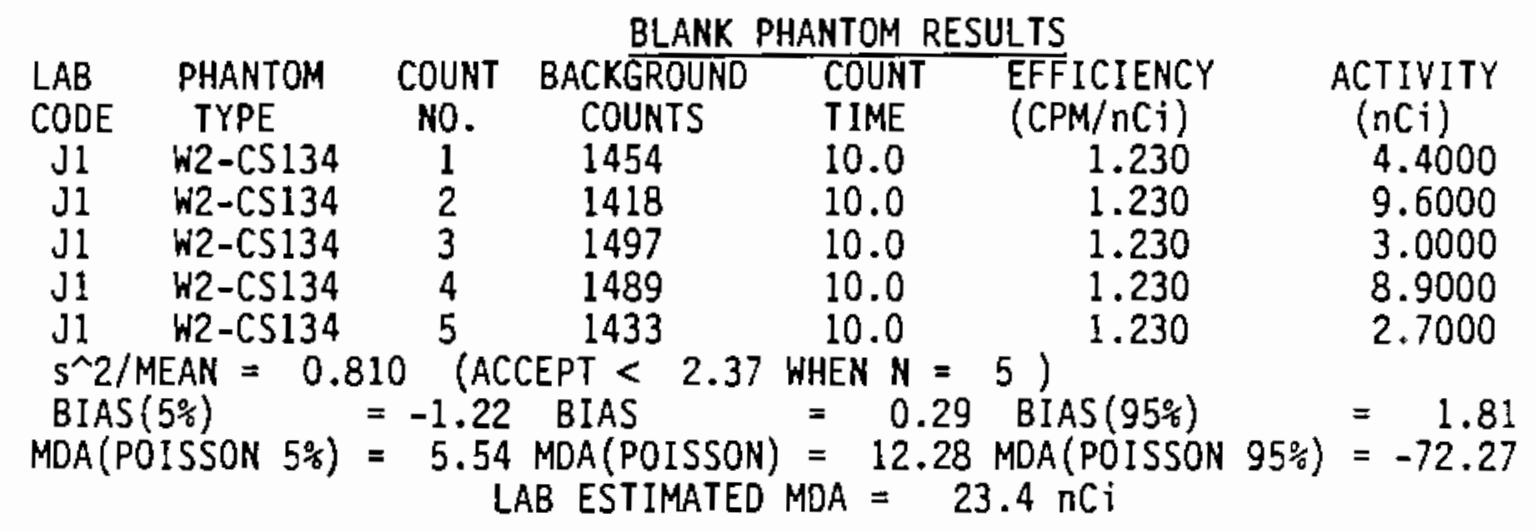

\begin{tabular}{llccccr} 
LAB & PHANTOM & COUNT & DATE & LAB ASSAY & ERROR $(\%)$ & \multicolumn{1}{c}{ TRUE } \\
CODE & TYPE & NO. & COUNTED & $(n C i)$ & & SPIKE \\
J2 & W1-CS137 & 1 & $10-23-86$ & 185.00 & 6.50 & 358.50 \\
J2 & W1-CS137 & 2 & $10-23-86$ & 185.00 & 5.20 & 358.50 \\
J2 & W1-CS137 & 3 & $10-23-86$ & 356.00 & 4.60 & 358.50 \\
J2 & W1-CS137 & 4 & $10-23-86$ & 410.00 & 4.50 & 358.50
\end{tabular}

$\begin{array}{lrllll}\text { MEAN } & =284.0 & \text { Lab Est. Rel. Error }= & 0.05 \\ \text { BR }(5 \%)= & -0.59 & \mathrm{BR}= & -0.21 & \mathrm{BR}(95 \%)= & 0.17 \\ \mathrm{SA}(5 \%)= & 0.25 & \mathrm{SA}= & 0.41 \mathrm{SA}(95 \%)= & 1.20 \\ \mathrm{SB}(5 \%)= & 0.20 & \mathrm{SB}= & 0.32 \mathrm{SB}(95 \%)= & 0.95\end{array}$

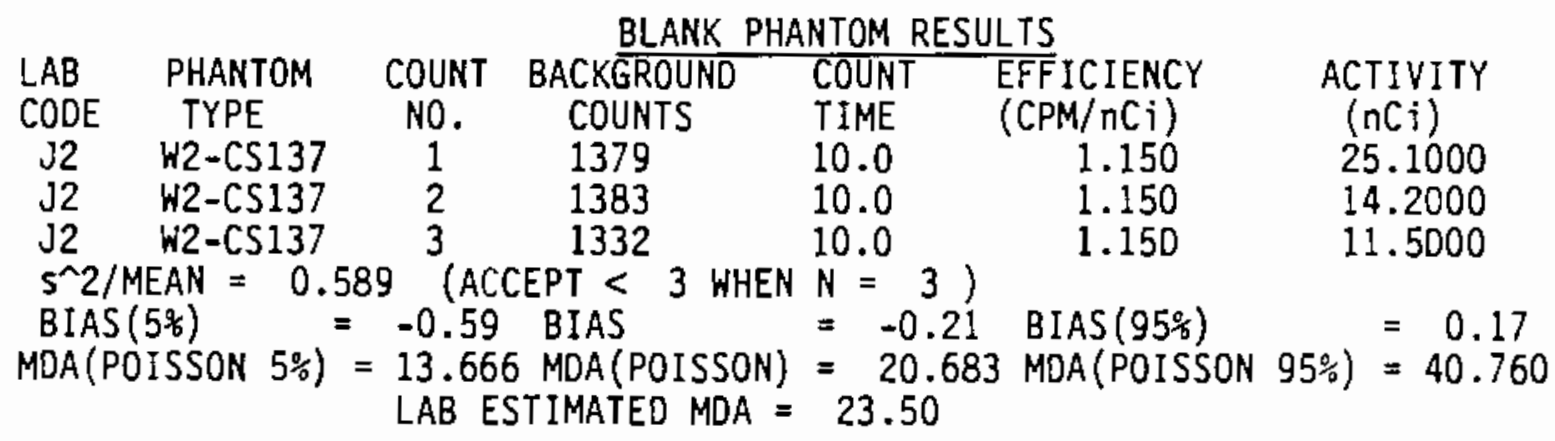


BLANK PHANTOM RESULTS

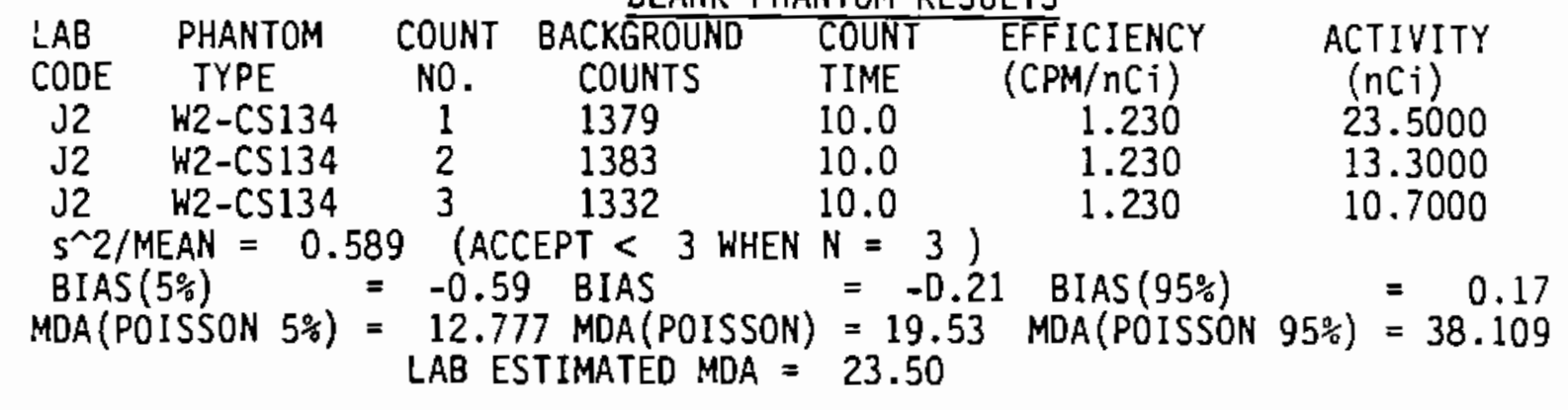

$\begin{array}{lcccccc}\text { LAB } & \text { PHANTOM } & \text { COUNT } & \text { DATE } & \text { LAB ASSAY } & \text { ERROR }(\%) & \text { TRUE } \\ \text { CODE } & \begin{array}{c}\text { TYPE } \\ \text { NO }\end{array} & \text { NO. } & \text { COUNTED } & (\mathrm{nCi}) & & \text { SPIKE } \\ \text { K } & \text { P2-PU238 } & 1 & 1-9-87 & 18.10 & 0.00 & 32.38 \\ \text { K } & \text { P2-PU238 } & 2 & 1-9-87 & 24.80 & 0.00 & 32.38 \\ \text { K } & \text { P2-PU238 } & 3 & 1-9-87 & 23.20 & 0.00 & 32.38 \\ \text { K } & \text { P2-PU238 } & 4 & 1-9-87 & 17.30 & 0.00 & 32.38 \\ \text { K } & \text { P2-PU238 } & 5 & 1-9-87 & 19.20 & 0.00 & 32.38\end{array}$

\begin{tabular}{|c|c|c|c|c|c|c|c|c|}
\hline $\begin{array}{l}\text { MEAN } \\
\text { BR }(5 \%) \\
\text { SA }(5 \%) \\
\text { SB }(5 \%)\end{array}$ & $\begin{array}{l}= \\
= \\
= \\
=\end{array}$ & $\begin{array}{l}20.5 \\
-0.46 \\
0.10 \\
0.07\end{array}$ & $\begin{array}{l}\text { BR } \\
\text { SA } \\
\text { SB }\end{array}$ & $\begin{array}{l}\text { Lab } \\
= \\
= \\
=\end{array}$ & $\begin{array}{l}\text { Est. } \\
-0.37 \\
0.16 \\
0.10\end{array}$ & $\begin{array}{r}\mathrm{Re} 1 . \\
B R \\
S A \\
S B\end{array}$ & $\begin{array}{l}\text { Error } \\
(95 \%) \\
(95 \%) \\
(95 \%)\end{array}$ & \\
\hline
\end{tabular}

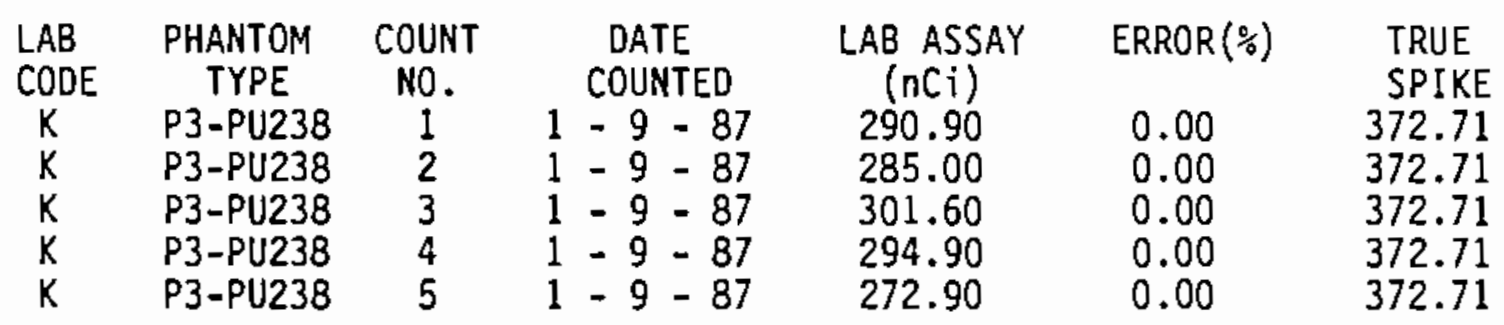

\begin{tabular}{|c|c|c|c|c|c|c|c|c|}
\hline $\begin{array}{l}\text { MEAN } \\
\text { BR } \quad(5 \%) \\
\text { SA } \quad 5 \%) \\
\text { SB }(5 \%)\end{array}$ & $\begin{array}{l}= \\
= \\
=\end{array}$ & $\begin{array}{r}289.1 \\
-0.25 \\
0.02 \\
0.02\end{array}$ & $\begin{array}{l}B R \\
S A \\
S B\end{array}$ & $\begin{array}{l}\text { Lab } \\
= \\
= \\
=\end{array}$ & $\begin{array}{l}\text { Est. } \\
-0.22 \\
0.04 \\
0.03\end{array}$ & $\begin{array}{r}\text { Rel. } \\
\text { BR } \\
\text { SA } \\
\text { SB }\end{array}$ & $\begin{array}{l}\text { Error } \\
(95 \%) \\
(95 \%) \\
(95 \%)\end{array}$ & \\
\hline
\end{tabular}

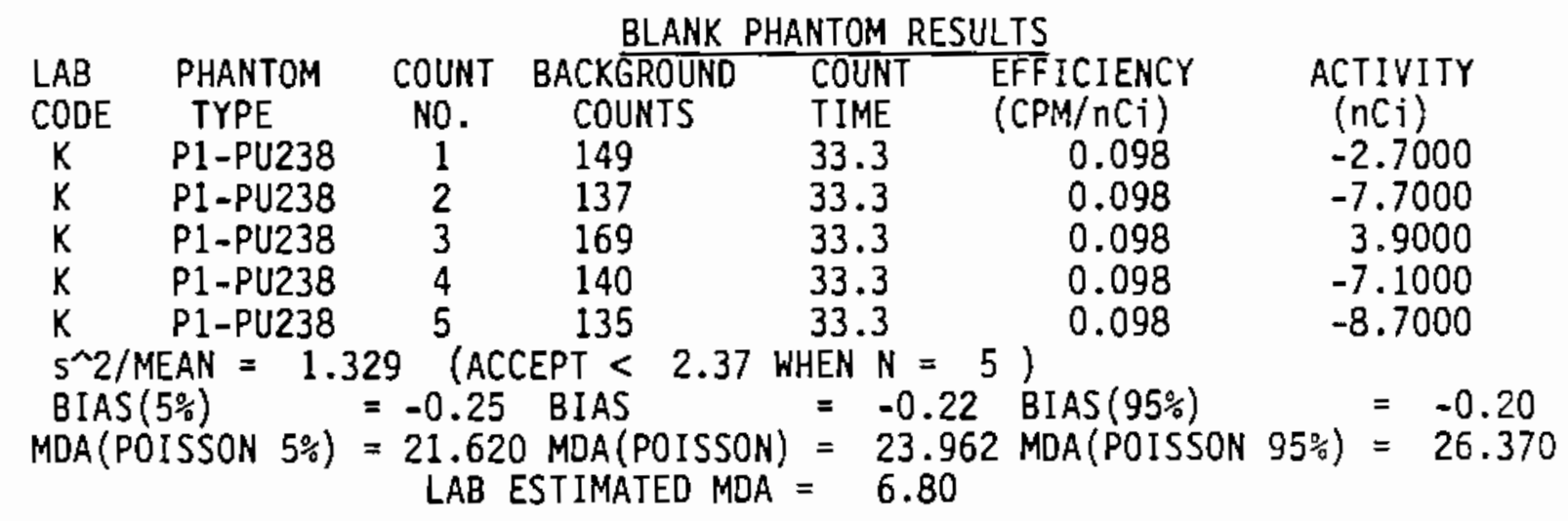




\begin{tabular}{|c|c|c|c|c|c|c|}
\hline $\begin{array}{l}\text { LAB } \\
\text { CODE }\end{array}$ & $\begin{array}{c}\text { PHANTOM } \\
\text { TYPE }\end{array}$ & $\begin{array}{c}\text { COUNT } \\
\text { NO. }\end{array}$ & $\begin{array}{l}\text { DATE } \\
\text { COUNTED }\end{array}$ & $\begin{array}{c}\text { LAB ASSAY } \\
(n C i)\end{array}$ & ERROR $\%)$ & $\begin{array}{l}\text { TRUE } \\
\text { SPIKE }\end{array}$ \\
\hline $\mathrm{K}$ & U3-U238 & 1 & $1-6-87$ & 2.74 & 0.00 & 3.51 \\
\hline$k$ & U3-U238 & 2 & $1-6-87$ & 2.29 & 0.00 & \\
\hline K & U3-U238 & 3 & $1-6-87$ & 2.09 & 0.00 & \\
\hline$k$ & U3-U238 & 4 & $1-6-87$ & 3.17 & 0.00 & \\
\hline K & U3-U238 & 5 & $1-6-87$ & 2.95 & 0.00 & 51 \\
\hline
\end{tabular}

\begin{tabular}{|c|c|c|c|c|c|c|c|c|c|}
\hline $\begin{array}{l}\text { MEAN } \\
\text { BR }(5 \%) \\
\text { SA }(5 \%) \\
\text { SB } \quad(5 \%)\end{array}$ & $=$ & $\begin{array}{c}2.6 \\
-0.37 \\
0.11 \\
0.08\end{array}$ & $\begin{array}{l}\text { BR } \\
\text { SA } \\
\text { SB }\end{array}$ & $\begin{array}{l}\text { Lab } \\
= \\
= \\
=\end{array}$ & $\begin{array}{l}\text { Est. } \\
-0.25 \\
0.17 \\
0.13\end{array}$ & $\begin{array}{r}\text { Rel } \\
\text { BR } \\
\text { SA } \\
\text { SB }\end{array}$ & $\begin{array}{l}\text { Error } \\
(95 \%) \\
(95 \%) \\
(95 \%)\end{array}$ & & $\begin{array}{r}0.00 \\
-0.12 \\
0.40 \\
0.30\end{array}$ \\
\hline
\end{tabular}

$\begin{array}{lcccccc}\text { LAB } & \text { PHANTOM } & \text { COUNT } & \text { DATE } & \text { LAB ASSAY } & \text { ERROR( } 5) & \text { TRUE } \\ \text { CODE } & \text { TYPE } & \text { NO. } & \text { COUNTED } & \text { (nCi) } & & \text { SPIKE } \\ K & \text { U1-U238 } & 1 & 1-2-87 & 30.10 & 0.00 & 33.07 \\ K & U 1-U 238 & 2 & 1-2-87 & 29.80 & 0.00 & 33.07 \\ K & U 1-U 238 & 3 & 1-2-87 & 31.30 & 0.00 & 33.07 \\ K & \text { U1-U238 } & 4 & 1-2-87 & 28.20 & 0.00 & 33.07 \\ K & \text { U1-U238 } & 5 & 1-2-87 & 29.80 & 0.00 & 33.07\end{array}$

\begin{tabular}{|c|c|c|c|c|c|c|c|c|c|}
\hline $\begin{array}{l}\text { MEAN } \\
\text { BR }(5 \%) \\
\text { SA }(5 \%) \\
\text { SB }(5 \%)\end{array}$ & & $\begin{array}{r}29.8 \\
-0.13 \\
0.02 \\
0.02\end{array}$ & $\begin{array}{l}\text { BR } \\
S A \\
S B\end{array}$ & $\begin{array}{l}\text { Lab } \\
= \\
= \\
=\end{array}$ & $\begin{array}{l}\text { Est. } \\
-0.10 \\
0.04 \\
0.03\end{array}$ & $\begin{array}{r}\text { Rel. } \\
\text { BR } \\
\text { SA } \\
\text { SB }\end{array}$ & $\begin{array}{l}\text { Error } \\
(95 \%) \\
(95 \%) \\
(95 \%)\end{array}$ & $\begin{array}{l}= \\
= \\
=\end{array}$ & $\begin{array}{r}0.00 \\
-0.07 \\
0.09 \\
0.08\end{array}$ \\
\hline
\end{tabular}

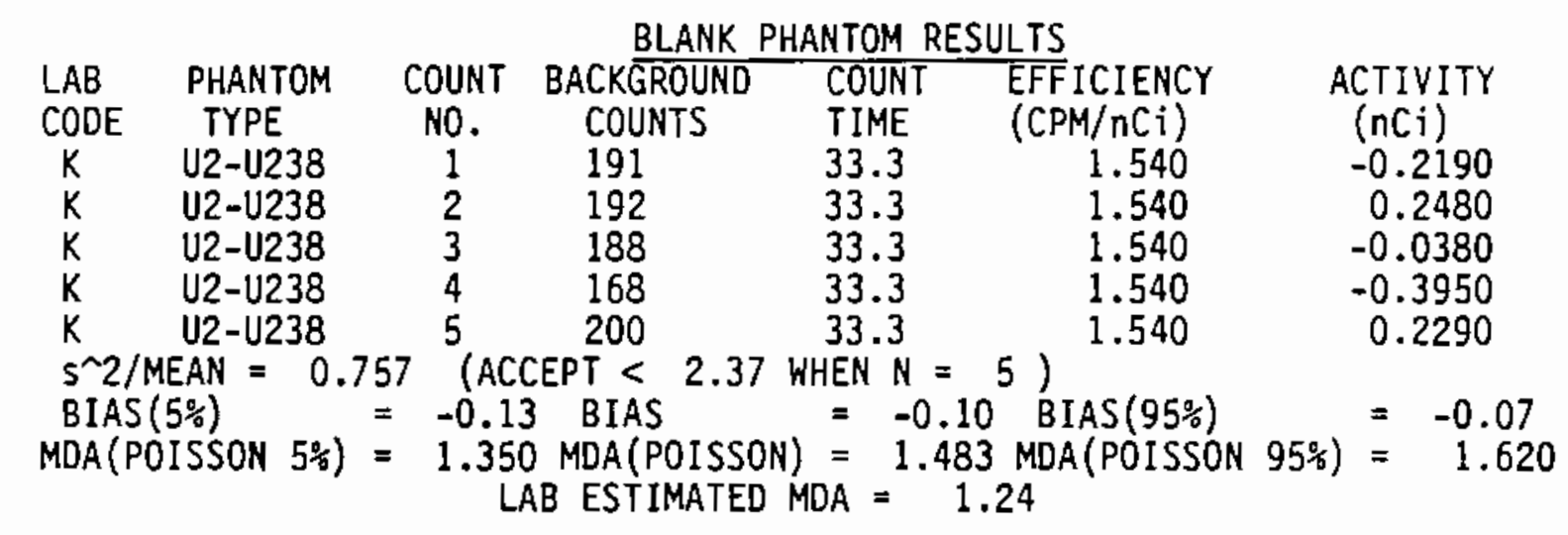

\begin{tabular}{lcccccc} 
LAB & PHANTOM & COUNT & DATE & LAB ASSAY & ERROR(\%) & \multicolumn{1}{c}{ TRUE } \\
CODE & TYPE & N0. & COUNTED & $(\mathrm{nCi})$ & & SPIKE \\
K & M2-CE144 & 1 & $1-15-87$ & 607.00 & 0.00 & 709.07 \\
K & M2-CE144 & 2 & $1-15-87$ & 587.00 & 0.00 & 709.07 \\
K & M2-CE144 & 3 & $1-15-87$ & 522.00 & 0.00 & 709.07 \\
K & M2-CE144 & 4 & $1-15-87$ & 540.00 & 0.00 & 709.07 \\
K & M2-CE144 & 5 & $1-15-87$ & 598.00 & 0.00 & 709.07
\end{tabular}

\begin{tabular}{|c|c|c|c|c|c|c|c|}
\hline $\begin{array}{l}\text { MEAN } \\
\text { BR }(5 \%) \\
\text { SA } \quad(5 \%) \\
\text { SB }(5 \%)\end{array}$ & & $\begin{array}{r}570.8 \\
-0.25 \\
0.04 \\
0.03\end{array}$ & $\begin{array}{l}\text { BR } \\
S A \\
S B\end{array}$ & $\begin{array}{l}\text { Lab } \\
= \\
= \\
=\end{array}$ & $\begin{array}{r}\text { Est. } \\
-0.20 \\
0.07 \\
0.05\end{array}$ & $\begin{array}{r}\text { Re I. } \\
\text { BR } \\
\text { SA } \\
\text { SB }\end{array}$ & $\begin{array}{l}\text { Error } \\
(95 \%) \\
(95 \%) \\
(95 \%)\end{array}$ \\
\hline
\end{tabular}




$\begin{array}{lcccccc}\text { LAB } & \text { PHANTOM } & \text { COUNT } & \text { DATE } & \text { LAB ASSAY } & \text { ERROR(\%) } & \text { TRUE } \\ \text { CODE } & \text { TYPE } & \text { NO. } & \text { COUNTED } & \text { (nCi) } & & \text { SPIKE } \\ K & \text { M1-CE144 } & 1 & 1-15-87 & 306.00 & 0.00 & 604.57 \\ K & \text { MI-CE144 } & 2 & 1-15-87 & 310.00 & 0.00 & 604.57 \\ K & \text { M1-CE144 } & 3 & 1-15-87 & 317.00 & 0.00 & 604.57 \\ K & \text { M1-CE144 } & 4 & 1-15-87 & 309.00 & 0.00 & 604.57 \\ K & \text { M1-CE144 } & 5 & 1-15-87 & 322.00 & 0.00 & 604.57\end{array}$

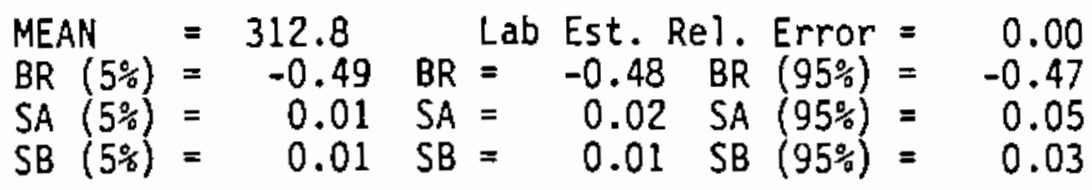

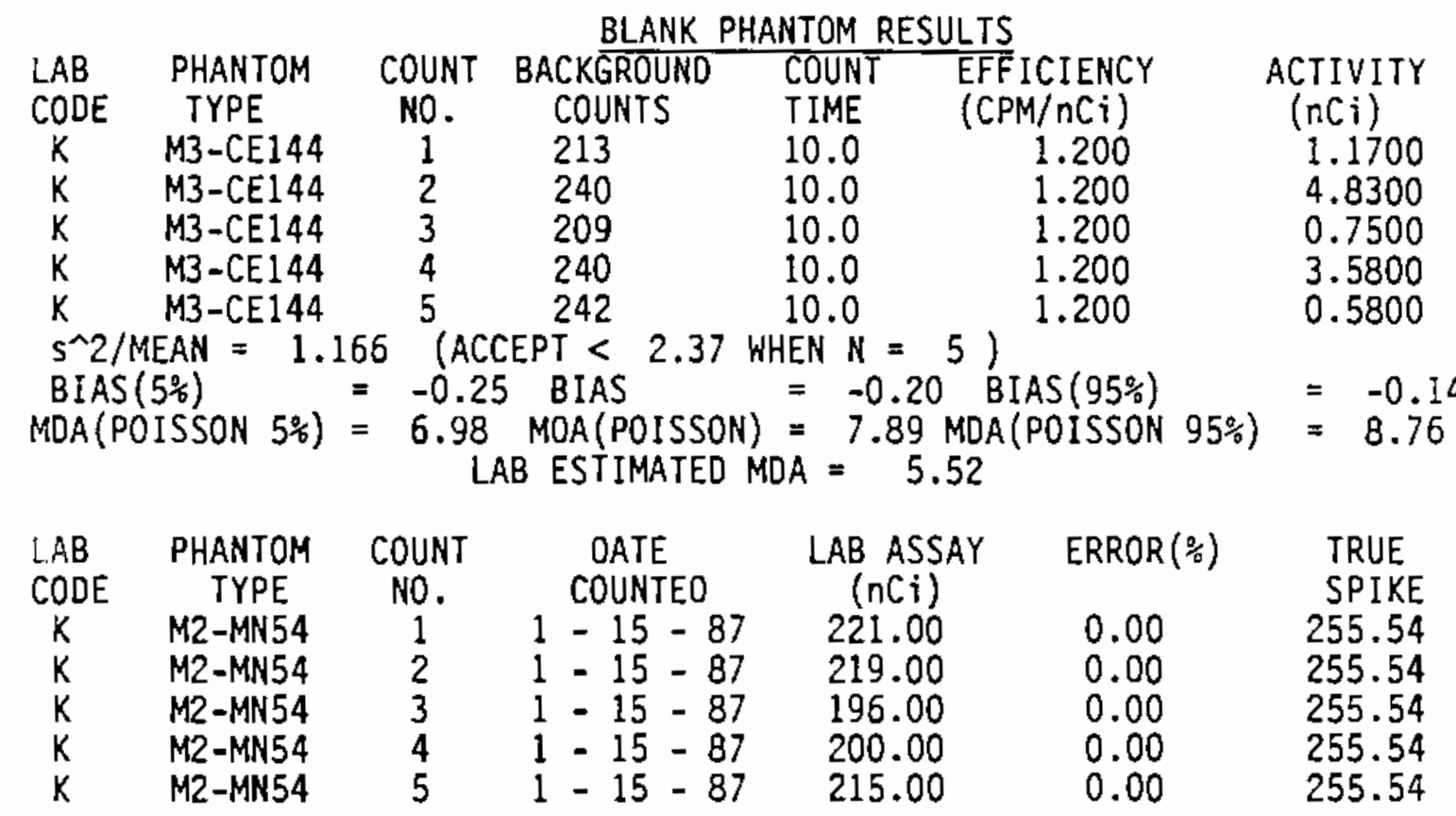

$\begin{array}{lrll}\text { MEAN }= & 210.2 & \text { Lab Est. Re } 1 . \text { Error }= & 0.00 \\ \text { BR }(5 \%)= & -0.22 \text { BR }=-0.18 \text { BR }(95 \%)= & -0.13 \\ \text { SA }(5 \%)=0.04 & \text { SA }=0.05 \text { SA }(95 \%)= & 0.13 \\ \text { SB }(5 \%)= & 0.03 \mathrm{SB}=0.04 \mathrm{SB}(95 \%)= & 0.11\end{array}$

\begin{tabular}{lcccccc} 
LAB & PHANTOM & COUNT & OATE & LAB ASSAY & ERROR $(\%)$ & \multicolumn{1}{c}{ TRUE } \\
COOE & TYPE & NO. & COUNTE0 & $($ nCi) & & SPIKE \\
$K$ & M1-MN54 & 1 & $1-15-87$ & 99.00 & 0.00 & 209.79 \\
$K$ & M1-MN54 & 2 & $1-15-87$ & 101.00 & 0.00 & 209.79 \\
$K$ & M1-MN54 & 3 & $1-15-87$ & 101.00 & 0.00 & 209.79 \\
$K$ & M1-MN54 & 4 & $1-15-87$ & 103.00 & 0.00 & 209.79 \\
$K$ & M1-MN54 & 5 & $1-15-87$ & 97.00 & 0.00 & 209.79
\end{tabular}

\begin{tabular}{|c|c|c|c|c|c|c|c|c|}
\hline $\begin{array}{l}\text { MEAN } \\
\text { BR }(5 \%) \\
\text { SA }(5 \%) \\
\text { SB }(5 \%)\end{array}$ & $\begin{array}{l}= \\
= \\
=\end{array}$ & $\begin{array}{r}100.2 \\
-0.53 \\
0.01 \\
0.01\end{array}$ & $\begin{array}{l}\text { BR } \\
\text { SA } \\
\text { SB }\end{array}$ & $\begin{array}{l}\text { Lab } \\
= \\
= \\
=\end{array}$ & $\begin{array}{l}\text { Est. } \\
-0.52 \\
0.02\end{array}$ & $\left\{\begin{array}{l}\mathrm{ReI} \\
\mathrm{BR} \\
\mathrm{SA} \\
\mathrm{SB}\end{array}\right.$ & $\begin{array}{l}\text { Error } \\
(95 \%) \\
(95 \%) \\
(95 \%)\end{array}$ & \\
\hline
\end{tabular}


BLANK PHANTOM RESULTS

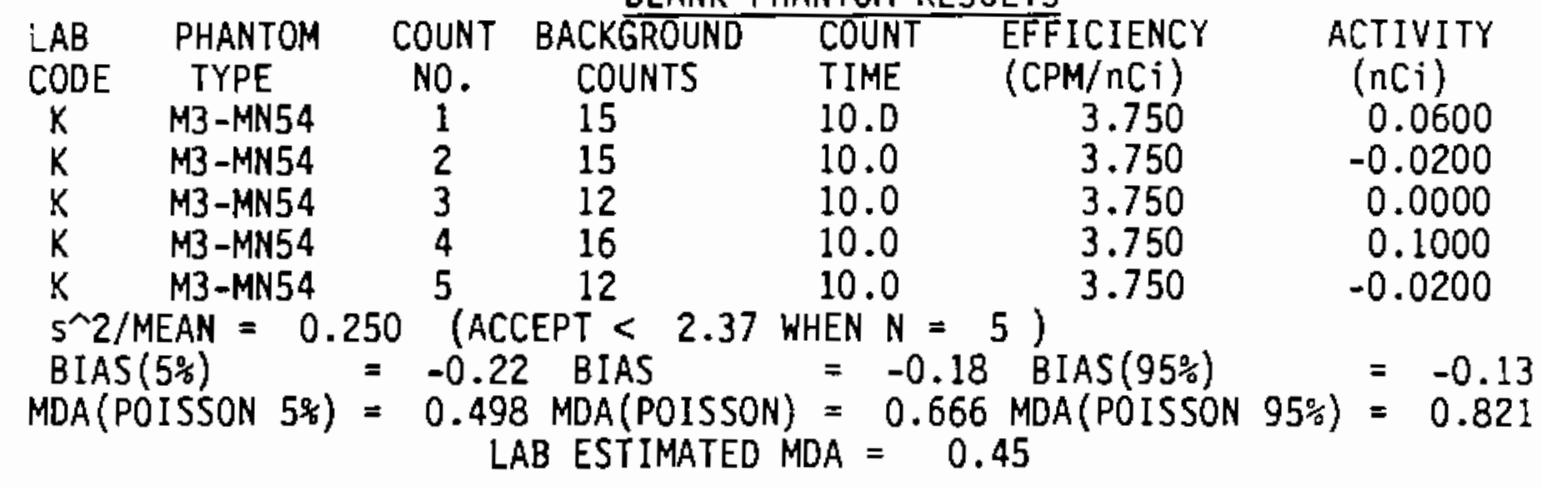

$\begin{array}{llccccc}\text { LAB } & \text { PHANTOM } & \text { COUNT } & \text { DATE } & \text { LAB ASSAY } & \text { ERROR(\%) } & \text { TRUE } \\ \text { CODE } & \text { TYPE } & \text { NO. } & \text { COUNTED } & \begin{array}{c}\text { (nCi) } \\ \text { SPIKE }\end{array} & & \\ \text { L } & \text { W1-CS134 } & 1 & 1-10-89 & 130.00 & 4.30 & 129.38 \\ \text { L } & \text { W1-CS134 } & 2 & 1-10-89 & 150.00 & 3.70 & 129.38 \\ \text { L } & \text { W1-CS134 } & 3 & 1-10-89 & 140.00 & 4.70 & 129.38 \\ L & \text { W1-CS134 } & 4 & 1-10-89 & 120.00 & 4.10 & 129.38 \\ L & \text { W1-CS134 } & 5 & 1-10-89 & 130.00 & 4.00 & 129.38\end{array}$

MEAN $=134.0 \quad$ Lab Est. Rel. Error $=0$
BR $(5 \%)=0.04$
SA $(5 \%)=0.06$ BR $=0.04$ BR $(95 \%)=0.12$
SB $(5 \%)=0.06$ SB $=0.09$ SA $(95 \%)=0.20$
SB $(95 \%)=0.21$

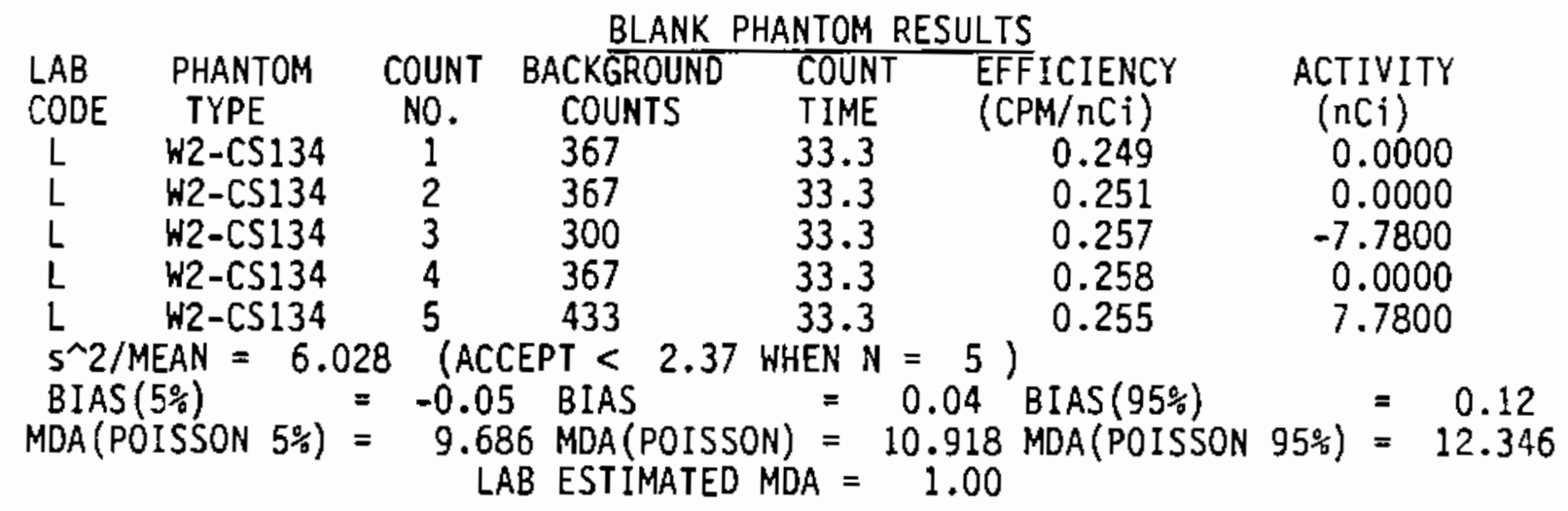

$\begin{array}{llccccc}\text { LAB } & \text { PHANTOM } & \text { COUNT } & \text { DATE } & \text { LAB ASSAY } & \text { ERROR }(\%) & \text { TRUE } \\ \text { CODE } & \text { TYPE } & \text { NO. } & \text { COUNTED } & \text { (nCi) } & & \text { SPIKE } \\ \text { L } & \text { W1-CS134 } & 1 & 1-10-89 & 130.00 & 4.10 & 129.38 \\ \text { L } & \text { W1-CS134 } & 2 & 1-10-89 & 150.00 & 3.60 & 129.38 \\ \text { L } & \text { W1-CS134 } & 3 & 1-10-89 & 140.00 & 3.80 & 129.38 \\ \text { L } & \text { W1-CS134 } & 4 & 1-10-89 & 120.00 & 4.30 & 129.38 \\ \text { L } & \text { WI-CS134 } & 5 & 1-10-89 & 130.00 & 3.80 & 129.38\end{array}$

MEAN $=134.0 \quad$ Lab Est. Rel. Error $=0.04$
BR $(5 \%)=-0.05$ BR $=0.04$ BR $(95 \%)=0.12$
SA $(5 \%)=0.06$ SA $=0.09$ SA $(95 \%)=0.20$
SB $(5 \%)=0.06 \mathrm{SB}=0.09 \mathrm{SB}(95 \%)=0.21$


BLANK PHANTOM RESULTS

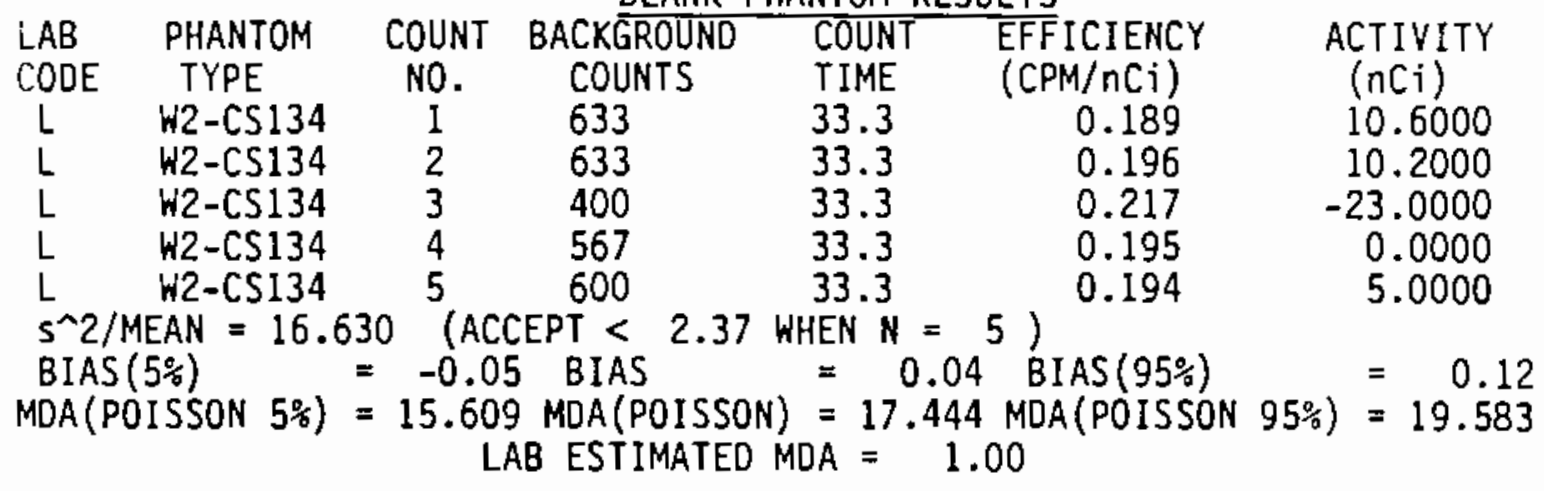

$\begin{array}{llccccc}\text { LAB } & \text { PHANTOM } & \text { COUNT } & \text { DATE } & \text { LAB ASSAY } & \text { ERROR }(\%) & \text { TRUE } \\ \text { CODE } & \text { TYPE } & \text { NO. } & \text { COUNTED } & \text { (nCi) } & & \text { SPIKE } \\ \text { L } & \text { WI-CSI37 } & 1 & 1-10-89 & 320.00 & 2.30 & 340.71 \\ \text { L } & W I-C S 137 & 2 & 1-10-89 & 380.00 & 2.10 & 340.71 \\ \text { L } & W 1-C S 137 & 3 & 1-10-89 & 380.00 & 2.20 & 340.71 \\ \text { L } & W 1-C S I 37 & 4 & 1-10-89 & 320.00 & 2.30 & 340.69 \\ \text { L } & W 1-C S 137 & 5 & 1-10-89 & 340.00 & 2.20 & 340.69\end{array}$

$\begin{array}{lllllll}\text { MEAN } & = & 348.0 & \text { Lab Est. Rel. Error }= & 0.02 \\ \mathrm{BR}(5 \%)= & -0.06 & \mathrm{BR}= & 0.02 & \mathrm{BR}(95 \%)= & 0.1 \mathrm{I} \\ \mathrm{SA}(5 \%) & =0.06 & \mathrm{SA}= & 0.09 & \mathrm{SA}(95 \%)= & 0.21 \\ \mathrm{SB}(5 \%)= & 0.06 & \mathrm{SB}= & 0.09 \mathrm{SB}(95 \%)= & 0.21\end{array}$

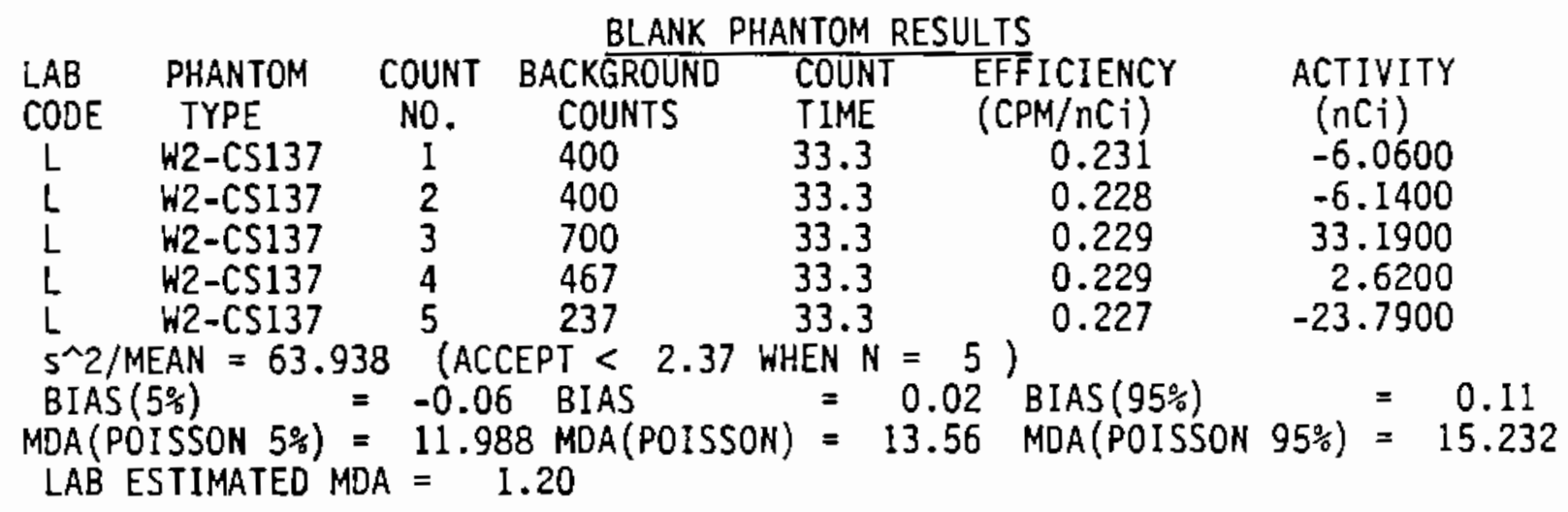




\begin{tabular}{llccccr} 
LAB & PHANTOM & COUNT & DATE & LAB ASSAY & ERROR(\%) & \multicolumn{1}{c}{ TRUE } \\
CODE & TYPE & NO. & COUNTED & $(\mathrm{nCi})$ & & SPIKE \\
M1 & W1-CS134 & 1 & $5-4-87$ & 213.90 & 4.70 & 228.38 \\
M1 & W1-CS134 & 2 & $5-4-87$ & 207.70 & 4.80 & 228.38 \\
M1 & W1-CS134 & 3 & $5-4-87$ & 208.80 & 5.30 & 228.38 \\
M1 & W1-CS134 & 4 & $5-4-87$ & 200.20 & 4.50 & 228.38 \\
M1 & W1-CS134 & 5 & $5-4-87$ & 219.10 & 4.60 & 228.38
\end{tabular}

$\begin{array}{llll}\text { MEAN } & =209.9 & \text { Lab Est. Rel. Error }= & 0.05 \\ \text { BR }(5 \%)= & -0.11 \text { BR }=-0.08 \text { BR }(95 \%)= & -0.05 \\ \text { SA }(5 \%)=0.02 & \text { SA }=0.03 \text { SA }(95 \%)= & 0.08 \\ \text { SB }(5 \%) & =0.02 & \text { SB }=0.03 \text { SB }(95 \%)= & 0.07\end{array}$

\begin{tabular}{|c|c|c|c|c|c|c|}
\hline $\begin{array}{l}\angle A B \\
\text { CODE } \\
M 1 \\
M 1 \\
M 1 \\
M 1 \\
M 1\end{array}$ & $\begin{array}{l}\text { PHANTOM } \\
\text { TYPE } \\
W 1-C S 137 \\
W 1-C S 137 \\
W 1-C S 137 \\
W 1-C S 137 \\
W 1-C S 137\end{array}$ & $\begin{array}{c}\text { COUNT } \\
\text { NO. } \\
1 \\
2 \\
3 \\
4 \\
5\end{array}$ & $\begin{array}{c}\text { DATE } \\
\text { COUNTED } \\
5=4-87 \\
5-4=87 \\
5-4=87 \\
5-4-87 \\
5-4=87\end{array}$ & $\begin{array}{c}\text { LAB ASSAY } \\
(\mathrm{nC} \mathrm{i}) \\
373.60 \\
387.90 \\
377.90 \\
404.90 \\
373.90\end{array}$ & $\begin{array}{l}2.00 \\
1.80 \\
2.10 \\
1.80 \\
2.10\end{array}$ & $\begin{array}{l}\text { TRUE } \\
\text { SPIKE } \\
354.18 \\
354.18 \\
354.18 \\
354.18 \\
354.18\end{array}$ \\
\hline
\end{tabular}

$\begin{array}{lllll}\operatorname{MEAN} & =383.6 & \text { Lab Est. Rel. Error }= & 0.02 \\ \mathrm{BR}(5 \%) & =0.05 \mathrm{BR}= & 0.08 \text { BR }(95 \%)= & 0.12 \\ \mathrm{SA}(5 \%)= & 0.02 \mathrm{SA}= & 0.03 \mathrm{SA}(95 \%)= & 0.08 \\ \mathrm{SB}(5 \%)= & 0.02 \mathrm{SB}= & 0.04 \mathrm{SB}(95 \%)= & 0.09\end{array}$

\begin{tabular}{|c|c|c|c|c|c|c|}
\hline $\begin{array}{l}\text { LAB } \\
\text { CODE } \\
M 1 \\
M 1 \\
M 1 \\
M 1 \\
M 1\end{array}$ & $\begin{array}{l}\text { PHANTOM } \\
\text { TYPE } \\
\text { M2-CE144 } \\
\text { M2-CE144 } \\
\text { M2-CE144 } \\
\text { M2-CE144 } \\
\text { M2-CE144 }\end{array}$ & $\begin{array}{c}\text { COUNT } \\
\text { NO. } \\
1 \\
2 \\
3 \\
4 \\
5\end{array}$ & $\begin{array}{c}\text { DATE } \\
\text { COUNTED } \\
8-18-87 \\
8-18=87 \\
8-18-87 \\
8-18-87 \\
8-18=87 \\
8-18\end{array}$ & $\begin{array}{c}\text { LA8 ASSAY } \\
\text { (nCi) } \\
184.50 \\
313.10 \\
248.40 \\
216.40 \\
169.10\end{array}$ & $\begin{array}{l}23.30 \\
23.00 \\
19.50 \\
24.30 \\
23.80\end{array}$ & $\begin{array}{l}\text { TRUE } \\
\text { SPIKE } \\
80.79 \\
80.79 \\
80.79 \\
80.79 \\
80.79\end{array}$ \\
\hline
\end{tabular}

MEAN $=226.3 \quad$ Lab Est. Re1. Error $=0.23$
BR $(5 \%)=1.12$ BR $=1.80$ BR $(95 \%)=2.48$
SA $(5 \%)=0.16$ SA $=0.25$ SA $(95 \%)=0.60$
SB $(5 \%)=0.46$ SB $=0.71$ SB $(95 \%)=1.68$

\begin{tabular}{llccccr} 
LAB & PHANTOM & COUNT & DATE & LAB ASSAY & ERROR(\%) & \multicolumn{1}{c}{ TRUE } \\
CODE & TYPE & NO. & COUNTED & $\begin{array}{c}(\mathrm{nCi}) \\
\text { SPIKE }\end{array}$ & & \\
M1 & M1-CE144 & 1 & $8-18-87$ & 1601.80 & 49.70 & 696.95 \\
M1 & M1-CE144 & 2 & $8-18-87$ & 1616.00 & 34.70 & 696.95 \\
M1 & M1-CE144 & 3 & $8-18-87$ & 1588.80 & 35.70 & 696.95 \\
M1 & M1-CE144 & 4 & $8-18-87$ & 1493.90 & 37.30 & 696.95 \\
M1 & M1-CE144 & 5 & $8-18-87$ & 1525.50 & 37.40 & 696.95
\end{tabular}

$\begin{array}{lllll}\text { MEAN } & =1565.2 & \text { Lab Est. Rel. Error }= & 0.39 \\ \text { BR }(5 \%)= & 1.17 & \text { BR }= & 1.25 \text { BR }(95 \%)= & 1.32 \\ \text { SA }(5 \%)= & 0.02 & \text { SA }= & 0.03 \text { SA }(95 \%)= & 0.08 \\ \text { SB }(5 \%) & =0.05 & \text { SB }= & 0.08 \text { SB }(95 \%)= & 0.18\end{array}$




\begin{tabular}{lcccccr} 
LAB & PHANTOM & COUNT & DATE & LAB ASSAY & ERROR(\%) & \multicolumn{1}{c}{ TRUE } \\
CODE & TYPE & NO. & COUNTED & $(\mathrm{nC}$ ) & & SPIKE \\
M1 & M1-MN54 & 1 & $8-18-87$ & 314.40 & 11.20 & 263.15 \\
M1 & M1-MN54 & 2 & $8-18-87$ & 327.00 & 10.80 & 263.15 \\
M1 & M1-MN54 & 3 & $8-18-87$ & 338.60 & 11.20 & 263.15 \\
M1 & M1-MN54 & 4 & $8-18-87$ & 321.70 & 10.90 & 263.15 \\
M1 & M1-MN54 & 5 & $8-18-87$ & 294.00 & 5.60 & 263.15
\end{tabular}

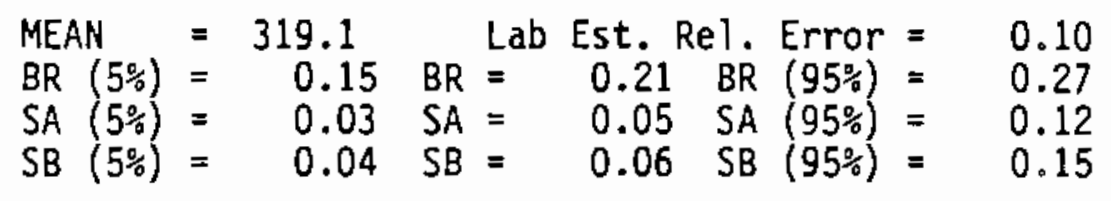

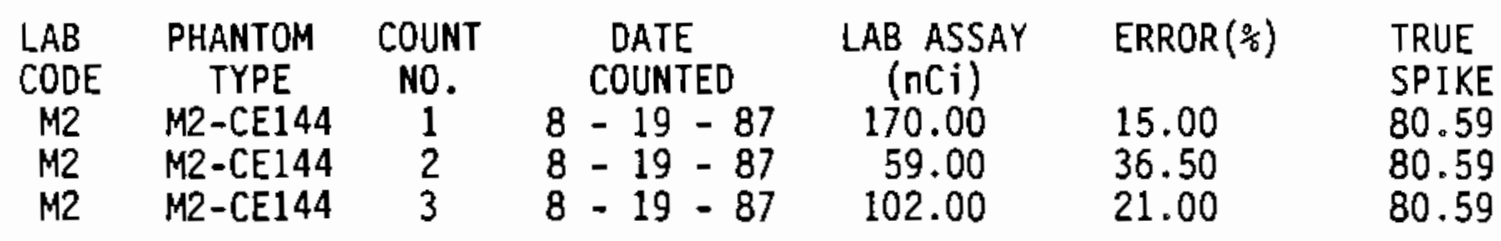

\begin{tabular}{|c|c|c|c|c|c|c|c|c|c|}
\hline $\begin{array}{l}\text { MEAN } \\
\text { BR }(5 \%) \\
\text { SA } \quad(5 \%) \\
\text { SB } \quad(5 \%)\end{array}$ & & $\begin{array}{r}110.3 \\
-0.80 \\
0.29 \\
0.40\end{array}$ & $\begin{array}{l}B R \\
S A \\
S B\end{array}$ & $\begin{array}{l}\text { Lab } \\
= \\
= \\
=\end{array}$ & $\begin{array}{c}\text { Est. } \\
0.37 \\
0.51 \\
0.69\end{array}$ & $\begin{array}{r}\text { Rel } \\
\text { BR } \\
\text { SA } \\
\text { SB }\end{array}$ & & $\begin{array}{l}\text { Error } \\
(95 \%) \\
(95 \%) \\
(95 \%)\end{array}$ & \\
\hline
\end{tabular}

\begin{tabular}{|c|c|c|c|c|c|c|}
\hline $\begin{array}{l}\angle A B \\
\text { CODE } \\
M 2 \\
M 2 \\
M 2 \\
M 2 \\
M 2\end{array}$ & $\begin{array}{l}\text { PHANTOM } \\
\text { TYPE } \\
\text { M1-CE144 } \\
\text { M1-CE144 } \\
\text { M1-CE144 } \\
\text { M1-CE144 } \\
\text { M1-CE144 }\end{array}$ & $\begin{array}{c}\text { COUNT } \\
\text { NO. } \\
1 \\
2 \\
3 \\
4 \\
5\end{array}$ & $\begin{array}{c}\text { DATE } \\
\text { COUNTED } \\
8-19-87 \\
8-19=87 \\
8-19-87 \\
8-19-87 \\
8-19-87\end{array}$ & $\begin{array}{c}\text { LAB ASSAY } \\
(\mathrm{nCi}) \\
830.00 \\
737.00 \\
877.00 \\
728.00 \\
781.00\end{array}$ & $\begin{array}{l}\text { ERROR }(\%) \\
7.00 \\
7.00 \\
5.00 \\
6.00 \\
7.00\end{array}$ & $\begin{array}{c}\text { TRUE } \\
\text { SPIKE } \\
695.25 \\
695.25 \\
695.25 \\
695.25 \\
695.25\end{array}$ \\
\hline
\end{tabular}

\begin{tabular}{|c|c|c|c|c|c|c|c|c|}
\hline $\begin{array}{l}\text { MEAN } \\
\text { BR }(5 \%) \\
\text { SA } \quad(5 \%) \\
\text { SB } \quad(5 \%)\end{array}$ & & $\begin{array}{c}790.6 \\
0.05 \\
0.05 \\
0.06\end{array}$ & $\begin{array}{l}\text { BR } \\
\text { SA } \\
S B\end{array}$ & $\begin{array}{l}\text { Lab } \\
= \\
= \\
=\end{array}$ & $\begin{array}{c}\text { Est. } \\
0.14 \\
0.08 \\
0.09\end{array}$ & $\begin{array}{ll} & \text { Rel. } \\
4 & \text { BR } \\
8 & \text { SA } \\
9 & \text { SB }\end{array}$ & $\begin{array}{l}\text { Error } \\
(95 \%) \\
(95 \%) \\
(95 \%)\end{array}$ & \\
\hline
\end{tabular}




$\begin{array}{lcccccc}\text { LAB } & \text { PHANTOM } & \text { COUNT } & \text { DATE } & \text { LAB ASSAY } & \text { ERROR }(\%) & \text { TRUE } \\ \text { CODE } & \text { TYPE } & \text { N0. } & \text { COUNTED } & (n C i) & & \text { SPIKE } \\ \text { M2 } & \text { M2-MN54 } & 1 & 8-19-87 & 127.00 & 2.00 & 25.85 \\ \text { M2 } & \text { M2-MN54 } & 2 & 8-19-87 & 124.00 & 2.00 & 25.85 \\ \text { M2 } & \text { M2-MN54 } & 3 & 8-19-87 & 126.00 & 2.00 & 25.85 \\ \text { M2 } & \text { M2-MN54 } & 4 & 8-19-87 & 125.00 & 2.00 & 25.85 \\ \text { M2 } & \text { M2-MN54 } & 5 & 8-19-87 & 125.00 & 2.00 & 25.85\end{array}$

$\begin{array}{llll}\text { MEAN } & =125.4 & \text { Lab Est. Rel. Error }= & 0.02 \\ \mathrm{BR}(5 \%) & =3.81 \mathrm{BR}= & 3.85 \mathrm{BR}(95 \%)= & 3.89 \\ \mathrm{SA}(5 \%) & =0.01 \mathrm{SA}= & 0.01 \mathrm{SA}(95 \%)= & 0.02 \\ \mathrm{SB}(5 \%) & =0.03 \mathrm{SB}= & 0.04 \mathrm{SB}(95 \%)= & 0.10\end{array}$

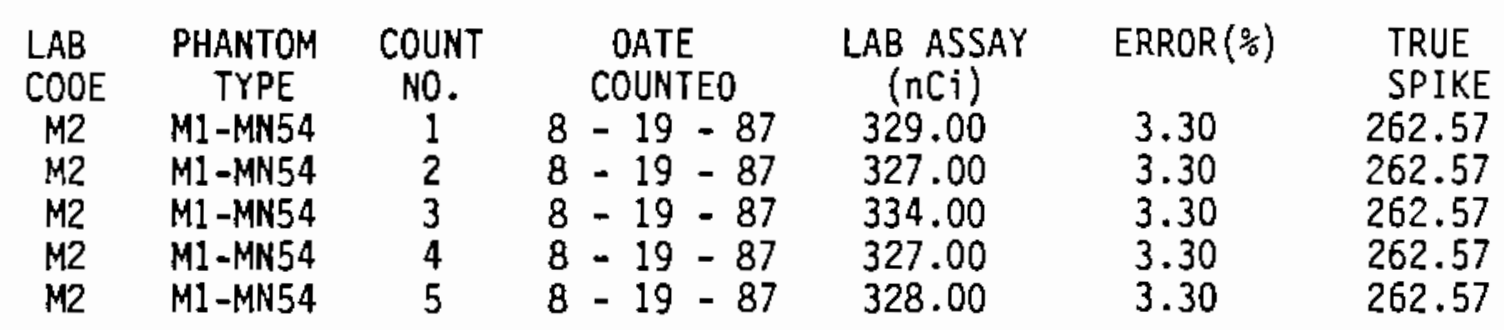

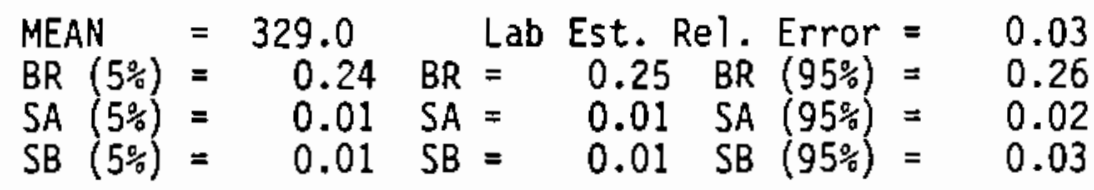

\begin{tabular}{ccccccc} 
LAB & PHANTOM & COUNT & $\begin{array}{c}\text { DATE } \\
\text { COUNTED }\end{array}$ & $\begin{array}{c}\text { LAB ASSAY } \\
(\mathrm{nC} i)\end{array}$ & ERROR(\%) & \multicolumn{1}{l}{ TRUE } \\
CODE & TYPE & NO. & COUNTED & & SPIKE \\
M3 & M2-CE144 & 1 & $8-19-87$ & 56.00 & 26.50 & 80.59 \\
M3 & M2-CE144 & 2 & $8-19-87$ & 39.00 & 30.50 & 80.59 \\
M3 & M2-CE144 & 3 & $8-19-87$ & 155.00 & 10.50 & 80.59 \\
M3 & M2-CEI44 & 4 & $8-19-87$ & 99.00 & 15.50 & 80.59
\end{tabular}

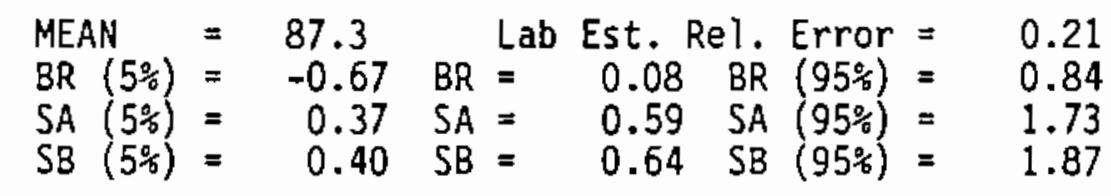

\begin{tabular}{|c|c|c|c|c|c|c|c|}
\hline $\begin{array}{l}\angle A B \\
C O 0 E \\
M 3 \\
M 3 \\
M 3 \\
M 3 \\
M 3\end{array}$ & $\begin{array}{l}\text { PHANTOM } \\
\text { TYPE } \\
\text { M1-CE144 } \\
\text { M1-CE144 } \\
\text { M1-CE144 } \\
\text { MI-CE144 } \\
\text { MI-CE144 }\end{array}$ & $\begin{array}{c}\text { COUNT } \\
\text { NO. } \\
1 \\
2 \\
3 \\
4 \\
5\end{array}$ & $\begin{array}{l}8 \\
8 \\
8 \\
8 \\
8 \\
8\end{array}$ & $\begin{array}{l}\text { DATE } \\
\text { COUNTEO } \\
=19-87 \\
=19-87 \\
-19-87 \\
-19-87 \\
=19-87\end{array}$ & $\begin{array}{c}\text { LAB ASSAY } \\
(\mathrm{nCi}) \\
522.00 \\
543.00 \\
565.00 \\
487.00 \\
542.00\end{array}$ & $\begin{array}{l}7.50 \\
6.50 \\
6.50 \\
7.00 \\
5.50\end{array}$ & $\begin{array}{c}\text { TRUE } \\
\text { SPIKE } \\
695.25 \\
695.25 \\
695.25 \\
695.25 \\
695.25\end{array}$ \\
\hline
\end{tabular}

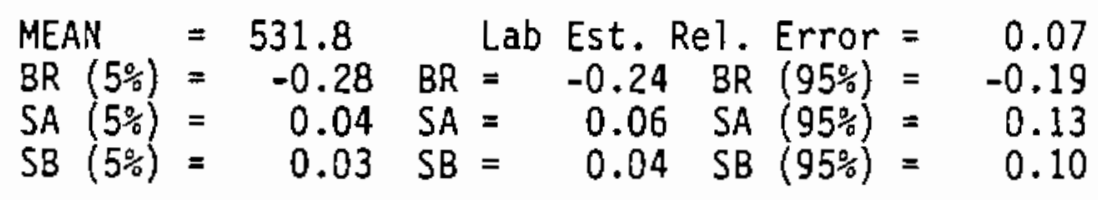




$\begin{array}{lcccccc}\text { LAB } & \text { PHANTOM } & \text { COUNT } & \text { DATE } & \text { LAB ASSAY } & \text { ERROR }(\%) & \text { TRUE } \\ \text { CODE } & \text { TYPE } & \text { NO. } & \text { COUNTED } & \text { (nCi) } & & \text { SPIKE } \\ \text { M3 } & \text { M2-MN54 } & 1 & 8-19-87 & 128.00 & 2.00 & 25.85 \\ \text { M3 } & \text { M2-MN54 } & 2 & 8-19-87 & 121.00 & 3.00 & 25.85 \\ \text { M3 } & \text { M2-MN54 } & 3 & 8-19-87 & 134.00 & 2.00 & 25.85 \\ \text { M3 } & \text { M2-MN54 } & 4 & 8-19-87 & 133.00 & 3.00 & 25.85 \\ \text { M3 } & \text { M2-MN54 } & 5 & 8-19-87 & 138.00 & 2.00 & 25.85\end{array}$

MEAN $=130.8 \quad$ Lab Est. Rel. Error $=0.02$
$B R(5 \%)=3.82$ BR $=4.06$ BR $(95 \%)=4.30$
SA $(5 \%)=0.03$ SA $=0.05$ SA $(95 \%)=0.12$
SB $(5 \%)=0.16 \mathrm{SB}=0.25 \mathrm{SB}(95 \%)=0.60$

\begin{tabular}{lcccccr} 
LAB & PHANTOM & COUNT & DATE & LAB ASSAY & ERROR $(\%)$ & \multicolumn{1}{c}{ TRUE } \\
CODE & TYPE & NO. & COUNTEO & $(\mathrm{nCi})$ & & SPIKE \\
M3 & M1-MN54 & 1 & $8-19-87$ & 359.00 & 1.00 & 262.57 \\
M3 & M1-MN54 & 2 & $8-19-87$ & 370.00 & 1.00 & 262.57 \\
M3 & M1-MN54 & 3 & $8-19-87$ & 371.00 & 1.00 & 262.57 \\
M3 & M1-MN54 & 4 & $8-19-87$ & 365.00 & 1.00 & 262.57 \\
M3 & M1-MN54 & 5 & $8-19-87$ & 372.00 & 1.00 & 262.57
\end{tabular}

$\begin{array}{llllll}\text { MEAN } & = & 367.4 & \text { Lab Est. Rel. Error }= & 0.01 \\ \mathrm{BR}(5 \%)= & 0.38 & \mathrm{BR}= & 0.40 & \mathrm{BR}(95 \%)= & 0.42 \\ \mathrm{SA}(5 \%)= & 0.01 \mathrm{SA}= & 0.01 \mathrm{SA}(95 \%)= & 0.03 \\ \mathrm{SB}(5 \%)= & 0.01 \mathrm{SB}= & 0.02 \mathrm{SB}(95 \%)= & 0.05\end{array}$

$\begin{array}{ccccccc}\text { LAB } & \text { PHANTOM } & \text { COUNT } & \text { DATE } & \text { LAB ASSAY } & \text { ERROR }(\%) & \text { TRUE } \\ \text { CODE } & \text { TYPE } & \text { NO. } & \text { COUNTED } & \text { (nCi) } & & \text { SPIKE } \\ \text { M4 } & \text { M1-CE144 } & 1 & 8-25-87 & 615.00 & 7.00 & 685.15 \\ \text { M4 } & \text { M1-CE144 } & 2 & 8-25-87 & 751.00 & 7.00 & 685.15 \\ \text { M4 } & \text { M1-CE144 } & 3 & 8-25-87 & 864.00 & 5.50 & 685.15 \\ \text { M4 } & \text { M1-CE144 } & 4 & 8-25-87 & 691.00 & 6.50 & 685.15 \\ \text { M4 } & \text { M1-CE144 } & 5 & 8-25-87 & 1401.00 & 3.50 & 685.15\end{array}$

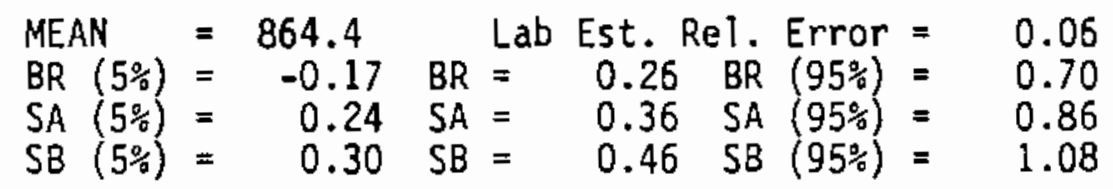

$\begin{array}{lcccccc}\text { LAB } & \text { PHANTOM } & \text { COUNT } & \text { DATE } & \text { LAB ASSAY } & \text { ERROR(\%) } & \text { TRUE } \\ \text { CODE } & \text { TYPE } & \text { NO. } & \text { COUNTED } & \text { (nCi) } & & \text { SPIKE } \\ \text { M4 } & \text { M2-MN54 } & 1 & 8-25-87 & 139.00 & 2.00 & 25.51 \\ \text { M4 } & \text { M2-MN54 } & 2 & 8-25-87 & 141.00 & 2.00 & 25.51 \\ \text { M4 } & \text { M2-MN54 } & 3 & 8-25-87 & 141.00 & 2.00 & 25.51 \\ \text { M4 } & \text { M2-MN54 } & 4 & 8-25-87 & 143.00 & 2.00 & 25.51 \\ \text { M4 } & \text { M2-MN54 } & 5 & 8-25-87 & 136.00 & 2.00 & 25.51\end{array}$

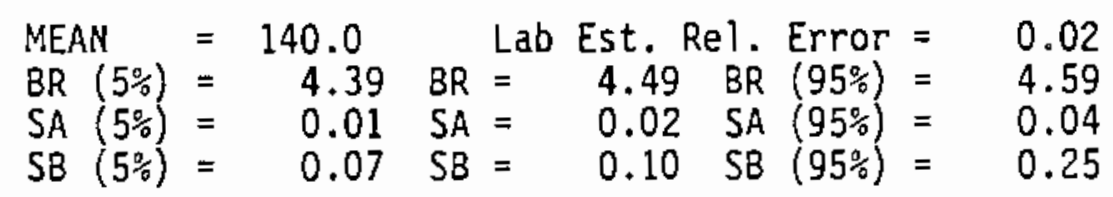




$\begin{array}{lcccccc}\text { LAB } & \text { PHANTOM } & \text { COUNT } & \text { DATE } & \text { LAB ASSAY } & \text { ERROR }(\%) & \text { TRUE } \\ \text { CODE } & \text { TYPE } & \text { NO. } & \text { COUNTED } & \text { (nCi) } & & \text { SPIKE } \\ \text { M4 } & \text { M1-MN54 } & 1 & 8-25-87 & 367.00 & 1.00 & 259.10 \\ \text { M4 } & \text { M1-MN54 } & 2 & 8-25-87 & 367.00 & 1.00 & 259.10 \\ \text { M4 } & \text { M1-MN54 } & 3 & 8-25-87 & 366.00 & 1.00 & 259.10 \\ \text { M4 } & \text { M1-MN54 } & 4 & 8-25-87 & 363.00 & 1.00 & 259.10 \\ \text { M4 } & \text { M1-MN54 } & 5 & 8-25-87 & 370.00 & 1.00 & 259.10\end{array}$

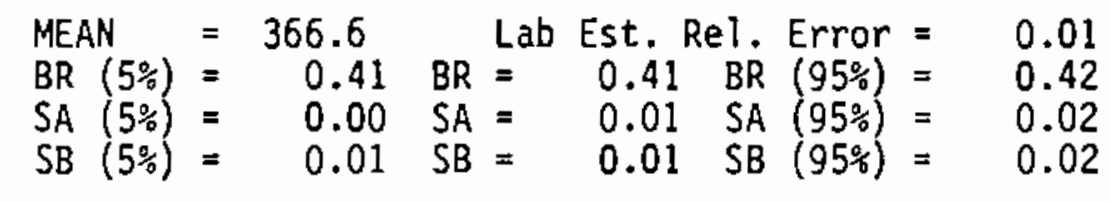

$\begin{array}{llccccc}\text { LAB } & \text { PHANTOM } & \text { COUNT } & \text { DATE } & \text { LAB ASSAY } & \text { ERROR }(\%) & \text { TRUE } \\ \text { CODE } & \text { TYPE } & \text { No. } & \text { COUNTED } & (\mathrm{nCi}) & & \text { SPIKE } \\ \text { M5 } & \text { M2-CE144 } & 1 & 8-25-87 & 57.00 & 32.50 & 79.42 \\ \text { M5 } & \text { M2-CE144 } & 2 & 8-25-87 & 79.00 & 21.00 & 79.42 \\ \text { M5 } & \text { M2-CE144 } & 3 & 8-25-87 & 76.00 & 21.50 & 79.42\end{array}$

\begin{tabular}{|c|c|c|c|c|c|c|c|c|}
\hline $\begin{array}{l}\text { MEAN } \\
\text { BR }(5 \%) \\
\text { SA }(5 \%) \\
\text { SB }(5 \%)\end{array}$ & $\begin{array}{l}= \\
= \\
=\end{array}$ & $\begin{array}{l}70.7 \\
-0.36 \\
0.10 \\
0.09\end{array}$ & $\begin{array}{l}B R \\
S A \\
S B\end{array}$ & $\begin{array}{l}\text { Lab } \\
= \\
= \\
=\end{array}$ & $\begin{array}{r}\text { Est. } \\
-0.11 \\
0.17 \\
0.15\end{array}$ & $\begin{array}{r}\text { Rel } \\
B R \\
S A \\
S B\end{array}$ & $\begin{array}{l}\text { Error } \\
(95 \%) \\
(95 \%) \\
(95 \%)\end{array}$ & $\begin{array}{l}= \\
= \\
= \\
=\end{array}$ \\
\hline
\end{tabular}

\begin{tabular}{lcccccr} 
LAB & PHANTOM & COUNT & DATE & LAB ASSAY & ERROR(\%) & \multicolumn{1}{c}{ TRUE } \\
CODE & TYPE & NO. & COUNTED & $(\mathrm{nCi})$ & & SPIKE \\
M5 & M1-CE144 & 1 & $8-25-87$ & 637.00 & 5.50 & 685.15 \\
M5 & MI-CE144 & 2 & $8-25-87$ & 658.00 & 5.50 & 685.15 \\
M5 & M1-CE144 & 3 & $8-25-87$ & 627.00 & 8.00 & 685.15 \\
M5 & M1-CE144 & 4 & $8-25-87$ & 671.00 & 7.00 & 685.15 \\
M5 & MI-CE144 & 5 & $8-25-87$ & 747.00 & 5.00 & 685.15
\end{tabular}

$\begin{array}{lrlll}\text { MEAN } & =668.0 & \text { Lab Est. Rel. Error }= & 0.06 \\ \text { BR }(5 \%)= & -0.09 & \text { BR }= & -0.03 \text { BR }(95 \%)= & 0.04 \\ \text { SA }(5 \%) & =0.05 \text { SA }= & 0.07 \text { SA }(95 \%)= & 0.17 \\ \text { SB }(5 \%)= & 0.04 \text { SB }= & 0.07 \text { SB }(95 \%)= & 0.16\end{array}$

$\begin{array}{lcccccc}\text { LAB } & \text { PHANTOM } & \text { COUNT } & \text { DATE } & \text { LAB ASSAY } & \text { ERROR }(\%) & \text { TRUE } \\ \text { CODE } & \text { TYPE } & \text { NO. } & \text { COUNTED } & \text { (nCi) } & & \text { SPIKE } \\ \text { M5 } & \text { M2-MN54 } & 1 & 8-25-87 & 134.00 & 2.00 & 25.51 \\ \text { M5 } & \text { M2-MN54 } & 2 & 8-25-87 & 133.00 & 2.00 & 25.51 \\ \text { M5 } & \text { M2-MN54 } & 3 & 8-25-87 & 134.00 & 2.00 & 25.51 \\ \text { M5 } & \text { M2-MN54 } & 4 & 8-25-87 & 134.00 & 2.00 & 25.51 \\ \text { M5 } & \text { M2-MN54 } & 5 & 8-25-87 & 132.00 & 2.00 & 25.51\end{array}$

\begin{tabular}{|c|c|c|c|c|c|c|c|c|}
\hline $\begin{array}{l}\text { MEAN } \\
\text { BR }(5 \%) \\
\text { SA }(5 \%) \\
\text { SB }(5 \%)\end{array}$ & $\begin{array}{l}= \\
= \\
= \\
=\end{array}$ & $\begin{array}{r}133.4 \\
4.20 \\
0.00 \\
0.02\end{array}$ & $\begin{array}{l}\text { BR } \\
\text { SA } \\
\text { SB }\end{array}$ & $\begin{array}{l}\text { Lab } \\
= \\
= \\
=\end{array}$ & $\begin{array}{l}\text { Est. } \\
4.23 \\
0.01 \\
0.04\end{array}$ & $\begin{array}{l}\text { Rel. } \\
B R \\
S A \\
S B\end{array}$ & $\begin{array}{l}\text { Error } \\
(95 \%) \\
(95 \%) \\
(95 \%)\end{array}$ & $\begin{array}{l}= \\
= \\
= \\
=\end{array}$ \\
\hline
\end{tabular}




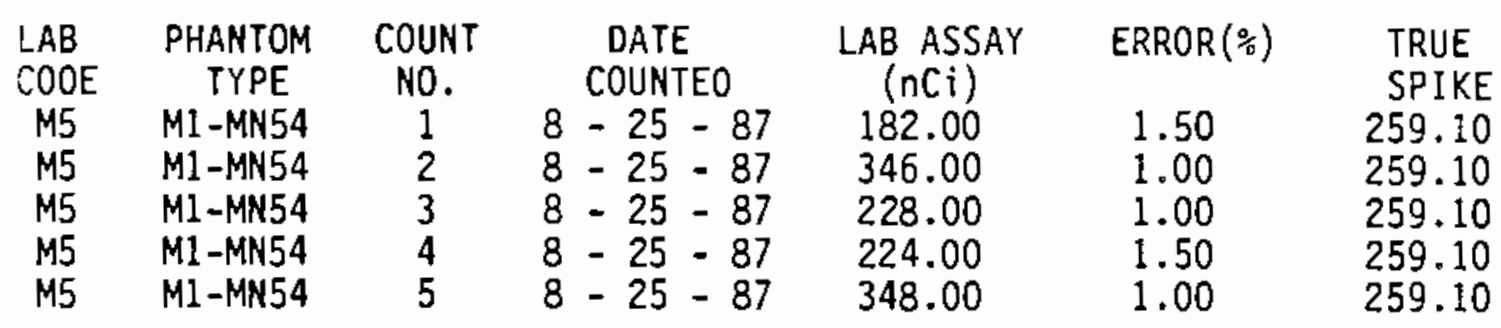

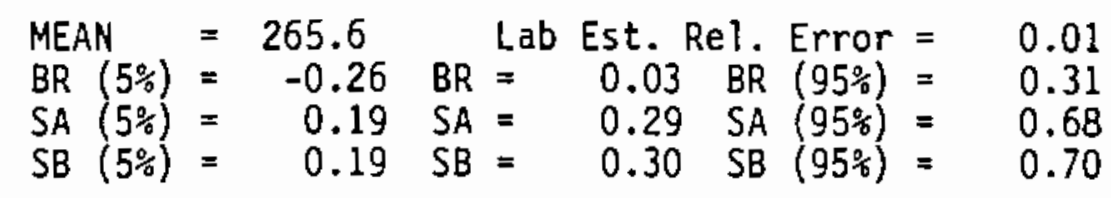

$\begin{array}{ccccccc}\text { LAB } & \text { PHANTOM } & \text { COUNT } & \text { OATE } & \text { LAB ASSAY } & \text { ERROR(\%) } & \text { TRUE } \\ \text { CO0E } & \text { TYPE } & \text { N0. } & \text { COUNTE0 } & \text { (nCi) } & & \text { SPIKE } \\ \text { M6 } & \text { M2-CE144 } & 1 & 8-20-87 & 97.00 & 20.50 & 80.40 \\ \text { M6 } & \text { M2-CE144 } & 2 & 8-20-87 & 60.00 & 26.00 & 80.40 \\ \text { M6 } & \text { M2-CE144 } & 3 & 8-20-87 & 136.00 & 10.55 & 80.40\end{array}$

$\begin{array}{lllll}\text { MEAN } & =97.7 & \text { Lab Est. Rel. Error }= & 0.19 \\ \text { BR }(5 \%)= & -0.58 \text { BR }=0.21 \text { BR }(95 \%)= & 1.01 \\ \text { SA }(5 \%)= & 0.22 & \text { SA }= & 0.39 \text { SA }(95 \%)= & 1.71 \\ \text { SB }(5 \%)= & 0.27 & \text { SB }= & 0.47 \text { SB }(95 \%)= & 2.08\end{array}$

\begin{tabular}{|c|c|c|c|c|c|c|c|}
\hline $\begin{array}{l}\angle A B \\
\text { CODE } \\
M 6 \\
M 6 \\
M 6 \\
M 6 \\
M 6\end{array}$ & $\begin{array}{l}\text { PHANTOM } \\
\text { TYPE } \\
\text { M1-CE144 } \\
\text { M1-CE144 } \\
\text { M1-CE144 } \\
\text { M1-CE144 } \\
\text { M1-CE144 }\end{array}$ & $\begin{array}{c}\text { COUNT } \\
\text { NO. } \\
1 \\
2 \\
3 \\
4 \\
5\end{array}$ & $\begin{array}{l} \\
8 \\
8 \\
8 \\
8 \\
8\end{array}$ & $\begin{array}{l}\text { DATE } \\
\text { COUNTED } \\
=20-87 \\
=20-87 \\
=20-87 \\
-20-87 \\
-20-87\end{array}$ & $\begin{array}{c}\text { LAB ASSAY } \\
(n C j) \\
515.00 \\
484.00 \\
450.00 \\
455.00 \\
535.00\end{array}$ & $\begin{array}{l}5.50 \\
6.00 \\
6.00 \\
6.00 \\
5.50\end{array}$ & $\begin{array}{r}\text { TRUE } \\
\text { SPIKE } \\
693.56 \\
693.56 \\
693.56 \\
693.56 \\
693.56\end{array}$ \\
\hline
\end{tabular}

\begin{tabular}{|c|c|c|c|c|c|c|c|c|}
\hline $\begin{array}{l}\text { MEAN } \\
\text { BR }(5 \%) \\
\text { SA }(5 \%) \\
\text { SB }(5 \%)\end{array}$ & $\begin{array}{l}= \\
= \\
=\end{array}$ & $\begin{array}{r}487.8 \\
-0.35 \\
0.05 \\
0.03\end{array}$ & $\begin{array}{l}\text { BR } \\
\text { SA } \\
\text { SB }\end{array}$ & $\begin{array}{l}\text { Lab } \\
= \\
= \\
=\end{array}$ & $\begin{array}{r}\text { Est. } \\
-0.30 \\
0.08 \\
0.05\end{array}$ & $\begin{array}{l}\text { Rel } \\
\text { BR } \\
\text { SA } \\
\text { SB }\end{array}$ & $\begin{array}{l}\text { Error } \\
(95 \%) \\
(95 \%) \\
(95 \%)\end{array}$ & \\
\hline
\end{tabular}

$\begin{array}{lcccccc}\text { LAB } & \text { PHANTOM } & \text { COUNT } & \text { DATE } & \text { LAB ASSAY } & \text { ERROR }(\%) & \text { TRUE } \\ \text { CODE } & \text { TYPE } & \text { N0. } & \text { COUNTED } & (\text { nCi }) & & \text { SPIKE } \\ \text { M6 } & \text { M2-MN54 } & 1 & 8-20-87 & 124.00 & 2.00 & 25.79 \\ \text { M6 } & \text { M2-MN54 } & 2 & 8-20-87 & 122.00 & 2.00 & 25.79 \\ \text { M6 } & \text { M2-MN54 } & 3 & 8-20-87 & 124.00 & 2.00 & 25.79 \\ \text { M6 } & \text { M2-MN54 } & 4 & 8-20-87 & 122.00 & 2.00 & 25.79 \\ \text { M6 } & \text { M2-MN54 } & 5 & 8-20-87 & 123.00 & 2.00 & 25.79\end{array}$

\begin{tabular}{|c|c|c|c|c|c|c|}
\hline $\begin{array}{l}\text { MEAN } \\
\text { BR (5\%) } \\
\text { SA } \quad(5 \%) \\
\text { SB }(5 \%)\end{array}$ & $\begin{array}{lr}= & 123.0 \\
= & 3.73 \\
= & 0.01 \\
= & 0.03\end{array}$ & $\begin{array}{l}B R \\
S A \\
S B\end{array}$ & $\begin{array}{ll}\text { Lab Est. } \\
=\quad 3.77 \\
=\quad 0.01 \\
=\quad 0.04\end{array}$ & $\begin{array}{l}\mathrm{Rel} \\
\mathrm{BR} \\
\mathrm{SA} \\
\mathrm{SB}\end{array}$ & $\begin{array}{l}\text { Error } \\
(95 \%) \\
(95 \%) \\
(95 \%)\end{array}$ & \\
\hline
\end{tabular}




\begin{tabular}{|c|c|c|c|c|c|c|c|}
\hline $\begin{array}{l}\text { LAB } \\
\text { CODE } \\
\text { M6 } \\
\text { M6 } \\
\text { M6 } \\
\text { M6 } \\
\text { M6 }\end{array}$ & $\begin{array}{c}\text { PHANTOM } \\
\text { TYPE } \\
\text { M1-MN54 } \\
\text { M1-MN54 } \\
\text { M1-MN54 } \\
\text { M1-MN54 } \\
\text { M1-MN54 }\end{array}$ & $\begin{array}{c}\text { COUNT } \\
\text { NO. } \\
1 \\
2 \\
3 \\
4 \\
5\end{array}$ & $\begin{array}{l} \\
8 \\
8 \\
8 \\
8 \\
8\end{array}$ & $\begin{array}{l}\text { DATE } \\
\text { COUNTED } \\
\begin{aligned} 20-87 \\
20-87 \\
20-87 \\
20-87 \\
20-87 \\
20-87\end{aligned}\end{array}$ & $\begin{array}{c}\text { LAB ASSAY } \\
(\mathrm{nCi}) \\
328.00 \\
332.00 \\
324.00 \\
337.00 \\
330.00\end{array}$ & $\begin{array}{l}1.00 \\
1.00 \\
1.00 \\
1.00 \\
1.00\end{array}$ & $\begin{array}{l}\text { TRUE } \\
\text { SPIKE } \\
261.99 \\
261.99 \\
261.99 \\
261.99 \\
261.99\end{array}$ \\
\hline
\end{tabular}

MEAN $=330.2 \quad$ Lab Est. Rel. Error $=00.01$
BR (5\%) $=0.24$ BR $=0.26$ BR $(95 \%)=0.28$
SA (5\%) $=0.01$ SA $=0.01$ SA $(95 \%)=0.03$
SB $(5 \%)=0.01$ SB $=0.02$ SB $(95 \%)=0.04$

$\begin{array}{lcccccc}\text { LAB } & \text { PHANTOM } & \text { COUNT } & \text { OATE } & \text { LAB ASSAY } & \text { ERROR }(\%) & \text { TRUE } \\ \text { CO0E } & \text { TYPE } & \text { N0. } & \text { COUNTE0 } & (n C i) & & \text { SPIKE } \\ \text { M7 } & \text { M2-CE144 } & 1 & 8-20-87 & 77.00 & 25.50 & 80.40 \\ \text { M7 } & \text { M2-CE144 } & 2 & 8-20-87 & 70.00 & 27.50 & 80.40 \\ \text { M7 } & \text { M2-CE144 } & 3 & 8-20-87 & 39.00 & 39.50 & 80.40 \\ \text { M7 } & \text { M2-CE144 } & 4 & 8-20-87 & 66.00 & 29.50 & 80.40\end{array}$

MEAN $=63.0 \quad$ Lab Est. Rel. Error $=0.31$
BR (5\%) $=-0.46$ BR $=-0.22$ BR $(95 \%)=0.03$
SA (5\%) $=0.16$ SA $=0.26$ SA $(95 \%)=0.77$
SB $(5 \%)=0.13$ SB $=0.21$ SB $(95 \%)=0.60$

\begin{tabular}{lcccccr} 
LAB & PHANTOM & COUNT & OATE & LAB ASSAY & ERROR(\%) & \multicolumn{1}{c}{ TRUE } \\
CODE & TYPE & NO. & COUNTE0 & $\begin{array}{c}\text { (nCi) } \\
\text { SPIKE }\end{array}$ & & 693.56 \\
M7 & M1-CE144 & 1 & $8-20-87$ & 621.00 & 6.50 & 693.56 \\
M7 & M1-CE144 & 2 & $8-20-87$ & 719.00 & 5.50 & 693.56 \\
M7 & M1-CE144 & 3 & $8-20-87$ & 594.00 & 7.50 & 693.56 \\
M7 & M1-CE144 & 4 & $8-20-87$ & 603.00 & 7.00 & 693.56 \\
M7 & M1-CE144 & 5 & $8-20-87$ & 737.00 & 6.00 & 693.56
\end{tabular}

$\begin{array}{lllll}\text { MEAN } & =654.8 & \text { Lab Est. Re l. Error }= & 0.07 \\ \text { BR }(5 \%)= & -0.15 \text { BR }= & -0.06 \text { BR }(95 \%)= & 0.04 \\ \text { SA }(5 \%)= & 0.07 \text { SA }= & 0.10 \text { SA }(95 \%) & =0.25 \\ \text { SB }(5 \%)= & 0.06 \text { SB }=0.10 \text { SB }(95 \%)= & 0.23\end{array}$

$\begin{array}{lcccccc}\text { LAB } & \text { PHANTOM } & \text { COUNT } & \text { OATE } & \text { LAB ASSAY } & \text { ERROR } \% \text { \% } & \text { TRUE } \\ \text { CODE } & \text { TYPE } & \text { N0. } & \text { COUNTED } & (\mathrm{nCi}) & & \text { SPIKE } \\ \text { M7 } & \text { M2-MN54 } & 1 & 8-20-87 & 129.00 & 2.00 & 25.79 \\ \text { M7 } & \text { M2-MN54 } & 2 & 8-20-87 & 122.00 & 2.00 & 25.79 \\ \text { M7 } & \text { M2-MN54 } & 3 & 8-20-87 & 123.00 & 2.50 & 25.79 \\ \text { M7 } & \text { M2-MN54 } & 4 & 8-20-87 & 127.00 & 2.00 & 25.79 \\ \text { M7 } & \text { M2-MN54 } & 5 & 8-20-87 & 124.00 & 2.00 & 25.79\end{array}$

$\begin{array}{lllll}\text { MEAN } & =125.0 & \text { Lab Est. Re 1. Error }= & 0.02 \\ \mathrm{BR}(5 \%) & =3.74 & \mathrm{BR}= & 3.85 \mathrm{BR}(95 \%)= & 3.95 \\ \mathrm{SA}(5 \%) & =0.02 & \mathrm{SA}= & 0.02 \mathrm{SA}(95 \%)= & =0.06 \\ \mathrm{SB}(5 \%) & =0.07 \mathrm{SB}= & 0.11 \mathrm{SB}(95 \%)= & 0.27\end{array}$




\begin{tabular}{lcccccr} 
LAB & PHANTOM & COUNT & DATE & LAB ASSAY & ERROR(\%) & \multicolumn{1}{c}{ TRUE } \\
CODE & TYPE & NO. & COUNTED & $(\mathrm{nCi})$ & & SPIKE \\
M7 & M1-MN54 & 1 & $8-20-87$ & 346.00 & 1.50 & 261.99 \\
M7 & M1-MN54 & 2 & $8-20-87$ & 355.00 & 1.00 & 261.99 \\
M7 & M1-MN54 & 3 & $8-20-87$ & 351.00 & 1.00 & 261.99 \\
M7 & M1-MN54 & 4 & $8-20-87$ & 352.00 & 1.00 & 261.99 \\
M7 & M1-MN54 & 5 & $8-20-87$ & 354.00 & 1.00 & 261.99
\end{tabular}

\begin{tabular}{|c|c|c|c|c|c|c|c|c|}
\hline $\begin{array}{l}\text { MEAN } \\
\text { BR }(5 \%) \\
\text { SA }(5 \%) \\
\text { SB }(5 \%)\end{array}$ & $\begin{array}{l}= \\
= \\
= \\
=\end{array}$ & $\begin{array}{r}351.6 \\
0.33 \\
0.01 \\
0.01\end{array}$ & $\begin{array}{l}\text { BR } \\
\text { SA } \\
\text { SB }\end{array}$ & $\begin{array}{l}\text { Lab } \\
= \\
= \\
=\end{array}$ & $\begin{array}{l}\text { Est. } \\
0.34 \\
0.01 \\
0.01\end{array}$ & $\begin{array}{l}\text { Rel. } \\
\text { BP } \\
\text { SA } \\
\text { SB }\end{array}$ & $\begin{array}{l}\text { Error } \\
(95 \%) \\
(95 \%) \\
(95 \%)\end{array}$ & \\
\hline
\end{tabular}

$\begin{array}{lcccccc}\text { LAB } & \text { PHANTOM } & \text { COUNT } & \text { DATE } & \text { LAB ASSAY } & \text { ERROR(\%) } & \text { TRUE } \\ \text { CODE } & \text { TYPE } & \text { NO. } & \text { COUNTED } & \text { (nCi) } & & \text { SPIKE } \\ N & \text { P2-PU238 } & 1 & 3-30-89 & 23.00 & 35.00 & 31.82 \\ N & \text { P2-PU238 } & 2 & 3-30-89 & 29.00 & 31.00 & 31.82 \\ N & \text { P2-PU238 } & 3 & 3-30-89 & 23.00 & 35.00 & 31.82 \\ N & \text { P2-PU238 } & 4 & 3-30-89 & 43.00 & 21.00 & 31.82 \\ N & \text { P2-PU238 } & 5 & 3-30-89 & 27.00 & 30.00 & 31.82\end{array}$

\begin{tabular}{|c|c|c|c|c|c|c|c|c|}
\hline $\begin{array}{l}\text { MEAN } \\
\text { BR }(5 \%) \\
\text { SA }(5 \%) \\
\text { SB }(5 \%)\end{array}$ & & $\begin{array}{r}29.0 \\
-0.34 \\
0.18 \\
0.17\end{array}$ & $\begin{array}{l}B R \\
S A \\
S B\end{array}$ & $\begin{array}{l}\text { Lab } \\
= \\
= \\
=\end{array}$ & $\begin{array}{l}\text { Est. } \\
-0.09 \\
0.28 \\
0.26\end{array}$ & $\begin{array}{l}\text { Rel. } \\
\text { BA } \\
\text { SA } \\
\text { SE }\end{array}$ & $\begin{array}{l}\text { Error } \\
(95 \%) \\
(95 \%) \\
(95 \%)\end{array}$ & \\
\hline
\end{tabular}

$\begin{array}{lcccccc}\text { LAB } & \text { PHANTOM } & \text { COUNT } & \text { DATE } & \text { LAB ASSAY } & \text { ERROR(\%) } & \text { TRUE } \\ \text { CODE } & \text { TYPE } & \text { NO. } & \text { COUNTED } & \begin{array}{c}\text { (nCi) } \\ \text { SPIKE }\end{array} & & \\ N & \text { P3-PU238 } & 1 & 3-19-89 & 398.00 & 12.00 & 366.31 \\ N & \text { P3-PU238 } & 2 & 3-19-89 & 375.00 & 11.00 & 366.31 \\ N & \text { P3-PU238 } & 3 & 3-19-89 & 391.00 & 12.00 & 366.31 \\ N & \text { P3-PU238 } & 4 & 3-19-89 & 366.00 & 12.00 & 366.31 \\ N & \text { P3-PU238 } & 5 & 3-19-89 & 350.00 & 12.00 & 366.31\end{array}$

\begin{tabular}{|c|c|c|c|c|c|c|c|c|}
\hline $\begin{array}{l}\text { MEAN } \\
\text { BR }(5 \%) \\
\text { SA } \quad(5 \%) \\
\text { SB } \quad(5 \%)\end{array}$ & $\begin{array}{l}= \\
= \\
= \\
=\end{array}$ & $\begin{array}{r}376.0 \\
-0.02 \\
0.03 \\
0.03\end{array}$ & $\begin{array}{l}B R \\
S A \\
S B\end{array}$ & $\begin{array}{l}\text { Lab } \\
= \\
= \\
=\end{array}$ & $\begin{array}{l}\text { Est. } \\
0.03 \\
0.05 \\
0.05\end{array}$ & $\begin{array}{ll}\operatorname{Re} 1 . \\
5 \\
5 \\
5 \\
5 A \\
S B\end{array}$ & $\begin{array}{l}\text { Error } \\
(95 \%) \\
(95 \%) \\
(95 \%)\end{array}$ & \\
\hline
\end{tabular}

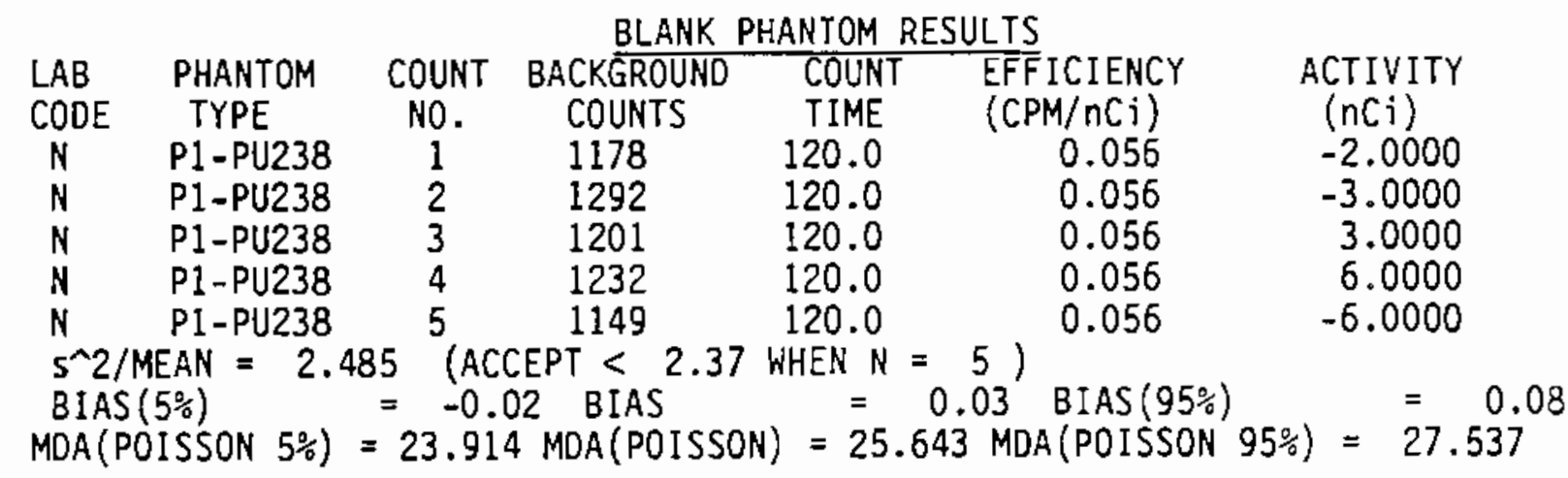


PNL -7307

UC -607

\section{DISTRIBUTION}

No. of

Copies

OFFSITE

12 DOE/Office of Scientific and Technical Information

DOE Headquarters

R. W. Barber Office of Safety Compliance Division of Compliance Programs

U.S. Department of Energy, EH-34

Washington, DC 20545

C. M. Borgstrom Office of NEPA Project Assistance

U.S. Department of Energy, $\mathrm{EH}-25$

Washington, DC 20545

R. Bowser Office of Quality Programs

U.S. Department of Energy, EH-322

washington, DC 20545

E. Branagan Office of Safety Appraisals Division of Nuclear Safety Technology

U.S. Department of Energy, EH-332

Washington, DC 20545
No. of

Copies
K. P. Ferlic

Operational Standards \& Analysis

Office of Safety Policy and and Standards

U.S. Department of Energy

Washington, DC 20545

J. E. Fitzgerald, Jr. Office of Safety Policy and Standards

U.S. Department of Energy, EH-35

Washington, DC 20545

R. E. Jones

Office of Safety Policy and Standards

U.S. Department of Energy, EH-352

Washington, DC 20545

J. P. Knight, Acting Director Office of Safety Appraisals

U.S. Department of Energy, EH-32

Washington, DC 20545

R. M. Loesch

Operational Standards and Analysis Division

Office of Safety Policy and Standards

EH-352

U.S. Department of Energy

Washington, DC 20545 
No. of

Copies

D. R. Nelson

Office of Safety Policy and Standards,

EH-352

U.S. Department of Energy

Washington, DC 20545

H. J. Pettengill, Director

Division of Nuclear Safety

Technology

EH-35

U.S. Department of Energy

Washington, DC 20545

D. M. Rohrer

Office of Safety Policy and Standards

EH-352

U.S. Department of Energy

Washington, DC 20545

R. S. Scott

Office of Environmental Audit

U.S. Department of Energy, EH-24

Washington, DC 20545

F. Tooper

Office of Safety Policy and Standards

Division of Operational Standards and Analysis

U.S. Department of Energy, EG-352

Washington, DC 20545
No. of

Copies

DOE Albuquerque Operations

Office

Manager, Health Physics

Pantex Plant

Mason \& Hanger--Silas Mason

Co., Inc.

P.0. Box 30020

Amarillo, TX 79177

H. D. Burnett

OE Sandia National

Laboratories

Mail Code 3312, Bldg. 8619

P.0. Box 2800

Albuquerque, NM 87115

J. W. Doty

Mound Laboratory

Monsanto Research Corporation

P.0. Box 32

Miamisburg, $\mathrm{OH} 45342$

J. Graff

Los Alamos National

Laboratory, MS E584

P.0. Box 1663

Los Alamos, NM 87545

G. Runckels

U.S. Department of Energy

Albuquerque Operations Office P.0. Box 5400

Albuquerque, NM 87115 
No. of

Copies

DOE Chicago Operations Office

L. V. Coulson

Fenmi National Accelerator Laboratory

P.0. Box 500

Batavia, IL 60510

E. Jascewsky

U.S. Department of Energy Chicago Operations Office

9800 S. Cass Ave.

Argonne, IL 60439

Manager, Health Physics

Radiological Sciences

Division, Bldg. 703M

Brookhaven National

Laboratory

Upton, NY 11973

D. Toohey

Argonne National Laboratory 9800 S. Cass Ave.

Argonne, IL 60439

DOE Idaho Operations Office

J. Martin

U.S. Department of Energy

Idaho Operations Office

785 DOE Place

Idaho Falls, ID 83402

B. L. Rich

EG\&G Idaho

P.0. Box 1625

Idaho Falls, ID 83401

A. N. Tschaeche

WINCO

MS 5209

P.0. Box 4000

Idaho Falls, ID 83403
No. of

Copies

DOE Nevada Operations Office

A. E. Bicker

Reynolds Electrical \&

Engineering $\mathrm{Co}$. , Inc.

P.0. Box 14400

Las Vegas, NV 89114

M. Marreli

U.S. Department of Energy

Nevada Operations Office

P.0. Box 14100

Las Vegas, NV 89114

DOE Oak Ridge Operations

office

R. J. Cloutier

Oak Ridge Associated

Universities

P.0. Box 117

0ak Ridge, TN 37831-0117

R. E. Halliburton

Oak Ridge Nationa] Laboratory

P.0. Box X

Oak Ridge, TN 38731

S. L. Hinnefeld

Westinghouse Materials Co. of Ohio

P.0. Box 398704

Cincinnati, OH 45239

T. M. Jelinek

U.S. Department of Energy

Oak Ridge Operations Office

P.0. Box E

Oak Ridge, TN 37831

J. B. Hunt

Bldg. 9711-1

P.0. Box 2009

0ak Ridge, TN 37831-8105 
No. of

Copies

D. C. Parzyck

Oak Ridge National Laboratory P.0. Box 2008

Oak Ridge, TN 37831-6103

S. F. Seltzer

Paducah Gaseous Diffusion Plant

P.0. Box 1410

Paducah, KY 42001

F. G. Van Loocke

RMI Company

P.0. Box 579

Ashtabula, $\mathrm{OH} \quad 44004$

E. R. Wagner

Portsmouth Gaseous Diffusion Plant

Martin Marietta Energy Systems

P.0. Box 628

Piketon, $\mathrm{OH} 45661$

H. D. Whitehead

Oak Ridge Gaseous Diffusion Plant

P. 0. Box 2003

0ak Ridge, TN 37831-7403

DOE San Francisco Operations Office

G. W. Campbe11

Lawrence Livermore National Laboratory

P.0. Box 808, MSL382

Livermore, CA 94550

T. R. Crites

Lawrence Livermore National Laboratory, L-382

P.0. Box B08

Livermore, CA 94550
No. of

Copies

W. Warner

U.S. Department of Energy

San Francisco Operations

Office

1333 Broadway

0akland, CA 94612

R. C. McCall

Stanford Linear Accelerator

P.0. Box 4349

Stanford, CA 94305

R. G. Thomas

Lawrence Berkeley Laboratory

1 Cyclotron Road

Berkeley, CA 94720

G. Warren

Stanford Linear Accelerator

P.0. Box 4349

Stanford, CA 94305

DOE Savannah River Operations office

W. T. Thornton

U.S. Department of Energy

Savannah River Operations Office

P.0. Box A

Aiken, SC 29801

R. M. Hall, Jr.

E. I. duPont de Nemours, Inc.

Savannah River Plant

Aiken, SC 29801

W. C. Reinig

E. I. duPont de Nemours \& Co. Savannah River Plant

Aiken, SC 29801 
No. of

Copies

EPA Office of Radiation Programs

A. Richardson

U.S. Environmental Protection Agency, ANR -460

401 M Street, SW

Washington, DC 20460

National Center for Devices

and Radiological Health

J. C. Villforth

FDA Bureau of Radiological Health

Rockville, MD 20852

National Institute of

Standards and Technology

K. Innes

National Institute of

Standards and Technology

Bldg 245, Rm. C229

Gaithersburg, MD 20899

Nuclear Regulatory Commission

A. K. Roecklein

U.S. Nuclear Regulatory Commission

Washington, DC 20555
No. of

Copies

ONSITE

2 DOE Richland Operations

office

D. T. Evans

P. H. Kruger

91 Pacific Northwest Laboratory

D. E. Bihl

L. G. Faust

D. R. Fisher

D. M. Fleming

D. P. Higby

J. R. Johnson

J. A. MacLellan (10)

J. B. Martin

J. C. McDonald

P. C. 0lsen (30)

H. E. Palmer (3)

J. M. Selby (20)

K. L. Soldat

P. S. Stansbury

K. L. Swinth

R. J. Traub (10)

Health Physics Department Library

Publishing Coordination (1)

Technical Report Files (5) 
